SERGIO ZAHR FILHO

\title{
PENHORA: EXAME DA TÉCNICA PROCESSUAL À LUZ DA REALIDADE ECONÔMICA E SOCIAL
}

Dissertação submetida à Faculdade de Direito da Universidade de São Paulo como requisito parcial à obtenção do grau de Mestre em Direito, sob orientação do Professor Associado Flávio Luiz Yarshell.

Faculdade de Direito da Universidade de São Paulo

São Paulo

2009 
SERGIO ZAHR FILHO

\section{PENHORA: EXAME DA TÉCNICA PROCESSUAL À LUZ DA REALIDADE ECONÔMICA E SOCIAL}

Dissertação submetida à Faculdade de Direito da Universidade de São Paulo como requisito parcial à obtenção do grau de Mestre em Direito, sob orientação do Professor Associado Flávio Luiz Yarshell.

Faculdade de Direito da Universidade de São Paulo São Paulo

2009 
SERGIO ZAHR FILHO

PENHORA: EXAME DA TÉCNICA PROCESSUAL À LUZ DA REALIDADE ECONÔMICA E SOCIAL 


\section{RESUMO}

O sistema de execução forçada é o instrumento previsto no Código de Processo Civil Brasileiro destinado a satisfazer o credor de obrigações pecuniárias contidas em sentenças ou em títulos executivos extrajudiciais. Trata-se de sistema cujo bom funcionamento não só interessa às partes de um litígio, mas a toda sociedade, em função de suas importantes repercussões sociais e econômicas. Por meio da execução forçada o Juiz invade o patrimônio do devedor, independentemente da vontade deste, e expropria bens em benefício do credor. Para o adequado funcionamento da execução forçada é essencial que o ato processual de penhora de bens do devedor seja efetivo. A penhora consiste em apreender e afetar juridicamente bens do devedor, os quais ficam vinculados ao Juízo da execução até o momento próprio de realização da expropriação dos bens. A penhora é ato processual que incide sobre a realidade econômica e social e padece de suas contingências. O objetivo desta dissertação de Mestrado é investigar a relação entre o ato de penhora e seu objeto, a partir da premissa de que o método ou a forma de apreensão judicial deve estar plenamente adaptado aos atributos sociais, jurídicos e econômicos do bem que se pretende apreender. Nesse contexto, será investigado o regime da penhora do Código de Processo Civil Brasileiro, bem como serão estudados os tipos de penhora de bens de significação econômica mais importante na realidade atual. 


\begin{abstract}
The system of "forced execution" is the instrument set forth in the Brazilian Code of Civil Procedure destined to satisfy the creditor of pecuniary obligations contained in judgments or in extrajudicial execution instruments. It is a system, the good functioning of which is of interest not only to the parties in a litigation, but also to society as a whole, in view of its important social and economic repercussions. The Judge, by means of the "forced execution", invades the debtor's assets, irrespective of the will of the latter, and expropriates assets to the benefit of the creditor. For the proper functioning of the "forced execution", it is essential that the procedural act of levy of the debtor's assets be effective. The levy consists of seizing and legally affecting the debtor's assets, which become bound to the Court of the execution until the specific time of performance of the expropriation of the assets. The levy is a procedural act which applies to economic and social reality, and lacks its contingencies. The objective of this Master's dissertation is to investigate the relationship between the act of levy and its object, starting from the premise that the method or the form of judicial seizure must be fully adapted to the social, juridical and economic attributes of the asset which is intended to be seized. In this context, the regime of levy in the Brazilian Code of Civil Procedure will be investigated, as well studying the types of levy of assets of the most important economic significance in the current reality.
\end{abstract}




\section{AGRADECIMENTOS}

Agradeço aos meus pais que fizeram esta jornada intelectual possível.

Agradeço à Fernanda. Com muita paciência e carinho, ficou ao meu lado durante este longo período de estudos que roubou muitos dos nossos fins de semana.

Agradeço ao Professor Flávio Luiz Yarshell que confiou em mim, abrindo esta porta no curso de Pós-Graduação da USP, bem como me deu valorosos conselhos.

Agradeço aos meus sócios no escritório que certamente direta ou indiretamente contribuíram nesta empreitada. Agradeço especialmente à equipe do contencioso, André, Raquel, Juliana, Bruna e Thiago, com quem pude contar nos meus períodos de ausência.

Agradeço a Hugo Cavaguti que me ajudou na realização da pesquisa de jurisprudência.

Por fim, não poderia deixar de lembrar de Vanderlei Arcanjo da Silva, amigo de curto período, com quem comecei os estudos e atividades da Pós, mas que, pelos infortúnios da vida, nos deixou cedo. Fica seu exemplo de amizade, dedicação e superação. 
"É assim que a tarefa dos processualistas cresceu enormemente. Já nos consideramos os sacerdotes de uma ciência - ou de uma arte neutra. Hoje sabemos que a história e a ciência política, a economia, chegaram a ser ingredientes necessários do nosso trabalho". (Mauro Cappelletti) 


\section{SUMÁRIO}

1. INTRODUÇÃO

2. O SISTEMA DE EXECUÇÃO FORÇADA

2.1. A jurisdição e seus escopos 14

2.2. A tutela jurisdicional e suas espécies 19

2.3. A tutela jurisdicional executiva (satisfativa) 22

2.4. A Execução Forçada 28

2.5. Os escopos da Execução Forçada 29

2.6. Execução Forçada e Economia 31

2.6.1. Delimitação da análise 31

2.6.2. Os custos de transação 33

2.6.3. O papel das instituições $\quad 37$

2.6.4. Execução Forçada: uma análise crítica $\quad 41$

2.6.5. Um exemplo: o spread bancário 46

2.6.6. Execução Forçada e Economia: conclusão 49

\section{A PENHORA}

3.1. Breve análise histórica $\quad 52$

3.2. Responsabilidade patrimonial 64

3.3. O conceito e a função da penhora $\quad 67$

3.4. O objeto da penhora $\quad 70$

3.4.1. Objeto da penhora e tipicidade legal 73

$\begin{array}{ll}\text { 3.4.2. Objeto da penhora e método de apreensão } & 77\end{array}$

3.4.2.1. A penhora de bens corpóreos $\quad 80$

3.4.2.2. A penhora de bens incorpóreos $\quad 82$

3.5. Efeitos da penhora $\quad 87$

3.5.1. Efeitos sobre o poder de disposição $\quad 89$

3.5.2. Efeitos sobre a posse do bem e poderes correlatos 91

3.6. Formalização da penhora 95 
3.7. A penhora e a técnica coercitiva

3.7.1. O caráter coercitivo do regime dos atos atentatórios à dignidade da justiça

$\begin{array}{ll} & 105 \\ \text { 3.7.2. A prisão do depositário infiel } & 108\end{array}$

4. TIPOS DE PENHORA

4.1. Penhora na realidade econômica e social atual 118

4.2. Penhora de dinheiro 122

4.2.1. O dinheiro 122

4.2.2. Modo de apreensão 124

4.2.3. Efeitos 128

4.3. Penhora de aplicação em instituição financeira 129

4.3.1. A aplicação em instituição financeira 129

4.3.2. Modo de apreensão 131

4.3.3. Efeitos 138

4.4. Penhora de títulos e valores mobiliários com cotação em mercado 139

4.4.1. Os valores mobiliários 139

4.4.2. Modo de apreensão 143

4.4.3. Efeitos 146

4.5. Penhora de títulos da dívida pública com cotação em mercado 148

4.5.1. Os títulos da dívida pública 148

4.5.2. Modo de apreensão 150

4.5.3. Efeitos 151

4.6. Penhora de créditos 151

4.6.1. O crédito 151

4.6.2. Modo de apreensão 152

4.6.3. Efeitos 153

4.7. Penhora de ações e quotas de sociedades empresárias 154

4.7.1. As ações e as quotas de sociedades empresárias 154

4.7.2. Modo de apreensão 159

$\begin{array}{ll}\text { 4.7.3. Efeitos } & 160\end{array}$ 
4.8. Penhora de imóvel 161

4.8.1. O imóvel 161

4.8.2. Modo de apreensão 162

4.8.3. Efeitos 165

4.9. Penhora de percentual de faturamento 166

4.9.1. O faturamento 166

4.9.2. Modo de apreensão 169

4.9.3. Efeitos 175

4.10. Penhora de empresa e de estabelecimento comercial 176

4.10.1. A empresa e o estabelecimento comercial 176

$\begin{array}{ll}\text { 4.10.2. Modo de apreensão } & 178\end{array}$

$\begin{array}{ll}\text { 4.10.3. Efeitos } & 179\end{array}$

5. CONCLUSÃO 180

6. REFERÊNCIAS BIBLIOGRÁFICAS 186

7. OUTRAS FONTES DE PESQUISA 195 


\section{INTRODUÇÃO}

Nos casos em que o devedor não cumpre espontaneamente sua obrigação, o processo só será efetivo se a atividade executiva jurisdicional for bem sucedida, ocorra ela em um processo autônomo de execução ou na própria ação de conhecimento. ${ }^{1}$ Nesse sentido, a execução é fundamental para que a atuação da vontade concreta da Lei se torne plena, satisfazendo os interesses do credor e encerrando definitivamente o conflito perante o Poder Judiciário.

No que se refere às obrigações de pagamento de quantia, "na tradição do sistema brasileiro, a satisfação do credor de quantia se dá, por regra, mediante execução por expropriação, isto é, execução em seu sentido clássico de atuação da sanção secundária, com invasão da esfera patrimonial do devedor para, contra sua vontade, satisfazerse o credor ('execução forçada')."2

A execução forçada tem seu divisor de águas na penhora. Caso esta atinja seu intento de propiciar a apreensão de bens do devedor condizentes com o valor do crédito, a execução tende a satisfazer o credor, cumprindo adequadamente seu papel de atuar concretamente o direito material. Do contrário, caso a penhora não se efetive, a execução está fadada ao fracasso e as normas de direito material não produzirão os efeitos que delas se esperam.

\footnotetext{
${ }^{1}$ Com a edição da Lei n. 11.232 de 22/12/2005 foi abolido o processo autonômo de execução para as sentenças, as quais passam a ser executadas no mesmo processo em que proferidas, em fase que se passou a denominar de "cumprimento". Conforme já ensinava Kazuo Watanabe antes da edição da nova Lei: "O binômio "cogniçãoexecução' continua a ser utilizado pelos doutrinadores para explicar a natureza da atividade do juiz e a utilidade e o alcance dos provimentos diferenciados. Uma coisa, porém, é o binômio 'cognição-execução' e outra dicotomia "processo de cognição" (ou de conhecimento) - processo de execução. As atividades de cognição e execução podem estar aglutinadas num mesmo processo, como ocorre na ação executiva lato sensu e na ação mandamental [...]". (cf. Da cognição no processo civil, p. 53)

2 cf. Flávio Luiz Yarshell ("Tutela mandamental nas obrigações de pagamento de quantia" in Revista da Procuradoria Geral do Estado de São Paulo, n. especial, pág. 274, 2003).
} 
A penhora pode não se realizar por absoluta falta de patrimônio do devedor, o que pode decorrer da real condição do devedor, ou também pela prática de atos fraudulentos pelo devedor, nem sempre desvendáveis, de modo a que se possa fazer valer os remédios disponíveis no ordenamento jurídico para desconstituição da fraude. Há ainda uma outra hipótese a obstar a realização da penhora representada pela dificuldade de se localizar bens em nome do devedor e apreendê-los a tempo, antes que uma fraude no curso da execução se opere.

Como primeiro ato expropriatório da execução que, portanto, se projeta para fora do processo, incidindo sobre bens em circulação na economia, a penhora é ato que necessariamente confronta a realidade, ${ }^{3}$ advindo daí as dificuldades acima mencionadas.

Não é à toa que os operadores do direito, premidos pela realidade, busquem alternativas mais eficazes às espécies de penhora consagradas em Lei e tradicionalmente mais utilizadas, como a penhora de imóveis. O exemplo mais conhecido foi o desenvolvimento e a adoção em nosso sistema da chamada penhora on line, a qual renovou as possibilidades de penhora de dinheiro depositados em instituição financeira. Outro exemplo desta tendência é a penhora do faturamento de empresa, cuja legalidade foi por muito tempo discutida nos Tribunais até que sua utilização fosse acolhida pela jurisprudência e após fosse positivada no Código de Processo Civil por meio da Lei n. 11.382 de 6 de dezembro de 2006.

Trata-se de demonstração inequívoca de como o instituto da penhora sofre influência direta da realidade social e econômica em que atua e de como invariavelmente o ordenamento jurídico positivo fica a reboque das mudanças e do dinamismo da sociedade.

\footnotetext{
${ }^{3}$ Trata-se do primeiro ato de concreção da atividade executiva ou também “...da atividade destinada a tornar realidade a disposição do Estado, anunciada abstratamente na lei, de produzir os resultados práticos determinados pelas normas substanciais". (cf. Cândido Rangel Dinamarco, Execução civil, p.106).
} 
O fato é que a penhora será mais eficaz, na medida em que esteja mais adaptada à realidade econômica e social sobre a qual incide. ${ }^{4}$ Esta constatação, provavelmente válida desde os primórdios da penhora, ganha especial relevo no mundo atual, no qual uma proporção considerável da propriedade e da riqueza econômica vem assumindo novas formas, imateriais, ou mesmo virtuais, um fenômeno de nosso tempo, dominado pela tecnologia digital. Nesse sentido, a penhora, instituto processual antiqüíssimo, cujo arcabouço jurídico foi moldado para atingir bens físicos e corpóreos, deve ser repensada e remodelada à luz desta nova realidade, sob pena de não cumprir sua função processual.

É com este debate que pretendemos colaborar. Faremos isso a partir do estudo do regime jurídico da penhora em confronto com a análise da natureza e atributos jurídicos, sociais e econômicos dos tipos de bens que na realidade atual são potencialmente mais aptos a serem objeto de penhoras mais eficazes.

O faturamento de empresa é um bom exemplo da análise que se pretende empreender. O que é o faturamento de empresa? Trata-se de qualquer receita auferida ou só aquela decorrente da atividade-fim da empresa? De que forma é possível fazer a apreensão e depósito do faturamento como é próprio da penhora? São questões no nosso entender relevantes que podem ser estudadas sob o enfoque do Direito Processual, em busca de uma maior adequação do instrumento processual ao objeto sobre o qual este incide.

Nesse contexto, nosso objetivo é analisar a penhora, o quanto possível, a partir de uma visão que parte do processo, mas que se projeta para fora dele. Nosso foco é estudar a relação do instituto processual com seu objeto e as vicissitudes decorrentes do confronto dos conceitos abstratos do processo com a realidade concreta. É deste confronto que pretendemos extrair caminhos para uma penhora mais adaptada à realidade econômica e social atual e mais eficaz em sua função de alterar esta realidade proporcionando atuação concreta do

\footnotetext{
${ }^{4}$ Segundo Cândido Rangel Dinamarco ao tratar da renovação do Direito Processual em função das mutações da ordem constitucional "é natural que o instrumento se altere e adapte às mutantes necessidades funcionais decorrentes da variação dos objetivos substanciais a perseguir". E em nota a esta afirmação pontua o Professor Dinamarco: "Diz-se em sociologia, que os sistema sociais têm certas 'funções básicas em comum', sendo autorizadamente indicadas quatro: a) manter seus modelos básicos; b) adaptar às condições variáveis;c) integrar suas próprias tarefas e funções; d) atingir os seus próprios objetivos (cfr. Deutsch, Política e governo,p.154). [...]" (cf. A instrumentalidade do processo, p. 33).
} 
direito material, conscientes de que os escopos do processo desbordam da órbita puramente jurídica.

A metodologia é aquela propugnada por Cândido Rangel

Dinamarco:

${ }^{5}$ cf. A instrumentalidade do processo, p. 21-22, 24. 


\section{O SISTEMA DE EXECUÇÃO FORÇADA}

\subsection{A jurisdição e seus escopos}

A afirmação do poder do Estado de criar e dar eficácia às normas jurídicas depende necessariamente do poder estatal de decidir conflitos, por meio de decisões passíveis de imposição a todos que não as cumpram. Trata-se do poder jurisdicional ou da jurisdição, exercida preponderantemente pelo Poder Judiciário. ${ }^{6}$

A jurisdição tem a missão de garantir a aplicabilidade das normas do direito material, de maneira a cumprir sua função primordial de possibilitar a resolução de conflitos sociais. $^{7}$

O escopo fundamental da jurisdição, na aplicação do direito material, é buscar a paz social ${ }^{8}$ com justiça. $^{9}$

\footnotetext{
${ }^{6}$ Nesse sentido: "Pelo que já ficou dito, compreende-se que o Estado moderno exerce o seu poder para a solução de conflitos interindividuais. O poder estatal, hoje, abrange a capacidade de dirimir os conflitos que envolvem as pessoas (inclusive o próprio Estado), decidindo sobre as pretensões apresentadas e impondo as decisões. No estudo da jurisdição, será explicado que esta é uma das expressões do poder estatal, caracterizando-se este como a capacidade, que o Estado tem, de decidir imperativamente e impor decisões. O que distingue a jurisdição das demais funções do Estado (legislação, administração) é precisamente, em primeiro plano, a finalidade pacificadora com que o Estado a exerce". (cf. Cintra, Grinover e Dinamarco, Teoria geral do processo, p. 24).

${ }^{7}$ Conforme ensina Tércio Sampaio Ferraz Jr. o problema central da ciência dogmática do direito na sociedade atual é a decidibilidade de conflitos. E esta ciência "costuma encarar seu objeto, o direito posto e dado previamente, como um conjunto compacto de normas, instituições e decisões que lhe compete sistematizar, interpretar e direcionar, tendo em vista uma tarefa prática de solução de possíveis conflitos que ocorram socialmente. O jurista contemporâneo preocupa-se, assim, com o direito que ele postula ser um todo coerente, relativamente preciso nas suas determinações, orientado para uma ordem finalista, que protege a todos indistintamente". (cf. Introdução ao estudo do direito, p. 83, 88-89).

${ }^{8}$ A lição é de Cândido Rangel Dinamarco: “Por esse aspecto, a função jurisdicional e a legislação estão ligadas pela unidade do escopo fundamental de ambas: a paz social. Mesmo quem postule a distinção funcional muito nítida e marcada entre os dois planos do ordenamento jurídico (teoria dualista) há de aceitar que direito e processo compõem um só sistema voltado à pacificação de conflitos. É uma questão de perspectiva: enquanto a visão jurídica de um e outro em suas relações revela que o processo serve para a atuação do direito, sem inovações ou criação, o enfoque social de ambos os mostra assim solidariamente voltados à mesma ordem de benefícios a serem prestados à sociedade. É sabido e repetido que a vida em sociedade gera insatisfações, mercê de condutas contrárias aos interesses das pessoas e mercê de serem estes literalmente infinitos, enquanto finitos são os bens da vida sobre os quais incidem. Por insatisfações, entenda-se 'um sentimento, um fenômeno psíquico que costuma acompanhar a percepção ou a ameaça de uma carência'. São as insatisfações que justificam toda a
} 
Não é tarefa fácil e também não é nosso objetivo tratar do conceito de "justiça", em razão da alta carga subjetiva que o cerca. Deve-se, entretanto, ao menos mencionar a lição de Tércio Sampaio Ferraz Jr., segundo a qual o sentido de justiça parece permear todas as pessoas e, conseqüentemente, a sociedade que elas compõem. A justiça parece ser assim um atributo que funciona como "princípio doador de sentido para o universo jurídico" ou base de sua legitimidade, sem o que o direito, a despeito de ser válido e vigente, perde o sentido e se torna instrumento de força e arbítrio, causando desorientação aos homens submetidos às suas normas. ${ }^{10}$ Ao distanciar-se de soluções legítimas, que sejam aceitáveis racionalmente pelos homens de uma dada sociedade, o direito distancia-se de sua árdua tarefa de atingir a paz social.

Sendo assim, o escopo da jurisdição de pacificação social não poderia prescindir de uma orientação ao "justo", sob pena de se admitir a aplicação de um direito carente de razoabilidade e racionalidade, fundado apenas na força e no arbítrio.

Pois bem, para atingir seu escopo social de pacificar com justiça, a jurisdição é dotada de um sistema processual, o qual pode ser entendido como a disciplina

atividade jurídica do Estado e é a eliminação delas que lhe confere legitimidade. A vida em sociedade seria bem pior se os estados pessoais de insatisfação fossem todos fadados a se perpetuar em decepções permanentes e inafastáveis; e o Estado, legislando e exercendo a jurisdição, oferece com isso a promessa de pôr fim a esses estados. Eis então que ele define condutas como favoráveis ou desfavoráveis à vida em grupo (licitudes, ilicitudes), acenando com recompensas ou castigos (sanções), além de estabelecer critérios para o acesso aos bens da vida e às situações almejadas. O Estado está, com isso, positivando o seu poder, no sentido de evitar as condutas desagregadoras, estimular as agregadoras, distribuir os bens entre as pessoas - e, por essas formas, criar o clima favorável à paz entre os homens, eliminando as insatisfações. Mas eis que o Estado positiva também o seu poder ao definir situações concretas, decidindo e realizando praticamente os resultados que entende devidos, decidindo e realizando praticamente os resultados que entende devidos em cada caso. Legislação e jurisdição englobam-se, assim, numa unidade teleológica -, ambas engajadas numa tarefa só, de cunho social, que estaria a meio caminho se fosse confiada só à legislação e não teria significado algum se se cogitasse da jurisdição sem existirem normas de direito substancial. E essa missão pacificadora não tem os resultados comprometidos pelo fato de ordinariamente trazerem situação desvantajosa a pelo menos uma pessoa. O importante não é o consenso em torno das decisões estatais, mas a imunização delas contra os ataques dos contrariados, e indispensável, para cumprimento da função pacificadora exercida pelo Estado legislando ou sub specie jurisdictionis, é a eliminação do conflito como tal, por meios que sejam reconhecidamente idôneos. O que importa, afinal, é 'tornar inevitáveis e prováveis decepções em decepções difusas: apesar de descontentes, as partes aceitam a decisão'. Elas sabem que, exauridos os escalões de julgamento, esperança alguma de solução melhor seria humanamente realizável; além disso, ainda que inconscientemente, sabem também que necessitam da proteção do Estado e não convém à tranqüilidade de ninguém a destruição dos mecanismos estatais de proteção mediante a sistemática desobediência”. (cf. Instrumentalidade do processo, p. 160/161).

${ }^{9}$ id., ibidem, p. 161.

${ }^{10}$ cf. Introdução ao estudo do direito, p. 321-329. 
jurídica do exercício da jurisdição ${ }^{11}$ ou o conjunto de normas e instituições destinadas à atuação do poder jurisdicional.

O sistema processual é a face propriamente jurídica da jurisdição e seu escopo jurídico é atuar a vontade concreta da lei, como instrumento de atuação do direito material. $^{12}$

$\mathrm{Na}$ verdade, tratar dos escopos jurídico e social da jurisdição é evidenciar enfoques distintos sobre o mesmo fenômeno, um estritamente jurídico e operacional da jurisdição (técnica processual), mais familiar aos operadores do direito; e outro mais abrangente para justamente explicitar aos operadores do direito o fato da jurisdição não se esgotar em si mesma, mas ser dotadas de finalidades maiores em prol da sociedade, as quais não se restringem ao adequado exercício da técnica processual para atuação do direito material.

O juiz deve assim na aplicação do direito ter consciência e buscar exercer a missão pacificadora da atuação jurisdicional, o que não significa dizer que o juiz no exercício de seu poder jurisdicional pode contrariar o direito material para realizar a almejada pacificação social com justiça. Tal escopo deve ser buscado pelo juiz dentro da lei. Não cabe ao Juiz deslindar dos limites impostos pela constituição e a lei para submeter os jurisdicionados a uma justiça subjetiva e particular, o que não afasta seu poder de fazer as melhores escolhas dentre as possíveis soluções emergentes do ordenamento jurídico para cada caso concreto. $^{13}$

\footnotetext{
${ }^{11}$ cf. Araújo Cintra, Grinover e Dinamarco (Teoria Geral do Processo, p. 24).

12 Neste ponto, compartilhamos da visão de Cândido Rangel Dinamarco para rejeitar a teoria unitária do ordenamento jurídico, defensora da "integração do sistema processual no lavor de criação das situações jurídicas de direito material", e concluir "que o escopo jurídico da jurisdição não é a 'composição' das lides, ou seja, o estabelecimento da regra que disciplina e dá solução a cada uma delas em concreto; a regra do caso concreto já existia antes, perfeita e acabada, interessando agora dar-lhe efetividade, ou seja, promover a sua atuação". (cf. Instrumentalidade do processo, p. 209).

${ }^{13}$ Conforme Cândido Rangel Dinamarco ao tratar da função do Juiz:“ [...] Tanto como o legislador, ele é agente estatal e tem a missão de decidir segundo as escolhas da sociedade. Não é legislador, porém, nem duplicado do legislador teria sentido que fosse ante o sistema político-constitucional da separação dos 'Poderes' do Estado. Só mesmo sob a condição de esvaziar o direito de qualquer conteúdo axiológico e reduzi-lo à norma entendida como mero preceito positivado e depois liberto de ligações com a base social, é que se poderia talvez pensar nessa função como criativa de direito. Os arautos da teoria unitária lançam a barra longe demais, ao equiparar o juiz ao
} 
E o juiz, bem como todos os operadores do direito, devem ter consciência de que a jurisdição não se encerra em seus escopos jurídico e de pacificação social, mas há também outros escopos, de natureza política e social.

Os escopos políticos são de (a) preservação da liberdade, (b) oferta às pessoas de meios de participação nos destinos da nação e do Estado via processo judicial e a (c) preservação do ordenamento jurídico e de sua autoridade. ${ }^{14}$

Um outro escopo social da jurisdição, ao lado da pacificação, de suma importância para a análise que se fará a seguir sobre as repercussões econômicas do sistema jurisdicional, é o de educação, compreendida como a missão de conscientizar os membros da sociedade para direitos e obrigações a partir do exercício continuado e eficiente da jurisdição. ${ }^{15}$

arranjador ou ao intérprete musical, que participam com maior criatividade e dão de si e do seu talento, legitimamente, para o enriquecimento das peças que adaptam ou executam. Quando o juiz extrapola os lindes da lei e dos valores que o clima axiológico da sociedade projeta sobre os fatos em exame, quando ele traz os seus sentimentos e preferências pessoais e os projeta sobre o julgamento que em nome do Estado é chamado a fazer, ele poderá estar criando realmente, mais isso não significa que criar seja sua função institucionalizadora. Tomar o fenômeno (sein) por escopo (sollen) constitui desvio de perspectiva, tanto mais grave quanto as distorções dessa ordem não são sequer apontadas como freqüentes. Além disso, descontados os casos em que o envelhecimento da lei torna obsoleto os seu sentido gramatical e indispensável a descoberta de outros sentidos compatíveis com as exigências axiológicas atuais, o que se tem como ordinário é a correspondência da lei à realidade sócio-política da nação. Os louvores à interpretação evolutiva não podem chegar a algo que se pareça com as idéias da escola do direito livre. O clima de legalidade ditado constitucionalmente no Estado-de-direito repele a institucionalização de sentenças contra-legem, ainda que a 'a lei vigente conduza a resultados viciados ou injustos'. A sujeição do juiz à lei, que não se traduz em culto servil às palavras desta, é impeditiva da 'livre invenção jurídica', tendo-se o governo das leis como inerência dos sistemas jurídicos em que vivemos e como 'imperativo axiológico da segurança jurídica'. Em casos de formar-se um valo entre o texto da lei e os sentimentos da nação, muito profundo e insuperável, perde legitimidade a lei e isso cria clima para a legitimação das sentenças que se afastem do que ela em sua criação veio ditar. Fora disso, carece de suporte a sentença violadora da lei, ante o sistema jurídico como ele é; e sucederá também de carecer de legitimidade, como no caso de exagerada liberalidade no trato da lei penal em tempos de clamor público contra a violência urbana e clima de insegurança" (id., ibidem, p. 198/199).

${ }^{14} \mathrm{cf}$. Cintra, Grinover e Dinamarco (Teoria geral do processo, p. 24).

${ }^{15} \mathrm{cf}$. Cândido Rangel Dinamarco (Instrumentalidade do processo, p. 162). 
Há ainda autores que colocam a segurança jurídica como escopo social da jurisdição. ${ }^{16}$ Tal escopo ou valor social da jurisdição, cotidianamente ventilado nos jornais do país como um dos importantes indutores do desenvolvimento econômico, especialmente por economistas, pode ser entendido como um ambiente de estabilidade e previsibilidade dos direitos e obrigações definidas pelas normas de direito material e sua adequada asseguração pelo sistema jurisdicional. ${ }^{17}$ Trata-se de valor que se liga, e muito, com o escopo social de educação, acima mencionado, já que um dos benefícios mais aventados da segurança jurídica é o da indução de comportamentos, conforme a lei, em razão da certeza de que o descumprimento de obrigações será objeto de punições ou sanções adequadas. ${ }^{18}$

A jurisdição é dotada, portanto, de escopos sociais, de escopos políticos e de seu escopo jurídico de atuação da vontade concreta do direito material. E a explicitação de tais escopos pelos estudiosos do Direito Processual, hoje, não tem o objetivo meramente informativo. Trata-se de uma opção metodológica importante, de colocar a jurisdição e seus escopos no centro do estudo do Direito Processual. Isto porque o processualista vislumbra o processo como instrumento destinado a atingir determinados fins. O resultado do processo passa a ser o centro da preocupação do processualista. Nas palavras de Cândido Rangel Dinamarco: "o direito moderno não se satisfaz com a garantia da ação

\footnotetext{
${ }^{16}$ A menção de que é usual na doutrina a colocação da segurança jurídica como escopo social da jurisdição é feita por Cândido Rangel Dinamarco que, entretanto, prefere qualificá-la como um valor social importante como etapa ao objetivo da pacificação. (Instrumentalidade do processo, p. 162).

${ }^{17}$ Conforme os economistas Armando Castelar Pinheiro e Fábio Giambagi, citados por Jairo Saddi, ao tratar do conceito de segurança jurídica em um espectro maior do que apenas da jurisdição, mas do sistema jurídico como um todo: "No Direito positivo, a segurança jurídica é sustentada por um amplo conjunto de princípios. Destes, vários se voltam para assegurar a continuidade das normas jurídicas e a estabilidade das situações construídas, orientando-se pela regra de que as novas leis são feitas para reger o futuro, e não as situações pretéritas. A certeza das relações jurídicas é outro objetivo importante buscado pelo princípio da segurança jurídica. Isso abarca, de um lado, o princípio da ficção do conhecimento obrigatório da lei, que significa que cabe às pessoas conhecer a norma, identificar o que é obrigatório, proibido e permitido e, com base nesse conhecimento, definir seu comportamento e estruturar suas relações. De outro, que as relações jurídicas nelas baseadas devem ser protegidas pelo poder público. A segurança jurídica também objetiva permitir que os indivíduos programem em bases razoáveis de previsibilidades suas expectativas em relação às implicações futuras de sua atuação jurídica. No que tange às relações jurídicas de cunho econômico, em especial, deve a norma dar ao indivíduo a possibilidade de calcular com alguma previsibilidade as consequiências de suas ações". (cf. Crédito e Judiciário no Brasil, p. 241).

${ }^{18}$ Jairo Saddi afirma: “[...] Se o Direito é por excelência um indutor de comportamentos, é evidente que é preciso, acima de qualquer outra consideração criar um sistema de incentivos em que comportamentos desejados possam ser estimulados e em que existam também controles para aqueles comportamentos indesejáveis. [...] O Direito, como se vê, pode estimular um certo comportamento - certo ou errado, dependendo da opção legislativa e das escolhas socialmente desejáveis - por meio de uma sanção específica que o seu descumprimento embute". (cf. Crédito e Judiciário no Brasil, p. 242).
} 
como tal e por isso é que procura extrair da formal garantia desta algo de substancial e mais profundo. O que importa não é oferecer ingresso em juízo, ou mesmo julgamentos de mérito. Indispensável é que, além de reduzir os resíduos de conflitos não jurisdicionalizáveis, possa o sistema processual oferecer aos litigantes resultados justos e efetivos, capazes de reverter situações injustas desfavoráveis, ou de estabilizar situações justas. Tal é a idéia de efetividade da tutela jurisdicional, coincidente com a da plenitude do acesso à justiça e a do processo civil de resultados."19

Nesse contexto, surge renovado o conceito de tutela jurisdicional, conforme se verificará a seguir. ${ }^{20}$

\subsection{A tutela jurisdicional e suas espécies}

Sabedores das vivas controvérsias na doutrina sobre o alcance e a amplitude do termo tutela jurisdicional, com as quais não é nossa missão lidar, nos basta para os fins pretendidos nesta dissertação utilizá-lo como "proteção do titular de uma situação amparada pela norma substancial [...]". ${ }^{21}$ Trata-se do "resultado da atividade jurisdicional para o qual se aparelham determinados meios. Esse é, aliás, o sentido em que a expressão é mais comumente empregada, prestando-se a traduzir, de ordinário, o resultado do processo em prol do vencedor. É nesse sentido que a expressão tutela jurisdicional viu-se recuperada nos estudos do direito processual e tem merecido especial ênfase na doutrina recente: tanto sob o

\footnotetext{
${ }^{19}$ cf. "Tutela Jurisdicional” in Fundamentos do Processo Civil Moderno, tomo II, p. 798/799.

${ }^{20}$ Segundo Cândido Rangel Dinamarco: “ Tutela jurisdicional é o amparo que, por obra dos juízes, o Estado ministra a quem tem razão num processo. Tutela é ajuda, proteção. É jurisdicional a proteção outorgada mediante o exercício da jurisdição, para que o sujeito beneficiado por ela obtenha, na realidade da vida e das relações com as coisas ou com outras pessoas, uma situação mais favorável do que aquela em que antes se encontrava. Sabido que o escopo magno do processo civil é a pacificação das pessoas e eliminação de conflitos segundo critérios de justiça, consistindo nisso a função estatal a que tradicionalmente se chama jurisdição, segue-se que compete aos órgãos jurisdicionais outorgar essa proteção àquele cuja pretensão seja merecedora dela. O exercício consumado da jurisdição há de ter por resultado a prevalência efetiva de uma pretensão, para que o conflito se elimine e cada um obtenha o que lhe é devido segundo o direito (bens ou situações jurídicas). Sem resultados assim o processo civil careceria de legitimidade." (cf."Tutela Jurisdicional" in Fundamentos do Processo Civil Moderno, tomo II, p. 808)..

${ }^{21}$ cf. Flávio Luiz Yarshell (cf. Tutela Jurisdicional, p. 27).
} 
ângulo da visão do Estado, quanto do ponto de vista do consumidor da Justiça, o processo tem sua efetividade medida pelos resultados substanciais que é apto a proporcionar". 22

A classificação que se faz da tutela jurisdicional focaliza o resultado que o autor obtém com o ajuizamento da ação, a partir de um determinado conflito de direito material não resolvido entre as partes espontaneamente. ${ }^{23}$

Tradicionalmente, tal como a sentença e o processo, a tutela jurisdicional é classificada como de conhecimento, executiva e cautelar. A primeira categoria é ainda sub-dividida em declaratória, constitutiva e condenatória. Esta classificação é alvo de inúmeras críticas, mas será ela extremamente útil aos fins objetivados neste trabalho, ${ }^{24}$ com os devidos temperamentos sempre que sejam pertinentes. Nessa linha, é correta a crítica de que ao pensar-se a tutela jurisdicional como resultado, não é o mais adequado qualificar uma tutela como cognitiva, pois a cognição se refere à atividade desenvolvida pelo Juiz e não ao resultado final do processo. ${ }^{25}$ Pela mesma razão, o mais apropriado seria denominar a tutela executiva de satisfativa. ${ }^{26}$

Feita esta ressalva, passemos a analisar as tutelas declaratória, constitutiva e condenatória, decorrentes do exercício de atividade jurisdicional cognitiva, pela qual o Juiz conhece e julga a causa, declarando qual das partes tem razão em uma sentença de mérito que formula a regra jurídica especial do caso concreto. ${ }^{27}$

\footnotetext{
${ }^{22}$ cf. Flávio Luiz Yarshell (id., ibidem, p. 146).

${ }^{23}$ cf. José Roberto dos Santos Bedaque (Direito e Processo p. 30).

${ }^{24}$ Pontua corretamente José Roberto dos Santos Bedaque: "De qualquer modo, não se pode esquecer que as classificações nada mais são que tentativas de agrupar fenômenos segundo determinado ponto de vista, com o objetivo de melhor compreendê-los. Elas variam, portanto, segundo o ângulo de análise. Por isso, além do cuidado com a homogeneidade de critérios a serem adotados, necessário não elegermos determinada classificação como sendo a única admissível - conclusão incompatível com a visão científica do direito processual". (Efetividade do processo e técnica processual, p. 510).

25 cf. Flávio Luiz Yarshell (Tutela Jurisdicional, p. 151).

${ }^{26}$ Tal como faz José Roberto dos Santos Bedaque ao mencionar as tutelas "cognitiva (declaratória, constitutiva e condenatória), satisfativa ou executiva e cautelar". (Efetividade do processo e técnica Processual, p. 508).

27 cf. Cintra, Grinover e Dinamarco (Teoria Geral do Processo, p. 302).
} 
A tutela declaratória, ou meramente declaratória, já que as tutelas constitutiva e condenatória também têm conteúdo declaratório, destina-se a eliminar uma crise de certeza sobre a existência ou inexistência de um direito ou de uma relação jurídica. ${ }^{28}$

A tutela constitutiva destina-se a modificar uma situação jurídica de maneira a se constituir uma situação jurídica nova. ${ }^{29}$

A tutela condenatória destina-se a eliminar a crise gerada pelo inadimplemento de uma obrigação, mediante a imposição de uma prestação ao devedor e possibilitando a prática de atos de execução tendentes ao cumprimento da prestação imposta. ${ }^{30}$ 31

Nesse sentido, verifica-se que as tutelas meramente declaratória e constitutiva são plenas porque prescindem de atos executivos posteriores à sentença para a satisfação do titular do direito. ${ }^{32}$ Já a tutela condenatória é incompleta, pois para que ocorra a satisfação do titular do direito (o credor), após ter sido proferida a sentença condenatória e

\footnotetext{
${ }^{28}$ cf. Débora Inês Kram Baumohl. (A Nova Execução Civil - A Desestruturação do Processo de Execução, p.12). ${ }^{29}$ cf. Flávio Luiz Yarshell (Tutela Jurisdicional, p. 156).

${ }^{30}$ cf. Flávio Luiz Yarshell (id., ibidem, p. 168-169).

${ }^{31}$ Neste ponto, cabe evidenciar a antiga e conhecida crítica doutrinária sobre a classificação acima (chamada ternária) feita pelos defensores da chamada classificação quinária, segundo os quais deveria se acrescer às três espécies de tutela oriundas da atividade jurisdicional de cognição, as tutelas mandamental e executiva "lato sensu". (Ver neste sentido Ovídio A. Baptistas da Silva, Ação de imissão de posse, p. 56-66). Sob este outro critério, vislumbra-se o provimento mandamental "entendido como aquele que contém ordem para o réu (seja ele um ente particular ou estatal), que deve atendê-la sob pena de caracterizar crime de desobediência ou de que lhe seja imposta alguma medida coercitiva, tal como multa pecuniária, por exemplo. Outro elemento que caracteriza o provimento mandamental é o fato de ele, ao contrário do provimento condenatório clássico, prescindir da instauração de processo subseqüente para que cumpra a ordem nele contida". (cf. Débora Inês Kram Baumohl, $A$ nova execução civil - a desestruturação do processo de execução, p.39). O provimento executivo "lato sensu" teria como sua característica essencial se efetivar imediatamente após proferida a sentença, com "determinações de atos sub-rogatórios (medidas que substituem a vontade do réu)", sem que fosse necessária a instauração de um novo processo de execução (id., ibidem). De todo modo, não é objeto de nossa dissertação adentrar nesta controvérsia doutrinária. De início, nos parece que a classificação ternária é coerente com o conceito de tutela jurisdicional (cf. Flávio Luiz Yarshell, Tutela jurisdicional, p. 177) como resultado da atividade jurisdicional e não como modo de efetivação daquele resultado. Além disso, a classificação ternária nos é operacionalmente útil a demonstrar que a atividade jurisdicional cognitiva, na maioria das vezes, não é suficiente por si só para satisfazer a pretensão do titular do direito reconhecido por sentença.

${ }^{32}$ É bom consignar que as tutelas meramente declaratórias e constitutivas podem implicar na prática de atos simples, usualmente de mero registro da sentença em Cartório, inseridos no rol do que boa parte da Doutrina designa como execução imprópria. Tal como explica Cândido Rangel Dinamarco: "Nesses casos o funcionário age em função da relação de serviço público que o liga ao juiz, com o fito de dar publicidade ao ato levado a registro, sem que se caracterize, em sua atividade, a invasão de uma esfera jurídica, que é característica coessencial à execução". (cf. Execução Civil, p. 99).
} 
sendo esta executável, é necessária a prática de atos jurisdicionais executivos que resultem na tutela executiva (satisfativa). ${ }^{33}$

\title{
2.3. A tutela jurisdicional executiva (satisfativa)
}

\author{
A tutela executiva (satisfativa) destina-se a satisfazer o credor, \\ entregando-lhe o bem da vida indicado no título executivo, ${ }^{34}$ seja este uma sentença \\ condenatória ou um título executivo extrajudicial. ${ }^{35}$
}

Para que tal tutela seja realizada, o Juiz terá à sua disposição os meios e instrumentos legais destinados à sua realização, ${ }^{36}$ configuradores da atividade jurisdicional executiva ou simplesmente execução.

Segundo Araken de Assis: "Dá-se o nome de execução àquelas operações que, em decorrência da natureza do provimento reclamado e obtido pelo vitorioso, se destinam a entregar-lhe o bem da vida. À diferença do que acontece com a certeza e o

\footnotetext{
33 Sobre esta questão José Roberto dos Santos Bedaque observa:"Em termos de efetividade do processo, a proteção conferida pela tutela declaratória é plena, pois prescinde de qualquer providência ulterior para assegurar por completo a satisfação da pretensão reclamada. O mesmo ocorre com a tutela constitutiva que, do ponto de vista prático, opera automaticamente modificação no plano substancial, atendendo integralmente à necessidade de seu titular. Por este mesmo prisma da utilidade da prestação jurisdicional, a tutela executiva aproxima-se bastante da constitutiva, visto que ambas operam concretamente transformações no plano substancial, satisfazendo plenamente aquela pretensão trazida ao mundo exterior. Já, a tutela condenatória é a menos completa, pois não dá solução definitiva à situação da vida. Sua utilidade muitas vezes vai depender de outro provimento jurisdicional o satisfativo- consubstanciado na tutela executiva, pois nem sempre o acatamento do direito nela declarado se faz espontaneamente". (cf. Direito e Processo, p. 37/38).

${ }^{34}$ cf. Flávio Luiz Yarshell (Tutela jurisdicional, p. 172).

${ }^{35}$ Na lição de José Carlos Barbosa Moreira “....a lei confere eficácia executiva a certos títulos, considerando que neles já se acha contida a norma jurídica disciplinadora das relações entre as partes, com suficiente certeza para que o credor se tenha por habilitado a pleitear, desde logo, a realização dos atos materiais tendentes a efetivá-la". (cf. Novo processo civil brasileiro, p. 203).

${ }^{36}$ Lembra Flávio Luiz Yarshell que "entre o momento de invocação da tutela jurisdicional (estudo feito sob o ângulo da ação) e a edição do provimento final, situam-se os meios predispostos à consecução desses objetivos. [...] Impende também, e desde logo, frisar a impossibilidade de desvinculação entre resultados (tutela em favor do vencedor), de um lado, e formas de invocação desse resultado e os meios empregados para a respectiva formação. Não há e nunca haverá resultado adequado sem que se estabeleçam canais e instrumentos adequados para que aquele seja alcançado. É nisso, aliás, que consiste a instrumentalidade do processo." (Tutela jurisdicional, p. 146/147).
} 
estado jurídico novo, que decorrem da própria resolução do juiz, os demais efeitos precisam ser arrancados do mundo dos fatos. Uma bem conhecida metáfora assevera que, através da função predominantemente cognitiva, o juiz transforma fatos na regra jurídica concreta aplicável ao litígio, enquanto a execução percorre o caminho inverso, converte semelhante regra em realidade material. O emprego de outra palavra, em lugar do termo clássico 'execução', como cumprimento, efetivação ou atuação, em muito pouco altera a natureza da respectiva operação. Ela se realiza no mundo real e, portanto, padece das respectivas contingências". 37

Trata-se de uma conceituação abrangente de execução tida como quaisquer operações exercidas pelo Juiz para tornar concreto ou real o provimento reclamado.

Tais operações de execução, continuando na lição de Araken de Assis, se estruturam no sistema processual em diferentes "meios executórios", aquilo que o legislador designa no Livro II, Título II do Código de Processo Civil como as "diversas espécies de execução".38

Assim é que, a depender do objeto perseguido, o Legislador estabelece "meios executórios" ou "meios executivos" aderentes ao fim a que se objetiva realizar com a execução. ${ }^{39}{ }^{40}$ Nesse sentido, como já tivemos oportunidade de salientar, os meios processuais devem ser adequados aos resultados que se pretende alcançar.

\footnotetext{
${ }^{37}$ cf. Cumprimento da sentença, p. 4.

${ }^{38}$ cf. Manual da Execução, p. 128-129.

${ }^{39}$ Mais uma vez nos apoiando em Araken de Assis: "Ora, basta a sinalização do senso comum para indicar que, conforme o objeto colimado - corpus, genus e facere, o último preventiva ou repressivamente, pouco importa -, o meio de atuação variará de maneira dramática. Impedir a poluição do lençol freático por indústria química, despoluir águas do açude e compelir o obrigado inadimplente a entregar determinada quantia são metas díspares, inconfundíveis, que exigem técnicas executivas equivalentemente desiguais. $\mathrm{O}$ inadimplemento de deveres próximos ou remotos, oriundos de direitos relativos ou absolutos, já implica condutas dessemelhadas. E à efetivação coativa das pretensões respectivas, mediante execução, corresponderão, simetricamente, mecanismos bastante diferentes". (id., ibidem, p. 129).

${ }^{40}$ Cândido Rangel Dinamarco aduz que: "As medidas executivas em que consiste a sanção apresentam uma variedade de manifestações, correlativas à diversidade das situações em que o Poder Judiciário é chamado a dar atuação ao direito. A lei institui diferentes meios executivos e os põe à disposição dos órgãos jurisdicionais da execução, para que através do seu emprego os escopos finais de pacificação social e atuação do direito possam ser realizados. [...] Os meios executivos variam segundo a natureza do direito substancial que está à base da demanda deduzida em cada processo de execução, ou do seu objeto, ou da condição do devedor (civil, comerciante; solvente, insolvente)". (cf. Execução Civil, p. 312-313).
} 
Em síntese, nosso sistema processual dispõe de duas classes fundamentais de "meios executivos", também chamados de técnicas de execução: (a) a subrogatória, que prescinde da participação do devedor e (b) a coercitiva que visa a influenciar a vontade do executado. ${ }^{41} 42$

A técnica coercitiva é também chamada de execução indireta e visa a impor sanções ao devedor, não diretamente relacionadas ao objeto da obrigação executada, de forma a impeli-lo ao cumprimento do provimento judicial. Trata-se de impor uma pena ao devedor que será aplicada, caso a obrigação não seja por ele adimplida. Cria-se um incentivo ou um estímulo ao cumprimento da obrigação, representado pelo afastamento da penalidade imposta. $^{43}$

Tal técnica é a única cabível para as obrigações de fazer infungíveis e é especialmente adequada para as obrigações de fazer ainda que fungíveis. No nosso sistema processual pode ser utilizada também para o implemento de obrigações de entrega de coisa certa. Em tese, poderia ser utilizada para o implemento de obrigações de pagar, na medida em que a imposição de pena visa a criar no obrigado um estímulo para que ele cumpra a obrigação espontaneamente, sendo indiferente a natureza da obrigação para que tal estímulo se faça eficaz. Contudo, o nosso sistema processual não prevê a utilização da técnica coercitiva para execução fundada em inadimplemento de obrigação de pagar, com a única exceção, e de modo

\footnotetext{
${ }^{41}$ cf. Araken de Assis (Op. cit., p. 130).

${ }^{42}$ Na lição de José Roberto dos Santos Bedaque fazendo referência a Proto Pisani: "Dependendo da natureza da obrigação, serão atos de sub-rogação (penhora, alienação do bem, realização do ativo e pagamento) ou de coerção (multa, ordem e sanções de natureza vária). Nada impede a combinação de ambas as técnicas. Só é preciso atentar para o fato de que algumas obrigações, como as de fazer infungíveis, não comportam sub-rogação. Para elas, só restam os atos de coerção". (cf. "Algumas considerações sobre o cumprimento da sentença condenatória" in Revista do Advogado, 85/69).

${ }^{43}$ Conforme Cândido Rangel Dinamarco: "O sentido latíssimo aqui examinado conduz a tratar como execução, ainda, as medidas de pressão psicológica exercidas sobre o obrigado, para que cumpra. Trata-se das sanções de direito material, multas inclusive, bem como da prisão admissível em certos casos e das astreintes, de que se falará a seguir. Na realidade, tais medidas não dão efetividade aos preceitos jurídicos mas tão somente põem o obrigado em verdadeiros dilemas. Não se integram ao conceito técnico-processual de execução, ou execução forçada. Melhor designá-las como execução indireta." (cf. Execução Civil, p. 98). É bom notar desde já que o Autor citado, seguindo a doutrina de Liebman e outros, rejeita atribuir à técnica coercitiva o conceito de execução, apontando em nota que “....os chamados meios de coerção não têm natureza executiva: agindo sobre a vontade do obrigado, eles têm o objetivo de conduzi-lo ao cumprimento voluntário do preceito, o que em si é inconciliável com o conceito de execução". (id. ibidem, p. 98-99, nota 5).
} 
restrito, nos casos de cumprimento de sentença (CPC, art. 475-J, capu), ao estabelecer multa de $10 \%$ pelo não pagamento no prazo de 15 dias.

A técnica sub-rogatória pode ser estritamente definida como medida substitutiva da vontade do executado pelo Estado-Juiz, o que, contudo, não é suficiente para a compreensão da extensão da atuação do Estado-Juiz na aplicação de tal técnica. O conceito de execução forçada, utilizado usualmente como equivalente à execução por sub-rogação, cumpre melhor este desígnio, sendo definida por Cândido Rangel Dinamarco como o "conjunto de atos estatais através de que, com ou sem o concurso da vontade do devedor (e até contra ela), invade-se seu patrimônio para, à custa dele, realizar-se o resultado prático desejado concretamente pelo direito objetivo material." ${ }^{44}$

Trata-se de técnica pela qual o Estado-Juiz, independentemente da vontade do devedor, por meio de um conjunto de atos de força visa a realizar o mesmo resultado que decorreria do adimplemento normal ou voluntário da obrigação pelo devedor. ${ }^{45}$

No sistema processual brasileiro a técnica sub-rogatória ou de execução forçada ocorre pelas técnicas de (a) expropriação (CPC, art. 647), (b) desapossamento (CPC, art. 625) e (c) transformação (CPC, art. 634). ${ }^{46}$

A transformação pode ocorrer nos casos em que o devedor se furta a cumprir determinada obrigação de fazer, passível de prestação por terceiro. Nesta situação o credor pode requerer ao Juiz que o fato seja prestado por terceiro à custa do devedor. Cabe, contudo, ao credor adiantar a quantia necessária à realização da prestação pelo terceiro.

Trata-se de maneira pela qual o credor, por intermédio de terceiro, objetiva implementar o cumprimento da prestação, constante de título executivo, e busca

\footnotetext{
44 cf. Cândido Rangel Dinamarco (Execução Civil, p. 112).

${ }^{45}$ Segundo Cândido Rangel Dinamarco há muito tempo “...o direito dos países civilizados institui e cultiva um sistema de medidas destinadas a realizar o mesmo resultado que por ato de sua própria vontade o próprio obrigado deixou de realizar. Trata-se da execução forçada, disposta de modo abstrato na lei e destinada a operar sempre que ocorra uma situação de resistência a fazer alguma prestação pretendida por outrem”. (id, ibidem, p. 102-103).

${ }^{46}$ cf. Araken de Assis (Manual da execução, p. 131).
} 
reaver do devedor a quantia por ele adiantada. No limite, trata-se de procedimento pelo qual o credor obtém a prestação constante do título, ainda que às suas próprias expensas, e há uma conversão da obrigação de fazer do devedor em uma obrigação de pagar, passível de execução pela via expropriatória. ${ }^{47}$

Verifica-se, portanto, que esta técnica atua independentemente da vontade do devedor, mas não há necessariamente a invasão do patrimônio do devedor, ${ }^{48}$ o que pode se dar em momento posterior na execução das quantias incorridas pelo credor na implementação da obrigação de fazer por terceiro.

Nos casos em que se busca a implementação de obrigação de entregar coisa certa, ou de fazer valer direitos reais, a técnica posta à disposição do titular do direito é do desapossamento, regulada pelo art.461-A e 621 do Código de Processo Civil, bem como nas disposições que regulam os procedimentos específicos para proteção de direitos reais. ${ }^{49}$

Por meio desta técnica o Estado-Juiz, diante da individualização de coisa ilegitimamente detida por alguém, tomará a coisa e entregará ao seu legítimo titular, via busca e apreensão, no caso de móveis, e imissão na posse, no caso de imóveis.

Trata-se de técnica inequivocamente substitutiva da vontade do executado (ou sub-rogatória), mas há divergências na Doutrina sobre se, nos casos em que se objetiva a implementação de direitos reais, há de fato invasão do patrimônio do ofensor do direito real pois, segundo alguns, este não teria o bem legitimamente em seu patrimônio e, por

\footnotetext{
${ }^{47}$ Tal como observa Araken de Assis: “O aspecto 'mais saliente' da transformação radica, indubitavelmente, na possibilidade de surgir pretensão a executar a quantia necessária ao custeamento do empreendimento a cargo do terceiro. Tal execução seguirá o modelo expropriativo comum e, diferentemente, do disposto no art. 935-2 do CPC português, há o direito de o executado nomear bens. O valor da dívida se apura em liquidação prévia, abrangendo toda a dívida". (cf. Manual da execução, p. 532-533).

${ }^{48}$ A não ser nos casos em que o objeto da prestação tenha que ocorrer em bem de propriedade do executado. A realização de uma obra, por exemplo, para garantir a segurança do imóvel vizinho. Ou tal como exemplifica Araken de Assis: “....a extirpação de certo defeito construtivo do edifício, localizado na unidade autônoma de um condômino recalcitrante e incivil que impede o uso regular dos equipamentos sanitários do vizinho, terminará por refluir ao figurino do art. 634”. (Manual da execução, p. 137).

${ }^{49}$ cf. Araken de Assis (Manual da Execução, p. 136).
} 
esta razão, tal bem já deveria ser considerado como integrante do patrimônio do titular do direito real. $^{50}$

Nos casos de inadimplemento de obrigações de pagar o sistema processual prevê a utilização da técnica de expropriação, a mais conhecida dos operadores do direito, pois, como é próprio de uma economia de mercado, é na seara do recebimento de dinheiro e liquidação de crédito que gira a maior parte das ações judiciais que tramitam em nossos Tribunais. ${ }^{51}$

A expropriação consiste em apreender ou assegurar bens do devedor, com valor equivalente à obrigação de pagar inadimplida, e expropriá-lo em favor do credor.

A expropriação pode se dar de diferentes formas: pelo desconto em folha de pagamento no caso de execução de prestação alimentícia (CPC, art. 734), e nas outras espécies de obrigações de pagar, pelo usufruto de bens do devedor (CPC, art. 716), pela adjudicação pelo credor de bens do devedor (CPC, art. 685-A) e pela alienação de bens do devedor, na modalidade particular (CPC, art. 685-C) ou pública (CPC, art. 686). ${ }^{52}$

\footnotetext{
${ }^{50}$ Tal divergência gira em torno de outra mais profunda, relativa à classificação das sentenças. Veja neste sentido a posição de Enrico Tullio Liebman que não vê diferença entre a execução para entregar coisa certa com fundamento em direito real ou com fundamento em direito pessoal, tratando-se em ambos os casos de execução com invasão do patrimônio do devedor (cf. Processo de execução, p. 225-226). Outra posição tem Araken de Assis, fazendo referência a Ovídio A. Baptista da Silva, pela qual nas ações executivas com fundamento em direitos reais a execução se dá sobre bem do patrimônio do vencedor da ação (titular do direito real) ilegitimamente detido pelo vencido (ofensor do direito do real). (cf. Manual da execução, p. 504).

51 Nesse sentido, ainda que haja um incentivo cada vez maior em nosso ordenamento jurídico para que os jurisdicionados busquem satisfazer suas pretensões específicas ligadas ao fazer e ao entregar coisa certa, continuam válidas as seguintes observações de Enrico Tullio Liebman ao tratar das execuções por quantia certa aduzindo que ocorrem com mais frequiência do que as outras espécies “...porque na vida de nossos dias é mais freqüente a existência de obrigações de dar quantia certa de dinheiro e também porque muitas vezes as obrigações de conteúdo diferente, não podendo receber execução específica, convertem-se em obrigações derivadas do equivalente pecuniário. A posição especial desta espécie de execução é consequiência da função econômica da moeda, que é de servir como medida comum do valor das coisas e como instrumento universal do pagamento das obrigações. Todos os bens econômicos podem ser avaliados em termos monetários e todos podem também ser convertidos (liquidados) em dinheiro. Por isso, qualquer obrigação pode, em caso de necessidade, ser substituída pelo equivalente pecuniário; e de qualquer patrimônio se pode extrair dinheiro, enquanto houver bens. Deste modo qualquer espécie de crédito pode, em ultima ratio, ser satisfeita por meio de dinheiro." (cf. Processo de execução, p. 29/30).

52 cf. Araken de Assis (Manual da execução, p. 131).
} 


\subsection{A Execução Forçada}

A técnica de expropriação constitui-se na técnica da execução forçada por excelência, na medida em que se faz presente de maneira indubitável a invasão do Estado-Juiz sobre o patrimônio do devedor, independentemente de sua vontade, de maneira a dar aos bens componentes daquele uma destinação econômica favorável ao credor (seja por desconto em folha, usufruto, adjudicação ou alienação).

Por isso, neste trabalho, passaremos a designar a técnica da expropriação como execução forçada, termo que por opção metodológica e para evitar equívocos de entendimento não se referirá às técnicas da transformação e do desapossamento.

Cabe então, neste ponto, enfatizar que a execução forçada é a técnica destinada a concretizar as sentenças e os títulos executivos extrajudiciais de forma a satisfazer o credor de obrigação de pagar quantia. Considerando ainda as recentes reformas de nosso Código de Processo Civil, a execução forçada no caso de sentenças terá lugar no mesmo processo em que proferidas (CPC, art. 475-J) e no caso de títulos executivos extrajudiciais em processo autônomo de execução (CPC, art. 646).

Nos casos de sentença penal condenatória, sentença arbitral e sentença estrangeira homologada pelo Superior Tribunal de Justiça a execução forçada terá lugar em processo autônomo, em razão da necessidade de citação do devedor, mas o rito do processo será o mesmo que o aplicado para as demais espécies de sentenças (CPC, art. 475-J).

E embora haja algumas diferenças de rito na execução de sentenças (também chamada cumprimento de sentenças) e na execução de títulos executivos extrajudiciais, em ambas, caso o devedor não satisfaça espontaneamente a obrigação de pagar, a técnica destinada à satisfação do credor será a mesma, qual seja, a expropriação ou a execução forçada. 
Por isso, ao nos referirmos à execução forçada neste trabalho estamos nos referindo tanto à execução de sentenças como à execução de títulos executivos extrajudiciais.

A penhora, nosso tema central, nada mais é do que um dos atos processuais que integram os "meios executivos" que compõem o sistema da execução forçada.

Assim, a penhora será por nós analisada no contexto do sistema da execução forçada, considerando o seu modo de ser e principalmente as finalidades ou os escopos objetivados por este sistema.

\subsection{Os escopos da Execução Forçada}

A execução forçada destina-se a satisfazer o credor de obrigação de pagamento de quantia em dinheiro, mediante a expropriação de bens do patrimônio do devedor.

Como já se teve oportunidade de mencionar, o escopo da execução forçada é a satisfação do credor, mediante a entrega de dinheiro ou de bem, resultante da expropriação do patrimônio do devedor, em valor equivalente ao da obrigação inadimplida.

Trata-se do escopo jurídico da execução forçada que só com a satisfação integral do credor terá efetivado a atuação da vontade concreta do direito material. E é assim tanto na execução forçada decorrente de sentença condenatória como naquela decorrente de título executivo extrajudicial. Em verdade, como também já tivemos oportunidade de mencionar, a tutela condenatória por si não é plena, havendo necessidade da 
efetiva satisfação do credor via execução para que o direito material possa ser considerado atuado e o processo atingido sua finalidade. ${ }^{53}$

A resolução do conflito, caracterizado pelo inadimplemento de uma obrigação de pagar, só ocorrerá no momento em que o estado de insatisfação do credor estiver concretamente eliminado com o recebimento do dinheiro ou bem em valor equivalente (no caso de adjudicação). Com isso, o escopo social da execução forçada, de pacificação social, será atingido.

De outro lado, a execução forçada, seja por título judicial ou extrajudicial, não terá tido qualquer utilidade ao credor se ele não conseguir obter o bem da vida por ele perseguido. E tal situação não só frustra os interesses do particular, mas frustra também os desígnios da jurisdição ao não conseguir promover a atuação do direito na sociedade, falhando em sua tarefa de tornar a ordem prescrita nas normas jurídicas uma realidade concreta, ${ }^{54}$ o que gera um permanente estado de insatisfação social com repercussões negativas para a sociedade.

Tais repercussões negativas são sensíveis e verificáveis na economia. O bom funcionamento do sistema jurisdicional tende a gerar efeitos positivos na economia e o mau funcionamento efeitos negativos. Isto ocorre porque o funcionamento do sistema jurisdicional afeta o comportamento das pessoas em suas transações econômicas (agentes econômicos). Ao tratar do escopo social de educação, embora sem ter mencionado especificamente a questão econômica, Cândido Rangel Dinamarco bem vislumbrou esta questão ao afirmar que um eficiente exercício da jurisdição educa as pessoas sobre o exercício de seus direitos e obrigações, ou seja, as incentiva a agir conforme a Lei, na medida em que se sabe que seus direitos serão preservados e que o descumprimento à Lei resultará concretamente nas sanções pertinentes. Ao contrário, um ineficiente exercício da jurisdição

\footnotetext{
${ }^{53}$ Conforme exposto por Flávio Luiz Yarshell: “Quando se pensa na tutela jurisdicional como resultado em prol do vencedor, o provimento de natureza condenatória é, de fato, insuficiente para proporcionar ao credor (como tal reconhecido em provimento jurisdicional) o bem da vida por ele pretendido. De fato, excetuada a hipótese de cumprimento voluntário do comando judicial, a tutela - para que seja assim adequadamente qualificada positiva-se por meio do binômio condenação/execução. Daí falar-se em tutela condenatória/executiva". (cf. Tutela jurisdicional, p. 172).

${ }^{54}$ cf. José Ignácio Botelho de Mesquita (Ação civil, p. 85).
} 
gera incentivos para infrações à Lei e fundado receio sobre a capacidade do Estado preservar direitos.

Sob o aspecto econômico, tais incentivos ou desincentivos ao cumprimento da Lei decorrentes do funcionamento da jurisdição em uma dada sociedade irá gerar reações das pessoas em suas transações econômicas, o que resultará em benefícios ou malefícios ao desenvolvimento econômico daquela sociedade.

Tal relação entre jurisdição e economia não pode ser ignorada ao se analisar o sistema de execução forçada, na medida em que esta visa a solucionar conflitos com direto impacto econômico, quais sejam, os inadimplementos de obrigações de pagar. Há sérios estudos econômicos, oriundos inclusive do Banco Central do Brasil, apontando que a taxa de juros bancárias, por exemplo, é afetada pelos entraves de nosso sistema processual para a cobrança de devedores inadimplentes. Assim, nos parece que instrumentos processuais efetivos podem trazer benefícios econômicos e sociais para a sociedade como, por exemplo, uma taxa de juros mais baixa para empresas e cidadãos bons pagadores que deixariam de ser penalizados por um ambiente jurídico favorável ao descumprimento de obrigações contratuais em decorrência da ineficiência do sistema judiciário de fazer valer os direitos de quem tem razão.

É o que procuraremos demonstrar a seguir.

\subsection{Execução Forçada e Economia}

\subsubsection{Delimitação da análise}

Primeiramente, cabe dizer que a nossa análise sobre a relação entre execução forçada e economia cinge-se àquela gama de litígios relacionados a obrigações de pagar por contratos inadimplidos. Nesse sentido, nossa análise não abrange a execução 
forçada atinente a obrigações de pagar decorrentes de atos ilícitos extracontratuais, pois nestes casos a análise econômica tem pressupostos distintos. ${ }^{55}$

Ao celebrar um contrato as pessoas, em princípio, pretendem cumpri-lo. Assim é nos contratos de mútuo, bancários ou não, na concessão de linha de crédito por fornecedor para seu cliente adquirir mercadorias, na atribuição de um cartão de crédito pela Administradora a seu cliente etc..

Caso ocorra o inadimplemento contratual, independentemente de ter o contrato sido formalizado por escrito ou verbalmente, cabe à jurisdição estatal atuar a vontade concreta do direito material, de forma que as partes sejam contempladas com suas respectivas prestações na mesma medida que ocorreria se o contrato tivesse sido cumprido normalmente.

A execução forçada é a técnica utilizada pelo credor para receber quantia não paga, por inadimplemento de obrigações de pagar constantes de sentenças condenatórias ou documentos reputados pela Lei como títulos executivos extrajudiciais, tais como o documento particular assinado por duas testemunhas, a nota promissória, o cheque, a duplicata etc. (CPC, art. 585). Como já tivemos oportunidade de mencionar, a execução forçada é a técnica processual que o credor deve utilizar para receber quantia certa tanto na agora chamada fase de cumprimento de sentença do processo em que esta foi proferida (CPC, art. 475-J), como também no processo autônomo de execução de títulos executivos extrajudiciais (CPC, art. 646).

Munido do título executivo (extrajudicial ou judicial) o credor iniciará a execução forçada, técnica expropriatória pela qual o Poder Judiciário irá apreender bens do devedor para, por meio de alienação judicial ou transferência direta, conforme o caso, transferir ao credor dinheiro ou bem do patrimônio do devedor no exato montante de seu crédito em cumprimento ao contrato.

\footnotetext{
55 Para conhecer as linhas da análise econômica do ato ilícito extracontratual ver Cooter e Ulen, Law \& Economics, p. 307/349.
} 
O funcionamento do sistema jurisdicional da execução forçada tem relevantes consequências econômicas, pois se trata de instituição que afeta os custos de transação dos agentes econômicos e, portanto, a performance do agregado da atividade econômica. ${ }^{56}$ Antes, porém, de adentrarmos nesta discussão é preciso tratar de alguns conceitos que utilizaremos em nossa análise, tirados do estudo do Law\&Economics ou da Análise Econômica do Direito.

\subsubsection{Os custos de transação}

Em uma economia de mercado, tal como a brasileira em que a propriedade é privada e o regime é o da livre iniciativa dos agentes econômicos, pessoas e empresas interagem entre si para transacionar direitos de propriedade, ${ }^{57} \mathrm{em}$ busca de ganhos mútuos.

A definição, proteção e manutenção dos direitos de propriedade trazem custos para seus titulares ${ }^{58}$ os quais são incorridos inclusive e principalmente no momento de transacioná-los com terceiros (definição dos direitos transacionados, modo e condições da transação e garantia do exercício pleno e efetivo do novo arranjo dos direitos de propriedade que emergem da transação).

\footnotetext{
${ }^{56}$ Segundo Décio Zylbersztajn e Raquel Sztajn, estudiosos do Law and Economics ou da Análise Econômica do Direito: “ [...] As instituições, por seus efeitos sobre os custos de troca e produção, afetam decisivamente a performance econômica e, juntamente, com a tecnologia empregada, elas, as instituições, determinam os custos de transação e transformação que formam os custos totais da atividade econômica em determinado ambiente". (cf. "Análise Econômica do Direito e das Organizações" in Direito \& Economia ,p. 3).

${ }^{57}$ Conforme Sztajn, Zylbersztajn e Mueller: "A definição dominante de direitos de propriedade, tanto em Economia como em Direito, é de propriedade como sendo um conjunto de direitos (bundle of rights) sobre um recurso, que o dono está livre para exercer e cujo exercício é protegido contra interferência por outras agentes. Nessa definição, propriedade consiste em uma série de relações entre pessoas e só incidentalmente envolve uma "coisa" ou um bem."( cf. "Economia dos direitos de propriedade". In: Direito \& Economia , p. 92)

${ }^{58} \mathrm{De}$ acordo com Sztajn, Zylbersztajn e Mueller: "Note que os direitos que constam do conjunto não são absolutos e dependem dos esforços que o proprietário coloca em defender cada direito das tentativas de captura por outros indíviduos e da proteção provida pelo governo. Como nota Barzel, é razoável supor que os custos de proteger cada direito são crescentes no nível de segurança desejado, de modo que nunca compensará tentar obter um direito perfeitamente seguro" (cf. "Economia dos direitos de propriedade". in Direito \& Economia , p. 92).
} 
De maneira didática Cooter e Ulen afirmam que os custos de transação são os custos de troca, os quais são de três espécies, (a) os custos de localizar o parceiro comercial, (b) os custos da barganha por meio de negociação e redação do instrumento contratual e (c) os custos do monitoramento da performance das partes e da aplicação de punições a violações ao acordo (enforcement). ${ }^{59}$

O Teorema de Coase deduzido a partir do clássico artigo "The Problem of Social Cost" do economista Ronald Coase nos ensina que em um ambiente ideal com direitos de propriedade bem definidos e custos de transação igual a zero, sob o enfoque da eficiência econômica, não importa em uma transação a distribuição inicial dos direitos/obrigações entre as partes feita pela Lei, uma vez que as partes vão negociar para utilizar os recursos objeto da transação da maneira mais eficiente possível.

Neste ponto, cabe uma breve explicação sobre o conceito de eficiência para os economistas, ferramenta fundamental para se entender a abordagem dos problemas legais feita pela Análise Econômica do Direito, método de estudo que utilizamos neste trabalho. Para esta definição há dois critérios mais utilizados. Nesse sentido, uma mudança na distribuição de recursos na sociedade é considerada eficiente, segundo o critério de Pareto, quando ao menos uma pessoa ganhe sem que nenhuma outra pessoa na sociedade sofra uma perda. Uma evolução deste critério, considerada hoje mais apropriada, é a chamada eficiência Kaldor-Hicks pela qual, ainda que alguém sofra uma perda, uma solução eficiente na distribuição de recursos ocorre quando os ganhos gerados aos ganhadores são maiores do que as perdas ocasionadas aos perdedores, situação que gera um ganho para a sociedade. ${ }^{60}$

Volta-se agora ao Teorema de Coase, a partir de um exemplo bastante didático de Sztajn, Zylbersztajn e Mueller:

“ [...] Suponha uma fábrica que jogue dejetos em um rio do qual um fazendeiro retira água para irrigar sua plantação. A poluição no rio reduz a renda do fazendeiro em $\$ 500$. O fazendeiro pode evitar

\footnotetext{
${ }^{59}$ cf. Law \& Economics (p. 91/92).

${ }^{60} \mathrm{cf}$. Cooter e Ulen (Law \& Economics, p. 48).
} 
esse custo construindo uma planta de purificação de água que custa \$300. Já a fábrica pode eliminar a poluição colocando um filtro que custa $\$ 100$. Se a fábrica ou o fazendeiro fecharem ou se mudarem, o custo individual será superior a \$1000. A questão é determinar como a lei deve lidar com esse caso. A quem ela deve dar o Direito de Propriedade sobre o uso da água de modo a levar à alocação eficiente de recursos?

O argumento de Coase é que se não houver custos de transação, então basta que os direitos de propriedade sejam bem definidos, que ambos os agentes irão voluntariamente negociar de modo a levar os recursos a seu uso mais eficiente. Em outras palavras, contanto que os direitos de propriedade sejam bem definidos e não haja custos de transação, o uso eficiente dos recursos será automaticamente atingido independente de quem tenha direito à água do rio. Note que o uso eficiente de recursos no exemplo é que a fábrica instale o filtro, que custa $\$ 100$. Qualquer outro resultado levaria a um custo maior do que $\$ 100$, quer seja a cessação de produção pela fábrica ou pela fazenda (\$1000), a instalação da planta de purificação (\$ 300) ou o fazendeiro continuar usando água poluída (\$ 500). Dessa forma, qualquer desses resultados representaria uma alocação ineficiente dos recursos. Quando o fazendeiro tem direito a água limpa, ele estaria disposto a abrir mão daquele direito e deixar a fábrica poluir se esta lhe compensasse em $\$ 300$ ou mais, pois então poderia construir a planta de purificação. Todavia, a fábrica prefere colocar um filtro, que lhe custa $\$ 100$, e continuar produzindo. Nesse caso, não há barganha, mas o resultado final é o eficiente. Já se a fábrica tem o Direito de Propriedade de poluir o rio, o melhor que o fazendeiro pode fazer é lhe oferecer \$ 100 ou mais para instalar o filtro. Em ambos os casos, independente_de quem detinha o Direito de Propriedade, o resultado foi eficiente, ou seja, a instalação do filtro. A distribuição de renda entre os agentes após a barganha é afetada pelo Direito de Propriedade. Aquele que detém o direito sempre sai ganhando. No entanto, a distribuição de renda não é o que está sendo discutido no Teorema de Coase e sim a eficiência econômica." (grifos nossos.) ${ }^{61}$

Verifica-se a partir do exemplo acima que em um ambiente de custos de transação igual a zero, seja na hipótese da Lei responsabilizar a fábrica pelos danos causados à fazenda pela poluição do rio ou, ao contrário, na hipótese da Lei afastar a incidência desta responsabilidade da fábrica, as partes vão negociar de modo a alcançar a

\footnotetext{
${ }^{61}$ cf. "Economia dos direitos de propriedade" in Direito \& Economia , p. 92.
} 
solução mais eficiente do ponto de vista econômico que é instalar o filtro na fábrica, a um custo de \$100, independentemente de qual seja a distribuição inicial dos direitos de propriedade definida pela Lei.

Contudo, o Teorema de Coase também nos ensina que no mundo real os custos de transação são usualmente positivos e nos casos em que os custos são altos a ponto de tornar difícil a negociação entre as partes para se estabelecer um novo arranjo dos direitos de propriedade estabelecidos pela Lei, a definição legal sobre a distribuição inicial dos direitos de propriedade afetará diretamente a eficiência econômica. No exemplo acima, em um ambiente de custos de transação positivos, caso a fábrica estivesse legalmente eximida de responder pela poluição causada ao rio ou de preveni-la adequadamente, é possível que o fazendeiro ao invés de oferecer \$ 100 à fábrica para que ela instalasse um filtro ele decidisse por gastar \$ 300 para instalar em sua propriedade a planta de purificação. Tal poderia ocorrer, por exemplo, pela dificuldade de acesso à informação pelo fazendeiro de que a contratação pela fábrica de um filtro de $\$ 100$ resolveria o problema da poluição no rio; pela dificuldade de acesso aos representantes da fábrica; pela necessidade de contratar peritos em problemas de poluição de rios, enfim, todos fatores que representam custos de transação positivos.

Por isso Ronald Coase ressalta que “...as cortes exercem uma influência direta sobre a atividade econômica. Parece então desejável que as cortes devam entender as conseqüências econômicas de suas decisões, e deveriam, na medida em que isso seja possível sem criar muita incerteza sobre o próprio posicionamento legal, levar em conta essas conseqüências ao tomar suas decisões. "62

Nesse sentido, dado que na realidade os custos de transação são normalmente positivos, a definição e distribuição inicial dos direitos de propriedade pela lei e sua aplicação pela jurisdição afeta diretamente a eficiência econômica na distribuição de recursos de uma dada sociedade.

\footnotetext{
62 cf. The Problem of Social Cost. Trata-se de tradução livre do seguinte excerto: “...the courts directly influence economic activity. It would therefore seem desirable that the courts should understand the economic consequences of their decisions and should, insofar as this is possible without creating too much uncertanty about the legal position itself, take these consequences into account when making their decisions."
} 
O Teorema de Coase recomenda então que os legisladores se esforcem para reduzir os custos de transação, de forma que haja menos obstáculos para que as partes barganhem, pois estas tendem a encontrar soluções mais eficientes na distribuição dos direitos de propriedade do que o sistema legal. ${ }^{63}$

De outro lado, sabido que nem sempre as partes cooperam entre si na barganha de direitos, ainda que os custos de transação sejam baixos, o sistema legal deve procurar minimizar os danos causados à sociedade pela perda do ganho que seria gerado pela negociação entre as partes, fazendo a atuação da lei da forma mais eficiente possível. Este princípio é chamado por Cooter e Ulen de Teorema de Hobbes. ${ }^{64}$

Disto resulta dois princípios: a) o sistema legal deve reduzir custos de transação para incentivar a realização de transações privadas e b) o sistema legal deve procurar alocar os direitos de propriedade, em caso de não cooperação, de maneira eficiente.

\subsubsection{O papel das instituições}

O termo "sistema legal" utilizado no tópico precedente deve ser entendido como denominação genérica para o arcabouço de normas jurídicas (de direito material e de direito processual), órgãos governamentais e órgãos jurisdicionais que regulam a vida em sociedade. O sistema legal pode ser entendido como uma instituição que estabelece e aplica um determinado conjunto de regras na sociedade.

\footnotetext{
${ }^{63}$ Segundo Cooter e Ulen: "By lubricating bargaining, the law enables the private parties to exchange legal rights, thus relieving lawmakers of the difficult task of allocating legal rights efficiently." (Law \& Economics, p. 97) E segundo Oliver Williamson: “...a maior parte das disputas incluindo muitas que poderiam ser levadas às cortes, é resolvida por medidas de precaução, auto-suporte e formas similares. Isso ocorre, pois 'em muitas circunstâncias os envolvidos estão mais capacitados a identificar soluções satisfatórias para as suas disputas do que os profissionais restritos à aplicação de regras gerais baseados no conhecimento limitado da disputa". (cf. "Por que direito, economia e organizações?, in Direito \& Economia, p. 48).

${ }^{64}$ Segundo os Autores: "Besides encouraging bargaining, a legal system tries to minimize disagreements and failures to cooperate, which are costly to society. The importance of minimizing the losses from disagreements was especially appreciated by the $17^{\text {th }}$-century English philosopher Thomas Hobbes. Hobbes thought that people would seldom be rational enough to agree on a division of the cooperative surplus, even when there were no serious impediments to bargaining.Their natural cupidity would lead them to quarrel unless a third, stronger party forced them to agree.[...]" (cf. Law \& Economics, p. 97).
} 
Com instituições que reduzam os custos de transação e garantam o pleno exercício dos direitos de propriedade os países dotados de economia de mercado ganham em eficiência e em desenvolvimento econômico. ${ }^{65}$

Na lição de Douglass North, citado por Mary M. Shirley, "em lugares onde as instituições aumentam a certeza de que serão honrados contratos e protegida a propriedade, os indivíduos estarão mais propensos a especializar, investir em ativos irrecuperáveis, empreender transações complexas, $e$ acumular e partilhar conhecimento", ${ }^{66}$ com ganhos econômicos para a sociedade.

Em seu artigo Mary M. Shirley cita dois grupos de instituições: “(i) os que promovem permuta mediante a redução de custos de transação e encorajamento de confiança, e (ii) os que influenciam o estado e outros protagonistas poderosos a proteger a propriedade privada e pessoas ao invés de expropriá-las e subjugá-las. O primeiro conjunto de instituições inclui os contratos e mecanismos de execução de contratos, normas e regras comerciais, e hábitos e crenças que favoreçam valores compartilhados e a acumulação de capital humano. No segundo conjunto de instituições, estão constituições, regras eleitorais, leis que regem a expressão e educação, e normas que motivam as pessoas a acatar as leis e cooperar em monitorar o governo. "67

Para o objeto deste trabalho nos interessa analisar os contratos e o funcionamento da jurisdição.

\footnotetext{
${ }^{65} \mathrm{cf}$. Institutions and Development, p. 614 ..

${ }^{66}$ id, ibidem, p. 611. Trata-se de tradução livre do seguinte excerto:'[...] in places where institutions increase the certainty that contracts will be honored and property protected, individuals will be more willing to specialize, invest in sunk assets, undertake complex transactions and accumulate and share knowledge [...]"

${ }^{67}$ op. cit., p. 611. Trata-se de tradução livre do seguinte excerto: "[...](i) those that foster exchange by lowering transaction costs and encouraging trust, and (ii) those that influence the state and other powerful actors to protect private property and persons rather than expropriate and subjugate them. The first set of institutions includes the contracts and contracts enforcement mechanisms, commercial norms and rules, and habits and beliefs favoring shared values and the accumulation of human capital. Among the second set of institutions are constitutions, electoral rules, laws governing speech and education, and norms that motivate people to abide by laws and cooperate in monitoring government [...]".
} 
O contrato é um importante instituto de direito privado que visa a reduzir incertezas e riscos naturalmente existentes em transações com prestações a serem cumpridas no futuro. Trata-se de acordo de vontades dotado daquilo que os norte-americanos denominam enforceability, algo que poderíamos transpor para o português para exequibilidade ou capacidade de ser executado de maneira forçada.

Os elementos básicos de qualquer transação são comprometimento e cooperação das partes. Celebrando um contrato, as partes são estimuladas a cooperar, ainda que o cumprimento das prestações seja diferido para momento futuro, em razão da enforceability.

Como ensinam Coter e Ulen, pelos quais nos pautamos também nos dois parágrafos precedentes, “[...]ao executar a promessa, a corte poderá dar a ambas as partes o que desejam. Dando-lhes o que desejam promove a permuta e encoraja a cooperação através da redução de incerteza e risco. "68

E segundo Zylbersztajn e Sztajn, explicando a contribuição de Oliver Williamson ao Law \& Economics, "os agentes abster-se-ão de quebrar os contratos se os custos de rompimento forem maiores do que os benefícios de fazê-lo, de acordo com a tese sugerida por Benjamin Klein [...]. Cabe destacar que os custos de romper os contratos de modo oportunístico estão associados a mecanismos privados (perda de reputação) ou públicos (penalização pela justiça)". ${ }^{6}$

O papel da jurisdição ou do sistema processual é então o de garantir o cumprimento dos contratos, fazendo valer de fato um de seus elementos principais que é a enforceability, conferindo direitos à parte que os tem e impondo à parte inadimplente os encargos e prestações com os quais se comprometeu, o que nada mais é, em uma linguagem processual, do que a atuação da vontade concreta do direito material.

\footnotetext{
${ }^{68}$ cf. Law and Economics (p. 196). Trata-se de tradução livre do seguinte trecho:’[...] by enforcing the promise, the court can give both parties what they want. Giving them what they want promotes exchange and encourages cooperation by reducing uncertainty and risk.[...]".

${ }^{69}$ cf. “Análise Econômica do Direito e das Organizações” in Direito \& Economia , p. 9.
} 
Uma jurisdição eficiente que garanta o cumprimento dos contratos, conferindo ressarcimento integral à parte prejudicada pelo inadimplemento contratual diminui os custos de transação, na medida em que atua para reduzir e idealmente eliminar os riscos e incertezas do inadimplemento, e de outro lado, aumenta os custos do inadimplemento contratual, desincentivando as partes a atuarem de maneira oportunista, em razão da certeza da punição. $^{70} 71$

$\mathrm{Na}$ lição de Coter e Ulen: "[...] a expectativa de perfeita reparação do dano restaura a promissário a condição que ele ou ela teria desfrutado caso a promessa tivesse sido mantida. [...] A promessa obriga o promitente a cumprir. Quanto maior o custo da responsabilidade, maior o compromisso de cumprimento criado pela promessa. Quando a responsabilidade for estabelecida a nível eficiente, o promitente cumprirá se o cumprimento for mais eficiente que o rompimento, e o promitente romperá se o rompimento for mais eficiente que o cumprimento. Consequentemente, a expectativa de perfeita reparação do dano evoca compromisso eficiente do promitente em cumprir. "72

\footnotetext{
${ }^{70}$ Segundo Jairo Saddi: “A importância de um sistema judicial está na capacidade de proteger contratos e garantir os direitos de propriedade, sobre os quais se pressupõem quaisquer produtos financeiros e de crédito, com base em um sistema de normas coerentes que vincula umbilicalmente a justiça e o desenvolvimento econômico. Douglass North, prêmio Nobel de Economia foi quem melhor entendeu essa ligação. Ele resume: 'De fato, a dificuldade em criar um sistema judicial dotado de relativa imparcialidade, que garanta o cumprimento dos acordos, tem se mostrado um impedimento crítico no caminho do desenvolvimento econômico. No mundo ocidental, a evolução dos tribunais, dos sistemas legais e de um sistema judicial relativamente imparcial desempenha um papel preponderante no desenvolvimento de um complexo sistema de contratos capaz de estender no tempo e no espaço, um requisito essencial para a especialização econômica'." (cf. Crédito $e$ Judiciário no Brasil, p. 235).

${ }_{71}$ Aqui deve-se fazer uma ressalva importante, pois a plena enforceability dos contratos não depende apenas do bom funcionamento da jurisdição estatal considerada isoladamente, mas também dos instrumentos que o Poder Judiciário terá à sua disposição para exercer sua missão, "em particular a capacidade dos tribunais de julgarem com presteza, justiça e previsibilidade depende de as leis terem sentido claro e serem bem escritas e consistentes com outras leis e com as práticas comerciais. Da mesma forma, para que os tribunais funcionem de forma eficiente, os contratos, quer se refiram a partes privadas, quer envolvam o Estado, devem estar corretamente elaborados, ser consistentes com a legislação e conter cláusulas passíveis tanto de verificação como de aplicação. É necessário, portanto, não só a existência de legisladores e juizes competentes, mas também de advogados e contadores bem preparados".(cf. Armando Castelar Pinheiro, "Impacto sobre o crescimento: uma análise conceitual" in Judiciário e economia no Brasil, p. 24).

72 cf. Law and Economics, p. 202. Trata-se de tradução livre do seguinte trecho: “ [...] perfect expectation damages restore the promisee to the position that he or she would have enjoyed if the promise had been kept. [...] The promise commits the promisor to perform. The higher the cost of liability, the stronger the commitment to perform created by the promise. When liability is set at the efficient level, the promisor will perform if performance is more efficient than breaching, and the promisor will breach if breaching is more efficient than
} 


\subsubsection{Execução Forçada: uma análise crítica}

A execução forçada é a técnica processual destinada a garantir a enforceability dos contratos que contenham obrigações de pagar, seja a partir de uma sentença que reconheceu o inadimplemento contratual de uma das partes que condenou ao pagamento de quantia, seja a partir de um título executivo extrajudicial que já abre a possibilidade da atuação satisfativa, independentemente de prévia cognição jurisdicional. Assim sendo, a execução forçada, em conjunto com os órgãos jurisdicionais que a aplicam, pode ser entendida como a instituição jurisdicional (ou o sistema) que se destina a garantir que as partes contratantes obtenham as prestações contratadas, ainda que uma das partes não se disponha a cumprir espontaneamente sua obrigação.

O sistema de execução forçada existe para que o Estado-Juiz afete a esfera patrimonial do devedor, sujeite seus bens ao cumprimento da obrigação consignada no título executivo, realize a expropriação judicial e satisfaça integralmente o direito do credor.

Contudo, conforme Cândido Rangel Dinamarco já há algum tempo alertava: “...todos sentem as mazelas da execução forçada, tal qual configurada no direito moderno. São demasiadas as oportunidades de defesas e retardamentos que a lei oferece ao executado, beneficiando inúmeras vezes o mau pagador, sendo indulgente com chicanas em detrimento da plena satisfação do credor e do correto exercício da jurisdição. Sem dizer do mau funcionamento da Justiça, cartórios desaparelhados, juízes pouco participativos. O que se dirá a partir dos tópicos seguintes e nos capítulos subsequentes, com fidelidade à regra da execução humanizada, seja portanto entendido em harmonia com essa preocupação por agilizar a execução forçada. É preciso aparelhar os ofícios judiciários e, de lege ferenda, buscar caminhos para pôr fim a essa situação cômoda que ampara desmesuradamente aqueles que se valem da Justiça para retardar ou evitar desembolsos."73

performing. Consequently, perfect expectation damages elict efficient commitment from the promisor to perform".

73 cf. Execução Civil, p.96. 
Não se deve deixar de elogiar as notáveis reformas de nosso Código de Processo Civil ( Leis n. 11.232/2005 e 11.382/2006), as quais visam a dar mais celeridade e eficiência ao sistema de execução forçada, tanto no caso de sentenças, como também no caso dos títulos extrajudiciais, mas ainda é cedo para dizer que tais mudanças legislativas dotaram o sistema processual brasileiro de uma execução forçada plenamente adaptada à realidade econômica e social atual e reconhecidamente eficiente em sua finalidade de satisfazer plenamente credores de obrigações de pagar inadimplidas.

Obviamente, as razões da ineficiência do sistema não são apenas legislativas, e neste aspecto parece que demos um importante passo com a realização de tais reformas, mas são também de ordem histórica, cultural, econômica, administrativa etc..

Historicamente, não se pode negar que nosso Legislador muitas vezes desvirtuou a consagração do direito de defesa e do direito de recorrer a instâncias superiores em oportunidades múltiplas e intermináveis de postergar e protelar o cumprimento de decisões judiciais, com base em discussões judiciais infundadas, em um contexto de um Poder Judiciário assoberbado de trabalho, dotado de práticas administrativas antiquadas, com parcos recursos técnicos e financeiros para atender às inúmeras demandas que chegam a seus escaninhos.

O mau uso da técnica processual também contribuiu para um ambiente pouco orientado para as finalidades da jurisdição, o que resultava em uma atuação jurisdicional mais preocupada com as formalidades e tecnicismos processuais do que com a resolução do conflito e a pacificação social.

Não há dúvida que esta mentalidade vem se modificando a partir da difusão da nova fase de estudos do Direito Processual, fundada na maior ênfase à instrumentalidade do processo que procura realçar os escopos sociais e políticos da jurisdição, tal como pudemos brevemente expor nos itens precedentes. Os processualistas brasileiros hoje 
se preocupam mais com a finalidade do processo $^{74}$ de solucionar os litígios de maneira satisfatória para as partes e para a sociedade. ${ }^{75}$

O fato é que essas mudanças no enfoque e no ensino da Teoria Processual, bem como as mudanças legislativas, têm um prazo de maturação longo para de fato produzirem efeitos em uma estrutura judiciária complexa, com infra-estrutura deficiente e dotada de costumes e práticas arraigados há séculos.

Nessa linha, deve-se ressaltar a produção cada vez mais intensa de estudos que procuram analisar com instrumentos de análise empíricos e estatísticos o modus operandi do Poder Judiciário brasileiro para conhecê-lo melhor, desmistificar determinados conceitos, enfim, que começam a estudar o Poder Judiciário com base em premissas científicas aferíveis e mensuráveis.

Por exemplo, muito se fala de uma suposta postura ideológica dos Juízes brasileiros em determinadas matérias, tendendo a favorecer uma das partes do processo, ainda que contrariando disposições legais e contratuais.

Armando Castelar Pinheiro em estudo denominado "Magistrados, Judiciário e Economia no Brasil", ${ }^{76}$ a partir de pesquisa de opinião feita com 741 Magistrados

\footnotetext{
${ }^{74}$ Ensina José Roberto dos Santos Bedaque: “...Trata-se, sem dúvida, de nova visão do fenômeno processual, instrumento cuja utilidade é medida em função dos benefícios que possa trazer para o titular de um interesse protegido pelo ordenamento jurídico material. A conscientização de que o processo vale não tanto pelo que é, mas fundamentalmente pelos resultados que produz, tem levado estudiosos a reexaminar os institutos processuais, a fim de sintonizá-los com a nova perspectiva metodológica da ciência". E continua: "Parece imprescindível, pois, um retorno ao interior do sistema processual, com o objetivo de rever conceitos e princípios, adequando-os à nova visão desse ramo da ciência jurídica. É preciso 'revisitar' os institutos processuais, todos concebidos segundo a visão autonomista ou conceitual da ciência processual, a fim de conferir a eles nova feição, a partir das necessidades identificadas na fase instrumentalista". E por fim: "O tratamento dos institutos fundamentais de nossa ciência deve perder a conotação excessivamente processualista. A abordagem precisa levar em consideração critérios de racionalidade material, não apenas formal” (cf. Direito e Processo p. 16).

${ }^{75}$ Segundo Kazuo Watanabe: "Não se trata de negar os resultados alcançados pela ciência processual até esta data. $\mathrm{O}$ que se pretende é fazer dessas conquistas doutrinárias e de seus melhores resultados um sólido patamar para, com uma visão crítica e mais ampla da utilidade do processo, proceder ao melhor estudo dos institutos processuais - prestigiando ou adaptando ou reformulando os institutos tradicionais, ou concebendo institutos novos -, sempre com a preocupação de fazer com que o processo tenha plena e total aderência à realidade sóciojurídica a que se destina, cumprindo sua primordial vocação que é a de servir de instrumento à efetiva realização dos direitos. É a tendência ao instrumentalismo que se denominaria substancial em contraposição ao instrumentalismo meramente nominal ou formal." (cf. Da cognição no processo civil, p. 20/21).
} 
em todo o Brasil, sugere que predomina a visão entre os magistrados de privilegiar a justiça social em detrimento do estrito cumprimento da lei e do cumprimento dos contratos, algo que poderia indicar uma tendência de atuar nos processos de maneira redistributiva, transferindo renda de quem tem para quem não tem. Trataria-se de uma tendência dos Juízes a ignorar a lei em prol de um conceito de justiça particular, situação não desejável do ponto de vista dos escopos da jurisdição, que deve necessariamente atuar a vontade concreta do direito material, gerando efeitos danosos sobre o valor social da segurança jurídica com repercussões negativas sobre os custos das transações econômicas, encarecendo-as e dificultando-as por força de uma maior imprevisibilidade sobre a efetiva proteção jurídica daquela transação (enforceability).

Ivan Ribeiro a partir da análise de decisões judiciais proferidas por Juízes de 16 Estados brasileiros não verificou o favorecimento de partes mais fracas pelos Juízes, em detrimento do cumprimento de cláusulas contratuais, mas verificou a tendência de Juízes favorecerem partes locais com influência política e econômica. ${ }^{77}$

Estudos deste tipo são de grande valia e precisam ser fomentados, mas ainda, no nosso entender, não podem ser considerados conclusivos sobre a existência ou não de viés ideológico na atuação dos Juízes brasileiros. No caso de pesquisa de opinião, há incerteza sobre se a opinião externada pelo Juiz se reproduza em sua atuação judicial. No caso da análise de decisões judiciais pela falta de uma amostragem mais representativa das decisões judiciais proferidas em Tribunais de todo o Brasil. Além do que, não se deve desconsiderar na análise muitas das leis brasileiras que contém princípios ou conceitos dúbios sobre a forma de aplicação do direito; ou normas que tendem a gerar proteção, às vezes, desproporcional a uma das partes do contrato.

De qualquer forma não se pode negar que alguns setores empresariais, principalmente o bancário, percebem viés ideológico dos Juízes no julgamento de determinadas matérias, ${ }^{78}$ por exemplo na limitação de taxa de juros de mútuo bancário, em

\footnotetext{
${ }^{76}$ in Direito \& Economia.

77 cf. Robin Hood vs.King John Redistribution: How do local Judges Decides Cases in Brazil.

78 cf. Márcio Aith. "O impacto do Judiciário nas atividades das instituições financeiras" in Judiciário e Economia no Brasil, passim.
} 
detrimento da plena execução dos contratos, percepção por si só suficiente para comprometer a segurança e previsibilidade dos agentes econômicos em suas transações.

No mais, Armando Castelar Pinheiro mostra a partir de modelo econométrico que "a utilidade advinda da utilização de um mecanismo específico de resolução de conflitos, como o judiciário, depende dos custos envolvidos, da rapidez com que uma decisão é alcançada, da imparcialidade do árbitro, da taxa de juros (ou, mais precisamente, da taxa de desconto intertemporal), e da previsibilidade das decisões e do tempo até que elas sejam alcançadas. O modelo mostra que um sistema que funciona bem deve ostentar as seguintes propriedades: baixo custo de acesso e decisões justas, rápidas e previsíveis em termos de conteúdo e de prazo."

O sistema de execução forçada brasileiro ainda é instituição ou mecanismo de solução de conflitos muito lenta e pouco previsível. Não há segurança de que o credor terá seu direito de crédito satisfeito em determinado tempo ou mesmo se o direito de crédito virá a ser de fato satisfeito.

Esta situação acarreta um aumento dos custos de transação, em razão da incerteza de que os Tribunais garantirão ao credor o perfect expectation damages (expectativa de perfeita reparação dos danos), e gera um incentivo para o devedor agir de maneira oportunística se apropriando dos direitos de propriedade do credor. O aumento dos custos de transação tende a reduzir o número de transações, pela redução de oferta de determinado produto ou serviço e pelo aumento do preço deste mesmo produto ou serviço, prejudicando os bons pagadores não tendentes a atuar de maneira oportunística. Tudo isto reflete em uma atividade econômica menor, com prejuízo para toda a sociedade. O caso do spread bancário no Brasil ajudará a ilustrar esta situação.

\section{]}

\footnotetext{
${ }^{79}$ cf. Impacto sobre o Crescimento: Uma Análise Conceitual, p. 27/28.
} 


\subsubsection{Um exemplo: o spread bancário}

A composição do spread pelos bancos brasileiros pode ajudar a entender como a deficiência no funcionamento do sistema de execução forçada pode ter impacto negativo na economia.

Há estudos de técnicos do Banco Central do Brasil e também de outros economistas que relacionam parte do elevado spread bancário praticado pelos bancos brasileiros à ineficiência de nosso sistema judicial de cobrança de dívidas. Embora estes estudos não se refiram especificamente a nenhum tipo de mecanismo judicial é seguro afirmar que boa parte do problema está na execução forçada, pois dada a natureza das operações bancárias e os documentos usualmente representativos dos seus créditos o processo autônomo de execução (via execução forçada) é o instrumento mais adequado para os bancos fazerem a recuperação de seus créditos e, ainda que em alguns casos tenham eles de propor ações prévias de conhecimento para obter sentenças condenatórias, os Bancos terão de se valer da execução forçada da sentença para efetivo recebimento dos valores devidos.

O spread é a diferença entre a taxa de juros com que os bancos captam seus recursos no mercado financeiro e a taxa de juros paga pelo tomador do crédito. $\mathrm{O}$ spread é composto por impostos, pelo custo do compulsório, pelo lucro ou taxa de retorno do Banco, pelas despesas administrativas e pela taxa de inadimplência. Segundo os dados do Banco Central do Brasil a taxa de inadimplência representava aproximadamente $37,4 \%$ do total do spread para o ano de 2007. Segundo o relatório do Banco Central do Brasil “[...] o componente mais importante para explicar o custo de crédito continua sendo a inadimplência, que tem representado sempre mais de $30 \%$ do total e com tendência crescente, apesar da discreta redução de 38,3\% em 2006 para 37,4\% no ano passado", ${ }^{80}$

A inadimplência é também denominada como o risco de crédito, ou seja, o risco do tomador não pagar ao Banco o seu débito, inadimplindo o contrato. Trata-se do

\footnotetext{
80 cf. Relatório de Economia Bancária e Crédito, 2007, in http://www.bcb.gov.br/PEC/Depep/Spread/relatorio_economia_bancaria_credito2007.pdf.
} 
risco de inadimplência que ocorre em todo e qualquer tipo de contrato. $\mathrm{O}$ risco e a incerteza existem em qualquer transação econômica, conforme vimos acima. Nem sempre as partes de um contrato têm condições de medir este risco. O negócio bancário permite esta mensuração, pois os bancos realizam uma grande quantidade de operações de empréstimo todos os dias e conseguem extrair dados estatísticos com ferramentas financeiras que permitem mensurar o índice de inadimplência nos empréstimos realizados para determinados extratos da sociedade, por exemplo, empresas e pessoas físicas, ou por tipo de operação, financiamento para aquisição de veículo, cheque especial etc..

Um dos componentes que força o aumento da taxa do risco de crédito embutido nos spreads, bem como aumenta o valor das despesas administrativas que também são repassadas aos tomadores de crédito, é a dificuldade do recebimento pela via judicial de valores inadimplidos. Segundo nota técnica do Banco Central do Brasil sobre o assunto: "a morosidade judicial, ao dificultar o recebimento de valores contratados, retrai a atividade de crédito e provoca o aumento dos custos dos financiamentos por meio de dois canais. Primeiro, a insegurança jurídica aumenta as despesas administrativas das instituições financeiras, inflando em especial as áreas de avaliação de risco de crédito e jurídica. Segundo, reduz a certeza de pagamento mesmo numa situação de contratação de garantias, pressionando o prêmio de risco embutido no spread." ${ }^{81}$

E de acordo com Armando Castelar Pinheiro: "como discutido, entre outros, por Aith (2000), Pinheiro e Cabral (2001) e Laeven e Majoni (2003), a ineficiência judicial - envolvendo a morosidade das decisões, o custo de uso da Justiça e o risco embutido na falta de imparcialidade e previsibilidade - é uma causa importante desses altos spreads. Aith estima que de $10 \%$ a $30 \%$ do spread bancário no Brasil se deve à ineficiência do Judiciário. Pinheiro e Cabral mostram que, controlando o efeito da legislação e de diferenças de renda per capita, obtém-se que a qualidade do judiciário afeta significativamente a quantidade de crédito bancário na economia, medida pela razão crédito/PIB. Laeven e Majnoni mostram que, controlando um conjunto de características de

\footnotetext{
${ }^{81}$ cf. Fachada, Figueiredo e Lundberg. "Sistema Judicial e Mercado de Crédito no Brasil” in Nota Técnica do Banco Central do Brasil n. 35, p. 14.
} 
diferentes países, a eficiência do judiciário é, junto com a inflação, o principal determinante das diferenças de spreads entre os 106 países analisados. „82

Em estudo recente sobre o assunto, no qual técnicos do Banco Central do Brasil examinaram o comportamento da margem líquida dos juros (spread bancário) em dezessete países emergentes, concluiu o seguinte: "os resultados indicam que quanto melhor é o ambiente legal de um país, menor é a margem líquida dos juros que os bancos obtêm em suas operações. Esse é um resultado esperado, uma vez que um maior respeito aos direitos de propriedade, uma maior certeza no cumprimento dos contratos e uma maior eficiência do Poder Judiciário aumentam o valor das garantias para os bancos, o que reduz o custo de intermediação financeira. Esse é um resultado robusto, uma vez que em todas as estimações essa variável foi significativa ao menos ao nível de 5\%, mesmo quando incluídas todas as varáveis examinadas. Nesse sentido, no período estudado, se o Brasil tivesse o mesmo ambiente legal que o Chile, as estimações indicam que a margem líquida de juros dos bancos sediados no Brasil reduziria em torno de $14 \%$ ". 83

O componente da inadimplência do spread bancário no Brasil é então influenciado, entre outros motivos, também pela ineficiência do funcionamento da jurisdição, o que inclui a execução forçada, em dar pleno cumprimento aos contratos e recuperar de maneira satisfatória valores inadimplidos. Trata-se de problema institucional que não afeta apenas as partes envolvidas diretamente neste ou naquele litígio, mas toda a sociedade, em razão da oferta de crédito a custos altos, o que gera retração de toda a atividade econômica do país.

Como anotam Fachada, Figueiredo e Lundberg "em decorrência da insegurança dos contratos e do funcionamento deficiente do sistema judicial, o bom tomador de crédito no Brasil arca com um custo extraordinário, independentemente de seu histórico de

\footnotetext{
82 cf. "O Componente Judicial dos Spreads Bancários" in Relatório Banco Central, Economia Bancária e Crédito: avaliação de quatro anos do projeto Juros e Spread Bancário, 2003, p. 34-44: http://www.bcb.gov.br/ftp/rel-economia_bancaria_credito.pdf..

${ }_{83}$ cf. Relatório de Economia Bancária e Crédito, 2007, in http://www.bcb.gov.br/PEC/Depep/Spread/relatorio_economia_bancaria_credito2007.pdf.
} 
crédito e sua capacidade de pagamento. Na prática, esse custo adicional é repartido por toda a sociedade, na forma de aumento do spread e do encolhimento da oferta no crédito." 84

Dadas suas características, a partir de informações financeiras divulgadas ao público, realização de inúmeras transações similares, facilidade na obtenção de dados estatísticos e dependência da utilização da jurisdição estatal como reflexo natural do exercício da suas atividades, o setor bancário é um ótimo campo de pesquisa das relações entre atividade econômica e funcionamento do Poder Judiciário. Deve-se ressaltar que com a abordagem do componente judicial do spread bancário não se pretende atribuir ao Poder Judiciário as mazelas das altas taxas de juros praticadas no Brasil, até porque inúmeros outros fatores, como a política macroeconômica do país, concorrem para sua definição, mas procurar demonstrar que a atuação da jurisdição estatal gera impacto direto e verificável na atividade econômica, o que não pode mais ser ignorado pelos economistas e juristas brasileiros.

\subsubsection{Execução Forçada e Economia: conclusão}

O clássico artigo de Ronald Coase "The Problem of Social Cost", definidor das linhas mestras do desenvolvimento da Análise Econômica do Direito e das Organizações, já alertava que em um ambiente de custos de transação positivos as decisões do Poder Judiciário importam e interferem na alocação eficiente dos recursos econômicos na sociedade.

O Teorema de Coase e o desenvolvimento posterior da Análise Econômica do Direito e das Organizações mostram ainda que os custos das transações econômicas devem ser reduzidos, de forma a incentivar que os particulares negociem seus direitos de propriedade, o que provavelmente resultará em uma solução economicamente mais eficiente do que a solução legal por melhor que seja o Poder Judiciário de uma dada sociedade. $^{85}$

\footnotetext{
${ }^{84}$ cf. "Sistema Judicial e Mercado de Crédito no Brasil" in Nota Técnica do Banco Central do Brasil n. 35, p. 15.

${ }^{85}$ Carlos Alberto de Salles faz um contraponto bastante interessante ao Teorema de Coase e crítica a visão de quem põe a eficiência como o objetivo único de todo o sistema sociopolítico (cf. Execução Judicial em Matéria Ambiental, p.113-125). Não discordamos da visão do Professor Salles, especialmente verdadeira ao se analisar as
} 
Nesse sentido, as normas que estruturam a atuação da jurisdição, ou mais especificamente o sistema processual, influenciam positiva ou negativamente os custos de transação referentes aos contratos que dependem da atuação jurisdicional para se concretizar na prática (enforceability).

O sistema de execução forçada se destina a concretizar contratos, fazendo com que estes produzam efeitos jurídicos, ainda que contra a vontade do inadimplente.

O exercício da execução forçada no Brasil ainda não pode ser considerado suficientemente adequado a garantir a plena recomposição do patrimônio do credor, como se o contrato inadimplido tivesse sido cumprido normalmente, o que resultaria em diminuição dos custos de transação com impacto positivo na atividade econômica do país. De outro lado, é animador que o Estado Brasileiro, nas suas diversas esferas (Ministério da Fazenda, Ministério da Justiça, Banco Central do Brasil, Supremo Tribunal Federal etc.), consciente do problema, venha tomando medidas para modificar o estado das coisas em prol de uma execução forçada mais célere e eficiente.

Nesse contexto estão inseridas a edição da Lei 11.232/2005 que alterou o regime da execução de sentença contendo obrigações de pagar (agora chamado de cumprimento de sentença), e da Lei 11.382/2006, que alterou o processo de execução de títulos executivos extrajudiciais.

Contudo, é sabido que alterações legislativas, embora louváveis, não são suficientes. Estas devem vir acompanhadas de mudanças institucionais bem mais difíceis e complexas de se efetivar, especialmente orientadas a uma gestão mais eficiente do Poder Judiciário e à descoberta de caminhos que possam deflagrar uma mudança cultural que

normas legais destinadas a proteger o meio ambiente ou outros interesses difusos da sociedade, mas isto não impede que reconheçamos a importância de utilizarmos o conceito da eficiência econômica na análise do sistema legal de uma economia de mercado, como o brasileiro, ainda mais ao tratarmos de normas pertinentes ao direito contratual e também das normas de direito processual que visam à sua aplicação. 
traga um novo tipo de postura na atuação de partes, advogados e juízes, informada por um conhecimento mínimo dos problemas econômicos que estão por detrás de boa parte das disputas judiciais.

A nossa análise sobre o instituto da penhora que se desenvolve a seguir surgiu como uma tentativa de contribuição ao melhor funcionamento do sistema de execução forçada. E a constatação da importância e influência do exercício da atividade jurisdicional sobre o desenvolvimento econômico nos motivou ainda mais para a nossa empreitada. E não só isso, ao vislumbrarmos com cada vez maior clareza a relação entre direito e economia e mais especialmente entre processo e economia, passamos a entender também que ao menos alguns institutos processuais, tais como a penhora, poderiam ser estudados sob o enfoque da interação do instituto com o direito material, e também com a realidade social e econômica. Trata-se da análise que procuramos fazer a seguir. 


\section{A PENHORA}

\subsection{Breve análise histórica}

A penhora é dos institutos mais antigos do Direito Processual. Há resquícios de suas origens no Direito Grego antigo, por volta do século IV a.c.. ${ }^{86}$

A análise histórica do instituto, gradualmente concebido pela evolução do direito romano, se torna especialmente interessante e produtiva para o estudioso atual como uma tentativa de contribuir para sua adequada compreensão nos dias de hoje e, dentro do escopo desta dissertação, analisar como a transformação da realidade econômica e social influencia o "modo de ser" da penhora.

Luiz Carlos de Azevedo em obra que disseca a origem histórica da penhora e sua evolução até os dias atuais nos traz algumas referências de institutos que podem ser considerados precursores da penhora atual. Trata da "pignoris capio", ainda do período pré-clássico do direito romano, pela qual em determinadas circunstâncias, sem a intervenção de qualquer autoridade, facultava-se ao credor apoderar-se por suas próprias mãos de bens móveis do devedor de modo a forçá-lo a saldar o débito vencido. E nos ensina que "capio, capis, cepi, captum, capere" significa "apanhar, tomar às mãos, apoderar-se", e "pignus, pignoris" significa "penhor, objeto penhorado, segurança" ${ }^{87}$ Já no período clássico do Direito Romano trata da "missio in bona rei servandae causa" pela qual o pretor, em execução de obrigação imposta por sentença condenatória proferida pelo “iudex" ("actio iudicati”), autorizava o credor a se imitir na posse da totalidade do patrimônio do devedor, independentemente do valor da dívida, como forma de compeli-lo a cumprir a obrigação. Exercia o credor o poder de guarda e custódia dos bens apreendidos para posterior venda conduzida por ele próprio sem a participação de qualquer autoridade estatal, caso o devedor

\footnotetext{
${ }^{86}$ cf. Luiz Carlos de Azevedo (Da penhora, p. 13-23).

${ }^{87}$ id, ibidem, p. 37-38.
} 
não saldasse a dívida em determinado tempo. Verifica-se, assim, que nos períodos pré-clássico e clássico as medidas de apreensão de bens do patrimônio do devedor tinham um caráter preponderantemente coercitivo para forçar o devedor a pagar a dívida. ${ }^{88}$

Sobre o período pós-clássico, nos ensina Luiz Carlos de Azevedo que o processo romano perde muito de suas características privatísticas para se tornar estatal e surge neste período a "pignus ex causa iudicati captum", ou penhora realizada em razão do julgamento, que tinha lugar na execução para pagamento de quantia ${ }^{89}$ e era levada a cabo por funcionários da organização judiciária estatal, os quais penhoravam bens do devedor suficientes à liquidação do débito. ${ }^{90}$

É lógico que não há como estabelecer uma relação direta e imediata entre o sistema de execução do direito romano com o sistema de execução atual, a começar pelo fato de no direito romano ainda se possibilitar a execução contra a própria pessoa do devedor ("manus iniectio"), ${ }^{91}$ especialmente nos seus períodos pré-clássico e clássico. Acrescente-se a isso que a índole daquele sistema era essencialmente privada. Nesse sentido, é importante anotar que o "pignus in causa iudicati captum" gerava um direito real ao credor, equivalente ao penhor convencional, o que não é dado pensar que ocorra no sistema atual em que a penhora se manifesta como um ato de sujeição de determinado bem à ordem estatal, e não diretamente ao credor, embora evidentemente também no seu interesse. ${ }^{92}$ De todo modo,

\footnotetext{
${ }^{88}$ cf. Luiz Carlos de Azevedo (Da penhora, p. 25-56).

${ }^{89}$ Nosso sistema de execução por expropriação (execução forçada) também se originou no direito romano (cf. Cândido Rangel Dinamarco, Execução civil, p. 48).

${ }^{90}$ cf. Luiz Carlos de Azevedo (op.cit., p. 42-56).

${ }^{91}$ Tal como expõe Cândido Rangel Dinamarco:"Como se vê dessa apreciação do direito de Roma em suas diversas fases, a execução ali nem sempre correspondeu, em sua finalidade e nas medidas em que consistia, ao que hoje se entende por execução. No direito e na mentalidade contemporâneos, processo executivo é aquele que se desenvolve mediante agressão estatal ao patrimônio, não à pessoa do obrigado, com o escopo de fazer com que se realize, na prática, o resultado preceituado pelas normas de direito substancial. Na medida em que a execução se fazia sobre a pessoa do devedor, sente-se que o Estado romano não tinha forças para neutralizar o sentimento de vingança que o particular trazia em sua mentalidade ainda impregnada dos velhos valores e dos velhos hábitos. Apenas com seu fortalecimento e mediante a invasão da antiga esfera ilimitada de poderes do índividuo, é que lhe foi possível ir imprimindo caráter publicístico à execução forçada, ou seja, ir pouco a pouco instituindo uma verdadeira execução, através da qual o credor recebesse algo em sua patrimônio e o devedor perdesse algo". (op.cit, p. 49).

${ }^{92}$ Segundo Enrico Tullio Liebman: "É fato que o pignus in causa iudicati captum, introduzido pelo Imperador Antonio Pio no processo extra ordinem (Dig., De re iudicata, 42, I, 31), que foi substituindo paulatinamente a execução patrimonial universal do direito romano mais antigo, dava lugar a direito real, sendo por Justiniano parificado ao penhor convencional (Cod., de praet. pign. 8, 21,2). É verdade também que do pignus in causa
} 
já se vislumbra no direito romano, especialmente no "pignus in causa iudicati captum", 93 a origem da penhora em duas de suas mais marcantes características, ser ato processual de apreensão de bens do devedor com finalidade, ao menos mediata, de satisfazer o credor.

$\mathrm{O}$ direito romano influenciou o direito dos Estados da Europa Ocidental. Tal não foi diferente em Portugal. Luiz Carlos de Azevedo menciona que em 1.211 o Rei Afonso II editou decreto real tratando da execução de dívidas e da penhora, com a finalidade de evitar o arbítrio de execuções conduzidas pelo próprio credor, de forma tal que só o representante da estrutura judiciária pudesse levar a cabo atos de execução, inclusive a penhora. ${ }^{94}$

Tal Lei, assim como outras posteriores sobre execução e penhora, foram incorporadas à primeira compilação legislativa oficial de Portugal, as Ordenações Afonsinas de 1.446, na qual, sempre segundo Luiz Carlos de Azevedo, "o processo de execução já se acha inteiramente estruturado". ${ }^{95}$

As compilações legislativas das Ordenações Manuelinas (1521) e Ordenações Filipinas (1603), com algumas poucas modificações no estilo e no conteúdo, mantiveram a estrutura do processo de execução e da penhora constante das Ordenações Afonsinas. $^{96}$

iudicati se desenvolveu historicamente, até triunfar, a forma de execução por meio de apreensão e alienação de bens determinados do executado, e que por muito tempo o credor que primeiro fizesse a penhora era preferido aos outros (cf. Ord. Fil., Liv. III, Tít. 91, parág. $1^{\circ}$.). Mas, no direito moderno, não há mais vestígio deste suposto direito real que seria constituído como efeito da penhora: da antiga concepção neste sentido sobrevive apenas uma lembrança no nome do ato". (cf. Processo de execução, p. 125-126). Cabe apenas anotar que Liebman escreveu tal comentário à luz do CPC de 1939 que não previa o direito de preferência do credor de fazer a primeira penhora; hoje, contudo, tal direito de preferência vige no sistema processual (CPC, art. 612) mas não é visto pela doutrina como uma regressão à concepção da penhora como um direito real. Neste sentido: Araken de Assis (Manual da execução, p. 588/591) e Luiz Carlos de Azevedo (Da penhora, p. 119/130).

${ }^{93}$ Segundo Cândido Rangel Dinamarco, "o procedimento do pignus in causa judicati captum ... representa a origem remota de nossa execução por expropriação”. (cf. Execução Civil, p. 48).

${ }^{94}$ cf. Luiz Carlos de Azevedo (Da Penhora, p. 70-71).

${ }^{95}$ id., ibidem, p. 76.

${ }^{96}$ id. ibidem, p. 78. 
O nosso interesse é analisar, ainda que brevemente, a penhora nas Ordenações Filipinas, que teve vigência no Brasil por três séculos, ${ }^{97}$ durante todo o período colonial e mais dezenas de anos após a independência do país até que fossem editadas novas Leis sobre as diversas matérias por aquela reguladas.

No que se refere às execuções cíveis, mais especificamente ao instituto da penhora, as Ordenações Filipinas, por seu livro III, vigorou no Brasil para as causas comerciais até 1850 , as quais passaram ser a reguladas de acordo com o Regulamento n. 737 de 25 de novembro de 1850, vinculado ao Código Comercial do mesmo ano, e até 1886 para as causas cíveis, que passaram a ser reguladas em matéria de execução pelo referido Regulamento n. 737, por força da Lei n. 3.272 de 5 de outubro de 1885, e seu Regulamento, aprovado pelo Decreto n. 9549 de 23 de janeiro de $1886 .{ }^{98}$

A penhora é regulada nas Ordenações Filipinas em seu livro III, no Título 86, dedicado às "execuções que se fazem geralmente pelas sentenças".

Diz as Ordenações Filipinas no intróito do Título 86 que para a execução de sentença que condene ao pagamento de "alguma quantidade de dinheiro, pão, vinho, azeite, ou qualquer cousa que se costuma contar, pesar ou medir, será o condenado requerido, para que pague o contido na sentença, ou dê penhores bastantes à condenação". E mais adiante: "E se logo não pagar o contido na sentença não lhe será mais dado tempo, nem espaço algum; antes será logo feita a penhora em tantos de seus bens, que bastem para a dita condenação".

A execução se iniciava então com a intimação do condenado/executado para que pagasse sua dívida ou oferecesse bens à penhora suficientes para suportar a condenação. E se o condenado não pagasse de imediato o Oficial deveria proceder à penhora.

\footnotetext{
${ }^{97}$ id., ibidem, p. 78.

${ }^{98}$ cf. Luiz Carlos de Azevedo (Da Penhora, p. 90).
} 
Caso o condenado estivesse presente ao tempo da penhora, deveria o Oficial perguntar-lhe se possuía bens móveis e se a resposta fosse positiva, deveria o condenado mostrá-los para que no outro dia se lavrasse o auto de penhora sobre os bens indicados. Se o condenado dissesse que não tinha bens, não os mostrasse, não os apresentasse no dia seguinte desembargados ou não fossem os bens apresentados suficientes, a penhora deveria ser feita em quaisquer bens móveis, que o credor mostrasse ou nos bens de raiz, sem que o condenado pudesse alegar que tinha outros bens móveis sobre os quais a penhora deveria por primeiro incidir (Liv. III, Tít. 86, n. 7).

Se o condenado estivesse ausente ao tempo da penhora, o Escrivão presente deveria se informar na casa do condenado ou na vizinhança se o condenado tinha bens, fazendo preferencialmente a penhora nos bens móveis e, caso não se fizesse possível, nos bens de raiz (Liv. III, Tít. 86, n. 8).

Desde já, é importante notar que as Ordenações Filipinas determinava que a penhora fosse feita preferencialmente sobre bens móveis, e apenas se esta não se fizesse possível ou fosse insuficiente para suportar a execução, se fizesse sobre os bens de raiz.

Eram impenhoráveis os cavalos, armas, livros, vestidos dos corpos, dos fidalgos, cavaleiros e desembargadores, bem como de suas mulheres, "havendo respeito ao que cada um é necessário para seu serviço e uso, conforme a qualidade de suas pessoas, posto que outros bens não tenham". Seriam, contudo, aqueles bens penhoráveis, caso não fossem necessários e não houvesse outros bens móveis e imóveis disponíveis; e também o seriam, sem qualquer exceção, nos casos que envolvessem a prática por aqueles de "roubos e malfeitorias" (Liv. III, Tít. 86, n. 23).

Eram impenhoráveis também os (a) cavalos e armas daqueles que continuamente prestavam serviço ao Reino, bem como os (b) bois de arado e sementes dos Lavradores necessários à atividade da lavoura (Liv. III, Tít. 86, n. 24). 
E caso não fossem localizados bens em nome do condenado/executado, conforme norma do Livro IV, título 76, n. 1, deveria ser este último "preso e retido na cadeia até que pague". Conforme ensina Luiz Carlos de Azevedo: "a ordem de prisão alcançava, assim, tanto devedores dolosos, que escondiam seus bens, tanto outros, que retardavam a execução, 'tolhendo o penhor ao porteiro', como aqueles devedores de boa fé, que simplesmente não pagavam, nem ofereciam bens, porque não tinham como fazê-lo; e nem gozavam de privilégio capaz de livrá-los do cárcere". ${ }^{99}$ Verifica-se, assim, que apesar de, a princípio, a execução incidir sobre o patrimônio do devedor, caso este por qualquer motivo não tivesse bens deveria ser punido pessoalmente. Esta norma só foi abrandada com o Alvará de 18 de agosto de 1774, Lei Portuguesa que livrou os devedores insolventes de boa-fé da pena de prisão, providência que segundo o já inúmeras vezes citado Professor Azevedo "acabou por beneficiar a todos os devedores civis, de maneira indistinta, já que a partir de então, tal modo de proceder caiu em desuso". ${ }^{100} 101$

Voltando ao modo de proceder da penhora, os bens penhorados, móveis ou imóveis, eram desapossados do condenado/executado que não poderia receber os frutos advindos dos bens penhorados (Liv. III, Tít. 86, n. 1). O condenado/executado poderia opor embargos no prazo de 6 dias do desapossamento dos bens penhorados (Liv. III, Tít. 86, n. $1)^{102}$

Vindo os embargos "em tempo devido", a execução prosseguia normalmente até a liquidação do bem penhorado, sendo certo que o vencedor só poderia

\footnotetext{
${ }^{99}$ Observa ainda o Professor Azevedo que na época da Monarquia Absoluta havia privilégios aos súditos de nobre estirpe, membros do clero, altos dignitários e funcionários do Reino; os quais pagavam multas ou eram no máximo degradados para as Colônias portuguesas, se eximindo de sanções mais severas. Estes privilégios também se estendiam à forma de proceder a penhora, como, por exemplo, a obrigação do Oficial de procurar penhorar primeiro bens de fora das casas dos fidalgos, não lhe sendo permitido no início da diligência entrar no interior da residência (Liv. III, Tít. 86, n. 12) (Da penhora p, 83-84).

100 id., ibidem, p. 84.

${ }^{101}$ Nessa linha, vale destacar decisão da mais alta Corte Portuguesa da época, a Casa da Suplicação, na forma dos chamados assentos (livr. 2, fls. 122 vers.), de 18 de agosto de 1774: "A lei, que desobrigou de prisão os impossibilitados sem fraude para pagarem a seus credores comprehendeu igualmente os devedores, que se acharão presos ao tempo de sua publicação por dívidas cíveis ou crime." (cf. Cândido Mendes de Almeida, Auxiliar jurídico, apêndice às ordenações filipinas, v. I, p. 265).

${ }^{102}$ Vale destacar, neste ponto, o seguinte estilo da Casa da Suplicação: "33.Execução quando se faz, tem o condemnado, sendo requerido, seis dias para vir com seus embargos Ord. Liv. 3 tit. 87 in principio: estes se entende que hão de correr, feita a penhora, e desapossado o Réo dos penhores pela Ord. Liv. 3 tit. 86 parag. 2.” ( id., ibidem, p. 59).
} 
levantar o dinheiro se oferecesse fiança ao Juízo, de forma a garantir a devida restituição ao condenado, no caso deste ser vitorioso nos embargos (Liv. III, Tít. 86, n. 3). Caso os embargos opostos pelo condenado/executado impedissem que a execução acabasse em três meses, aquele seria preso, "conforme a qualidade da sua pessoa", ${ }^{103}$ até que a execução fosse finda (Liv. III, Tít. 86, n. 18).

No curso da execução, dada a sentença, se o condenado/executado alienasse bens móveis em prejuízo do devedor, seria aquele preso até que a dívida fosse paga. E mesmo que tivesse bens imóveis, se fosse casado, o condenado seria preso até que trouxesse de volta os bens móveis, de forma a não prejudicar indevidamente a meação da mulher (Liv. III, Tít. 86, n. 13). ${ }^{104}$

Como dado curioso, a indicar a existência de problemas burocráticos e estruturais que ocorrem usualmente ainda hoje, as Ordenações Filipinas previa a punição de suspensão do Oficial de Justiça que não cumprisse o mandado de penhora no prazo de 5 (cinco) dias (Liv. III, Tít. 86, n. 20).

E não é mera coincidência que no Regulamento n. 737 de 1850 (art. 514), a legislação processual que sucedeu as Ordenações Filipinas no Brasil, e no Código de Processo Civil de 1939 (art. 928), estatuto processual que por sua vez sucedeu o Regulamento n. 737 após breve vigência dos Códigos de Processo Estaduais, ${ }^{105}$ havia disposições semelhantes às constantes nas Ordenações Filipinas sobre a aplicabilidade de punições ao

\footnotetext{
${ }^{103}$ Neste termo mais uma vez se verifica a discriminação gritante respaldada na Lei.

104 Sobre a nossa conhecida fraude à execução, tratada nas Ordenações Filipinas, embora não sob este termo, destaquem-se os seguintes arestos da Casa de Suplicação abordando casos que não são incomuns de ocorrer nos tempos atuais: "Sendo fraudulenta a alheação de bens, pode o exeqüente penhorá-los embora no poder de terceiro, independente de ação ordinária revocatória" (Aresto de 17 de abril de 1750 compilado por Cândido Mendes de Almeida, Auxiliar Jurídico, Apêndice às Ordenações Filipinas, v.I, p. 389) e "a venda de bens depois de começada huma acção, não tendo o devedor outros meios de solver sua obrigação, reputa-se simulada e dolosa"(Aresto de 26 de fevereiro de 1737 compilado por Cândido Mendes de Almeida, Auxiliar Jurídico, Apêndice às Ordenações Filipinas, v. I, p. 384).

${ }^{105}$ Cumpre consignar que a partir de 1905, com base na Constituição Federal de 1891, alguns estados passaram a editar seus próprios Códigos de Processo Civil, cuja vigência perdurou até a edição do Código de Processo Civil de 1939, de âmbito nacional. Nos estados em que não foram editados os Códigos de Processo próprios vigorou o Regulamento n. 737 até que entrasse em vigor o Código de Processo Civil de 1939, o que aconteceu em 1940. No que se refere à execução e à penhora, os Códigos de Processo Estaduais editados pouco inovaram em relação às disposições do Regulamento n. 737. (cf. Luiz Carlos de Azevedo, Da penhora p. 94).
} 
Oficial de Justiça que não cumprisse o mandado de penhora em 5 dias. $\mathrm{O}$ fato é que a estrutura básica do processo de execução das Ordenações Filipinas foi reproduzida no Regulamento n. 737 e no Código de Processo Civil de 1939.

A penhora continuou a ser instituto fundamental do sistema de execução, mantendo suas características essenciais de ser o ato de apreensão de bens do devedor com a finalidade de, no curso da execução, propiciar a satisfação do credor.

Mas a sociedade brasileira modificou-se profundamente desde as Ordenações Filipinas até hoje. E ainda, a economia brasileira neste largo período histórico foi gradualmente se modificando, se desenvolvendo e tornando-se bem mais complexa. Tais mudanças logicamente se refletiram na legislação.

A primeira e mais evidente constatação que se deve fazer é sobre o gradual desuso e a revogação de disposições legais que concediam privilégios legais a determinadas pessoas, em função de títulos e posição social, bem como aquelas que estabeleciam a pena de prisão para devedores insolventes. Como visto acima, muito tempo antes do Regulamento n. 737, lei portuguesa de 1774 já livrava os devedores insolventes de boa-fé da pena de prisão, modificando as Ordenações Filipinas. ${ }^{106}$ Nas Ordenações Filipinas, os fidalgos, cavaleiros e desembargadores tinham determinados privilégios, especialmente no que toca à impenhorabilidade de bens (Liv. III, Tít. 86, n. 23). No Regulamento n. 737, apenas os vencimentos de magistrados, empregados públicos e de militares eram protegidos pela impenhorabilidade (art. 529), proteção só estendida aos salários dos cidadãos em geral no Código de Processo Civil de 1939 (art. 942). ${ }^{107}$

\footnotetext{
${ }^{106}$ Embora cumpra consignar que no Regulamento n. 737 caso o executado escondesse os bens para não serem penhorados, ou deixar de possuí-los por dolo seria preso até que entregasse os bens ou o seu equivalente, ou até um ano se antes não entregar (art. 525). Sobre este dispositivo, vale citar interessante decisão da época que distingue a situação nele disposta e a prisão por dívida: "O artigo supra não foi subrogado pelo art. 327 do Código Penal, por isso que não decreta a prisão por dívida, mas sim pune o dolo ou fraude do executado para prejudicar seus credores (Acc. do Trib. de Just. de SP de 8/3/1895. Gazeta Jurídica, vol. 8º, pág. 55; Acc. do STF de 25/2/1893; Gazeta Jurídica cit. Vol. 2., pág. 74)" (cf. Antônio Bento de Faria em nota ao art. 525 do Regulamento n. 737, Código Commercial Brasileiro Anotado).

${ }^{107}$ Julgado do extinto Tribunal de Alçada Civil de São Paulo, de 9 de setembro de 1970, estende o conceito de salário para contemplar também a impenhorabilidade do pro labore ou retirada mensal do sócio (RT 419/196). Ver também julgado do extinto $1^{\circ}$. Tribunal de Alçada Civil de São Paulo, de 2 de maio de 1973, reconhecendo a
} 
Sobre a ordem legal de preferência na realização da penhora, verifica-se que nas Ordenações Filipinas, a penhora deveria ser preferencialmente feita sobre bens móveis e, só na ausência destes, sobre bens de raiz (Liv. III, Tít. 86, n. 8). No Regulamento n. 737, como reflexo de uma economia mais complexa, a ordem de preferência passou a ser a seguinte: a) dinheiro, ouro, prata e pedras preciosas, b) títulos da dívida pública, e quaisquer papéis de crédito do Governo, c) móveis e semoventes, d) bens de raiz ou imóveis (neste rol, consideradas as embarcações) e e) direitos e ações (art. 512). No Código de Processo Civil de 1939, foi mantida praticamente a mesma ordem do Regulamento n. 737, com a inclusão de "papéis de crédito que tenham cotação em bolsa" na mesma classe dos títulos da dívida pública (art. 930).

É importante consignar também que a partir do Regulamento n. 737 começam a haver disposições legais que contemplam expressamente formas diversas de realização da penhora, conforme a especificidade do bem a ser penhorado. Tratava, assim, o Regulamento n. 737 da penhora de dinheiro do executado em mãos de terceiro, que só era possível se o terceiro confessasse não ser o titular da quantia em dinheiro, mas sim o executado, figurando o terceiro como depositário da penhora, caso não entregasse em 3 dias o dinheiro ao Juízo (arts. 521 e 522). Máquinas, escravos, bois e cavalos empregados nas fábricas de mineração, açúcar e lavouras de cana, só poderiam ser penhorados em conjunto com as fábricas (art. 531), esboçando-se, desde então, uma nítida preocupação de a penhora não afetar a continuidade da atividade produtiva. Admitia-se a penhora do quinhão do devedor co-proprietário de navio, sendo que a livre navegação só poderia ocorrer se os demais proprietários do navio oferecessem fiança idônea (art. 499), de maneira a garantir-se a integridade da penhora.

Mas é no Código de Processo Civil de 1939 que se verifica de maneira mais contundente a preocupação do Legislador de procurar adaptar a forma ou o método de realização da penhora com a especificidade dos bens a serem penhorados. Diante

impenhorabilidade de verbas trabalhistas depositadas em favor do executado em reclamação trabalhista da qual é Autor (RT 458/120). 
de uma complexidade cada vez maior dos bens passiveis de penhora exigiam-se formas diferenciadas de apreensão.

$\mathrm{O}$ art. 931 procurava definir o que eram "direitos e ações, para os efeitos da penhora": (a) dívidas ativas, vencidas ou vincendas, constantes de documentos; (b) as ações reais, reipersecutórias, ou pessoais, para cobrança de dívidas; (c) as quotas de herança em autos de inventário e partilha e (d) os fundo líquidos que possua o executado em sociedade comercial ou civil. ${ }^{108} \mathrm{E}$ nos termos do art. 938, estabelecia-se que o exeqüente se sub-rogava do direito penhorado até a concorrência de seu crédito.

No art. 936 tratava-se da forma de realização da penhora sobre direito objeto de processo judicial, a qual deveria ser feita no rosto dos autos do processo, "para que se torne efetiva nas coisas ou direitos que forem adjudicados ao executado ou a ele possam caber".

$\mathrm{O}$ art. 937 regulava a penhora sobre dinheiro do devedor em mãos de terceiro, prevendo a notificação do terceiro para que este não pagasse ao executado, embora o objeto desta penhora, em verdade, não fosse exatamente o dinheiro do executado em mãos de terceiro, mas o crédito do executado perante terceiro, ${ }^{109}$ tal como regula hoje o art. 671 do Código de Processo Civil em vigor.

O art. 939 do Código de Processo Civil de 1939 tratava também da penhora sobre título de crédito, cuja realização se dava pela notificação ao devedor do executado para não pagá-lo, e aos terceiros interessados, por edital, diferentemente da regulação atual que prevê a efetiva apreensão do título para aperfeiçoamento da penhora (art. 672).

\footnotetext{
${ }^{108}$ Embora anotasse José Frederico Marques que tal rol de bens e direitos era exemplificativa, "pois que outras ações e direitos ali não previstos podem também ser objeto de penhora". (cf. Instituições de Direito Processual Civil, vol V, 1960, p. 199). No mesmo sentido, Pontes de Miranda (Comentários ao Código de Processo Civil, tomo XIII, p. 238).

${ }^{109}$ Como anotava Pontes de Miranda à época esta penhora era majoritariamente aplicada a créditos (id, ibidem, p. 252).
} 
O art. 941 do Código de Processo Civil de 1939, em redação praticamente idêntica à atual (art. 675), estabelecia que no caso de "penhora de dívidas de dinheiro a juros", ou seja, de crédito do executado gerado por empréstimo a juros, "de direito a rendas" ou de "prestações periódicas", o exeqüente poderia levantar tais remunerações, abatendo da dívida, conforme as regras da imputação de pagamento.

E em capítulo sobre a "a administração dos bens penhorados", o Código de Processo Civil de 1939 passou a tratar de um outro tipo de penhora, aquela feita sobre "vias férreas, linhas telefônicas e telegráficas, empresas de luz, água e outras de serviço público, ou dos materiais empregados em seu funcionamento", que deveria ser feita sem prejuízo da regularidade dos serviços e deveria ter como depositário da penhora um dos administradores dos referidos equipamentos (art. 953).

$\mathrm{O}$ art. 954 por sua vez previa a possibilidade de penhora sobre "estabelecimento comercial ou industrial ou em propriedade agrícola, sementeiras ou plantações", sendo que a forma de administração da penhora deveria ser determinada pelo juiz, com o fito de se evitar qualquer dano à produção ou ao comércio.

Verifica-se, assim, a partir desta breve análise do Código de Processo Civil de 1939, que a forma ou o método de realização da penhora passava a variar e a se adaptar, conforme as especificidades dos bens objeto de penhora, cuja maior variedade e complexidade espelhavam uma sociedade e uma economia também mais complexas.

Nesse sentido, o Código de Processo Civil de 1939 traz de modo mais nítido a preocupação de adaptar o instituto processual destinado a apreender bens do devedor às características cada vez mais variadas daqueles bens, visto que o ato de apreensão deve ser condizente com o "modo de ser" do bem a ser apreendido.

Percebe-se uma nítida tendência de procurar compatibilizar o instituto herdado do Direito Português às mudanças sociais e econômicas da época, sem perder-se de vista que no percurso histórico de vigência das Ordenações Filipinas no Brasil até 
o Código de Processo Civil de 1939 a penhora continuava a manter sua característica essencial de ser o ato judicial de apreensão de bens do devedor com a finalidade última de satisfazer o credor por meio dos atos processuais subseqüentes.

É de se anotar, contudo, que ao longo deste período passou-se gradualmente a admitir-se o depósito dos bens penhorados em mãos do próprio devedor, o que era impensável de se imaginar na concepção original do instituto.

No regime das Ordenações Filipinas, a apreensão acarretava o desapossamento efetivo do bem das mãos do devedor que ficava sob a guarda de terceira pessoa. A partir do Regulamento n. 737, passa-se a prescindir da apreensão efetiva ou real, na medida em que passa a ser aceito o depósito do bem em mãos do próprio devedor, ${ }^{110}$ desde que convindo o credor, o que com o passar dos anos, foi se tornando cada vez mais comum. ${ }^{111}$ Com a edição do Código de Processo Civil de 1939, manteve-se a regra de que o depósito seria feito em mãos do executado, desde que convindo o exeqüente. Na prática, ao menos no caso de penhora de móveis, semoventes e imóveis o executado usualmente era nomeado depositário e eventual contrariedade do exeqüente deveria ser fundamentada e dependeria da análise do Juiz. ${ }^{112}$

\footnotetext{
${ }^{110}$ Segundo Antônio Bento de Faria: "Convindo as partes podem os bens ser depositados em mão do devedor, do credor ou de terceira pessoa por este indicada. É o que se infere do art. 528 que manda applicar á penhora o art. 328. O executado somente pode ficar como depositário dos bens penhorados, si a isso anuir o exequente (arts. 328 comb. com art.528) (Acc. do Trib. de São Paulo, de 4 de dezembro de 1905; S.Paulo Judiciário, vol. 9, pág. 411); em caso de divergência a nomeação compete ao juiz que deverá remover o depositário negligente (Acc. da $1^{a}$. Cam.da Corte de Appel., de 15 de abril de 1909; Rev.de Direito, vol 12, p. 343)". (cf. Código Commercial Brasileiro Anotado, p. 887). O art. 328 do Regulamento n. 737 que trata do embargo dispõe o seguinte: "Feito o embargo, serão os bens depositados em poder de terceira pessoa que assignará o auto respectivo como depositário judicial. Se não houver terceira pessoa será depositário o devedor se o credor convier, ou o credor ou qualquer pessoa que elle indicar sob sob sua responsabilidade se o devedor consentir".

${ }^{111}$ Segundo Luiz Carlos de Azevedo: "Era, com efeito, o que vinha sucedendo nos casos concretos, segundo ilustram decisões da época e os próprios códigos estaduais, que então vinham sendo promulgados. Vale dizer, alterara-se a regra, de modo que, em princípio, os bens continuavam em poder do executado; só quando o exeqüente não concordava, ou quando fosse conveniente ao interesse da Justiça, é que iam ter ao depositário público, ou particular. Ademais, a recusa do credor necessitava fundamento, não bastando o seu simples ato de vontade para que os bens, após a penhora, fossem apreendidos e removidos para outro local. É o que acontece também no regime atual." (cf. Da penhora p. 98).

${ }^{112}$ Conforme José Frederico Marques citando Osvaldo Pinto do Amaral: "Ficará como depositário o executado quando nisso convenha o exeqüente, em qualquer caso; tratando-se, porém, de penhora de móveis, semoventes e imóveis, o executado será depositário se ao juiz parecer conveniente, embora com oposição do exeqüente". (cf. Instituições de Direito Processual Civil, vol V, 1960, p. 205).
} 
O Código de Processo Civil de 1973 manteve o regime da penhora do Código de Processo Civil de 1939, com algumas alterações, dentre as quais se destaca a reintrodução, porque havia vigido nas Ordenações Filipinas, ${ }^{113}$ do direito de preferência sobre os bens penhorados para o credor que fizer a primeira penhora (CPC, art. 612). ${ }^{114}$ A Lei n. 11.382 de 6 de dezembro de 2006 procurou atualizar o Código de Processo Civil de 1973 às sensíveis mudanças sociais e econômicas, pelas quais o Brasil passou nos mais de trinta anos de promulgação daquele diploma legal. É o que se passa a analisar, o instituto da penhora no regime atual dentro do escopo fixado na introdução deste trabalho.

\subsection{A responsabilidade patrimonial}

Já foi dito neste trabalho (item 2.4.) que a execução forçada é o meio pelo qual o Estado-Juiz invade o patrimônio do devedor de obrigação de pagar e, independentemente da vontade deste, expropria seus bens em favor do credor.

O fundamento para esta atuação estatal coercitiva sobre o patrimônio do devedor reside na função e no poder do Estado de garantir a aplicação e eficácia das normas de direito material, ainda que estas não sejam espontaneamente cumpridas pelo devedor, dando ao credor a mesma condição que ele teria se as referidas normas tivessem sido observadas. Ou seja, havendo o inadimplemento de uma obrigação, reconhecida por sentença ou instituída com base em título executivo extrajudicial, o Estado-Juiz atuará coercitivamente para que o direito material seja atuado e o credor satisfeito.

Se no passado esta atuação estatal poderia se fazer sobre a própria pessoa do devedor, que respondia com seu corpo pelo inadimplemento de obrigações de pagar por ele assumidas, modernamente a responsabilidade do devedor incide sobre seu patrimônio. Trata-se da responsabilidade patrimonial, "caracterizada pela sujeitabilidade do patrimônio de

\footnotetext{
113 cf. José Frederico Marques (cf. Instituições de direito processual civil, vol V, p. 184).

114 cf. Araken de Assis (Manual da execução, p. 588/589)
} 
alguém às medidas executivas destinadas à atuação da vontade concreta do direito material". 115

Quer dizer, inadimplida a obrigação de pagar pelo devedor, decorrente da inobservância das normas de direito material, caberá ao credor provocar o Estado-Juiz para que este utilize seu poder coercitivo para submeter o patrimônio do devedor ou outro responsável à satisfação do credor, fazendo valer o princípio da responsabilidade patrimonial.

Na lição clássica de Liebman, citada por Luiz Carlos de Azevedo, "a responsabilidade, ao invés de ser elemento da relação obrigacional, ..., é o vínculo de direito público processual, consistente na sujeição dos bens do devedor a serem destinados a satisfazer o credor, que não recebeu a prestação devida, por meio da realização da sanção, por parte do órgão judiciário". Seguindo na explicação do Professor Azevedo: “ Na verdade, toda a questão se situa na distinção que deve haver entre o direito (objetivo) material e o direito processual. Quando se trata do primeiro, pode-se falar em obrigação, a qual corresponde um direito. Mas, quanto ao segundo, já não se cuida mais de obrigações e direitos de uma parte com outra, mas do poder do órgão ao qual é confiada a atuação da norma material, do juiz e do oficial encarregado da execução. Agora, dada a função exercida pelo juiz e pelos órgãos delegados, ao poder destes não mais corresponde uma obrigação da parte, no sentido material que a palavra comporta, mas um estado de sujeição; se antes o devedor podia cumprir a obrigação, terá doravante de se sujeitar e de se submeter ao processo de execução, desde que neste estejam atendidos todos os seus pressupostos legais."116

Nessa linha, o conceito de obrigação se situa no plano do direito material e o conceito de responsabilidade patrimonial no plano do direito processual. ${ }^{117}$ Por isso, o responsável pela execução, o sujeito a ter seu patrimônio excutido para satisfazer o credor pode ser pessoa diversa da que contraiu a obrigação. Tal como, por exemplo, o

\footnotetext{
115 cf. Cândido Rangel Dinamarco (Execução civil, p. 241).

116 cf. Da penhora, p. 106/107.

${ }^{117}$ Ver também Cândido Rangel Dinamarco (op.cit., p. 246/247).
} 
cônjuge pela dívida contraída por seu consorte (CPC, art. 592, IV). ${ }^{118} \mathrm{Na}$ seara tributária, também em hipóteses específicas, o sócio-administrador responde pela dívida da sociedade.

Mas a regra geral decorrente do princípio da responsabilidade patrimonial ou executiva, é a de que o devedor responde pela execução. O objeto desta responsabilidade são todos os bens constantes do patrimônio do devedor (CPC, art. 591).

As exceções à regra geral são as seguintes:

a) há certos tipos de bens que são excluídos da responsabilidade executiva, considerados inexpropriáveis por força de Lei, os chamados bens impenhoráveis e

b) há bens que não são do devedor no momento da execução e que

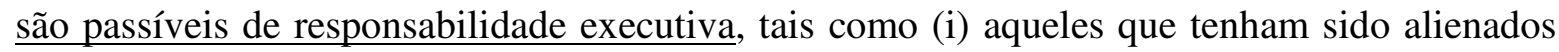
em fraude contra credores ou em fraude à execução, (ii) aqueles hipotecados ou penhorados ${ }^{119} \mathrm{em}$ favor do credor, mas alienados a terceiros e (iii) aqueles integrantes do patrimônio de terceiros alheios à obrigação, mas que têm responsabilidade executiva por ato de vontade ${ }^{120}$ ou por força de determinação legal. ${ }^{121}$

\footnotetext{
118 cf. Araken de Assis (Manual da execução, p. 209)

${ }^{119}$ Conforme veremos, a alienação de bem penhorado pelo executado a terceiro é ato ineficaz perante o juízo da execução.

${ }^{120}$ Conforme acórdão do extinto Tribunal de Alçada do Rio Grande do Sul, de 18 de dezembro de 1973, cuja lição permanece válida até hoje: “ ..., válida a penhora e a questão de quem seja o dono dos bens penhorados é, para o exeqüente, 'res inter allios': alguém pode dar em penhora bens seus para segurar o juízo em discussão de terceiro". (RT 461/256).

${ }^{121}$ Extraímos tais exceções da obra de Cândido Rangel Dinamarco e as adaptamos a este trabalho. (Execução civil, p. 243-245).
} 


\subsection{O conceito e a função da penhora}

Feita esta necessária explanação sobre o princípio da responsabilidade patrimonial que é o pressuposto lógico do funcionamento do sistema de execução forçada utilizada pelo Estado-Juiz para fazer valer o direito material nos casos de inadimplemento de obrigação de pagar, cabe tratarmos do conceito e da função da penhora em tal sistema.

Barbosa Moreira define a penhora como "o ato pelo qual se apreendem bens para empregá-los, de maneira direta ou indireta, na satisfação do crédito exeqüendo". ${ }^{122}{ }^{123}$ Segundo Araken de Assis, citando julgado do Superior Tribunal de Justiça (RESP n. 9.731-CE, Rel. Min. Eduardo Ribeiro) "a penhora constitui 'ato específico de intromissão do Estado na esfera jurídica' do obrigado, 'mediante a apreensão material, direta ou indireta, de bens constantes no patrimônio do devedor". ${ }^{124}$

A essência do ato de penhora é constituir-se apreensão de bens; na dicção do art. 664, caput, do Código de Processo Civil "considerar-se-á feita a penhora mediante a apreensão e o depósito dos bens”. Esta apreensão ocorre para se obter a futura satisfação do credor. Tal como realçado na análise histórica que fizemos do instituto, ainda que sua natureza jurídica tivesse sido observada sob enfoques diversos e a forma de sua realização houvesse variado, não se pode negar que a marca distintiva da penhora ao longo da história foi a de ser fundamentalmente um ato de apreensão de bens do executado realizado com a finalidade de propiciar no curso da execução a satisfação do exequente.

De acordo com Araken de Assis: "conquanto providência de natureza instrumental, no sentido de que é etapa para atos ulteriores, a penhora representa ato executivo e, portanto, ato dotado de eficácia satisfativa. Criticando aqueles que valorizam

\footnotetext{
122 cf. O Novo processo civil brasileiro, p. 235.

${ }^{123}$ No mesmo sentido é acórdão do Tribunal de Justiça de São Paulo: "Penhora é ato de constrição judicial. O Estado, através do juiz, apreende bens, para sujeitá-los a execução em benefício do credor”. (RT 485/89).

${ }^{124}$ cf. Manual da Execução, p. 591.
} 
elemento 'cautelar' (rectius: conservativo) do ato, Tito Carnacini observa que, às evidências, 'o fim imediato não é conservar', na penhora, o que seria próprio da pretensão à segurança, e sim transformar bens no objeto da prestação devida."125

A penhora visa a tornar concreta a responsabilidade patrimonial genérica $^{126}$ do executado, sujeitando bens determinados ao juízo da execução, orientados à satisfação do exequente. ${ }^{127} \mathrm{~A}$ função conservativa da penhora é então conseqüência de sua função satisfativa, uma vez que os bens penhorados devem ser conservados íntegros até que os atos de expropriação ocorram.

Nesse sentido, com a realização da penhora o exequente pretende, por meio dos atos ulteriores próprios à execução forçada, transformar o bem em dinheiro (alienação) ou convertê-lo diretamente ao seu patrimônio (adjudicação) de forma que sua pretensão seja satisfeita, momento em que a tutela jurisdicional é atingida. É, assim, equivocado, tal como muitas vezes ocorre na prática forense, ver o instituto da penhora como apenas e tão somente uma garantia do Juízo da execução.

Tal visão possivelmente está atrelada à longa tradição do Direito Processual Brasileiro, que se estendeu das Ordenações Filipinas até o Código de Processo Civil de 1973, antes da reforma, de colocar a penhora como uma etapa prévia à impugnação judicial da execução via embargos do devedor. Como os embargos tinham efeito suspensivo automático da execução, era quase intuitivo ver a penhora como uma mera garantia a possibilitar uma nova discussão judicial que se iniciaria (e se "eternizaria") com os embargos. Nesse contexto, a função conservativa da penhora se sobrelevava sobre sua função essencial que é satisfativa.

\footnotetext{
125 cf. Manual dar execução, p. 590.

${ }^{126} \mathrm{Na}$ lição de Enrico Tullio Liebman: “ Esta responsabilidade, que abrange genericamente todos os bens do executado ou dos terceiros secundariamente responsáveis, se concentra e se imprime pela penhora com energia reforçada nos bens apreendidos, para não soltá-los mais e levá-los tal como estão ao ato de desapropriação. A penhora escolhe, pois, e destina definitivamente, no patrimônio do responsável, os bens que deverão servir à satisfação do exeqüente" (Processo de execução, p. 123).

127 cf. Luiz Carlos de Azevedo (Da penhora, p. 119).
} 
Com a edição das Leis n. 11.232/2005 e n. 11.382/2006, a função satisfativa da penhora voltou a ser valorizada, pois, no caso da execução de sentenças, acabouse com os embargos e instituiu-se o procedimento mais simples da impugnação, sem efeito suspensivo automático da execução; e no caso da execução de títulos extrajudiciais, da mesma forma retirou-se o efeito suspensivo automático decorrente do ajuizamento dos embargos do devedor e, ainda, se estabeleceu que o oferecimento dos embargos não está vinculado à prévia realização da penhora, embora a concessão do efeito suspensivo esteja. Nos dois casos, a suspensão da execução passa a ser medida excepcional. No caso dos títulos extrajudiciais, a penhora sequer é uma condição necessária para a impugnação judicial via embargos da execução.

Fica claro então que a finalidade da penhora é possibilitar a satisfação do credor, via sujeição de bens determinados ao Juízo da execução, para que os atos de expropriação possam ter seqüência, e não servir como uma mera garantia a permitir uma discussão judicial futura, até porque esta é ocasional e não se insere no âmbito da atividade jurisdicional executiva, pois depende da provocação do executado via ação de conhecimento. $^{128}$

A função conservativa por sua vez é decorrência lógica da função satisfativa, na medida em que é necessário conservar intactos os bens penhorados até o momento da expropriação, a qual usualmente depende de prévia avaliação e outros atos preparatórios da alienação/adjudicação.

\footnotetext{
${ }^{128}$ Cabe ressaltar que a Doutrina vem atribuindo à impugnação ao cumprimento de sentença a natureza de ação de conhecimento, tal como os embargos do devedor cabíveis na execução de título extrajudicial. Nesse sentido, Araken de Assis diz que“(..) resulta claro que a impugnação, analogamente aos embargos, e a despeito do último tramitar sempre de modo autonômo, representa uma ação de oposição à execução. Superou-se a incompatibilidade de funções e inseriu-se, consoante o modelo espanhol, um 'incidente declarativo dentro del proceso mismo de ejecución'. É flagrante, naturalmente, a posição de defesa assumida pelo executado. Daí por que, mais recentemente, pugna-se no direito germânico por uma designação mais adequada, chamando à oposição de demanda de defesa contra a execução, Vollstreckungssabwebweherklage'. Todavia, a finalidade defensiva e reativa da impugnação não lhe retira o que é essencial: o pedido de tutela jurídica do Estado, corrigindo os rumos da atividade executiva ou extinguindo a pretensão a executar. Reservar a qualidade de autêntica oposição à ação autonôma, reduzindo os embargos e, agora, a impugnação ao papel de simples contestação, obscurece o fato de que por seu intermédio o executado põe barra, susta no todo ou em parte a execução. Bem por isso é universal a idéia de que o executado veicula por ação sua reação contra execução.” (cf. Cumprimento da Sentença, p.314). No mesmo sentido Arruda Alvim (cf. "A Natureza jurídica da impugnação...", in Aspectos polêmicos da nova execução-3, p. 44-50) e José Roberto dos Santos Bedaque (cf. Algumas considerações sobre o cumprimento da sentença condenatória, in Revista do Advogado 85/73).
} 
No mais, cumpre enfatizar que a penhora tem a natureza jurídica de ato processual executivo, decorrente do princípio da responsabilidade executiva ou patrimonial, tratando-se de "vínculo de natureza processual, que faz recair um estigma sobre os bens por ela atingidos, de tal modo que não se poderá afastá-los de sua destinação, qual seja, atender à finalidade da execução". ${ }^{29}$

Como ato processual executivo, o primeiro ato propriamente executivo da execução forçada, a penhora necessariamente deve se projetar para fora do processo de modo a atingir o mundo real e iniciar o procedimento de transformação da regra jurídica, contida no título executivo, em fato. ${ }^{130}$ Nesse sentido, como ato de apreensão de bens, a penhora só se realizará se bens forem apreendidos. Assim, a existência da penhora depende da existência de bens penhoráveis no patrimônio do executado e sua eficácia depende do quão bem sucedida é tal apreensão. Por isso, é de fundamental importância estudar a base real sobre a qual penhora incide, seu objeto, os bens passíveis de serem apreendidos e sujeitos ao juízo da execução.

\subsection{O objeto da penhora}

Conforme já dito, a finalidade da execução, considerada em seu sentido mais amplo (entrega ao credor do bem da vida objeto do título executivo), é transformar a norma contida no título executivo em fato. Nesse sentido, nos casos de obrigação de pagar, por meio da execução forçada os bens do executado devem ser direcionados coercitivamente à satisfação do credor. Para tanto, o Poder Judiciário terá que tomar uma série de providências práticas para localizar, apreender, avaliar e expropriar os bens do devedor em benefício do exequente. A atividade jurisdicional neste caso incide e deve se realizar no mundo real. Tal como anota Araken de Assis ao comentar as alterações

\footnotetext{
${ }^{129}$ cf. Luiz Carlos de Azevedo (Da penhora, p. 126).

${ }^{130}$ Sobre a natureza do ato executivo, ver Araken de Assis (Manual da Execução, p. 88/91).
} 
introduzidas ao processo pela Lei n. 11.232/2005 "as regras processuais são impotentes, decerto, para alterar a realidade econômica e social". ${ }^{131} \mathrm{E}$ o mesmo Autor em assertiva já citada neste trabalho aduz em outra obra que a execução "se realiza no mundo real e, portanto, padece das respectivas contingências". ${ }^{132}$

Ora, também a penhora, como o primeiro ato propriamente executivo da execução forçada, deve ser instrumento processual compatível com a realidade econômica e social sobre a qual atua, e mais especificamente deve ser ato de apreensão aderente aos bens que se pretende apreender.

Nesse sentido, assim como a execução é dotada de "meios executivos" que variam conforme a natureza de seu objeto (obrigações de fazer, dar e pagar), ${ }^{133} \mathrm{o}$ ato de penhora na execução forçada tem mecanismos de apreensão de bens que também variam de acordo com o objeto a ser apreendido.

Na medida em que a penhora é fundamentalmente ato de apreensão de bens, é preciso conhecer as especificidades dos bens passíveis de apreensão, o objeto da penhora, para se saber quais mecanismos ou quais providências práticas devem ser tomadas para que a apreensão se concretize eficazmente. $\mathrm{O}$ operador do direito deve olhar a realidade e praticar ato processual que seja compatível ou aderente àquela, transformando-a. Parece lógico

\footnotetext{
${ }^{131}$ cf. Manual da Execução, p. 88. Nesta mesma linha, ao também tratar da Lei n. 11.232/2005 José Roberto dos Santos Bedaque observa o seguinte: “ Daí não ser nada conclusiva a afirmação de que a sentença executiva visa a dotar o ato judicial de maior dose de efetividade, o que faltaria à sentença condenatória. Por esse aspecto, todas as tutelas destinadas a eliminar a crise de adimplemento são insuficientes para, por si mesmas, alcançar esse resultado. Para tanto, é necessária alteração do mundo fático, o que depende de atos satisfativos. Não se consegue ver, portanto, como a sentença destinada a eliminar crise de adimplemento possa ser suficiente, por si só, para alcançar este objetivo. Sempre haverá necessidade de atos subseqüentes, normalmente de natureza sub-rogatória, destinados a fazer com que os efeitos da inatividade do devedor sejam afastados. Em outras palavras, somente após a condenação haverá verdadeira agressão ao patrimônio do réu. Se isso se dá no mesmo processo ou não é indiferente para efeito de classificação da sentença, bem como não influi na maior ou menor efetividade dela". (cf. "Algumas considerações sobre o cumprimento da sentença condenatória" in Revista do Advogado, 85/68). 132 cf. Cumprimento da Sentença, p. 4.

${ }^{133}$ Flávio Luiz Yarshell anota com precisão que: “A propósito dos meios executivos, é sabido que eles variam segundo a natureza do direito a ser satisfeito, isto é, do resultado a ser proporcionado ao credor, sendo predispostos de forma diversa se for o caso de entrega de quantia, ou de coisa, ou ainda a imposição e/ou efetivação de um fazer ou um não fazer. E, mesmo em cada uma dessas modalidades de obrigação, há variações ditadas por particularidades extraídas da relação material”. (cf. Tutela jurisdicional, p. 173).
} 
que apreender um valioso cavalo de raça em um haras é bem diferente de apreender dinheiro depositado em uma conta corrente bancária.

A Lei Processual admite que, a depender do objeto, a penhora se realize por diversos modos ou métodos de apreensão. Nessa linha, Couture ao tratar da penhora dizia que "essa tomada de posse admite, por sua vez, inúmeras formas: seqüestro, depósito, administração, intervenção no estabelecimento comercial do devedor, proibição de alienar, com a conseqüente inscrição no registro público, etc.. Cada uma dessas formas corresponde a uma exigência prática, e a jurisprudência é liberal em assegurar ao credor, em via preventiva uma eficaz proteção do seu direito."

Embora discordemos do posicionamento de Couture de atribuir à penhora uma natureza preventiva ou cautelar, pelos motivos já explicados, o comentário acima citado nos permite enfatizar que, a depender do objeto, pode variar o método de realização da penhora. ${ }^{135}$ E mais do que isso, o operador do direito deve bem conhecer o objeto da penhora, as características e especificidades dos bens a serem apreendidos, para utilizar o método de apreensão mais adequado para que a penhora seja eficaz.

Nessa linha, o ato de penhorar passa por bem conhecer o objeto da penhora, conhecer minimamente a realidade econômica e social para saber quais espécies de bens podem gerar penhoras mais eficazes, menos custosas, de mais fácil transformação em dinheiro e quais são os métodos de apreensão disponíveis, considerando a natureza de cada tipo de bem. Trata-se de saber localizar e escolher os bens e, após, usar os métodos mais adequados para a realização da apreensão. E na medida em que variam os modos de realização da apreensão, podem variar também alguns dos efeitos que o ato de penhora acarreta.

\footnotetext{
134 cf. Fundamentos do direito processual civil, p. 388.

135 Também esta é a posição de Enrico Tullio Liebman: “A diferente qualidade dos bens que podem ser penhorados traz consigo a conseqüência de serem diversos os meios e as formas com que se realiza a penhora. Além disso, torna-se, às vezes, difícil conhecer os bens de que compõe o patrimônio do executado e por isso é conveniente fazer em primeiro lugar uma tentativa para conseguir do próprio executado a indicação dos bens que possam ser penhorados, aproveitando para esse fim seu interesse em escolher ele mesmo entre seus haveres aqueles que serão submetidos à execução. Deriva disso tudo a variedade de formas com que o ato se pratica". (cf. Processo de Execução, p. 130).
} 
Por isso, o adequado e eficaz manejo pelo operador do direito do instituto da penhora, seja o Legislador, na prévia definição do método ou procedimento legal de apreensão, seja o Juiz, na determinação de sua realização, ou o advogado, na elaboração dos requerimentos tendentes à sua concretização, depende fortemente do conhecimento do substrato social, econômico e jurídico sobre o qual a penhora incide, ou seja, de bem conhecer o objeto da penhora.

\subsubsection{Objeto da Penhora e Tipicidade Legal}

Não há dúvida de que a Lei Processual procura estabelecer parâmetros legais para a realização do ato de penhora, que está longe de ficar ao puro arbítrio do Juiz e muito menos das partes. E é desejável que seja assim, na medida em que a penhora significa ato de força, de coerção, enfim, de invasão do patrimônio legitimamente pertencente a alguém. Não é à toa que constitui grande evolução na vida do instituto o momento em que a penhora, ainda na Roma Antiga, deixa de ser ato privado do credor dotado de uma carga quase vingativa para ser ato estatal destinado a apreender apenas os bens do devedor suficientes à satisfação do credor. No Estado de Direito atual, simplesmente não se concebe qualquer ato de força estatal sem a observância de prévia Lei que o regule, com garantias mínimas ao seu destinatário, de modo tal que a medida da força seja apenas a suficiente para atingir os fins legítimos colimados pela Lei. ${ }^{136}$

Pois bem, no caso da penhora as premissas legais básicas são as seguintes: o poder coercitivo do Estado deve ser exercido na exata medida da responsabilidade patrimonial do executado, sem que mais bens do que o necessário à satisfação do credor e sem que bens considerados por Lei inexpropriáveis ou impenhoráveis sejam indevidamente direcionados à execução.

No que se refere especificamente à tipicidade legal, ou seja, à observância do modelo legal previamente definido para que os atos executivos sejam

\footnotetext{
136 Nos termos do art. $5^{\circ}$., inciso LIV, da Constituição Federal "ninguém será privado da liberdade ou de seus bens sem o devido processo legal".
} 
considerados válidos, Flávio Luiz Yarshell nos ensina que "a maior importância do tema resulta da circunstância de que, na prática de atos executivos, dá-se a invasão da esfera patrimonial do devedor, de tal sorte que o modelo legal deverá perseguir um ponto de equilíbrio entre valores conflitantes: de um lado, a busca da satisfação do credor e da afirmação da própria autoridade estatal; de outro, a menor oneração possível do devedor." E, mais à frente, conclui: "em suma, tratando-se da tutela executiva, vigora uma regra de tipicidade no estabelecimento dos meios executivos porque a lei estabelece um modelo para tanto. Todavia, essa regra, em algumas hipóteses, é considerada relativizada, quer pela diversidade desses meios, quer pela amplitude dos poderes conferidos ao juiz para compelir o devedor ao adimplemento". 137

Não se deve, portanto, ignorar a importância da tipicidade legal na execução forçada, mas isto não quer dizer que o modelo legal seja fechado e inflexível.

Conforme é possível constatar a partir da análise histórica que fizemos do instituto da penhora, especialmente a partir do Código de Processo Civil de 1939 o Legislador passa a estabelecer determinados métodos de realização da penhora que variam conforme as especificidades ou a natureza dos bens a serem penhorados (objeto da penhora). Estes métodos nada mais são do que a fixação prévia pelo Legislador de modelos ou tipos legais que encerram um conjunto de providências práticas para que se realize a penhora de certos bens.

Há assim no Código de Processo Civil atual capítulos que regulam modos específicos de realização de penhora, quais sejam, "penhora de créditos e de outros direitos patrimoniais" (CPC, arts. 671/676) e da penhora de "empresa e outros estabelecimentos" (CPC, arts. 677/678). E há outros dispositivos legais esparsos que tratam de específicos modos de realização da penhora de "dinheiro em depósito ou aplicação financeira" em instituição bancária (CPC, art. 655-A, $\S 1^{\circ}$. e $2^{\circ}$.), da penhora de "faturamento de empresa" (CPC, art. 655-A, § $3^{\circ}$.) e da penhora de "navio ou aeronave" (CPC, art. 679). Um caso à parte é a penhora de "imóvel", que também tem um modo particular e específico de realização,

\footnotetext{
${ }^{137}$ cf. Tutela jurisdicional (p. 172/174).
} 
estabelecido em uma série de dispositivos legais dispersos no Código de Processo Civil (CPC, art. $655, \S 1^{\circ}$. e $2^{\circ}$., art. $655-\mathrm{B}$ e art. $659, \S 4^{\circ}$., $5^{\circ}$. e $6^{\circ}$.).

De outro lado, o Código de Processo Civil não estabelece métodos específicos para a realização da penhora de outros bens que não os acima nomeados, para os quais restaria o procedimento-padrão da penhora por Oficial de Justiça.

O fato é que não cabe e nem seria possível ao Legislador em razão do dinamismo da sociedade e da economia fixar de maneira exaustiva o rol de todos bens economicamente relevantes que fossem passíveis de penhora, tampouco definir previamente, para cada tido de bem, o procedimento de apreensão. Deve sim o Legislador estabelecer previamente o quadro geral do regime da penhora, ou seja, os princípios e os requisitos legais mínimos para sua realização, e procurar estabelecer expressamente os limites ao poder de penhorar.

Conforme já dito, a penhora como ato de apreensão de bens padece de contingências reais (sociais e econômicas), ou ainda, o mecanismo de apreensão deve ser aderente ao seu objeto. Assim, o fato do Código de Processo Civil deixar de estabelecer modelos ou tipos legais com procedimentos específicos para a realização da penhora de determinados bens não significa que os operadores do direito devam desconsiderar as particulares características daqueles bens na realização da penhora. Tais contingências ou particularidades do objeto devem ser consideradas pelos operadores do direito na realização da penhora, ainda que o tipo legal não as considere.

Isto quer dizer que as distintas características entre os bens passíveis de penhora, em regra, vão acarretar modos diferenciados de apreensão, ainda que na lei não haja um modelo específico de procedimento previamente definido. Ou seja, os operadores do direito, de acordo com as características do bem a ser objeto da penhora, podem desenvolver e adotar modos de apreensão distintos dos procedimentos previamente definidos em lei. Assim, por exemplo, a realização de penhora de dinheiro em instituição bancária por meio eletrônico, via o sistema BACEN-JUD, a chamada penhora on line, já era praticada e 
aceita pelos Juízes mesmo antes de sua positivação no Código de Processo Civil por intermédio da Lei n. 11.382/2006. Outro bom exemplo é a penhora de faturamento de empresa, que sequer constava expressamente na relação de bens passíveis de penhora do art. 655 do Código de Processo Civil, ou do art. 11 da Lei n. 6.830/80 (“Lei da Execução Fiscal”), e mesmo assim passou a ser paulatinamente aceita e praticada pelos Juízes e Tribunais que ainda se encarregaram de fixar por intermédio da formação da jurisprudência seus requisitos e seu procedimento, muito antes, portanto, da Lei 11.382/2006 introduzir o art. 655-A, $\S$ terceiro, no Código de Processo Civil.

Disto resulta que a penhora pode atingir bens não expressamente arrolados pelo Legislador como penhoráveis. Além disso, o método de apreensão previsto pelo Legislador pode ser adaptado na prática, conforme forem as peculiaridades do bem a ser passível de apreensão.

No que se refere aos bens que são passíveis de penhora, o art. $10 \mathrm{da}$ Lei da Execução Fiscal (Lei n. 6.830/80) traz disposição legal que define bem a questão ao afirmar que "a penhora poderá recair em qualquer bem do executado, exceto os que a lei declara absolutamente impenhoráveis". Ainda que no sistema do Código de Processo Civil não haja uma literal disposição neste sentido, o princípio é o mesmo. A interpretação conjugada dos artigos 591 e 648 do Código de Processo Civil nos conduz à conclusão de que "o devedor responde ... com todos os seus bens presentes e futuros" (art. 591), salvo "os bens que a lei considera impenhoráveis ou inalienáveis" (art. 648). Trata-se de decorrência lógica do princípio da responsabilidade patrimonial e de suas limitações, conforme tivemos oportunidade de expor acima. Por isso, são penhoráveis todos os bens constantes do patrimônio do executado, ainda que não expressamente nominados no rol do art. 655 do Código de Processo Civil, exceto aqueles declarados por lei como impenhoráveis. ${ }^{138}$

Quanto ao procedimento de realização da penhora, entendemos que, fundamentalmente, (a) deve ser determinada e controlada pelo Juiz, com o apoio do Oficial de

\footnotetext{
${ }^{138}$ De todo modo, é certo que a amplitude de certas classes do rol do art. 655 permita nele incluir uma grande variedade de bens em circulação na nossa economia.
} 
Justiça, sempre que necessário, ${ }^{139}$ (b) deve incidir sobre bens suficientes à satisfação do crédito, e neste limite deve ser feita (CPC, art. 659), e (c) implica na apreensão e, nos casos em que isto for possível, depósito dos bens, a ser formalizada em um auto de penhora (CPC, art. 664 e 665$)$.

Assim, o sistema processual confere uma razoável flexibilidade na operacionalização da penhora ao optar por descrever previamente alguns métodos específicos de apreensão para alguns bens, e ao estabelecer um tipo legal padrão de apreensão suficientemente genérico para todos os outros bens, de modo a permitir certa flexibilidade na atuação dos operadores do direito na busca de uma penhora eficaz.

\subsubsection{Objeto da penhora e método de Apreensão}

Como vimos, a penhora é ato processual que depende das contingências reais e concretas do seu objeto, as peculiaridades e características do bem a ser apreendido, enfim, a maneira pela qual o bem circula na economia e existe no mundo real. Tais contingências determinarão o método ou o procedimento ou a forma de apreensão do bem.

O método de apreensão engloba uma série de providências práticas para que a apreensão se efetive e para que o bem seja conservado ou protegido até o momento em que ocorra a expropriação forçada.

Estas providências devem interferir na afetação jurídica do bem aos fins de interesse do executado, impedindo-o de exercer plenamente os seus poderes em relação ao bem, o qual passa a ficar afetado aos fins da execução. ${ }^{140}$ Trata-se de providências que

\footnotetext{
${ }^{139} \mathrm{O}$ art. 577 do Código de Processo Civil estabelece que, não dispondo a lei de modo diverso, o juiz determinará os atos executivos e os oficiais de justiça os cumprirão. No nosso entendimento, contudo, nada impede que a penhora seja cumprida sem a participação do Oficial de Justiça, desde que haja método mais eficiente para a realização da apreensão, passível de determinação e controle pelo próprio Juiz. Foi o caso da penhora on line, agora positivada em nosso Código de Processo Civil.

${ }^{140}$ Trata-se de afirmação baseada no conceito de penhora constante da obra do Professor português José Lebre de Freitas, segundo o qual: "A satisfação do direito do exeqüente é conseguida no processo de execução, mediante a transmissão de direitos do executado, seguida, no caso de ser feita para terceiro, do pagamento da dívida
} 
devem retirar do executado o poder de dispor eficazmente do bem penhorado em prejuízo do juízo executivo. ${ }^{141}$

Tais providências variam em função das características do bem a ser submetido à penhora. Assim, por exemplo, no caso de penhora de uma obra de arte, a localização do bem pode partir de diligências do oficial de justiça na casa do executado ou de informações previamente detidas pelo exeqüente, sua apreensão dependerá do oficial de justiça ver a obra no local em que ela esteja para descrevê-la no auto de penhora e após apreendê-la e fazer o depósito. Se o próprio executado for nomeado depositário, com sua intimação, e sua não objeção ao encargo, a penhora se aperfeiçoa, ficando a obra de arte no mesmo local em que ela foi encontrada. Se o depositário for terceiro, o oficial de justiça deverá providenciar transporte adequado à obra de arte, possivelmente sob as expensas do Exeqüente, retirando-lhe do local em que se encontrava para colocá-la no lugar indicado pelo depositário. Pegue-se como outro exemplo a penhora de dinheiro. O dinheiro é a moeda de troca da economia que invariavelmente assume forma escritural, ou seja, intangível, por força de registros bancários. Sua liquidez e facilidade de circulação são máximas. A forma mais segura de afetá-lo ao Juízo da execução, inclusive protegendo-o dos efeitos da perda de poder aquisitivo da moeda, é depositá-lo em instituição bancária (CPC, art. 666, I), até porque, caso a execução não seja obstada por nenhuma outra medida judicial proposta pelo executado, o dinheiro pode e deve ser imediatamente vertido ao exeqüente, resolvendo a execução. Não há método de eficácia equivalente. Além do que, trata-se de método de apreensão de baixo custo e de fácil concretização, especialmente a partir do desenvolvimento e adoção do sistema BACEN-JUD que permite o bloqueio eletrônico do dinheiro em conta corrente bancária do executado e sua transferência imediata para uma conta vinculada ao Juízo da execução (CPC, art. 655-A, caput).

exeqüenda. Mas, para que essa transmissão se realize, há que proceder previamente à apreensão dos bens que constituem o objecto desses edireitos, ao mesmo tempo paralisando ou suspendendo, na previsão dos actos executivos subsequentes, afectação jurídica desses bens à realização de fins do executado, que fica conseqüentemente impedido de exercer plenamente os poderes que integram os direitos de que sobre eles é titular, e organizando sua afectação específica à realização dos fins da execução". (cf. José Lebre de Freitas, $A$ acção executiva, p. 205).

${ }^{141}$ cf. Pontes de Miranda (Comentários ao Código de Processo Civil, XIII, p. 219/220). 
Em razão do grande número de bens passíveis de penhora e das especificidades de cada um desses bens, não é fácil fazer uma classificação funcional dos métodos ou formas de penhora, de acordo com a natureza daqueles bens. A lei portuguesa trata da penhora de bens imóveis, penhora de bens móveis e penhora de direitos; a lei italiana da penhora de móveis junto ao devedor, penhora de móveis junto de terceiros, penhora de imóveis, penhora de bens indivisos e penhora contra o terceiro proprietário; e a lei alemã da penhora de bens imóveis e penhora de móveis, esta subdividida em penhora de coisas corpóreas e penhora de créditos e outros direitos patrimoniais. ${ }^{142}$

O nosso Código de Processo Civil preferiu distinguir em Seções específicas apenas a "penhora de créditos e de outros direitos patrimoniais" (CPC, arts. 671/676) e a "penhora de empresa e outros estabelecimentos" (CPC, arts. 677/678), parecendo deixar a todos os outros tipos de bens o método padrão descrito na Seção "Da Penhora e do Depósito" (CPC, arts. 659/670). Mas não se trata de classificação sistemática, pois, como já dissemos, a penhora de "imóvel” tem um procedimento específico regulado em dispositivos esparsos. Além disso, a penhora de "dinheiro em depósito ou aplicação financeira" em instituição bancária (CPC, art. 655-A, $\S 1^{\circ}$. e $2^{\circ}$.) e a penhora de "faturamento de empresa" (CPC, art. 655-A, $\S 3^{\circ}$.), positivadas pela Lei n. 11.382/2006, teriam ficado muito mais apropriadamente dispostas, a primeira, na seção da penhora de "créditos e direitos" e, a segunda, na seção dedicada à penhora de "empresas e outros estabelecimentos". De todo modo, embora o assunto pudesse estar mais bem organizado no Código de Processo Civil, não é tarefa precípua do Legislador fazer classificações e, como já vimos no capítulo precedente, não deve se esperar que a lei disponha sobre todos os métodos ou formas de penhora existentes.

Para simplificar e servir como apoio de nossa análise, trataremos de duas grandes classes de métodos de penhora, a penhora de bens corpóreos ou materiais e a penhora de bens incorpóreos ou imateriais.

\footnotetext{
$\overline{142}$ cf. José Lebre de Freitas (A acção executiva, p. 247).
} 


\subsubsection{A penhora de bens corpóreos}

$\mathrm{Na}$ penhora de bens corpóreos, há apreensão física do bem e depósito em mãos do depositário, a pessoa responsável por guardar e conservar o bem até o momento da expropriação. O procedimento de apreensão, em regra, será realizado por meio do Oficial de Justiça, nos termos dos artigos 659 a 666 do Código de Processo Civil.

O depósito é providência essencial para que a penhora de bens corpóreos se concretize, sendo indissociável do ato de apreensão. Aplica-se aqui em sua inteireza a disposição do art. 664, caput, do Código de Processo Civil (CPC, art. 664, caput). ${ }^{143} \mathrm{E}$ tem que ser assim, pois apreendido o bem este deve ser imediatamente e necessariamente guardada com alguém para que se conserve intacto até o momento da expropriação forçada.

A penhora de bens corpóreos pode se dar por apreensão real ${ }^{144}$ ou ficta. Será ficta nos casos em que o bem continua em poder do executado. Nestes casos, é o próprio Executado que figura como depositário do bem. Será real nos casos em que o bem é retirado do poder do Executado. Nestes casos, o depositário do bem será sempre terceiro.

$\mathrm{Na}$ sua literalidade, a Lei Processual confere ao Exeqüente a faculdade de escolher se a apreensão será ficta ou real, pois, nos termos do art. 666, § primeiro, do Código de Processo Civil, dependerá de sua expressa anuência figurar o Executado como depositário dos bens apreendidos, a não ser nos casos em que os bens forem de difícil remoção. À primeira vista parece então que ser a apreensão ficta ou real dependerá fundamentalmente da vontade do Exeqüente.

A verdade é que a penhora nasce como ato de efetivo desapossamento do bem das mãos do executado, tal como dispunha as Ordenações Filipinas.

\footnotetext{
${ }^{143}$ Segundo Araken de Assis, o referido dispositivo legal "estabelece correlação obrigatória entre a apreensão da coisa penhorada e o desapossamento do executado, cujo instrumento reponta no depósito". (cf. Manual da execução, p. 622).

${ }^{144}$ Também chamada de filhada, "ato de filhar, de apreender usando a força". (cf. Dicionário Houaiss da língua portuguesa, p. 1342).
} 
Eis aí em todo o seu alcance o sentido do ato de "apreensão", o termo por nós utilizado para designar aquilo que essencialmente define a "penhora". Ocorre que ao longo do tempo, começou-se a mitigar a necessidade de em qualquer caso realizar-se a apreensão efetiva e real do bem, tirando-o do poder do executado, para o aperfeiçoamento da penhora. Vimos também na "análise histórica" do instituto que desde pelo menos o Regulamento n. 737 passou-se a permitir que o próprio executado assumisse o encargo de depositário do bem penhorado, desde que com isso conviesse o exeqüente. E ainda sob a égide do Regulamento n. 737, a eventual contrariedade do exeqüente a figurar o executado como depositário do bem já deveria ser justificada e fundamentada para ser aceita pelo Juiz.

O fato é que, a partir de uma visão histórica e sistemática do regime da penhora, verifica-se que o princípio que vige há algum tempo em nosso sistema é nomear o executado como depositário do bem, sempre que esta providência for capaz de garantir com segurança a afetação do bem apreendido ao Juízo da execução até o momento de sua expropriação. Nesse sentido, a função processual da penhora é alcançada de maneira mais eficiente, com menos custos à estrutura judiciária e ao exeqüente, como também com menos gravosidade ao executado (CPC, art. 620).

E tal como vimos insistindo neste trabalho, será menos a vontade do exeqüente ou do executado e mais a natureza e as características do bem a ser apreendido que serão determinantes para a escolha do método mais eficiente de realização da apreensão. Há bens cuja apreensão real não traria nenhuma vantagem em relação ao método de apreensão ficta, no sentido de se obter uma mais segura afetação do bem ao Juízo da execução. É o caso dos imóveis, por exemplo, cuja impossibilidade de remoção e cujo registro da penhora no Cartório de Imóveis com presunção absoluta de conhecimento de terceiros (CPC, 659, par. $4^{\mathrm{o}}$.) não dão margem à prática de atos fraudulentos de perdimento do bem apreendido. Há ainda a vantagem de ser método de apreensão pouco custoso e que garante, sem maiores percalços, a manutenção da destinação econômica e social do bem até o momento da expropriação. ${ }^{145}$ Por

\footnotetext{
${ }^{145}$ Como observa Araken de Assis "tolera-se, ..., a manutenção da posse imediata do imóvel, não porque haja 'comodismo e sentimentalismo', e sim pela necessidade de respeitar a posse de terceiro (v.g., locatário) e mitigar a gravosidade do despejo imediato do executado, intercalando-se, nessas contingências, a posse mediata do
} 
isso, o Código de Processo Civil no seu art. 659, $\S 5^{\circ}$., determina que será o executado o depositário da penhora de bem imóvel. De outro lado, há bens cuja apreensão real é a única forma de se garantir a afetação ao Juízo da execução. Pode ser usado como exemplo o dinheiro na forma de papel-moeda (bem corpóreo) ou bens móveis de fácil remoção, como jóias ou pedras preciosas. Há ainda os bens para os quais não se despontam vantagens tão claras de uma ou outra forma de apreensão, real ou ficta. Nestes casos, normalmente se opõe a maior segurança da apreensão real e o menor custo da apreensão ficta. Pegue-se novamente o exemplo da obra de arte. A apreensão real trará ao exeqüente os custos de manutenção do depósito em condições que proporcionem a adequada preservação do bem em mãos de terceiro (CPC, 149). A apreensão ficta não terá custos adicionais, na medida em que o próprio executado figurará como depositário, mas embute o risco do executado se ver tentado a praticar atos fraudulentos a fim de retirar o bem da órbita judicial, ainda que premido por pesadas penalidades cíveis e criminais (CPC, 666, $\S 3^{\circ}$. - prisão civil - e $\mathrm{CP}$, art. 179). Nestes casos em que não se afigura uma clara vantagem na comparação entre os dois métodos de apreensão, outras circunstâncias específicas do caso concreto, tal como a idoneidade e reputação do executado, e a vontade do exeqüente, incluindo sua disposição em arcar com os custos do depositário, terão um peso importante na determinação do método de apreensão pelo Juiz, além das características do bem a ser apreendido.

\subsubsection{A penhora de bens incorpóreos}

$\mathrm{Na}$ penhora de bens incorpóreos, a apreensão judicial se dá por ordens judiciais ao executado e a terceiros para que sejam praticados atos que propiciem a afetação do bem ao Juízo da execução e sua conservação até o momento da expropriação.

O sistema-base para a penhora de bens incorpóreos é aquele descrito nos artigos 671 a 676 do Código de Processo Civil, que trata da penhora de "créditos e outros direitos patrimoniais", cuja disciplina é específica, “[...] em face da natureza do objeto sobre que se dá, nesses casos, a apreensão judicial". ${ }^{146}$ A penhora de empresa e

depositário. Por tal motivo, tratando-se de imóvel, o depósito se realiza nas mãos do executado". (cf. Manual da Execução, p. 621).

${ }^{146}$ Celso Neves (Comentários ao Código de Processo Civil, v. 7, p. 83). 
estabelecimento empresarial, do art. 677 a 678 do Código de Processo Civil, também é modalidade de penhora de bem incorpóreo, de regime particular, por envolver administração de universalidade, sobre o qual trataremos detalhadamente ao abordarmos estas específicas modalidades de penhora.

O procedimento de penhora de crédito, cujo esboço é o do Código de Processo Civil de 1939, baseia-se em uma premissa fundamental, qual seja, a imaterialidade do crédito não possibilita a apreensão física do bem e o ato de afetação jurídica do bem à execução necessariamente implicará no envolvimento de um terceiro, alheio à execução (debitor debitoris). ${ }^{147}$

O procedimento da penhora de crédito, como veremos mais adiante, será aplicável a outros bens incorpóreos, com algumas adaptações, em razão da natureza específica de cada tipo de bem. Por isso, é importante analisarmos o procedimento de penhora de crédito como referência ao método de apreensão de outros bens incorpóreos. ${ }^{148} 149$

A penhora de crédito passa pelas providências determinadas nos incisos I e II do art. 671 do Código de Processo Civil, ou seja, pela intimação judicial (a) ao terceiro devedor ou devedor do executado (debitor debitoris) para que não pague ao seu executado e ao (b) executado para que não pratique ato de disposição do crédito.

Na essência, a penhora de crédito se dá por uma ordem judicial que visa tornar indisponível o direito do executado, que não poderá receber o dinheiro na data do

\footnotetext{
${ }^{147}$ Conforme Araken de Assis "a penhora de crédito abrange o dinheiro do executado em mãos de terceiro, quaisquer créditos que não permitam apreensão por sua imaterialidade, presentes ou futuros, títulos diversos (art. 672, caput), direitos potestativos, inclusive já litigiosos (art. 674)." (Manual da Execução, p. 640). Na mesma linha, Bruno Garcia Redondo e Mário Vitor Suarez Lojo, "o objeto da penhora de crédito do executado por terceiro compreende o dinheiro do executado que se encontre em mãos de terceiro, seja qual for a fonte jurígena deste crédito - créditos imateriais (que não permitem apreensão em razão da sua imateralidade), créditos presentes, futuros ou litigiosos. Os créditos litigiosos ensejam a chamada penhora no rosto dos autos". (Penhora, p. 193).

${ }^{148}$ Segundo Celso Neves "tenham essas relações as características de débito ou crédito ou assinalem quaisquer outros direitos patrimoniais, sobre elas admite o Código a incidência da penhora, estabelecendo, para isso, uma discipina específica, em verdade necessária, em face da natureza do objeto sobre que se dá, nesses casos, a apreensão judicial”. (Comentários ao Código de Processo Civil, v. 7, p. 83).

${ }^{149}$ Ver neste sentido também Enrico Tulio Liebman (Processo de execução, p. 135) e José Frederico Marques (Instituições de direito processual civil, vol. V, p. 199).
} 
vencimento da dívida, tampouco poderá ceder seu crédito a terceiros. Assim, nesta modalidade de penhora há emissão de ordens a terceiro e ao executado, de modo a impedir este último de exercer seu poder de dispor do bem, seja transferindo o crédito a outrem, seja recebendo o dinheiro àquele pertinente.

A Doutrina, contudo, entende não haver propriamente indisponibilidade do crédito, mas ineficácia em relação à execução de qualquer ato de disposição do crédito feito pelo executado. Esta é a opinião de Araken de Assis, segundo o qual a "intimação do executado para que 'não pratique atos de disposição do crédito' (art. 671, II) [...] representa bis in idem, porquanto os atos do executado já despontam ineficazes desde a propositura da execução". ${ }^{150}$ E também Celso Neves: "isso mostra que a penhora de créditos tal como a penhora de bens - não implica indisponibilidade, no plano material, mas torna ineficazes, no processo, os atos de disposição. Por isso, se o devedor do executado, na hipótese já formulada, a ele paga o valor da dívida, tal pagamento é irrelevante no processo executório, onde subsiste a responsabilidade decorrente da penhora, em sua plena eficácia". ${ }^{151}$

Quer dizer, segundo a Doutrina, a partir do momento que o devedor do executado ou o debitor debitoris é intimado a não pagar o "crédito" ao executado, ainda que o executado venha dispor de seu "crédito" a terceiro ou mesmo receba o pagamento do debitor debitoris, estes atos são válidos no plano do direito material, mas são totalmente ineficazes em relação ao processo, sendo certo que o debitor debitoris continuará a ter o dever

\footnotetext{
${ }^{150}$ cf. Araken de Assis (Manual da execução, p. 641).

151 cf. Comentários ao Código de Processo Civil, v. 7, p. 84.
} 
processual de depositar no Juízo da execução o dinheiro equivalente ao crédito penhorado. ${ }^{152}$ 153

Nos parece, entretanto, que a penhora de "crédito" só permite a afetação segura do bem ao Juízo da execução tornando-os materialmente indisponíveis ao executado. É certo que a mera emissão de ordens pelo Juiz ao executado e ao debitor debitoris não é garantia de que a indisponibilidade determinada pelo Juiz será observada pelo executado. Nesse contexto, reconhecer-se a ineficácia de eventual ato de disposição perante o Juízo da execução já é o suficiente para vincular o debitor debitoris a fazer o depósito do dinheiro equivalente ao "crédito" em Juízo e também para preservar a integridade das relações de direito material decorrentes do ato de disposição do "crédito" pelo executado.

Mas sempre que o Legislador tem os meios necessários para tornar indisponível o "crédito" pelo executado, obstando qualquer transferência do bem a terceiros após a concretização da penhora, ele o fará, pois esta é a única maneira segura de vincular este tipo de bem, e outros tipos de bem incorpóreo, ao Juízo da execução, pois a mera ineficácia relativa como conseqüência da penhora não é medida suficiente para ter o bem incorpóreo, que circula com grande rapidez e facilidade na economia, efetivamente vinculado ao Juízo da execução. Nestes casos, em regra, o impedimento à prática pelo executado de quaisquer atos

\footnotetext{
${ }^{152}$ Este é o entendimento, por exemplo, de Celso Neves, ao dizer que o debitor debitoris: “ estará sujeito à cobrança executiva da dívida e às constrições daí decorrentes, como devedor do executado, mesmo que a este tenha pago a dívida, porque a eficácia processual da penhora fixa essa sua responsabilidade, que só cessa com a satisfação do exequente ou com a renúncia deste aos direitos que da execução lhe decorrem. É verdade que o parágrafo $2^{\circ}$. diz que o 'terceiro só se exonerará da obrigação depositando em Juízo a importância da dívida'. Entenda-se: não da obrigação de direito material, mas do dever processual, resultante da penhora, de depositar, em Juízo, o valor de seu débito, pena de sujeitar-se a fazê-lo, coativamente, pelos meios que disporia o seu credor, e que, pela penhora, cabem, também, à disponibilidade direta ou indireta do Juízo executório. Direta, quando ele mesmo determina a execução contra o devedor do executado (artigo 673); indiretamente, quando, em hasta pública, transfere ao arrematante o direito do crédito penhorado (parágrafo primeiro do art. 673).”(cf. Comentários ao Código de Processo Civil, v. 7, p. 87).

${ }^{153}$ Também Pontes de Miranda: "O princípio geral consiste em que, ultimada qualquer medida constritiva, qualquer transferência da propriedade, gravame, ou cessão, é ineficaz em relação ao terceiro que a obteve. A ineficácia é relativa. É essa ineficácia a que se referem, aqui e ali, broncamente, os legisladores, dizendo que a transferência, o gravame ou a cessão, após as medidas constritivas, ou algum outro acontecimento que restrinja a eficácia. [...] Assim, o Código Civil, art. 1077 há de ser lido como se lá estivesse dito: 'O crédito, uma vez judicialmente constrito, não pode ser eficazmente transferido pelo credor que tiver conhecimento da constrição; mas o devedor que o pagar, não tendo notificação da medida constritiva, fica exonerado subsistindo somente contra o credor os direitos de terceiro". (cf. Comentários ao Código de Processo Civil, XIII, p. 258/259). Note-se que o art. 1077 mencionado por Pontes de Miranda é o equivalente ao art. 298 do Código Civil atual.
} 
de disposição do bem a terceiros será a medida de fato eficaz para impedir o exercício pelo executado de seu poder de dispor em prejuízo ao Juízo executivo. Só assim, de fato, retira-se o poder do executado dispor eficazmente do bem perante o Juízo da execução, não sendo suficiente o efeito da ineficácia relativa.

Isto resulta evidente na penhora de "aplicação em instituição financeira" que em muitos casos nada mais é do que um direito de crédito do executado contra uma instituição financeira (debitor debitoris). ${ }^{154}$ Aqui, retirar o poder de disposição do executado sobre o dinheiro depositado em conta é a única maneira de afetar o bem ao Juízo da execução, sendo evidentemente insuficiente pensar a questão apenas em termos de ineficácia relativa de eventual ato de disposição. O cerne da eficácia deste tipo de penhora é a indisponibilidade do "crédito", operada pelo bloqueio judicial do sistema BACEN-JUD, nos termos do art. 655-A do Código de Processo Civil. Da mesma forma ocorre com o título de crédito em sua configuração clássica, ou seja, do "crédito" corporificado em documento escrito.

Nesse sentido, sempre que o "crédito" for corporificado em título de crédito, determina o art. 672 do Código de Processo Civil que haja apreensão física do documento, com depósito em instituição financeira (CPC, art. 666, I), funcionando as providências dos incisos I e II do art. 671 do Código de Processo Civil como uma "prépenhora". 155

O objetivo da apreensão física do documento é justamente (a) garantir que o debitor debitoris não pague o valor consignado no título ao executado-credor e (b) impedir que o credor transfira o "crédito" corporificado no título a terceiros. Por força do regime jurídico dos títulos de crédito, tal providência concretamente impede que o executadocredor exerça seu poder de disponibilidade sobre o título de crédito ou do direito nele inscrito.

\footnotetext{
${ }^{154}$ Conforme Araken de Assis "concebe-se a penhora de dinheiro investido a prazo fixo em instituição financeira, acompanhado do pagamento periódico de juros ou, ainda, de direitos a certas rendas ou prestações periódicas (p. ex, locação). Nessas hipóteses, atraentes ao credor porque as rendas oferecem dinheiro (v.g., no caso de execução de alimentos, o art. 17 da Lei 5.478/1968), há penhora de crédito do executado”. (cf. Manual da Execução, p. $650)$.

${ }^{155}$ Conforme anota Araken de Assis (Manual da execução, p. 641).
} 
Isto porque sem o título em mãos o executado não poderá transferi-lo a terceiros, mediante endosso, ${ }^{156}$ tampouco receber do devedor o pagamento do "crédito", o que pressupõe a entrega do título ao devedor. ${ }^{157}$ Há assim, neste caso, evidente e concreta indisponibilidade do poder do executado sobre o bem em sua esfera material, pois há meios efetivos para que isso ocorra.

É, assim, em regra, pela obstrução de atos de transferência e circulação do bem a terceiros que se faz a penhora de "crédito" e também de outros bens incorpóreos, pois só assim se garantirá a afetação segura do bem ao Juízo da execução. Por isso, faz todo sentido o disposto no artigo 671, inciso II, do Código de Processo Civil, embora nem sempre terá o Juiz o instrumento adequado para de maneira absoluta impedir que o executado aja no sentido de dispor de seu "crédito" ou do bem incorpóreo a terceiros.

\subsection{Efeitos da penhora}

Araken de Assis e Barbosa Moreira classificam os efeitos da penhora em (a) processuais e (b) materiais. ${ }^{158}$ Os primeiros se referem preponderantemente à órbita do Direito Processual e os segundos ao Direito Material.

Realizada a penhora, aquele ato passa a produzir os efeitos previstos na Lei Processual. Tais efeitos, chamados processuais, ocorrem qualquer que seja o objeto da

\footnotetext{
${ }^{156}$ Como ensina Fran Martins, ao tratar da "letra de câmbio", regulada por regime-base aplicável aos títulos de crédito em geral: "Para que a letra de câmbio possa facilmente ser transferida e se opere, assim, a circulação dos direitos de crédito nela incorporados, emprega-se um meio fácil, próprio dos títulos de crédito: o endosso. Consiste esse na simples assinatura do proprietário da letra, no verso ou anverso da mesma, antecedida ou não de uma declaração indicando a pessoa a quem a soma deve ser paga. Com essa assinatura a pessoa que endossa o título, chamada endossante, transfere a outrem, chamado endossatário, a propriedade da letra (Lei Uniforme, art. 14)" (Títulos de Crédito, vol I, p. 149).

${ }^{157}$ Segundo Fran Martins, também sobre a letra de câmbio, conforme explicado na nota acima: "Ao receber a importância mencionada na letra, sendo assim, satisfeita a obrigação constante da mesma, o portador deve entregar o título, com quitação àquele que efetuou o pagamento (Lei Uniforme, art. 39, $1^{\mathrm{a}}$. al.). Não compete assim, ao portador dar outra qualquer quitação, em documento separado, nem a isso pode ser compelido. Sendo a letra um documento que vale por si só, o que significa um documento completo, quitada devidamente atesta, o recebimento, pelo portador, da importância nela mencionada". (Títulos de crédito, vol I, p. 259).

158 cf. Araken de Assis, Manual da execução, p. 592-593 e José Carlos Barbosa Moreira, O Novo Processo Civil Brasileiro, p. 243.
} 
penhora e o método de apreensão: (a) há uma individualização do bem que vai suportar a responsabilidade executiva; (b) há a constituição de uma garantia do juízo da execução, que deve ser conservada até a futura expropriação; (c) há a constituição de um direito de preferência do Exeqüente em relação a outros credores quirografários que venham a penhorar o mesmo bem (CPC, art. 612) e (d) há o desencadeamento da técnica expropriativa. ${ }^{159}$

A penhora produz, ainda, tal como vimos insistindo no curso deste trabalho, efeitos que se projetam para fora do processo. Lembre-se uma vez mais que a penhora é ato processual tipicamente executivo e que, portanto, incide sobre o mundo real. Parece lógico que sua função de apreender e conservar determinado bem com vistas à futura satisfação do exequiente traz transformações ao mundo real, sejam físicas, sejam jurídicas. ${ }^{160}$

No passado mais remoto de aplicação do instituto, segundo o regime das Ordenações Filipinas, por exemplo, estas transformações do mundo real eram evidentes, na medida em que toda penhora significava apreensão real de bens. Assim, ainda que a penhora não significasse a expropriação do bem do executado, com a apreensão o executado era desapossado do bem e sofria claras limitações ao pleno exercício de seu direito de propriedade. Com o tempo, no Brasil a partir do Regulamento n. 737, a legislação passou a aceitar que o devedor permanecesse na guarda dos bens penhorados, que eram geralmente corpóreos (apreensão ficta), situação que foi se tornando cada vez mais comum e tornando menos evidentes os efeitos extraprocessuais da penhora. Este contexto pode ter contribuído para que processualistas como Liebman e José Frederico Marques, embora definissem com precisão os aspectos processuais da penhora, relegassem a um plano quase inexistente seus efeitos materiais. ${ }^{161}{ }^{162}$ Possivelmente, tal entendimento estava calcado em uma visão do

\footnotetext{
${ }^{159}$ Nesta classificação nos baseamos, com alguns temperamentos, nas idéias de Araken de Assis (cf. Manual da execução, p. 596-598) e José Carlos Barbosa Moreira (cf. O novo processo civil brasileiro, p. 243).

160 Nos termos da lição de Araken de Assis: “A penhora produz efeitos no plano subjacente ao processo, atestando a necessidade de preparar o desenvolvimento e a ultimação da técnica expropriativa, em geral culminada pela transferência forçada do bem a terceiro. O êxito desta atividade sub-rogatória se funda no controle judiciário sobre a res pignorata, sem o qual o adquirente dificilmente obterá o domínio e a posse do bem”. (cf. Manual da execução, p. 593).

${ }^{161}$ Segundo Liebman " a penhora não afeta de modo absoluto as relações de direito material existentes, não produz nem perda nem enfraquecimento da faculdade do executado de dispor de seus bens, nem qualquer espécie de direito do exeqüente sobre os bens penhorados. O efeito da penhora é, pois, meramente processual e consiste em imprimir a responsabilidade na coisa apreendida de forma tal que a coisa continua sujeita à execução, quaisquer que sejam os atos realizados pelo executado a seu respeito: em outras palavras a alienação total ou
} 
Direito Processual segregada do Direito Material. Hoje, contudo, se admite com tranqüilidade a interdependência do Direito Processual e do Direito Material, um influenciando o outro. ${ }^{163}$ Por outro lado, há uma utilização crescente de métodos de apreensão, especialmente dos cada vez mais comuns bens imateriais, que implicam na obstrução do poder de disposição do executado sobre o bem, especialmente o dinheiro em Banco via o sistema BACEN-JUD, situação em que o executado fica completamente desprovido do bem de sua titularidade e os efeitos extraprocessuais da penhora são inequívocos. Nesse cenário, é impossível não reconhecer que a penhora tem importantes efeitos materiais na esfera jurídica do executado.

\subsubsection{Efeitos sobre o poder de disposição}

O primeiro efeito material da penhora é acarretar a ineficácia de eventuais atos de disposição do bem praticados pelo executado perante o juízo da execução. Quer dizer, eventual ato de alienação ou disposição do bem a terceiro será válido entre as partes, mas não produzirá quaisquer efeitos perante o Juízo da execução ao qual a penhora está vinculada. Tal alienação então terá seus efeitos de Direito Material limitados pela marca de Direito Processual que a penhora impõe sobre o bem, vinculando-o definitivamente ao destino da execução. Sendo assim, ainda que o bem penhorado tenha sido adquirido por terceira

\footnotetext{
parcial do bem (ou a constituição de direito de garantia sobre o mesmo) não pode ser oposta ao exeqüente e não pode impedir o prosseguimento da execução, permanecendo a sujeição daquele bem ao poder executório do órgão público, qualquer que seja o direito adquirido por terceiro sobre o mesmo. A penhora impõe, pois, sobre a coisa um vínculo de caráter processual que, sem afetar os direitos do executado, sujeita a mesma ao poder sancionatório do Estado para servir à satisfação do exeqüente; vínculo que permanece invariado quaisquer que sejam as modificações que possam ocorrer na condição jurídica da coisa. O direito do executado sobre ela coexiste, intacto em sua essência, com o vínculo processual que o ato de penhora impôs sobre a mesma; qualquer forma de exercício daquele direito é permitido, em quanto praticamente possível, mas não altera este vínculo. Se a execução por qualquer motivo for desfeita, o terceiro que adquiriu eventualmente algum direito sobre os bens penhorados poderá pretender satisfazê-los; mas, enquanto a execução continuar, nada poderá fazer que prejudique o exeqüente ou outros credores concorrentes". (cf. Processo de execução, p. 127).

162 cf. José Frederico Marques, Instituições de direito processual civil, V, p. 183.

163 José Roberto dos Santos Bedaque, por exemplo, demonstra "a íntima relação dos institutos processuais com a situação de direito material trazida à apreciação do órgão jurisdicional. Este nexo intenso pode ser verificado pela própria concepção de jurisdição, ação, defesa e processo. Conforme se verá oportunamente, todas as definições e conceitos levam em conta elementos inerentes à relação de direito substancial. Também vários dos temas ligados a cada um desses institutos fundamentais têm grande nexo com a situação material. $\mathrm{Na}$ verdade, o direito substancial constitui elemento integrante de todo o direito processual, pois é parâmetro para o exercício da ação e da jurisdição". (cf. Direito e Processo, p. 65).
} 
pessoa, a execução forçada prosseguirá normalmente até a expropriação do bem em favor do exeqüente. $^{164}$

Note-se que este efeito da penhora não importa em perquirir a ocorrência dos requisitos caracterizadores da "fraude à execução" que torna ineficaz qualquer ato de alienação ou oneração de bens feito pelo executado "quando, ao tempo da alienação ou oneração, corria contra o devedor demanda capaz de reduzi-lo à insolvência" (CPC, art. 593, II). Isto porque, na lição de Yussef Said Cahali, no caso da alienação do bem penhorado "a) o ato de disposição praticado pelo devedor considera-se ineficaz quanto ao exeqüente, no sentido de permitir a excussão do próprio bem, ainda que em mãos de terceiros, como se o mesmo não tivesse saído do patrimônio do executado; e b) prescinde-se da averiguação do requisito da insolvência do devedor-executado, referida no art. 593, II, do CPC, a que possa ter sido reduzido o patrimônio do demandado em razão da alienação". ${ }^{165} 166167$

Nesse sentido, a ineficácia da alienação decorre do ato de penhora em si, pouco importando se o executado tem outros bens para responder à execução. $\mathrm{O}$ fato é que a penhora vincula o bem ao destino da execução, esteja o bem no patrimônio do executado ou não, sendo por isso mesmo completamente desnecessário que o Juiz da execução venha a proferir decisão de ineficácia de eventual alienação do bem penhorado. ${ }^{168}$

\footnotetext{
164 cf. Araken de Assis, Manual da execução, p. 593/594 e Barbosa Moreira, O novo processo civil brasileiro, p. 243.

165 cf. Fraude contra credores, p. 587.

${ }^{166}$ Fixado este entendimento, neste ponto, ousamos discordar da posição de Araken de Assis, segundo o qual a ineficácia do ato de alienação do bem penhorado só reforça, via tutela penal, ineficácia anterior, pertinente à impossibilidade de alienação de bens do devedor a partir de sua citação ("fraude à execução"). (cf. Manual da execução, p. 594). Isto porque para que a alienação anterior à penhora seja considerada ineficaz é preciso comprovar a ocorrência dos atos que caracterizam a prática de fraude à execução, mormente a comprovação do estado de insolvência do Executado, ou seja, que ele não tem outros bens passíveis de suportar a execução. Tratase de situação diferente da alienação do bem penhorado, essencialmente ineficaz, sem maiores considerações adicionais.

${ }^{167}$ Neste sentido, conferir julgado do extinto Primeiro Tribunal de Alçada Civil de São Paulo (RT 416/207).

${ }^{168}$ Segundo Youssef Said Cahali "a alienação do bem penhorado (ou arrestado) não se insere na provisão do art. 593, II, do CPC, nem tipifica modalidade de fraude de execução: os bens constritados ficam submetidos ao poder jurisdicional do Estado; a apreensão da coisa é ato formal e solene, de tal modo que se considera ineficaz perante o credor qualquer ato de disposição da mesma a que se proponha o devedor”. (cf. op. cit., p. 589).
} 
Percebe-se, assim, que o efeito material de ineficácia de eventual ato de disposição do bem penhorado perante o Juízo da execução decorre do vínculo processual, de Direito Público, que a penhora impõe sobre o bem.

Não se perca de vista, contudo, como pudemos verificar no capítulo 3.4.2.2. acima, a constatação de que o método de apreensão de bens incorpóreos pode atingir o próprio poder de disposição do executado sobre o bem. É o caso do dinheiro depositado em Banco, da aplicação em instituição financeira, do valor mobiliário em circulação no mercado, etc.. Em todos estes casos, em razão da natureza dos bens objeto de penhora, mais do que a ineficácia de eventuais atos de disposição, a penhora implica em medidas que obstam a prática pelo executado de atos de disposição do bem penhorado.

\subsubsection{Efeitos sobre a posse do bem e poderes correlatos}

No caso dos bens corpóreos, pode-se falar em perda de posse e dos poderes de gozo, havendo certas variações em função do modo de apreensão, se real ou ficta, como veremos a seguir.

Se a apreensão for real, o executado deixa de exercer a posse direta sobre o bem que passa a ser exercida por terceiro, pelo depositário de confiança do Juízo. ${ }^{169}$ Neste caso, o executado perde os poderes de usar $^{170}$ e gozar ${ }^{171}$ do bem, ou seja, fica impedido

\footnotetext{
${ }^{169} \mathrm{Na}$ explicação de Fábio Ulhoa Coelho "a posse direta é a titulada pelo não proprietário que, por força do contrato ou direito real, passa a possuir legitimamente algum bem". (cf. Curso de direito civil, v. 4, p. 20). Como proprietário e titular do bem, o executado passa a exercer apenas a posse indireta do bem, por força do ato de império do Estado-Juiz atuado pela penhora, ficando ao depositário o exercício da posse direta.

${ }^{170}$ Segundo Maria Helena Diniz "o direito de usar da coisa é o de tirar dela todos os serviços que ela pode prestar, sem que haja modificação em sua substância. O titular do jus utendi pode empregá-lo em seu próprio proveito ou no de terceiro, bem como deixar de utilizá-lo, guardando-o ou mantendo-o inerte. Usar do bem não é apenas retirar vantagens, mas também ter o bem em condições de servir. O jus utendi é o direito de usar a coisa, dentro das restrições legais, a fim de se evitar o abuso do direito, limitando-se, portanto, ao bem-estar da coletividade". (cf. Curso de direito civil brasileiro, p. 90-91). De acordo com Fábio Ulhoa Coelho usar significa o poder de "desfrutar dos proveitos diretamente proporcionado pelo bem. Quem mora numa casa a usa; o motorista que se locomove pela cidade num carro o está usando; uso o microcomputador quando arquivo nele as fotografias do churrasco com os amigos ou envio um correio eletrônico etc." (op. cit., p. 65).

171 Conforme Maria Helena Diniz "o jus fruendi exterioriza-se na percepção dos frutos e na utilização dos produtos da coisa. É o direito de gozar da coisa ou de explorá-la economicamente”. (op. cit., p. 91). Segundo Fábio Ulhoa Coelho "o poder de gozar (ou de fruir) o bem corresponde ao de explorá-lo economicamente, isto é, extrair dele frutos. Gozar é obter renda ou lucro da coisa. Frui do galpão, assim, que o aluga; da fazenda, o que
} 
de dar ao bem a destinação social e econômica que for de sua exclusiva conveniência, bem como de perceber os frutos produzidos pelo bem. Uma obra de arte, as pedras e metais preciosos, uma máquina agrícola, são exemplos de penhora com apreensão real. Desde a penhora, sem posse, o executado fica completamente alijado de seu uso e fruição. Voltando ao exemplo da obra de arte. Caso o Juiz determine que obra de arte seja penhorada pelo método da apreensão real o executado será imediatamente privado do uso e do gozo da coisa.

Se a apreensão for ficta, o executado continua a exercer a posse direta sobre o bem, mas em uma situação jurídica modificada. Perante o juízo da execução o executado assume o papel de depositário, o que implica no dever do executado de guardar e conservar o bem intacto até o momento da expropriação (CPC, art. 148). Nesta nova condição jurídica, o executado não fica alijado de seu poder de uso sobre o bem, na medida em que continua com o bem e pode continuar a se aproveitar dos benefícios imediatos que o bem lhe proporciona. Pode, por exemplo, continuar a morar na casa ou continuar a dirigir o automóvel. Quanto aos poderes de gozo do bem, a interpretação majoritária na Doutrina é que cabe ao executado, na condição de depositário, verter os frutos eventualmente auferidos com o bem para o juízo da execução, pois a penhora incide sobre o bem como unidade econômica integralmente considerada e pelo princípio de que o bem acessório segue o principal. ${ }^{172}$ Como argumento adicional, diz-se que o executado na condição de depositário deve agir da mesma forma que age o terceiro-depositário na apreensão real, prestando contas e vertendo os frutos produzidos pelo bem ao Juízo da execução e não os aproveitando em seu benefício particular. Esta posição doutrinária admite, de todo modo, uma ponderação de razoabilidade sobre o tema, podendo o Juiz autorizar a percepção dos frutos, total ou parcialmente, pelo executado como forma de custeio das despesas inerentes ao depósito e/ou como o equivalente à

nela planta cana-de-açúcar; da granja, o que cria frango; do terreno baldio urbano, o que o emprega no desenvolvimento de atividade empresarial de prestação de serviços de estacionamento e assim por diante" (op. cit., p.66).

${ }^{172}$ Esta é a conclusão de Araken de Assis, já analisando o tema à luz do novo Código Civil: "Não obstante, razoável se afigura, mesmo ante omissão do auto ou termo, compreender-se na penhora do solo (e imóvel por força de lei), conforme o caso: os frutos naturais, [...]; os frutos civis [...]; e os produtos [...]. Esta interpretação tutela, conforme já observava Carnelutti, a unidade econômica do imóvel, abrangendo 'todas as coisas que, de vários modos, concorrem a constituir e a completar a expressão econômica do bem penhorado, qual coisa negociável." (cf. Manual da execução, p. 599) E nos mesmo sentido Humberto Theodoro Júnior (cf. Processo de execução e cumprimento da sentença, p. 249) e José Frederico Marques (Instituições de direito processual civil, vol. V, p. 195). 
remuneração que certamente deveria ser suportada pelo exeqüente se o depósito fosse confiado à terceira pessoa. ${ }^{173}$ Ademais, se o valor do bem for inequivocamente suficiente para suportar o débito objeto de execução, nada impediria que o Juiz autorizasse a percepção dos frutos do bem pelo Executado para obstar uma penhora excessiva. ${ }^{174}$

Esta questão da percepção dos frutos, porém, por não ser regulada por disposição legal expressa gera controvérsias. A revogação pelo atual Código Civil da disposição do art. 59 do Código Civil de 1917 determinando que a coisa acessória deveria seguir a principal, pode intensificar a discussão.

Recentemente, em julgamento de 16 de novembro de 2004, o Supremo Tribunal Federal, por sua Primeira Turma, no julgamento do HC n. 84.382-4, de relatoria do Ministro Carlos Britto, ${ }^{175}$ entendeu em caso de apreensão ficta de bem imóvel que “omisso o auto de penhora quanto à abrangência da constrição, não se pode entender alcançados os frutos obtidos com os alugueres", modificando entendimento contrário do Superior Tribunal de Justiça no HC 34.196-SP, ${ }^{176}$ em julgamento de $1^{\circ}$. de junho de 2004 , que se alinhava à Doutrina majoritária sobre o tema.

\footnotetext{
${ }^{173}$ Trata-se de linha similar a que expõe Araken de Assis, citando Artur Anselmo de Castro, pelo qual frutos se compreendem na constrição, "salvo explícito pronunciamento em contrário, quer para evitar que o executado fique privado dos rendimentos, quer para evitar encargos com a administração do prédio, não sendo os frutos necessários". (cf. Manual da execução, p. 596).

174 Adilson Vieira de Araújo entende que a análise da "inclusão ou não dos acessórios dentro do objeto da penhora deve ser efetuada caso a caso, analisando-se a natureza dos bens, sua divisão cômoda e principalmente seu valor em relação ao bem principal e à obrigação a ser adimplida. De tal modo que, por exemplo, não se inclua os acessórios se a coisa principal, por si só, puder responder pela dívida, evitando-se na hipótese aventada, o excesso de penhora." (cf. A Penhora na Execução Civil e suas Limitações, p. 119).

${ }^{175}$ Disponível na página do STF na internet: www.stf.jus.br.

176 Disponível na página da internet do STJ: www.stj.gov.br. Conforme trecho do voto do Ministro Relator Francisco Falcão: "Nesse panorama há que se indagar se a penhora constituída sobre o imóvel alcança os frutos civis dela decorrentes. Tenho que na hipótese presente a penhora deve recair sobre os alugueres, porquanto o depositário, efetivamente, perdeu a posse direta do bem, possuindo-o em nome de outrem, assim ao alugar tal bem agiu como depositário, devendo solicitar ao juízo da execução a permissão para efetuar o contrato, do qual resultariam frutos civis em favor do executado em detrimento do exeqüiente". É muito interessante também o voto do Ministro Teori Albino Zavaski: “[...] parece-me claro que, apesar da penhora ter sido feita sobre um imóvel, e também não se pode confundir penhora de imóvel com penhora de renda, a verdade é que, no caso, houve a penhora e o executado deixou de ter a posse do imóvel na condição de proprietário, passando a ter o imóvel na condição de depositário. Poderia ser ele ou terceiro. Se terceiro fosse o depositário, não teríamos a menor dúvida de que o contrato de aluguel teria sido celebrado na condição de depositário, o qual, portanto, deveria prestar contas ao juiz do dinheiro auferido em função do depósito, o que faz parte dos deveres de depositário. O fato de ser o depositário o próprio proprietário não altera essa natureza: o contrato de locação foi celebrado na condição
} 
De nossa parte, compartilhamos da visão de Pontes de Miranda. ${ }^{177}$ Como não há disposição legal expressa sobre a apreensão dos frutos pela penhora do bem principal, entendemos que duas situações configuram penhora de frutos: (a) os frutos estão expressa e inequivocamente penhorados pelos atos e termos do processo, ou (b) do modo de apreensão do bem principal decorre automaticamente a apreensão também dos frutos; tal como ocorre em penhora com apreensão real e depósito do bem em mãos de terceiro. Assim, em uma apreensão ficta de imóvel, por exemplo, não é simplesmente possível presumir que a renda de aluguel esteja abrangida na penhora, já que se tratam de frutos plenamente destacáveis da coisa principal, sendo os requisitos da penhora de renda totalmente diferentes dos requisitos da penhora de imóvel. Na dúvida, deve constar expressamente dos atos e termos do processo a penhora dos frutos.

Este mesmo raciocínio deve ser utilizado para analisar os efeitos da penhora sobre bens incorpóreos, para os quais preferimos não falar em perda de posse, ${ }^{178}$ mas

de depositário e, como tal, está sujeito à prestação de contas.”. Restaram vencidos os Ministros Luiz Fux e José Delgado.

177 Segundo o Comentarista do Código: "O Código não possui regras sobre os frutos dos bens penhorados. A solução é entender-se toda questão a respeito como de interpretação do mandado de penhora, sendo um dos elementos da interpretação o modo pelo qual se executou. Exemplo: se foi penhorado o gado, 'tantas cabeças A,B,C', e ficou como depositário o executado, esse modo da execução é elemento para se interpretar que não se penhoraram os frutos do gado; outrossim, se foi penhorado o imóvel ou estava em mora o executado. Aliter, se o gado foi retirado e entregue a outro depositário. Não se raciocine, porém, como conseqüência da posse imediata ou direta. Pergunta-se apenas: houve, ou não, também, penhora dos frutos?”. (cf. Comentários ao Código de Processo Civil, XIII, p. 246).

${ }^{178}$ Nesse sentido, por exemplo, Fábio Ulhoa Coelho entende que o conceito de posse não pode se aplicar aos bens incorpóreos: "Só os bens corpóreos podem ser objeto de posse: os incorpóreos não. [...] Considera-se que podem ser possuídos, unicamente os bens suscetíveis de apreensão material. Embora a posse seja exercitável independentemente da apreensão (como no caso do engenheiro agrônomo que, a distância, define como deverá ser explorada a fazenda), não se reputa caracterizada essa específica relação de sujeição quando a coisa usada, fruída ou disposta não é corpórea. [...] Também os direitos não podem ser objeto posse, como muito se discutiu no passado. Para Moreira Alves, o emprego da palavra 'posse' em referência a relações jurídicas estranhas ao direito real - ele cita o exemplo da posse de estado - não tem em vista qualquer manifestação exterior da propriedade ou direito aos interditos, traduzindo, portanto, unicamente uma analogia." (cf. Curso de direito civil, v. 4, p. 15-16). Em sentido contrário, por exemplo, Vicente Rao, citado por Guido Arzua: “ [...] posse não é o poder físico sobre a coisa, e sim o exercício, a exterioridade de um direito, eis a noção que mais clara aparece, até a evidência, ao estudar-se a posse dos direitos" (cf. Posse - O direito e o processo, p. 38). No Direito Português, "quando a penhora incide sobre o objecto corpóreo dum direito real (penhora de bem imóvel, penhora de bem móvel, penhora de quota em bem indiviso), a transferência dos poderes de gozo importa uma transferência de posse. Cessa a posse do executado e inicia-se uma nova posse pelo tribunal: o depositário passa, em nome deste, a ter a posse do bem penhorado. Estando em causa um direito de natureza diferente (direito de crédito, direito de real de aquisição, direito a quinhão numa universalidade, direito a quota em sociedade, direito potestativo, direito real sobre coisa incorpórea), já não se pode falar em posse (cf. art. $1521 \mathrm{CC}$ ), mas continua a verificar-se a 
apenas em perda dos poderes de gozo. Dependerá de cada situação concreta verificar se dos atos de apreensão decorrem automaticamente a apreensão também dos frutos. No caso de penhora de dinheiro, é inequívoco pelo método de apreensão com depósito em instituição bancária que os juros provenientes daquele dinheiro, do bem principal, estão vinculados à penhora. Já no caso de ação de emissão de sociedade anônima a abrangência dos frutos, tais como dividendos, pelo ato de penhora do bem principal já não é tão evidente, conforme analisaremos com mais vagar no capítulo em que tratamos da penhora de ações. ${ }^{179}$

\subsection{Formalização da Penhora}

Nos capítulos anteriores, colocamos ênfase sobre o conteúdo do ato de penhora, em sua relação com seu objeto. Neste capítulo vamos tratar da forma pela qual o ato de penhora deve se exteriorizar nos autos do processo, para ser válido nos termos da Lei. ${ }^{180}$

No caso de penhora de bens corpóreos, feita a apreensão e o depósito dos bens do executado, a penhora deve ser necessariamente formalizada por um auto de penhora (CPC, art. 664). Do auto de penhora deve constar (a) o dia, mês, ano e lugar em

transferência do executado para o tribunal, dos poderes de gozo que integram o direito". (cf. José Lebre de Freitas, A Acção executiva, p. 264). Por fim, Araken de Assis com apoio em citação de Pontes de Miranda: "não há tomada de posse, salvo dos documentos-pertenças”. (Manual da execução, p. 622).

${ }^{179}$ Em oposição, na Doutrina Portuguesa, sempre, segundo José Lebre de Freitas, a penhora acarreta ao titular do bem incorpóreo perda dos poderes de gozo: "Pela penhora, o direito do executado é esvaziado dos poderes de gozo que o integram, os quais passam para o tribunal, que, em regra, os exercerá através do depositário. Quando a penhora incide sobre o objeto corpóreo dum direito real (penhora de bem imóvel, penhora de bem móvel, penhora de quota em bem indiviso), a transferência dos poderes de gozo importa uma transferência de posse. Cessa a posse do executado e inicia-se uma nova posse pelo tribunal: o depositário passa, em nome deste, a ter a posse do bem penhorado. Estando em causa um direito de natureza diferente (direito de crédito, direito real de aquisição, direito a quinhão numa universalidade, direito a quota em sociedade, direito potestativo, direito real sobre a coisa incorpórea), já não se pode falar em posse do bem penhorado. Estando em causa um direito de natureza diferente (direito de crédito, direito real de aquisição, direito a quinhão numa universalidade, direito a quota em sociedade, direito potestativo, direito real sobre coisa incorpórea), já não se pode falar em posse (cf. art. 1251 CC), mas continua a verificar-se a transferência do executado para o tribunal, dos poderes de gozo que integram o direito". (A acção executiva, p. 264).

180 Segundo Artur Anselmo de Castro "a prática do ato processual de harmonia com o esquema previsto pelo legislador faz com que ele se deva ter como perfeito. E, sendo assim, será inteiramente irrelevante, e até injustificável, toda a indagação tendente a determinar qualquer desajustamento entre o acto e a função que lhe é assinalada dentro do complexo mecanismo do processo, isto é, qualquer irrespondência entre o acto e a causa". (cf. Direito processual civil declaratório, p. 27). 
que foi feita; (b) os nomes do exequente e do executado; (c) a descrição dos bens penhorados e (d) a nomeação do depositário dos bens (CPC, art. 665). Os artigos 652, § $1^{\circ}$., 680 e 681 do Código de Processo Civil, na nova redação da Lei n. 11.382/2006, determinam ainda que o Oficial de Justiça faça avaliação do bem penhorado que deverá integrar o auto de penhora. Esta já era a sistemática adotada pela Lei de Execução Fiscal (Lei n. 6.830/80, art. 13). Sobre a avaliação, entende Araken de Assis excessiva a formalidade de produção de um laudo, prevista no art. 681 do Código de Processo Civil, "bastando o oficial de justiça, após a descrição do bem (art. 665, III), indicar o valor apurado". ${ }^{181} \mathrm{~A}$ isso acrescentaríamos que deve o Oficial de Justiça ao menos informar no auto, ainda que de maneira sucinta, os critérios que permearam sua avaliação.

$\mathrm{O}$ auto de penhora deve ser assinado pelo Oficial de Justiça e, embora a Lei não determine expressamente, deve ser assinado também pelo depositário, ${ }^{182}$ seja ele o próprio executado no caso de apreensão ficta, seja terceiro no caso de apreensão real, pois só assim é aperfeiçoado juridicamente o depósito do bem penhorado e é firmada a responsabilidade do depositário de guardar e conservar o bem até o momento da expropriação, sob pena de sofrer as conseqüências legais. ${ }^{183}$ Note-se que nos casos de apreensão ficta, ainda que o executado não esteja presente no momento da penhora para assinar o auto, será no momento da intimação da penhora (CPC, art. 668) que o executado assume a condição de depositário. ${ }^{184}$

Contudo, podem existir variações na maneira de formalização do depósito, sempre a depender das características do bem penhorado e do método de apreensão a

\footnotetext{
181 cf. Araken de Assis (Manual da execução, p. 613).

182 Trata-se do entendimento doutrinário. cf. Araken de Assis (Manual da Execução, p. 613), Arnaldo Marmitt (A Penhora - doutrina e jurisprudência, p. 44/45), José Carlos Barbosa Moreira ( $O$ novo processo civil brasileiro, p. 240/241) e Luiz Carlos de Azevedo (Da penhora, p. 202).

${ }^{183}$ Segundo Luiz Carlos de Azevedo: "O auto é de penhora e depósito, devendo completar-se necessariamente, este e aquela, sob pena de nulidade; na verdade, não se pode afirmar que a penhora houve, se o bem não foi objeto de apreensão, e se não permaneceu, daí por diante, à disposição da justiça, em mãos do depositário que assumiu o encargo, seja ele devedor ou terceiro. A assunção desta responsabilidade, como depositário fiel do bem. constitui condição para o aperfeiçoamento e validade do auto de penhora e depósito". (Da Penhora, p. 202). ${ }^{184}$ Note-se, contudo, que o executado não é obrigado a aceitar o encargo de depositário, pois não há obrigação legal neste sentido. Conforme julgado do Superior Tribunal de Justiça (RESP 488.220-ES, $4^{\mathrm{a}}$. Turma, Rel. Min. Ruy Rosado de Aguiar, DJU 25.8.2003) citado por Araken de Assis: " Se o devedor se recusa a assiná-lo ... cumpre completar o ato com a nomeação e o compromisso de terceiro". (Manual da execução, p. 613).
} 
este mais aderente. No caso de imóvel, por exemplo, independentemente de onde se localizar, a apreensão se dá por termo nos autos, ou seja, lavrada pelo próprio escrivão em Cartório, podendo o executado ser constituído depositário pessoalmente ou por meio de intimação do advogado constituído nos autos. Há nesta última situação dispensa pela Lei da assinatura do depositário para o aperfeiçoamento jurídico do depósito (CPC, art. $659, \S 5^{\circ}$.).

No caso de penhora de "crédito", decorre da análise da lei que o auto de penhora e depósito só deve ser lavrado no caso de haver apreensão física pelo Oficial de Justiça de documentos representativos do crédito. Do contrário, o art. 671 do Código de Processo Civil determina que a penhora reputa-se realizada pelas intimações previstas no art. 671, incisos I e II do Código de Processo Civil. ${ }^{185}$ O conceito aqui é oriundo do Direito Civil pelo qual o depósito pressupõe guarda de coisa corpórea. ${ }^{186}$

De fato, não há como vislumbrar depósito do "crédito", mas há bens imateriais que são passíveis de depósito. Trata-se dos chamados bens escriturais, cuja existência é comprovada pelos registros nos livros do depositário do bem. O exemplo mais evidente é o dinheiro, que assume forma escritural nos registros das contas de depósito das instituições financeiras. É certo que se trata de um contrato de depósito sui generis, não há apreensão física da coisa, trata-se de bem fungível, mas o fato é que a instituição bancária responde pela restituição do valor depositado e é obrigada a fazê-lo assim que solicitado pelo depositante. ${ }^{187}$ Há evidentemente guarda e custódia do dinheiro escritural pelo Banco em nome do depositante. Outros exemplos de bens escriturais são dados por determinados tipos de valores mobiliários, como as "ações", as quais não mais se corporificam em documentos e sim em registros existentes nas companhias ou em bancos e são passíveis de guarda e custódia por terceiros. ${ }^{188}$ Nestes casos, se não há o depósito na sua modalidade tradicional, de guarda física de bem corpóreo infungível, há depósito no sentido de guarda e custódia de bens e valores pelo depositário com obrigação de restituição a qualquer tempo, mediante solicitação do

\footnotetext{
${ }^{185}$ Segundo Araken de Assis, o termo inicial da penhora se dá com a intimação do devedor do executado (debitor debitoris)" (Manual da execução, p. 642).

186 cf. Maria Helena Diniz (Curso de direito civil brasileiro, $3^{\circ}$. volume, p. 234).

${ }^{187}$ Ver neste sentido Nelson Abrão (Direito bancário, p. 112-129)

${ }^{188}$ Ver neste sentido o art. 41 da Lei das Sociedades Anônimas (Lei n. 6.404/76) que trata dos serviços de custódia de ações fungíveis, pelos quais "a instituição tem as obrigações de depositária e responde perante o acionista e terceiros pelo descumprimento de suas obrigações" $\left(\S 5^{\circ}\right.$.).
} 
depositante. Por isso, tais bens são passíveis de depósito judicial, consistente na guarda e conservação do bem em nome do Juiz (CPC, art. 148).

Assim, para algumas espécies de bens incorpóreos, há depósito judicial. O Banco de confiança do Juízo, por exemplo, é depositário do montante penhorado em conta bancária do executado. Nestes casos, cabe formalizar auto de penhora com a indicação da instituição depositária responsável pela custódia e guarda do bem.

E ainda que o bem incorpóreo não seja passível de depósito, o Juiz deve determinar a formalização do auto de penhora, sem, logicamente, a indicação do depositário, até porque do auto, conforme já vimos, deve constar a avaliação feita pelo oficial de justiça (CPC, art. 652, § $1^{\circ}$. e art. 680). A única exceção a este respeito é o "crédito", cuja formalização, nos termos da lei, se considera feita com as intimações (CPC, art. 671).

O fato é que a variada gama de bens passíveis de penhora, com métodos de apreensão igualmente distintos, podem acarretar certas variações no ato de realização e formalização da penhora. Um exemplo já dado foi o da chamada penhora "on line”, via sistema BACEN-JUD. Muitos defendiam a ilegalidade do procedimento, sem previsão legal expressa, antes do advento da Lei n. 11.382/2006. ${ }^{189}$ No nosso entendimento, não havia ilegalidade a ser decretada, pois a premissa elementar da penhora ser determinada e controlada pelo poder jurisdicional do Estado estava mantida e a finalidade do ato cumprida. Ademais, trata-se apenas de forma tecnologicamente mais avançada de proceder à penhora do dinheiro depositado em instituição bancária. ${ }^{190}$

Vige, portanto, em relação à penhora, o princípio, aplicável a todos os atos processuais, da instrumentalidade das formas, estabelecido no art. 244 do Código de Processo Civil, pelo qual "quando a lei prescrever determinada, forma, sem cominação de nulidade, o juiz considerará válido o ato se, realizado de outro modo, lhe alcançar a

\footnotetext{
${ }^{189}$ Pela ilegalidade por ausência de previsão legal expressa, ver Guilherme Goldschmidt (A penhora on line no direito processual brasileiro, p. 67/68). Entendendo não haver ilegalidade por este motivo, ver Flávio Luiz Yarshell e Marcelo José Magalhães Bonício (cf. Execução civil: novos perfis, p. 115/120).

${ }^{190}$ cf. Flávio Luiz Yarshell e Marcelo José Magalhães Bonício (op. cit., p. 115/120).
} 
finalidade". Nesse ponto, vale citar a lição de Couture, pela qual "não há nulidade de forma se a irregularidade não tem transcendência sobre as garantias de defesa em juízo" e "não há nulidade sem prejuízo". 191

Segundo Cândido Rangel Dinamarco:

“ a consciência de que as exigências formais do processo não passam de técnicas destinadas a impedir abusos e conferir certeza aos litigantes (due process of law), mandam que elas não sejam tratadas como fins em si mesmas, senão como instrumentos a serviço de um fim. Cada ato processual tem um fim, ou escopo específico, e todos eles em conjunto têm o escopo de produzir uma tutela jurisdicional justa, mediante um processo seguro. Tal é a idéia de instrumentalidade das formas processuais, que se associa à liberdade das formas e à não taxatividade das nulidades, na composição de um sistema fundado na razão e na consciência dos escopos a realizar. Em primeiro lugar, na própria configuração do ato a lei deixa certa margem de liberdade dos sujeitos processuais (princípio da liberdade: supra, nn. 89 e 674): ao definir as consequências da inobservância da forma, renuncia ao enunciado de um rol taxativo, limitando-se a cominar umas poucas nulidades e preferindo deixar que a identificação de todas as outras se faça mediante o inteligente confronto entre o fato e o modelo a ser reproduzido nele (não-taxatividade); finalmente, manda que nesse confronto se tenha em conta escopo e jamais se afirme a nulidade quando este houver sido atingido (instrumentalidade das formas). Apoiados nesse trinômio, os sistemas modernos manifestam a consciência de que muito mais importa o escopo atingido que a forma observada, em repúdio à superada e irracional supremacia da forma sobre o fundo (supra, n. 630)."192 193

Nesse contexto, ainda que a formalização da penhora venha a apresentar discrepâncias ou mesmo contrariedades ao modelo legal, antes de se decretar a

\footnotetext{
${ }^{191}$ Trata-se de passagem citada por Humberto Theodoro Jr. (cf. "Nulidades no Código de Processo Civil" in RP 30/45).

192 cf. Instituições de direito processual civil, vol. II, p. 596-597.

${ }^{193}$ No mesmo sentido José Roberto dos Santos Bedaque ensina que "não se deve decretar a nulidade de um ato se da atipicidade não resultar prejuízo para os objetivos maiores do processo e não implicar violação dos princípios inerentes ao devido processo legal. Pela mesma razão, a adoção de vias processuais impróprias, o pedido de tutelas inadequadas - a não observância da técnica, em suma -, só devem ser consideradas relevantes se o equívoco implicar consequiências não desejadas pelo sistema. Se preservados o escopo do processo e a igualdade das partes, não há porque ser rigoroso com as exigências relativas à técnica". ( cf. Efetividade do processo $e$ técnica processual, p. 103).
} 
nulidade do ato, o Juiz deve avaliar seu conteúdo e perquirir se sua finalidade foi alcançada, sem que qualquer das partes tenha sido prejudicada pela não observância da forma legal. É usual, por exemplo, se alegar a nulidade da penhora pela falta de indicação do depositário no auto de penhora. Ora se a apreensão e o depósito se aperfeiçoaram e o depositário está de fato guardando o bem, identificada a irregularidade deve ser esta simplesmente sanada e a penhora mantida, pois inequivocamente a finalidade do ato foi alcançada, sem que qualquer das partes tivesse sido prejudicada. ${ }^{194}$ Isto, contudo, não afasta o extremo cuidado que as partes devem ter com a adequada formalização do depósito, nos casos em que tal providência for cabível, pois esta é a garantia tanto do exeqüente como do executado de que o bem penhorado será guardado e conservado até o momento da expropriação. Voltando ao nosso exemplo, de não indicação do depositário no auto de penhora, se por uma eventualidade o bem penhorado é extraviado o prejudicado não poderá tomar as medidas legais, de coerção (CPC, art. 666, $\S 3^{\circ}$.) e ressarcimento (CPC, art. 150), em face da pessoa que ficou em poder dos bens.

Assim, as partes não devem atuar de maneira a negligenciar a observância da forma legal, pois esta constitui a garantia de que uma situação jurídica está inequivocamente constituída no processo, mas caso a inobservância da forma não tenha afetado o conteúdo do ato e nenhuma das partes tenha sido prejudicada, o Juiz não deve decretar a nulidade. ${ }^{195}$

\footnotetext{
${ }^{194}$ Conforme julgado do Superior Tribunal de Justiça (RESP 90.865-MG, 4 ${ }^{\mathrm{a}}$. Turma, Rel. Min. César Asfor Rocha, DJU 25.8.1998) citado por Araken de Assis: “A ausência da nomeação do depositário no auto de penhora constitui irregularidade formal sanável, revestindo a nulidade de execução, declarada de ofício, na hipótese, em virtude de tal omissão, de excessivo rigor". (Manual da execução, p. 611). No mesmo sentido é a posição de Adilson Vieira de Araújo (cf. A penhora na execução civil e suas limitações, p. 131-132).

${ }^{195}$ Corretamente pontua José Roberto dos Santos Bedaque: "a forma estabelecida pelo legislador constitui apenas o meio adequado de assegurar o desenvolvimento adequado da relação processual, garantindo aos sujeitos parciais absoluta igualdade de condições e ampla oportunidade de participação". (cf. Efetividade do processo e técnica processual, p. 42). E mais adiante o mesmo Autor: "A má compreensão da técnica processual e da exata função da forma dos atos processuais tem impedido que o processo alcance seu objetivo maior. Estabeleceu-se verdadeiro paradoxo, pois aquilo que deveria representar garantia para o desenvolvimento adequado do instrumento acabou por transformar-se em óbice a que ele atinja seus escopos de atuação da lei e pacificação social". (cf. Efetividade do processo e técnica processual, p. 43).
} 


\subsection{Penhora e Técnica Coercitiva}

As conhecidas dificuldades que se antepõem ao credor na realização da execução forçada, a começar pela realização de uma penhora efetiva, levam a Doutrina a questionar se a utilização do mesmo regime do cumprimento das obrigações de fazer/não fazer (CPC, art. 461) e das obrigações de entregar coisa (art. 461-A), ou seja, se a plena utilização da técnica coercitiva, deveria ser estendida aos títulos executivos que contenham obrigações de pagar.

O nosso sistema processual não contempla a utilização da técnica coercitiva de impor penalidade ao devedor para impeli-lo a adimplir obrigação de pagar quantia, tal como ocorre no cumprimento das obrigações de fazer e nas obrigações de entregar coisa (CPC, art. 461 e 461-A).

Com o advento da Lei n. 11.232/2005 o art. 475-J do Código de Processo Civil passou a estabelecer multa de $10 \%$ para o devedor que não honre obrigação de pagar constante de sentença no prazo de 15 dias. Não há dúvida tratar-se de medida coercitiva que visa a compelir devedor a cumprir com sua obrigação. Contudo, o Legislador claramente não pretendeu dar às execuções de sentenças de obrigações de pagar o mesmo tratamento dado às execuções de sentenças de obrigações de "fazer" e "entregar coisa". ${ }^{196}$ Estas últimas são

\footnotetext{
${ }^{196}$ Carlos Alberto Carmona, dando seu testemunho sobre os debates prévios à realização da reforma, nos dá uma boa lição do que se pretendeu e o que se alcançou com a reforma da Lei: “ Embora a tentação fosse grande - e ainda me recordo das discussões que os membros do Instituto Brasileiro de Direito Processual mantivemos em Brasília, em agosto de 2002, quando discutimos o então anteprojeto que seria apresentado à consideração da Câmara dos Deputados (e que se transformou, anos depois, na Lei 11.232/2005, que vem de ser promulgada) -, o legislador fez uma opção moderada (moderada, não conservadora!) e preferiu uma regulamentação que mitiga as aflições da execução da sentença condenatória, simplifica os atos processuais e concede maiores poderes instrutórios ao juiz, mas não chega a introduzir em nosso sistema um novo critério (um método novo) em sede de cumprimento de sentença. É visível, portanto, a diferença entre os critérios mais elásticos que levam ao cumprimento das sentenças condenatórias de obrigações de fazer, não fazer, entregar coisa certa, e o método mais ortodoxo preconizado pela nova Lei (Lei 11.232/2005) para orientar os rumos do cumprimento das sentenças condenatórias de quantia. A própria redação do art. 475-I deixa à mostra o conflito, afirmando que o cumprimento da sentença que trata da obrigação por quantia certa deverá ser feita por execução, enquanto as demais (obrigações de fazer e entregar coisa) serão simplesmente cumpridas. Não se trata, a meu ver, de simples troca de palavras, pois os métodos são ontologicamente distintos. Tanto é assim que, enquanto as medidas tendentes ao cumprimento das sentenças condenatórias de obrigações de fazer e de entregar coisa são desde logo tomadas pelo juiz, independentemente de pedido da parte vencedora, nas sentenças condenatórias de quantia tais
} 
“cumpridas" pela técnica coercitiva (CPC, art. 461 e 461-A) e as sentenças de obrigação de pagar pela execução forçada, precedida pela multa de $10 \%$ do art. 475-J do Código de Processo Civil (CPC, art. 475-I). No que se refere a esta multa, o Legislador optou por não dar ao Juiz qualquer margem de discricionariedade, estabeleceu um percentual certo na aplicação da multa e um prazo igualmente certo para que aquela se faça incidir. ${ }^{197}$ Trata-se de situação muito diferente da ampla discricionariedade dada ao Juiz para estabelecer medidas de coerção destinadas ao implemento das obrigações de fazer (CPC, art. 461) e das obrigações de entregar coisa (CPC, art. 461-A). Para as sentenças que contenham obrigações de pagar, impõe-se a possibilidade de aplicação da multa de $10 \%$ para estimular o cumprimento das decisões judiciais; não havendo pagamento, inicia-se a execução forçada.

Pode-se, então, discutir se não seria conveniente a adoção da técnica coercitiva para a efetivação das obrigações de pagar, deixando a execução forçada como uma última opção ao Juiz, se frustradas as medidas de coerção impostas. ${ }^{198}$

A primeira questão a ser feita é quais seriam as medidas de coerção disponíveis ao Juiz para influenciar o devedor a sair de seu estado de inércia e honrar sua obrigação de pagar? A prisão civil por dívida, com exceção das alimentares, está fora de

providências dependem de pedido da parte (art. 475-J). Esta formulação revela que, embora não exista mais ação de execução, continua a existir provocação (necessária!) do vencedor para que o processo passe à fase executiva". (cf. "Novidades sobre a execução civil: observações sobre a Lei 11.232/2005" in A Nova Execução de Títulos Judiciais, p. 59/60).

${ }^{197}$ Embora ainda não seja certo o termo de início da multa. Não há clareza na Lei sobre o momento em que esta multa começa a incidir. Há muitas divergências na Doutrina, especialmente entre aqueles que defendem o seu termo inicial do trânsito em julgado da sentença e aqueles que entendem ser necessária a intimação do devedor, momento a partir do qual a multa começaria a incidir. Não faria mal nenhum para se evitar discussões intermináveis nos Tribunais sobre esta questão que o Legislador definisse claramente o termo inicial da multa. Independentemente da solução adotada, a positivação da questão seria muito mais benéfica à celeridade processual do que este estado de indefinição atual.

198 Desde já deve-se anotar ser inviável imaginar que a técnica coercitiva possa prescindir da atuação do sistema de execução forçada, mesmo nos casos de cumprimento de obrigações de fazer e entregar coisa. No Direito Brasileiro a técnica coercitiva opera usualmente pela fixação de multa pecuniária ao devedor que passa a incidir se a obrigação não é cumprida em determinado prazo e incide permanentemente até que a obrigação seja efetivamente cumprida (astreinte). Ainda que se trate de cumprimento de obrigações de fazer ou entregar coisa, caso o devedor não se sinta estimulado a cumprir a obrigação ou mesmo caso o devedor a cumpra, mas em atraso, o montante da multa incidente só poderá ser cobrado por meio da execução forçada. Assim, a execução forçada funciona como apoio ao adequado funcionamento da técnica coercitiva. É o que também ocorre com a medida coercitiva do art. 475-J do Código de Processo Civil. Não adimplida a obrigação de pagar pelo devedor no prazo de 15 dias, inicia-se a execução forçada da quantia contida na sentença, mais a multa de 10\% (dez por cento). 
cogitação no sistema constitucional brasileiro, refletindo séculos de desenvolvimento da execução até que se amadurecesse o princípio da responsabilidade patrimonial, outras vezes mencionado no curso deste trabalho. Restaria ao Juiz valer-se da astreinte para forçar o devedor a cumprir sua obrigação. Ocorre que, como bem observa Débora Baumohl, a fixação de multa periódica funcionaria como uma espécie de juros adicionais, acrescidos aos juros já incidentes sobre qualquer obrigação pecuniária (no mínimo, os juros legais), e citando Eduardo Talamini "não há razões para apostar que, sob o nome de 'multa diária', os juros teriam maior sucesso". ${ }^{199}$ Com um agravante, se o Juiz pudesse fixar multa periódica que não fosse atrelada ao conteúdo da obrigação pecuniária, poderiam ocorrer graves distorções, como multas que gerassem acréscimo à obrigação que superasse a limitação dos juros legais estabelecida no Código Civil (art. 406) ou, no caso de créditos de instituições financeiras, acréscimo que superasse as taxas de juros usualmente praticadas no mercado. Tal situação poderia dar margem a abusos e situações de enriquecimento sem causa do credor. Além do mais, o estabelecimento de multa periódica seria completamente inócuo e incapaz de causar qualquer estímulo sobre o devedor sem patrimônio para satisfazer a obrigação pecuniária em si. Se o devedor não tiver patrimônio, a técnica coercitiva, assim como a própria execução forçada, será completamente inócua e sem sentido, pois medidas de estímulo não são capazes de fazer com que o devedor realize algo que lhe é impossível cumprir.

Assim, em uma análise superficial, não nos parece adequado simplesmente transplantar a utilização da técnica coercitiva do art. 461 do Código de Processo Civil para as execuções de obrigações de pagar.

Por outro lado, não se pode esquecer que a execução forçada, como qualquer outra técnica executiva, é manifestação do poder de coerção do Estado e, portanto, se desenvolve pela prática de uma seqüência de atos estatais de coerção.

Tais atos embora não objetivem influenciar a vontade do devedor, de modo a impeli-lo a cumprir por sua própria vontade a obrigação, podem vir a ter esta

\footnotetext{
199 cf. Débora Inês Kram Baumohl (A nova execução civil - A desestruturação do processo de execução, p.139).
} 
conseqüência, pois, especialmente pela penhora, produzem efeitos processuais e materiais na esfera jurídica do devedor que geram restrições ao pleno exercício de seus direitos patrimoniais capazes de induzi-lo ao adimplemento da obrigação.

Desse modo, uma execução forçada bem aparelhada tem o efeito importante de influenciar o devedor a cumprir sua obrigação, antes que a execução forçada se inicie ou ao menos antes que a expropriação do seu patrimônio ocorra. Trata-se da coercibilidade inerente à execução forçada que pode ter o efeito indireto de estimular o devedor a cumprir sua obrigação, de modo a evitar a incidência de indesejados atos de coerção sobre o seu patrimônio. ${ }^{200}$

Estabelece-se aí evidente ponto de contato entre a execução forçada e a técnica coercitiva, com a significativa diferença de que os atos de coerção da execução forçada não se prestam à finalidade de influenciar a vontade do devedor, mas sim de expropriar seu patrimônio com o objetivo de entregar quantia ao credor, ao passo que na técnica coercitiva os atos de coerção visam única e exclusivamente influenciar a vontade do devedor, de modo a impeli-lo a cumprir a obrigação, por meio do estabelecimento de medidas coercitivas não relacionadas à obrigação objeto de cumprimento.

No nosso sistema processual, à exceção da disposição do 475-J do Código de Processo Civil, aplicável às sentenças, não há a previsão de medidas coercitivas destinadas a influenciar o devedor a cumprir obrigação de pagar. Há, contudo, medidas coercitivas destinadas a induzir a prática dos atos necessários ao adequado funcionamento da execução forçada, especialmente no que se refere ao ato de penhora.

\footnotetext{
${ }^{200}$ O ensinamento é de Luiz Carlos de Azevedo: “ E o Estado, investido que está do poder de coerção, vai tornar atuante a sanção, adotando as medidas necessárias para que o credor obtenha a integral satisfação do seu crédito. Estas medidas trazem uma finalidade: dar ao credor o que este tem direito; e se desenvolvem por meio de atos coativos, determinados pela autoridade judicial, realizando-se estes independentemente da vontade do devedor; não obstante, pelas consequências que tais atos causarão ao patrimônio do devedor, poderão induzi-lo a mudar de idéia, evitando a tempo a expropriação do bem sujeito ao juízo da execução. Também aqui, então, se observa a coercibilidade fim, tendente à reparação do equilíbrio abalado e tendente ao cumprimento do ordenamento jurídico; e também se observa a realização de atos-meio de coação, não propriamente no sentido de força física, pois só excepcionalmente esta se exercerá sobre a pessoa do obrigado (alimentante ou depositário infiel), mas de força psicológica, para que este seja compelido ao pagamento antes de ver seu bem definitivamente expropriado pelo poder sancionatório do Estado." (Da penhora, p. 111).
} 


\subsubsection{O caráter coercitivo do regime dos atos atentatórios à dignidade da justiça}

Sob a designação de "atentatório à dignidade da justiça", o art. 600 do Código de Processo Civil estipula um rol de atos que o executado não pode praticar, sob pena de incidir em multa de até $20 \%$ do valor atualizado do débito (CPC, art. 601). Em síntese, são atos de esvaziamento patrimonial, bem como de resistência ou oposição injustificadas ao regular andamento da execução. Trata-se de espécie de litigância de má-fé (CPC, art. 17) que não prejudica apenas o exeqüente, mas também o funcionamento da jurisdição. É o equivalente do Direito Processual Brasileiro à conhecida figura do "contempt of court" do Direito Anglo-Saxão (desrespeito à dignidade ou autoridade da corte).

Para tratar deste tópico, uma breve e sucinta comparação com o sistema processual norte-americano pode ajudar. Naquele sistema o "contempt" pode ser de natureza civil ou criminal. Em regra, o "civil contempt" ocorre pela desobediência de uma ordem judicial dada em benefício da outra parte do processo; o "criminal contempt" representa um ato deliberado de desrespeito à autoridade judicial. Contudo, nem sempre é possível definir o "civil contempt" ou "criminal contempt" pela natureza do ato ofensivo, até porque um mesmo ato pode caracterizar ao mesmo tempo um "civil contempt" e um "criminal contempt". Por isso, diz-se que será o tipo de processo que define se determinado ato é um “civil contempt" ou um "criminal contempt". O "civil contempt" é apurado no processo civil em que foi praticado e seu objetivo é compensar a parte prejudicada pelo ato ofensivo ou compelir o ofensor a atender à ordem descumprida. Para tanto, o Juiz pode determinar que o ofensor pague uma indenização à outra parte, bem como pode determinar a prisão ou estabelecer uma multa para que o ofensor seja compelido a praticar o ato desobedecido. Caso o ato seja finalmente praticado, o ofensor se livra do pagamento da multa ou da prisão. Já o "criminal contempt" é apurado em processo autônomo criminal, com todas as garantias inerentes ao processo criminal, com direito ao julgamento pelo júri, a não ser em caso de 
ofensas menores, e seu objetivo é punir o infrator e desencorajar a prática de atos semelhantes. $^{201}$

Sem desconsiderar as diversas ressalvas a serem feitas ao se comparar sistemas jurídicos bastante distintos, como o norte-americano da tradição da "common law" e o brasileiro da "civil law", nos parece ser possível estabelecer um paralelo didático entre o "civil contempt" e o ato atentatório à dignidade da justiça, bem como entre o "criminal contempt" e o crime de desobediência à ordem judicial, capitulável no art. 330 do Código Penal.

E tal comparação serve para evidenciar, em oposição ao sistema norte-americano, a rarefeita aplicação de penas pelos Juízes pela prática de atos atentatórios à dignidade da justiça, e a muito mais rara persecução penal pela prática de crimes de desobediência à ordem judicial. Em verdade, no que se refere ao crime de desobediência, o arcabouço jurídico legal, jurisprudencial e doutrinário brasileiro está longe de permitir a adequada repressão de condutas de desrespeito à autoridade judicial. Mais recentemente alguns Processualistas vem percebendo a importância do tema, a partir da constatação de que "a perspectiva de cometer crime e ser punido serve para induzir ao pronto cumprimento do comando judicial. Reflexamente, portanto, a sanção penal pode funcionar como meio de coerção processual civil." 202203

\footnotetext{
${ }^{201}$ Esta explicação sobre o "contempt" no direito norte-americano foi baseada nas obras dos seguintes autores: Kevin M. Clermont (cf. Principles of civil procedure, p. 117) e de Jack H. Friedenthal, Mary Kay Kane e Arthur R. Miller (Civil procedure, p. 752-756).

${ }^{202}$ Esta constatação é de Eduardo Talamini (“Ainda sobre a prisão como 'execução indireta': a criminalização da desobediência a ordens judiciais" in Processo de Execução, v.2, Sergio Shimura e Teresa Arruda Alvim Wambier, coords., p. 286). Débora Inês Kram Baumohl faz também referência a esta afirmação de Eduardo Talamini ao abordar e ressaltar a importância do tema da incriminação do descumprimento de ordens judiciais e suas repercussões no processo civil. Em nota, a Autora menciona palestra de Flávio Luiz Yarshell, no âmbito da IV Jornadas de Direito Processual Civil, na qual este propôs "que fossem consultados, quanto ao tema, os penalistas, com vistas a tornar mais eficaz qualquer proposta legislativa no sentido de incriminar o descumprimento de ordens judiciais para além do art. 330 do Código Penal". (A nova execução civil - A desestruturação do processo de execução, p.145).

${ }^{203}$ Chega à conclusão similar o Professor Norte-Americano Kevin M. Clermont: "Criminal contempt is not, strictly speaking, a means of enforcement of judgment, but the possibility of criminal contempt incidentally benefits the plaintiff by encouraging compliance with the judgment". (op. cit., p. 117).
} 
No que se refere ao ato atentatório à dignidade da justiça do art. 600 do Código de Processo Civil, o nosso "civil contempt", o arcabouço jurídico está dado ao Juiz que tem à sua disposição medidas de coerção para demover o executado de praticar atos fraudulentos (inciso I), bem como atos de má-fé para se opor ou resistir injustificadamente à execução (incisos II e III), e a partir da Lei n. 11.382/2006, para impelir o executado a indicar bens sujeitos à penhora e seus respectivos valores (inciso IV). ${ }^{204} 205$

Verificado pelo Juiz, por provocação do exeqüente ou de ofício, que o Executado praticou ato atentatório à dignidade da justiça, segundo a Doutrina, deve o Juiz necessariamente "advertir ao devedor que seu procedimento constitui ato atentatório à dignidade da justiça" (CPC, art. 599, II). Tal providência serve para induzir o executado a se retratar, no caso de ato comissivo, revertendo a situação fática por ele criada, e no caso de ato omissivo, colaborando com a justiça, sob pena de sofrer penalidade pecuniária de até $20 \%$ do valor atualizado do débito, estando ainda sujeito a pagar indenização pelos eventuais prejuízos sofridos pelo exequente (CPC, art. 18). ${ }^{206} \mathrm{E}$ ainda que a pena seja aplicada pelo Juiz, o executado tem a possibilidade de afastar sua incidência, caso preencha concomitantemente duas condições: (a) se comprometa a não mais praticar quaisquer atos atentatórios (b) e, mais importante, se der fiador idôneo, que responda ao credor pela dívida principal, juros, despesas e honorários advocatícios (CPC, art. 601, parágrafo único).

Assim, o regime dos "atos atentatórios à dignidade da justiça” pode se constituir em importante instrumento coercitivo para impelir o executado a não obstruir

\footnotetext{
${ }^{204}$ Esta disposição reforça o poder dado ao Juiz pelo art. $652, \S 3^{\circ}$., do Código de Processo Civil: “O juiz poderá, de ofício ou a requerimento do exequente, determinar, a qualquer tempo, a intimação do executado para indicar bens passíveis de penhora".

${ }^{205}$ Cabe notar que sobre a égide do regime anterior já se defendia que a não indicação pelo devedor de seus bens passíveis de penhora caracterizaria "ato atentatório à dignidade da Justiça", por se caracterizar em ato de frustração aos desígnios da Jurisdição, em uma interpretação mais abrangente da expressão "fraude à execução" constante do art. 600, inciso I, do Código de Processo Civil. (cf. Alberto Camiña Moreira, "Ato atentatório à dignidade da justiça. Não nomeação de bens à penhora", in Processo de Execução, v. 2, Sergio Shimura e Teresa Arruda Alvim Wambier, coords., p. 13-27). Em sentido não idêntico, mas similar, posicionamento do extinto $1^{\circ}$. Tribunal de Alçada Civil de São Paulo ainda nos idos de 1976, fazendo referência ao art. 600, inciso IV, do CPC, na sua redação anterior: "Aliás, a lei, de modo expresso, considera atentatória à dignidade da Justiça a omissão do devedor, quanto à indicação de bens sujeitos à execução”. (RT 489/152). Na mesma linha deste acórdão, julgado do STF, RT 596/280.

${ }^{206}$ Ver neste sentido Araken de Assis (cf. Manual da execução, p. 328-333) e Humberto Theodoro Júnior (cf. Processo de execução e cumprimento de sentença, p. 178-180).
} 
indevidamente a prática dos atos executivos e até mesmo a colaborar com a execução, listando ao Juiz seus bens passíveis de penhora, desde que os operadores do direito tomem consciência de sua funcionalidade.

Primeiro, adverte-se o executado sobre a prática de ato atentatório. Advertido, o executado terá consciência de que, caso não se retrate da situação fática por ele criada ou de sua omissão em não indicar bens passíveis de penhora, sofrerá punição. Há assim o caráter coercitivo de impelir o executado a colaborar ou ao menos não obstruir indevidamente a execução, sob ameaça de ser punido. $\mathrm{O}$ objetivo maior do Legislador é garantir que a execução tenha seu curso normal e seja efetiva. Tanto é este o objetivo do Legislador que a pena aplicada será relevada se o executado der fiador idôneo à integral satisfação do crédito. Como pudemos apreender da experiência norte-americana, o nosso “civil contempt", previsto no art. 600 do Código de Processo Civil tem finalidade coercitiva, o que resulta claro do procedimento legal de aplicação da penalidade pela prática do ato atentatório. Por isso, em nossa opinião, seria desnecessária a criação de novas disposições legais prevendo a "aplicabilidade da multa de caráter coercitivo para impingir ao executado o cumprimento de deveres instrumentais à consecução de medidas originalmente subrogatórias". ${ }^{207}$

\subsubsection{A prisão do depositário infiel}

Como já vimos, a penhora do bem corpóreo só se aperfeiçoa com o depósito. A guarda e conservação dos bem penhorados pelo depositário até o momento da expropriação, seja ele o executado, o exequente ou terceiro (CPC, art. 148), é um dos deveres instrumentais correlatos ao adequado funcionamento da execução forçada. Trata-se de função de caráter público, pela qual o depositário assume a condição de auxiliar da Justiça. ${ }^{208}$

\footnotetext{
${ }^{207}$ Trata-se de sugestão de Débora Inês Kram Baumohl, com apoio em outros Doutrinadores. (A nova execução civil - A desestruturação do processo de execução, p.139).

${ }^{208}$ Segundo Humberto Theodoro Júnior em trecho de obra na qual cita Gian Antonio Micheli: “Assim, usa a lei de dois expedientes para assegurar a conservação da coisa penhorada: juridicamente torna ineficaz as transferências dominiais do devedor sobre a coisa; e, fisicamente, submete a mesma coisa a uma custódia obrigatória, 'depósito esse que pode ser atribuído a um terceiro, ao próprio credor, ou também ao devedor, mas que, em qualquer caso, investe o sujeito de particulares poderes (de caráter público), que o colocam junto ao juiz, como seu auxiliar"'. (cf. Processo de execução e cumprimento de sentença, p. 303).
} 
É da tradição do ordenamento jurídico brasileiro prever a medida coercitiva de prisão ao depositário que não restitui a coisa que está sob o seu poder, o depositário infiel. Tanto é assim que o art. $5^{\circ}$., inciso LXVII, da Constituição Federal estabelece o seguinte: "não haverá prisão civil por dívida, salvo a do responsável pelo inadimplemento voluntário e inescusável de obrigação alimentícia e a do depositário infiel".

Contudo, desde a ratificação pelo Brasil por meio do Decreto Legislativo n. 27, de 26.5.1992, da Convenção Americana sobre Direitos Humanos (Pacto de San José da Costa Rica) de 22 de novembro de 1969, iniciou-se uma discussão jurídica, bastante controversa na doutrina e na jurisprudência, a partir da tese de que o Pacto de San José da Costa Rica introduzido no ordenamento jurídico brasileiro vedaria a prisão do depositário infiel, em função da disposição do $\S 7^{\circ}$. do artigo $7^{\circ}$ que trata do "direito à liberdade pessoal" segundo a qual: "ninguém deve ser detido por dívidas. Este princípio não limita os mandados de autoridade judiciária competente expedidos em virtude de inadimplemento de obrigação alimentar".

Segundo os defensores desta tese, apenas o inadimplemento da obrigação alimentar poderia gerar prisão civil, o que afastaria a possibilidade de prisão do depositário infiel, ainda que prevista constitucionalmente. Isto porque, o Pacto de San José da Costa Rica neste ponto veicularia direito e garantia fundamental da pessoa humana com status constitucional, nos termos do que dispõe o $\S 2^{\circ}$. do artigo $5^{\circ}$. da Constituição Federal, pelo qual "as normas decorrentes de tratados internacionais veiculadoras de direitos e garantias ingressam no ordenamento jurídico brasileiro com grau hierárquico constitucional". ${ }^{209}$

Até bem pouco tempo atrás jurisprudência predominante do Supremo Tribunal Federal e do Superior Tribunal de Justiça rejeitava a tese da não admissibilidade da prisão civil do depositário infiel, em razão do ingresso no ordenamento jurídico brasileiro do Pacto de San José da Costa Rica.

\footnotetext{
${ }^{209}$ cf. Débora Inês Kram Baumohl (A nova execução civil - A desestruturação do processo de execução, p.141).
} 
No Supremo Tribunal Federal, esta questão primeiramente emergiu na análise do depósito decorrente da relação contratual do instituto da alienação fiduciária em garantia do Decreto-Lei n. 911/69. No julgamento do HC n. 72.131-RJ, em 23 de novembro de 1995, vencido o Ministro Relator Marco Aurélio e figurando o Ministro Moreira Alves como Relator para acórdão, o pleno do Supremo Tribunal Federal por maioria rejeitou o status constitucional do Pacto de San José da Costa Rica e manteve a possibilidade de prisão civil do depositário infiel. Este posicionamento foi mantido, também por maioria, no julgamento plenário de 27 de maio de 1998 no âmbito do RE n. 206.482-3, com relatoria do Ministro Maurício Corrêa. ${ }^{210}$

Da mesma forma, no que se refere ao depositário de bem penhorado, que funciona como auxiliar do Juízo, o Supremo Tribunal Federal sempre admitiu a prisão civil daquele que exerce infielmente seu encargo. Por ser basilar, vale transcrever neste sentido trecho do voto do Ministro Celso de Mello na condição de Relator do recurso ordinário em Habeas Corpus n. 80.035-1/SC, 2 ${ }^{\mathrm{a}}$. Turma, julgado em 21 de novembro de 2000:

“ [...] Não obstante a sua formal condição de depositário judicial de tais bens, o ora recorrente não foi capaz de cumprir uma de suas obrigações legais a que estava sujeito, consistente do dever de entregar e restituir , ao juízo da execução, os bens objeto da penhora $[\ldots]$.

O paciente recorrente, enquanto depositário judicial dos bens penhorados em processo de execução, ao assim proceder, agiu em desconformidade com os deveres éticos-juridicos que se revelam inerentes ao encargo processual de quem recebe, na qualidade de auxiliar do juízo, a custódia de valores e de coisas objeto do ato de constrição judicial.

O comportamento do ora paciente - que frustrou a remoção dos bens penhorados, precisamente porque não foi capaz de restituí-los em determinação do juízo da execução - infringiu o ordenamento jurídico que impõe, a quem ostenta a condição de depositário judicial, o dever de entregar as coisas em depósito.

O depósito judicial - enquanto modalidade de depósito necessário é aquele que se faz em desempenho de obrigação legal. Ao ser

\footnotetext{
${ }^{210}$ Ambos os acórdãos estão disponíveis na íntegra na página da internet do STF (www.stf.jus.br).
} 
efetivado - assinala o magistério da doutrina (JOSÉ FREDERICO MARQUES, "Manual de Direito Processual Civil", vol IV/164-165, item n. 866, $7^{\text {a }}$. ed., 1987, Saraiva; VICENTE GRECO FILHO, "Direito Processual Civil Brasileiro", vol. 3/76, item 12.2., 5a. ed., 1989, Saraiva, v.g.) - , o depósito judicial estabelece típica relação de direito público, de caráter processual entre o Estado (representado pela autoridade judiciária que dirige o processo de execução) e o depositário judicial dos bens penhorados, que passa a qualificar-se como órgão auxiliar do juízo.

\section{$[\ldots]$}

Torna-se evidente, pois, que o desvio patrimonial dos bens penhorados, quando praticados pelo depositário judicial ex voluntae propria e sem autorização prévia do juízo da execução, caracteriza situação configuradora de infidelidade depositária, apta a ensejar, por si mesma, a possibilidade de decretação, no âmbito do processo de execução, da prisão civil desse auxiliar de juízo.

$[\ldots]$

Cabe enfatizar neste ponto, que a prisão civil do depositário judicial, além de não transgredir a Constituição da República, também não ofende o sistema de proteção instituída pela Convenção Americana sobre Direitos Humanos (Pacto de São José da Costa Rica).

$[\ldots]$

É inquestionável, dentro do sistema jurídico brasileiro, que a normatividade emergente dos tratados internacionais permite situar tais atos de direito internacional público, no que concerne à hierarquia das fontes, no mesmo plano de eficácia em que se posicionam as leis internas de caráter meramente ordinário, como reconhece a jurisprudência do Supremo Tribunal Federal (RTJ 58/70 - RTJ 83/809 - ADI 1480-DF, Rel. Min. Celso de Mello) e acentua o magistério da doutrina (JOSÉ ALFREDO BORGES in Revista de Direito Tributário, vol. 27/28, p. 170-173; FRANCISCO CAMPOS, in RDA 47/452; ANTÔNIO SAMPAIO DÓRIA, "Da lei tributária no tempo", p. 41, 1968; GERALDO ATALIBA, "Apontamento de Ciências das Finanças, Direito Financeiro e Tributário", p. 110, 1969, RT; IRINEU STRENGER, "Curso de Direito Internacional Privado" p. 108/112, 1978, Forense; JOSÉ FRANCISCO REZEK, "Direito dos Tratados", p. 470-475, itens 393-395, 1984, Forense, v.g.). 
Inexiste, contudo, na perspectiva do modelo constitucional vigente no Brasil, qualquer precedência ou primazia hirárquico-normativa dos tratados ou convenções internacionais sobre o direito positivo interno, sobretudo em face das cláusulas insertas no texto da Constituição da República, eis que a ordem normativa externa não se superpõe, em hipótese alguma, ao que prescreve a Lei Fundamental da República.

Impende salientar, por tal razão, que a cláusula inserta no art. $7^{\circ}$., n. 7, da Convenção Americana sobre Direitos Humanos - não obstante haver omitido qualquer referência normativa à possibilidade da decretação da prisão civil do depositário infiel - nem por isso terá o condão de vincular o legislador constituinte ao alcance de suas disposições. [...]". ${ }^{211}$

Sobre esta questão, não se pode deixar de mencionar a Súmula 619 do Supremo Tribunal Federal, pela qual se autoriza "a prisão do depositário judicial no próprio processo em que se constituiu o encargo, independentemente da propositura de ação de depósito".

O Superior Tribunal de Justiça, por sua vez, no que se refere à prisão civil do depositário infiel de bem penhorado, também chamado depositário judicial, sempre seguiu o entendimento do Supremo Tribunal Federal. Nesse sentido, a posição majoritária da jurisprudência do Superior Tribunal de Justiça tem entendido que "a restrição à prisão civil apregoada pelo Direito Internacional -Pacto de São José da Costa Rica circunscreve-se à prisão civil por dívida oriunda de contrato, e não à decorrente de descumprimento de munus público ordenada por decisão judicial". ${ }^{212}$

Nesse contexto, a Lei 11.282/2006 ao introduzir o $\S 3^{\circ}$. no art. 666 do Código de Processo Civil, simplesmente transformou em disposição legal interpretação do ordenamento jurídico que já era pacífica nos Tribunais Superiores. Segundo o referido

\footnotetext{
${ }^{211}$ Disponível na íntegra no endereço eletrônio www.stf.jus.br.

${ }^{212}$ Trata-se de citação de Humberto Theodoro Junior fazendo referência aos seguintes julgados: "STJ, 1'. T., HC 26.738/SP, Rel. Min. Luiz Fux, ac. 06.05.2003, DJU 19.05.2003 p. 124; STJ 3a. T., Resp 292090/SP, Rel. Min. Antônio de Pádua Ribeiro, ac. 08.05.2003, DJU 09.06.2003 p. 263”. (cf. Processo de execução e cumprimento de sentença, p. 316).
} 
dispositivo legal: "a prisão de depositário judicial infiel será decretada no próprio processo, independentemente da ação de depósito".

Ocorre que no momento em que a questão parecia completamente pacificada, inclusive com positivação em lei, o Supremo Tribunal Federal, parece tre mudado sua posição histórica para reconhecer a inconstitucionalidade da prisão civil do depositário infiel, seja do alienante fiduciário seja do depositário judicial, a partir dos julgamentos pelo Tribunal Pleno do RE 466.343/SP e do HC 87585, finalizados em 3 de dezembro de 2008, cujos acórdãos ainda não foram publicados. No próprio dia 3 de dezembro de 2008 o resultado de tais julgamentos foi divulgado na página do Supremo na internet, ${ }^{213}$ tendo sido noticiado que o Supremo havia revertido seu posicionamento anterior para concluir ser aplicável a prisão civil apenas para o responsável pelo inadimplemento de obrigação alimentícia e que a Súmula 619 teria sido revogada.

E tal novo posicionamento, especificamente sobre a impossibilidade de prisão civil do depositário judicial infiel, já se refletiu pelo menos no julgamento do HC 90.172-7/SP, de relatoria do Ministro Gilmar Mendes, de 5 de junho de 2007, no âmbito da $2^{\mathrm{a}}$. Turma; e também no HC 88.240-4/SP, de relatoria da Ministra Ellen Gracie, de 7 de outubro de 2008, também da $2^{\mathrm{a}}$. Turma. Para ilustrar a fundamentação de tais acórdãos, vale transcrever trecho do voto da Ministra Ellen Gracie no HC já mencionado de sua relatoria:

“ [...] Contudo, no que tange à temática da prisão civil do depositário infiel, o enfoque foi alterado na jurisprudência desta Corte. A $2^{\mathrm{a}}$. Turma do Supremo Tribunal Federal filiou-se à orientação acerca da inexistência de sustentação jurídica para prisão civil do depositário infiel, renovando a discussão de matéria sob o prisma constitucional (HC 90.171-7/SP, rel. Min. Gilmar Mendes, DJ 17.08.2007).

\section{$[\ldots]$}

No voto do eminente Relator atualmente presidindo esta Corte, destacou-se o caráter especial do Pacto Internacional dos Direitos Civis Políticos (art. 11) e da Convenção Americana sobre Direitos

\footnotetext{
${ }^{213}$ http//:www.stf.jus.br.
} 
Humanos - Pacto de San José da Costa Rica (art. $7^{\circ} ., 7$ ), ratificados, sem reserva pelo Brasil, no ano de 1992. Esclareceu, ainda, que esses diplomas internacionais sobre direitos humanos é reservado o lugar específico no ordenamento jurídico, estando abaixo da Constituição, porém acima da legislação interna. Concluiu, assim, que o status normativo supralegal dos tratados internacionais de direitos humanos subscritos pelo Brasil, torna inaplicável a legislação infraconstitucional com ele conflitante, seja ele anterior ou posterior ao ato de ratificação.

Registro que no âmbito do HC 87.855-TO, afetado ao pleno, esta Corte já conta com oito votos no sentido da impossibilidade da prisão civil do depositário infiel, pendendo pedido de vista do Ministro Carlos Alberto Menezes Direito.

Conforme noticiado recentemente, esta $2^{\mathrm{a}}$. Turma deferiu cinco ordens de hábeas corpus no sentido de não mais admitir a possibilidade de prisão civil decretada contra depositários infiéis (HC n. 90.450/MG, 91.361/SP, 93.280/SC, 90.983/SP e 94.695/RS), tendo o Min. Celso de Mello declarado que "não mais subsiste a prisão civil em face da ordem constitucional brasileira, em depósito convencional ou judicial”, sendo que em um dos casos houve o afastamento episódico da orientação na Súmula 691 do STF.

Desse modo, na atualidade a única hipótese de prisão civil, no Direito Brasileiro, é a do devedor de alimentos. O art. $5^{\circ}$., § $2^{\circ}$., da Carta Magna, expressamente estabeleceu que os direitos e garantias expressas no caput do mesmo dispositivo não excluem outros decorrentes do regime dos princípios por ela adotados, ou dos tratados internacionais em que a República Federativa do Brasil seja parte. O Pacto de São José da Costa Rica, entendido como um tratado internacional em matéria de direitos humanos, só admite, no seu bojo, a possibilidade de prisão do devedor de alimentos e, conseqüentemente, não admite mais a possibilidade de prisão civil do depositário infiel.

Tal conclusão não impede que sejam adotadas outras medidas coercitivas para o efetivo cumprimento das obrigações decorrentes do depósito, ressalvada a impossibilidade de prisão civil." ${ }^{214}$

Na linha deste novo posicionamento do Supremo Tribunal Federal, o Superior Tribunal de Justiça dá sinais de que também está mudando sua orientação

\footnotetext{
${ }^{214} \mathrm{Na}$ íntegra no endereço http//:www.stf.jus.br..
} 
jurisprudencial para vedar a prisão civil do depositário judicial infiel. Neste sentido, mencione-se o HC 106975/RS, da $1^{\text {a }}$. Turma, com relatoria para acórdão do Ministro Luiz Fux, julgado em 19 de agosto de 2008, e também da $1^{\text {a }}$. Turma o HC 51936/SP de relatoria do Ministro José Delgado, julgado em 19 de fevereiro de 2008. ${ }^{215}$

Este novíssimo panorama sobre a questão pode transmitir a perigosa mensagem a todos que se valem do sistema processual (usuários e seus operadores) de que a gravíssima conduta de trair a confiança do juízo no exercício do encargo de depositário não traz maiores consequiências. Trata-se de mensagem conflitante com a busca de uma maior efetividade da execução forçada, inclusive pela edição da Lei n. 11.382/2006, a qual nitidamente pretendeu reforçar a possibilidade do Juiz determinar a prisão do depositário infiel (CPC, art. 666, § $3^{\circ}$.).

No nosso entender, deve-se distinguir entre a situação do depositário na alienação fiduciária em garantia, ou outras espécies de depósito convencional, e a situação do depositário do bem penhorado que, como já vimos, exerce função pública, por delegação do Juiz, de guarda e conservação do bem até o momento da expropriação. ${ }^{216}$

O depositário do bem penhorado, ou o depositário judicial como preferem alguns, estabelece uma relação com o Estado-Juiz e exerce função que, embora interesse ao exeqüente, interessa também ao Estado em sua missão de garantir aos particulares a efetiva satisfação e concretização prática de seus direitos (tutela jurisdicional satisfativa). Como já pudemos observar neste trabalho, o funcionamento do sistema de execução forçada diz respeito não só aos particulares que litigam em juízo, mas também à toda sociedade, dada as sensíveis repercussões sociais e econômicas daquele sistema.

\footnotetext{
${ }^{215}$ Os acórdãos estão disponíveis na íntegra no endereço http//:www.stj.gov.br.

${ }^{216}$ Como bem ensina Cândido Rangel Dinamarco: "O depósito de aqui se fala não é depósito convencional do direito privado; é relação de direito público, constituída pelo ato do órgão judicial que nomeia o depositário' (Liebman). Ao depositário cumpre zelar ao bom posto sob sua guarda e administrá-lo adequadamente com vista à sua conservação ou até mesmo à produção que dele for lícito esperar [...], prestando contas ao juízo quando lhe forem solicitadas". (cf. Instituições de Direito Processual Civil, p. 541).
} 
O depositário que maliciosamente deixa de restituir ao Juiz o bem penhorado atinge não só os interesses imediatos do exeqüente naquele bem, mas também atinge gravemente os desígnios da jurisdição. É conduta que trai ostensivamente a determinação judicial de guarda e conservação do bem, desrespeitando a autoridade judicial e atentando contra dignidade da justiça. ${ }^{217}$ Nessas circunstâncias, entendemos não ser excessiva a pena de prisão historicamente prevista no ordenamento jurídico brasileiro, nos exatos moldes do "civil contempt" do direito norte-americano. ${ }^{218}$ A aplicação de tal pena pelo Juiz é a maneira mais eficaz de forçar o depositário a apresentar o bem depositado ou depositar o equivalente ao valor do bem em dinheiro. ${ }^{219}$ Trata-se de medida com evidente caráter coercitivo, ${ }^{220}$ cuja intensidade se faz necessária para fazer valer o instituto do depósito na penhora, cuja proteção é vital para que a execução forçada funcione adequadamente.

De outro lado, entendemos que neste caso a prisão não decorre de dívida, mas de obrigação de caráter público assumida voluntariamente por alguém, perante o Estado, de guardar e conservar determinado bem entregue em confiança. Cabe frisar inclusive que o depositário não será sempre o executado/devedor, mas pode ser o exeqüente ou terceiro. E mesmo no caso de figurar o executado/devedor como depositário a cominação da penalidade de prisão pelo depósito infiel não decorre de sua condição de devedor, mas de sua condição de depositário que trai a confiança do Juízo da execução. E tal infidelidade do executado/devedor é ainda mais grave, pois normalmente é interesse do executado/devedor

\footnotetext{
${ }^{217}$ É basilar neste sentido o voto do Ministro Fernando Gonçalves do Superior Tribunal de Justiça no Habeas Corpus n. 91.868-MG, íntegra no www.stj.gov.br, do qual se destaca o seguinte trecho: “ [...] a prisão civil do depositário judicial além de ter o caráter coercitivo, no sentido de fazer cumprir o encargo, destina-se também a coibir e reprimir ato atentatório à dignidade da Justiça, notadamente como no caso presente, em que o depositário é próprio devedor e, mesmo assim, aliena o bem".

${ }^{218}$ Há no Direito Norte-Americano uma alegoria interessante, citada por Kevin M. Clermont, para definir esta situação: "the contemnor "carries the keys of his prision in his own pocket"” (cf. Principles of civil procedure, p. 117).

${ }^{219}$ De acordo com Araken de Assis: “A sanção do depositário infiel consiste na sua prisão pura e simples, pelo prazo não excedente a um ano (art. 652, in fine, do CC-02), cumprida em qualquer estabelecimento penal". E mais à frente: "A prisão de depositário infiel cessará tão logo ocorra a entrega do bem ou do seu equivalente pecuniário. Nesta hipótese, o juiz expedirá, imediatamente, o mandado de soltura". (cf. Manual da Execução, p. 628)

${ }^{220}$ Interessante acórdão do extinto Tribunal de Alçada Civil de São Paulo, de 7 de junho de 1972, reconhece com precisão o caráter coercitivo da pena de prisão do depositário infiel: "A prisão do depositário infiel é meramente compulsiva, com a única finalidade de obrigá-lo ao cumprimento de uma obrigação. Assim, poderá ser elidida, entregando a coisa ou o seu equivalente em dinheiro". (RT 443/258)
} 
figurar como depositário para não perder o uso e gozo imediato do bem, motivo pelo qual os Juízes, confiando na boa-fé do executado/devedor, autorizam a apreensão ficta.

Assim, sem adentrar no mérito da discussão do status hierárquico pelo qual os tratados internacionais em matéria de direitos humanos são recepcionados pela ordem constitucional brasileira, não vislumbramos na medida coercitiva de prisão do depositário infiel de bens penhorados violação ao Pacto de San José da Costa Rica, que veda prisão por dívida, e também ao Pacto Internacional dos Direitos Civis e Políticos ao estabelecer no seu art. 11 que "ninguém poderá ser preso apenas por não cumprir com uma obrigação contratual" (g.n.).

Cabe considerar ser a jurisprudência brasileira bastante parcimoniosa na autorização da prisão civil do depositário infiel, o qual deve ter assumido o encargo expressamente ${ }^{221}$ e ter agido com dolo ao não restituir o bem penhorado ao Juízo da execução. $^{222}$

Trata-se de postura equilibrada a possibilitar ao Poder Judiciário utilizar-se de medida coercitiva adequada para coibir condutas que venham a esvaziar ato instrumental essencial ao eficaz funcionamento da execução forçada.

Firmada nossa posição sobre a questão, resta aguardar a publicação pelo Supremo Tribunal Federal dos acórdãos do Tribunal Pleno que julgaram o RE 466.343/SP e o HC 87585 e os desdobramentos de tais julgamentos sobre o ordenamento jurídico brasileiro.

\footnotetext{
221 Araken de Assis pontua corretamente ser imprescindível que o depositário tenha assumido o encargo expressamente, assinando o auto de penhora. E cita a Súmula 304 do Superior Tribunal de Justiça: “É ilegal a decretação da prisão civil daquele que não assume expressamente o encargo de depositário judicial”. (cf. Manual da Execução, p. 627)

${ }^{222}$ Segundo Arthur Luis Mendonça Rollo, com base na análise de precedentes do Superior Tribunal de Justiça: “...o que determina a decretação da prisão civil do depositário é a sua relutância dolosa na restituição do bem, o que atenta contra o Estado." (cf. "Fiel depositário dos bens, deveres, conseqüências e possibilidade de prisão civil", in Execução Civil e Cumprimento de Sentença, Gilberto Gomes Bruschi, coord., p. 69).
} 


\section{TIPOS DE PENHORA}

\subsection{A penhora na realidade econômica e social atual}

No capítulo 3 deste trabalho enfatizamos a importância do ato processual de penhora ser aderente à realidade econômica e social, por métodos ou formas de apreensão condizentes à natureza e às características do bem a ser apreendido.

Não se trata de tarefa fácil. A jurisprudência é vasta e comprova que em matéria de penhora as dificuldades processuais muitas vezes decorrem das contingências e vicissitudes reais de cada situação concreta. O Tribunal de Justiça do Rio Grande do Sul, por exemplo, recentemente discutiu a possibilidade de penhora de bem de família composto de dois pavimentos, considerando um dos pavimentos penhorável, em razão da família do executado neste não residir (RT 873/311). A discussão sobre penhora do direito de uso de linha telefônica, o que hoje pareceria completamente estéril, por muito tempo foi relevante em nossos Tribunais, em um contexto em que aquele direito tinha significação econômica (RT 431/204, 533/236). O antigo debate doutrinário sobre a penhorabilidade das cotas sociais de sociedades empresariais, como veremos a seguir, deita raízes nas peculiaridades econômicas e jurídicas deste tipo de bem.

O artigo 655 do Código de Processo Civil contém rol de bens passíveis de penhora, estabelecendo uma preferência legal decrescente: "I - dinheiro, em espécie ou em depósito ou aplicação em instituição financeira; II - veículos de via terrestre; III - bens móveis em geral; IV - bens imóveis; V - navios e aeronaves; VI - ações e quotas de sociedades empresárias; VII - percentual do faturamento de empresa devedora; VIII - pedras e metais preciosos; IX - títulos da dívida pública da União, Estados e Distrito Federal com cotação em mercado; X - títulos e valores mobiliários com cotação em mercado e XI - outros direitos". 
Cada um desses bens é passível de uma específica forma de apreensão. Não iremos analisar as formas de penhora de todos os bens do rol do artigo 655 do Código de Processo Civil, mas apenas daqueles de maior relevância no contexto econômico e social atual e para os quais as execuções têm sido (ou deveriam ser) mais direcionadas atualmente.

Pois bem, a partir da análise da jurisprudência publicada no periódico Revista dos Tribunais de 1970 até 2008, como também da jurisprudência do Superior Tribunal de Justiça disponível em sua página na internet, dos dados estatísticos sobre o funcionamento do sistema BACEN-JUD fornecidos pelo Banco Central do Brasil, bem como das alterações legislativas no regime da penhora introduzidas pela Lei n. 11.382/2006, somado à nossa experiência profissional na área, é possível concluir ser hoje o dinheiro depositado em instituições financeiras e outros ativos financeiros os alvos preferenciais de penhora. Já de há algum tempo, também, a penhora de percentual de faturamento de empresa tem sido muito buscada pelos operadores do direito. No Superior Tribunal de Justiça ressurge a discussão sobre a penhora de "créditos", a partir das controvérsias sobre penhora de precatórios emitidos pelos entes da Federação. Trata-se, ademais, de modalidade de penhora, que dada a importância do "crédito" na economia atual, poderia ser muito mais utilizada na prática. ${ }^{223}$ A penhora de títulos da dívida pública tem sido também cada vez mais debatida no âmbito do Superior Tribunal de Justiça, o que naturalmente reflete uma movimentação neste mesmo sentido nos Tribunais inferiores. ${ }^{224}$

\footnotetext{
${ }^{223}$ Ver neste sentido trecho de ementa do RESP n. 938087/RS, de relatoria do Ministro Luiz Fux: "[...] A Lei $6.830 / 80$, art. $9^{\circ}$, III e art. 11 , VIII atribui ao executado a prerrogativa de nomear bens à penhora, que pode recair sobre direitos e ações. 2 . O crédito representado por precatório é bem penhorável, mesmo que a entidade dele devedora não seja a própria exeqüente. Enquadra-se na hipótese do inciso XI do art. 655 do CPC, por se constituir em direito de crédito. Não se confunde com dinheiro, que poderia substituir o imóvel penhorado independente do consentimento do credor. Precedente: (REsp 893519/RS, DJ 18.09.2007 p. 287 ) 3. Consequentemente, admite-se a nomeação, para fins de garantia do juízo, de crédito consubstanciado em precatório, máxime por suas características de certeza e liquidez, que se exacerbam quando o próprio exeqüente

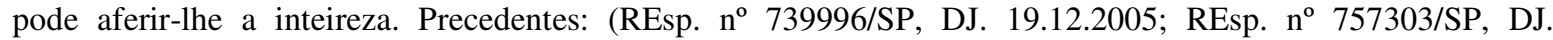
26.09.2005; AgRg no REsp 434.722/SP) [...]." (DJ, 14/04/2008. A íntegra do acórdão é acessível no endereço eletrônico http//www.stj.gov.br).

${ }^{224}$ Embora normalmente para rejeitar o oferecimento de títulos da dívida pública por falta de cotação em mercado e ausência de liquidez, tal como se verifica da ementa do RESP n. 951543/GO, de relatoria do Juiz Federal Convocado Carlos Fernandes Mathias: "[...] A recusa de bens oferecidos à penhora, in casu, títulos da dívida pública - Letras Financeiras do Tesouro - LFT - revela-se legítima, sem que haja malferimento do art. 620 do CPC, máxime ante a iliquidez do título e porque a penhora visa à expropriação de bens para satisfação integral do crédito exeqüendo. 2. Em hipóteses como a dos presentes autos, a jurisprudência do Superior Tribunal de Justiça
} 
Verifica-se, na jurisprudência, outrossim, uma nítida queda no número de decisões judiciais sobre a penhora de cotas sociais de empresas. Embora não se possa afirmar se tal queda decorre da pacificação da discussão sobre a penhorabilidade de tais quotas, cuja possibilidade com mais força se passou a reconhecer a partir de meados de 1980, ou se decorre de uma menor utilização do instituto, o fato é que a penhora de quotas sociais de sociedade limitada, a forma societária mais usual de organização da atividade empresarial no Brasil, pode ser instrumento bastante eficaz na satisfação de execuções. Nessa mesma linha, dado o intenso desenvolvimento do mercado de capitais brasileiro nos últimos anos, as ações e outros títulos de valores mobiliários podem ser alternativas bastante interessantes para penhoras eficazes.

Por fim, não se pode deixar de falar, pela sua importância, da penhora de imóveis, a qual, ainda, nos oferece um contraponto didático às outras modalidades de penhora antes mencionadas, todas de bens móveis, que assumem em grande parte forma incorpórea (ou imaterial). Esta, aliás, parece ser uma tendência irreversível no desenvolvimento das sociedades e economias modernas. A riqueza, a começar pelo dinheiro, como resultado da evolução tecnológica, está se desmaterializando e circulando na economia por formas cada vez mais complexas e dinâmicas. O futuro parece indicar que os atos de penhora tendem a, cada vez mais, incidir sobre bens incorpóreos. Trata-se indiscutivelmente de um desafio para os operadores do direito e os Processualistas em particular, já que o regime da penhora do nosso Código de Processo Civil é claramente baseado na penhora de bens corpóreos e muito pouco adaptado à consecução da penhora de bens incorpóreos. A Lei n. 11.382/2006 representou alguns avanços pontuais nesta matéria, mas há uma clara necessidade de uma mudança na estrutura do regime da penhora do Código de Processo Civil, a qual, sem exageros, não é muito diferente do regime do Código de Processo Civil de 1939. Para o operador do direito, como sistema-base da penhora de bens incorpóreos, restou o rito da

consolidou-se no sentido de que, não observada a ordem disposta no art. 11 da Lei n. 6.830/80, é permitida, ao credor e ao julgador, a inadmissão da nomeação à penhora, pois a execução é realizada em favor do exequiente, e não do executado[...]”. (DJ 07/08/2008, acessível na íntegra no http://www.stj.gov.br). 
"penhora de créditos e outros direitos patrimoniais", pouco adaptado às complexas formas de circulação dos bens imateriais na economia atual.

Nesse sentido, o procedimento previsto no Código de Processo Civil para a "penhora de créditos e outros direitos patrimoniais" (CPC, arts. 671 a 676) foi nitidamente moldado para regular a penhora de direitos inseridos no regime jurídico do Direito Obrigacional e dos Títulos de Crédito em sua configuração clássica, sem contemplar as especificidades das novas realidades, dos regimes jurídicos de direito bancário, de mercado de capitais, de direito público, etc.. ${ }^{225}$

Nossa intenção singela é contribuir com este debate a partir da análise da penhora dos seguintes bens móveis, pelo critério da maior liquidez, (a) dinheiro, (b) aplicação em instituição financeira, (c) valores mobiliários com cotação em mercado, (d), títulos da dívida pública com cotação em mercado, (e) créditos e (g) ações e quotas sociais de sociedade empresárias. Após, analisaremos a penhora de bem imóvel e deixaremos para o final as modalidades excepcionais de penhora de percentual do faturamento de empresa e de estabelecimento empresarial. O objetivo da análise desses tipos de penhora é oferecer modelos simplificados da realidade que sirvam de instrumento para que o operador do direito possa resolver com mais facilidade seus problemas concretos. ${ }^{226}$ Entremeada em nossa análise, criticaremos a ordem estabelecida no rol do artigo 655 do Código de Processo Civil, a qual não é coerente com a lógica do sistema de sempre preferir a penhora do bem mais líquido,

\footnotetext{
225 José Roberto dos Santos Bedaque, ainda antes do advento da Lei n. 11.382/2006, bem observava a desatualização do regime executivo em face da realidade econômica atual: "Ainda em sede do processo de execução, nota-se a enorme distância entre as regras do Código de Processo Civil e a realidade da vida, onde os grandes negócios são realizados por via bancária, dificultando sobremaneira a efetivação de um ato de constrição judicial. É preciso que o sistema processual se atualize, tendo em vista a evolução das relações econômicas verificadas nos últimos anos" (cf. Direito e processo p. 126).

${ }^{226}$ Flávio Luiz Yarshell trata de maneira bastante aprofundada das diversas funções do tipo na ciência jurídica. Neste capítulo a classificação em tipos tem por alvo “...oferecer uma série de modelos jurídicos idôneos à realização de interesses, segundo as necessidades surgidas do próprio convívio social. Essa função, em certo sentido, liga-se ao caráter concreto do tipo (em relação ao conceito), qual seja, o de descrever para permitir, com maior amplitude e menos rigidez, que uma realidade gere determinadas conseqüências ou que esteja sujeita a certa disciplina. Por outras palavras, o tipo pode servir à passagem do abstrato para o concreto, prestando-se a tipificação a uma especificação do conceito. Assim, em vez de restringir, o tipo acaba realizando a função de singularizar ou especializar" (cf. Tutela jurisdicional, p.47).
} 
embora, sensatamente, a jurisprudência tenha amenizado este problema ao não considerar absoluta e inflexível a ordem de penhora do referido dispositivo legal. ${ }^{227}$

Como metodologia, partiremos da descrição do objeto da penhora para estudar após o modo de apreensão e os efeitos na esfera material de cada um desses tipos de penhora. A premissa é a mesma na qual nos pautamos ao longo de todo esse trabalho, qual seja, a natureza do instituto da penhora, de se fazer atuar na realidade, nos leva necessariamente à intersecção do sistema processual com aquela realidade. Sob este enfoque não é possível propor soluções para uma penhora mais eficaz, sem considerações pertinentes ao seu objeto de incidência.

\subsection{Penhora de dinheiro}

\subsubsection{O dinheiro}

Antes de procuramos conceituar o "dinheiro", é preciso tratar, ainda que brevemente, do conceito de moeda.

A moeda é fenômeno complexo, pois é dotada de funções econômicas diversas, tais como (a) ser unidade de conta ou medida de valor de todos os bens e serviços de uma dada economia, (b) servir como intermediária de trocas de bens e serviços e

\footnotetext{
${ }^{227}$ Conforme análise baseada na jurisprudência do Superior Tribunal de Justiça feita por Humberto Theodoro Júnior, com expressa citação do acórdão proferido no RESP 167.158, publicado em 9 de agosto de 1999, de relatoria do Ministro Sálvio de Figueiredo Teixeira:"A jurisprudência, mesmo antes da reforma da Lei n. 11.382/2006, já entendia que a ordem do art. 655 não era absoluta e inflexível. O texto renovado do art. 655 afina-se com a jurisprudência ao estatuir que 'a penhora observará, preferencialmente" a gradação da lei (e não obrigatória ou necessariamente). Admite-se, de tal sorte, a justificação da escolha dentro dos parâmetros (i) da facilidade da execução e sua rapidez, e (ii) conciliação quanto possível, dos interesses de ambas as partes. Segundo a posição do Superior Tribunal de Justiça, ora prestigiada pelo texto do art. 655, caput, " a gradação legal há de ter em conta, de um lado, o objetivo de satisfação do crédito e, de outro, a forma menos onerosa para o devedor. A conciliação desses dois princípios é que deve nortear a interpretação da lei processual, especificamente os arts. 655, 656 e 620 do CPC'. Não há mais a regra rigorosa que outrora declarava ineficaz a nomeação fora da ordem legal (art. 656), de maneira que dúvida não há de se ter que o direito de escolher o bem a penhorar dentro da gradação do Código não é absoluto, mas relativo." (cf. Processo de execução e cumprimento de sentença, p. 271).
} 
(c) ser reserva de valor ou riqueza líquida, passível de conversão imediata em outros bens e serviços.

A moeda é capaz de exercer todas essas funções, pois os membros de uma dada comunidade a reconhecem como padrão de valor confiável dos bens e serviços produzidos naquele ambiente, sendo por isso mesmo capaz de suportar quaisquer transações de conteúdo econômico naquela comunidade. Nesse sentido, a moeda é instituição social que possibilita as relações de trocas da economia de mercado.

Para tanto, a moeda se exterioriza nos meios ou instrumentos de pagamentos que podem ser tangíveis, tal como é o papel-moeda, ou intangíveis, tal como é a moeda escritural, representada por lançamentos escriturais em contas bancárias, e a chamada moeda eletrônica que circula na economia por sistemas bancários informatizados, suportados em senhas, comandos eletrônicos, cartões de débito, etc..

Dito isso, do ponto de vista econômico, é possível vislumbrar a moeda sob dois estratos, um abstrato, o da moeda propriamente dita caracterizada por ser medida de valor ou de conta da economia, e o outro concreto, o equivalente aos meios ou instrumentos de pagamento, que é a forma sob a qual a moeda se exterioriza na atividade econômica.

Sob o ponto de vista jurídico, o papel do Estado é atribuir um nome legal à moeda como unidade abstrata de valor, sendo-lhe impossível estabelecer o valor intrínseco da moeda, o que irá emergir da interação entre os agentes econômicos nas suas relações de trocas de bens e serviços da economia. Cabe ao Estado também criar os meios ou instrumentos de pagamento, especialmente via emissão de papel-moeda, ou reconhecer sua criação por particulares, sob sua supervisão, garantindo a tais instrumentos curso legal e conseqüente poder liberatório de obrigações.

Os Bancos são os particulares que podem criar moeda, a partir da escrituração contábil de sua atividade de intermediação bancária de captação de recursos à 
vista e realização de empréstimos a terceiros, tudo sob a supervisão do Estado. Trata-se da moeda escritural, representada pelos depósitos à vista em instituições financeiras, que circula na economia via operações bancárias com a mesma capacidade liberatória do papel-moeda.

O dinheiro é o nome que se dá à moeda como instrumento de pagamento, seja na forma de papel-moeda ou na forma de moeda escritural, depositada em contas bancárias. Sob o enfoque jurídico, o dinheiro é espécie de bem móvel que serve de meio de pagamento de obrigações contraídas pelos agentes econômicos e também como reserva de valor. $^{228}$

Por ser o meio de pagamento de curso legal da economia, o dinheiro é o bem buscado pelo credor ao ajuizar a execução forçada. Com o dinheiro, satisfaz-se o cumprimento da obrigação de pagar. Sendo assim, o Legislador coloca o dinheiro como o bem preferencialmente penhorável (CPC, art. 655, I), não sendo necessária para satisfação do credor nenhuma providência adicional, senão sua transferência ao credor/exeqüente no momento processual oportuno.

Neste capítulo trataremos da penhora de dinheiro objeto do artigo 655, inciso I, do Código de Processo Civil. Deixaremos para abordar a penhora de "aplicação em instituição financeira”, também mencionada em referido dispositivo legal, no capítulo subseqüente.

\subsubsection{Modo de apreensão}

O dinheiro na economia atual se manifesta, em grande parte, na forma escritural. O dinheiro trafega pela economia por intermédio das instituições financeiras que operacionalizam a maior parte dos negócios de significação econômica de nossa sociedade: cobranças de faturas, pagamentos de salários, empréstimos, compra e venda de bens e serviços, investimentos, etc. Dessa forma, o dinheiro usualmente circula de conta

\footnotetext{
${ }^{228}$ Todo este trecho sobre a conceituação da moeda e do dinheiro foi baseado nas obras de José Simões Patrício (cf. Regime Jurídico do Euro, p. 321-367), Marcos Cavalcante de Oliveira (cf. Moeda, Juros e Instituições Financeiras, p. 123-200) e Sidnei Turczyn (cf. O Sistema Financeiro Nacional e a Regulação Bancária, 55-56).
} 
corrente à conta corrente dos agentes econômicos, via cheque, transferências eletrônicas, cartões de débito e crédito, etc. Por isso, cada vez mais o dinheiro não se materializa em papelmoeda, adquirindo uma forma eletrônica e intangível.

Como constata Marcos Cavalcante de Oliveira a partir da análise dos dados da moeda e dos chamados agregados monetários em circulação no Brasil: “ [...] a moeda é hoje um bem encontrado predominantemente nas instituições financeiras, pois são elas as depositárias dos depósitos à vista e de poupança, são elas as credoras ou devedoras das operações compromissadas com títulos federais, são elas as emissoras da maior parte dos títulos privados e são elas que administram os fundos de renda fixa". 229230

Sendo assim, já de algum tempo, tratar de penhora de dinheiro é tratar da penhora do dinheiro escritural depositado em conta corrente bancária de titularidade do Executado. É evidente que a Lei prevê, e pode ainda ocorrer alguns casos esporádicos de penhora do dinheiro em espécie, pela apreensão física operada pelo Oficial de Justiça, mas isto não é o usual ou o padrão e tende a ser cada vez mais rarefeito no ambiente social e econômico em que atualmente vivemos.

Por isso, concentraremos nossa análise na penhora de dinheiro depositado em conta corrente bancária.

O instrumento para realização desta penhora é o sistema informatizado criado pelo Banco Central do Brasil, já bem conhecido por seu nome pelos

\footnotetext{
${ }^{229}$ cf. Moeda, juros e instituições financeiras, p. 149.

${ }^{230}$ Trata-se de fenômeno evidentemente mundial, reflexo da atual fase do capitalismo, chamado financeiro. Um pouco antes do "Euro" passar a ser a moeda européia, José Simões Patrício em obra sobre o tema observava: “ Esta é uma simples mais incontornável realidade quotidiana, que o Direito não pode ignorar. Os pagamentos - o adimplemento dos compromissos pecuniários de cada um de nós - fazem-se através da entrega de signos monetários emitidos ou cunhados pelo Estado, sem dúvida, mas ainda muito mais (quantitativamente) por recurso à moeda escritural, seja através do saque de cheques (como entre nós e noutros países se verifica largamente), seja mediante transferências de conta a conta, domésticas ou internacionais (em Portugal menos utilizadas, decerto, por virtude das elevadas comissões bancárias ainda praticadas). Além destes já clássicos instrumentos de circulação da moeda escritural, poderia falar-se dos de carácter eletrônico: cartões de crédito e débito, assim como a geração mais recente dos porta moedas electrónicos. Porém, com as especificidades que lhe são próprias - e que advém da própria tecnologia e/ou da complexidade das relações jurídicas estabelecidas - será porventura legítimo afirmar que não diferem em última análise dos anteriormente indicados processos de fazer circular a moeda escritural". (cf. Regime jurídico do euro, p. 359).
} 
operadores do direito, o sistema BACEN-JUD. A criação deste sistema foi sem dúvida nenhuma iniciativa importante para o bom funcionamento da execução forçada. Sua eficácia é evidente. Segundo informações estatísticas prestadas pelo Banco Central em sua página na internet, no ano de 2008, até o mês de novembro, só a Justiça Estadual de São Paulo expediu 701.907 ordens via o sistema Bacen-Jud, o que inclui ordens de requisição de informações financeiras, bloqueio de valores, desbloqueio de valores e transferência de valores para conta judicial. Seguindo ainda na análise dos dados estatísticos fornecidos pelo Banco Central, no ano de 2000, o ano imediatamente anterior à implantação do sistema que funcionou inicialmente na Justiça do Trabalho, o Banco Central havia recebido via ofício em papel 71.461 ordens ou requisições de todos os órgãos do Poder Judiciário. No ano de 2008, só de ordens judiciais via o sistema Bacen-Jud 2.0 foram recebidas 3.328.899. E mais, o que antes era uma ferramenta restrita à Justiça do Trabalho hoje se espraia por todos os órgãos do Poder Judiciário, especialmente à Justiça Estadual. No ano em que os órgãos da Justiça Estadual passaram a usar o sistema, em 2005, as ordens geradas pela Justiça do Trabalho representavam 98\% do total. No ano de 2006, a Justiça do Trabalho tinha $74 \%$ do total de ordens e a Justiça Estadual 24\%. Em 2008, já é igual a proporção de ordens, sendo 47\% partidas da Justiça do Trabalho e $47 \%$ da Justiça Federal. A Justiça Federal tem os $6 \%$ restantes. $^{231}$

Embora tais estatísticas não nos informem a porcentagem de ordens judiciais que alcançaram seu intento, tampouco quantas dessas ordens resultaram em execuções satisfeitas, os números nos permitem concluir que o sistema tem sido uma ferramenta cada vez mais importante à disposição do Poder Judiciário para dar efetividade à execução forçada.

Nesse universo, é certo que abusos ou erros são cometidos, especialmente o conhecido problema do bloqueio de um mesmo montante em contas múltiplas, ${ }^{232}$ os quais devem ser permanentemente coibidos e rapidamente reparados, mas tais desvios não podem manchar a inequívoca utilidade de ferramenta devidamente adaptada à

\footnotetext{
${ }^{231}$ Estas informações estão disponíveis na página na internet do Banco Central do Brasil: http://www.bcb.gov.br.

${ }^{232}$ Nesse sentido trata-se de medida bastante interessante a criação pelo Conselho Nacional de Justiça, pela Resolução n. 61 de 7 de outubro de 2008, de um sistema de cadastros de contas únicas, cujos interessados podem cadastrar uma única conta no sistema BACEN-JUD para efeito de eventual penhora, desde que se comprometam a manter recursos suficientes a suportar eventuais constrições judiciais.
} 
realidade econômica e social atual, como contribuição necessária a uma execução forçada mais efetiva.

Tanto é assim que o Legislador, por intermédio da Lei $\mathrm{n}$. 11.382/2006 pôs fim a qualquer discussão sobre a legalidade da utilização do sistema, introduzindo no Código de Processo Civil o art. 655-A que tem a seguinte disposição: "para possibilitar a penhora de dinheiro em depósito ou aplicação financeira, o juiz, a requerimento do exeqüente, requisitará à autoridade supervisora do sistema bancário, preferencialmente por meio eletrônico, informações sobre a existência de ativos em nome do executado, podendo no mesmo ato determinar sua indisponibilidade, até o valor indicado na execução".

A apreensão de dinheiro pelo sistema BACEN-JUD se inicia por intermédio de ordem judicial transmitida eletronicamente pelo Juiz da execução ao Banco Central do Brasil para bloqueio de quantia disponível em conta corrente bancária de titularidade do executado em instituição financeira da qual ele seja cliente. No mesmo dia em que o Banco Central recebe a ordem judicial, esta é validada e transmitida eletronicamente às instituições financeiras. No dia seguinte, se a instituição financeira identificar a existência de numerário em conta corrente pertencente ao executado, há o bloqueio do numerário no valor constante da ordem judicial. A instituição financeira que procedeu ao bloqueio presta esta informação no dia seguinte ao Banco Central. No dia subseqüente, o Banco Central, sempre via o sistema, informa ao Juiz que o valor foi bloqueado. Recebida esta informação pelo Juiz, cabe a ele emitir também via sistema uma outra ordem, desta vez de transferência do numerário bloqueado em conta corrente bancária para a instituição financeira depositária dos valores, cujos dados devem ser indicados pelo Juiz.

Cabe notar não haver bloqueio da movimentação da conta corrente bancária pelo executado, o que seria evidentemente abusivo e extrapolaria a finalidade do ato de penhora. Deve haver sim o bloqueio de dinheiro disponível do executado em conta bancária, até o limite do valor constante da ordem judicial. Conforme consta do regulamento do sistema disponível na página da internet do Banco Central, ${ }^{233}$ cumprida a ordem judicial

\footnotetext{
${ }^{233} \mathrm{O}$ regulamento do sistema é acessível no endereço eletrônico http://www.bcb.gov.br.
} 
pela instituição financeira, ainda que o valor bloqueado não tenha sido suficiente para atender plenamente à ordem, não pode a instituição financeira vir a bloquear valores posteriormente depositados naquela conta corrente, a qual pode continuar a ser movimentada normalmente pelo executado. Isto não impede que o Juiz dê novas ordens de bloqueio na forma de "reiterações" daquela primeira ordem, tal como consta do sistema.

Feito o bloqueio do dinheiro em conta bancária e transferido o montante à instituição financeira de confiança do Juízo, deverá ser formalizada a penhora por termo nos autos a ser lavrado pelo escrivão do Juízo tão logo detenha todas as informações pertinentes à apreensão e ao depósito, especialmente a data da transferência do numerário à conta judicial e o exato valor transferido. ${ }^{234}$

\subsubsection{Efeitos}

O dinheiro depositado em conta corrente bancária é bem móvel, incorpóreo e fungível, passível de depósito em instituição financeira.

Por ser bem incorpóreo, de fácil e rápida movimentação, a apreensão do dinheiro depositado em conta bancária se dá por determinação judicial de indisponibilidade da quantia na conta bancária do executado. De natureza escritural, o dinheiro é passível de depósito (guarda e custódia) na instituição financeira de confiança do juízo da execução (CPC, art. 666, I).

O executado perde os poderes de dispor e de gozar o bem.

\footnotetext{
${ }^{234}$ Nos termos do que ensina Humberto Theodoro Júnior: "De posse da informação sobre o bloqueio, o escrivão providenciará a lavratura do termo de penhora, procedendo-se, em seguida, à intimação do executado, pelo oficial de justiça, na forma do art. 652, parágrafo $1^{\circ}$. Se o devedor tiver procurador nos autos, a intimação será realizada em sua pessoa. Caso contrário, será feita pessoalmente ao executado (art. 652, parágrafo $4^{\mathrm{o}}$.)”. (cf. Processo de execução e cumprimento da sentença, p. 282)
} 


\subsection{Penhora de aplicação em instituição financeira}

\subsubsection{A aplicação em instituição financeira}

O artigo 655, inciso I, do Código de Processo Civil, determina que, ao lado do dinheiro, a "aplicação em instituição financeira" deva ser preferencialmente penhorada.

O termo, normalmente utilizado apenas como "aplicação financeira" ou "investimento financeiro", não é jurídico, mas do campo da economia e finanças. Não qualifica juridicamente um tipo ou uma espécie de bem em circulação na economia, mas designa o ato, na definição do dicionário Houaiss, de "emprego de capital e/ou títulos em condições de produzir juros ou conservar seu poder aquisitivo; investimento". ${ }^{235}$

Trata-se de investimento de dinheiro em ativos ou produtos disponíveis no mercado financeiro que proporcionem o recebimento de juros. Tais ativos ou produtos são oferecidos pelas instituições financeiras e podem assumir uma série de formas jurídicas: títulos, cotas de fundos de investimento, créditos, etc.. Por isso, o termo "aplicação em instituição financeira" pode se referir a diferentes tipos de bens com os mais variados regimes jurídicos. ${ }^{236}$ Quanto ao seu conteúdo, podem apresentar diferentes níveis de risco,

\footnotetext{
235 cf. Dicionário Houaiss da Língua Portuguesa, p. 254.

${ }^{236}$ Tal como anota Marcos Cavalcante de Oliveira: “É muito importante notar que os mercados financeiros são o próprio encontro entre aquelas pessoas que estão dispostas a ser provedoras de recursos oriundos de suas poupanças e aquelas outras que estão necessitadas de fundos para realizar seus investimentos. Nesse encontro, as unidades provedoras de fundos cedem seu dinheiro recebendo em troca apenas promessas, as quais são como que 'embaladas' na forma de direitos e serviços financeiros, tais como ações, depósitos a prazo e à vista, apólices de seguro, contratos de empréstimo e outros. Esses instrumentos financeiros prometem ao provedor de fundos um fluxo de receita futura na forma de dividendo, juros, tarifas, aluguéis ou indenizações de seguros. $O$ provedor de fundo só os cede para o outro fazer seus investimentos porque espera receber de volta o principal emprestado e mais uma remuneração por ter aguardado que o investidor usasse os fundos pelo tempo contratado". (cf. Moeda, juros e instituições financeiras, p. 22).
} 
prazos de vencimento e graus de liquidez, a depender do produto e da contratação ajustada com a instituição financeira.

Assim, a abrangência e generalidade do termo "aplicação em instituição financeira" não permite identificar com precisão a quais ativos financeiros o Legislador pretendeu se referir. É possível que a referência tenha sido feita aos ativos ou bens financeiros com alto grau de liquidez. ${ }^{237}$

Por outro lado, os ativos financeiros são, em regra, mais facilmente transformáveis em dinheiro do que a maioria dos outros bens arrolados no artigo 655 do Código de Processo Civil, o que respaldaria o entendimento pelo qual quaisquer ativos ou bens financeiros, independentemente do seu grau de liquidez, são preferíveis a outras espécies de bens não financeiros. ${ }^{238}$

O artigo 655-A do Código de Processo Civil determina a consulta à autoridade supervisora do sistema bancária, por meio eletrônico, para obtenção de informações "sobre a existência de ativos em nome do executado" e também para decretação de sua indisponibilidade.

O Convênio de Cooperação Técnico-Institucional ${ }^{239}$ celebrado em 30 de setembro de 2005, entre o Banco Central do Brasil, o Superior Tribunal de Justiça e o Conselho da Justiça Federal "para fins de operacionalização do sistema Bacen-Jud 2.0”, ao qual os Tribunais Regionais Federais e os Tribunais de Justiça dos Estados devem aderir para utilizar o sistema, deixa claro sua destinação para o encaminhamento às instituições

\footnotetext{
${ }^{237}$ Segundo Marcos Cavalcante de Oliveira o Legislador no art. 655, inciso I, do Código de Processo Civil está se referindo à moeda e aos agregados monetários que tem alta liquidez e podem ser considerados meios de pagamento ampliados, tais como cotas de fundo de renda fixa, carteiras de títulos registradas no Sistema Especial de Liquidação e Custódia (SELIC) e títulos públicos de alta liquidez. (cf. Moeda, juros e instituições financeiras, p. 146/147)

${ }^{238}$ No mesmo patamar dos ativos financeiros, em termos de rápida liquidação, poderiam ser colocadas ações cotadas em Bolsa (CPC, art. 655, VI), títulos da dívida pública com cotação em mercado (CPC, art. 655, IX) e títulos e valores mobiliários com cotação em mercado (CPC, art. art. 655, X). Aliás, cabe registrar não ser compreensível a opção feita pelo Legislador na recente reforma de colocar tais bens, na ordem de preferência, abaixo de outros bens, notoriamente de mais difícil e bem mais complexa liquidação, tais como veículos, bens móveis, bens imóveis, navios e aeronaves, etc..

${ }^{239}$ Este Convênio está acessível na página da internet no Banco Central do Brasil: http://www.bcb.gov.br.
} 
financeiras de "ordens judiciais de bloqueio, desbloqueio e transferência de valores existentes em contas de depósitos à vista (contas correntes), de investimento e de poupança, depósitos a prazo, aplicações financeiras e outros ativos passíveis de bloqueio, de pessoas físicas e jurídicas, bem como outras ordens judiciais, nos termos do Regulamento anexo." (cláusula primeira, $\S 1^{\mathrm{o}}$.).

O regulamento do sistema, na leitura conjugada de seus artigos $8^{\circ}$. e 17 , no que se refere às aplicações financeiras, estabelece como passíveis de bloqueio os saldos existentes em poupança, fundos de investimento sob administração e depósitos a prazo (CDB/RDB), bem como "todos os ativos sob administração e/ou custódia da instituição financeira".

Quer dizer, pela análise das normas operacionais de funcionamento do sistema BACEN-JUD, a ordem judicial de bloqueio de valores, leia-se dinheiro ou "aplicação em instituição financeira" (CPC, art. 655, I), deve atingir, além do dinheiro em conta corrente, saldos de poupança, cotas de fundo de investimento, depósitos a prazo (CDB/RDB) e quaisquer outros ativos de titularidade do executado sob administração e/ou custódia da instituição financeira. É um rol de bens amplo. Não se trata de disposição legal, mas suas repercussões práticas são importantes.

Como não seríamos capazes de abarcar todas as espécies de ativos financeiros disponíveis no mercado e de suas repercussões no ato de penhora, tomaremos como referência de nossa análise a penhora de "poupança", do "certificado de depósito bancário" (CBD) e das "cotas de fundo de investimento".

\subsubsection{Modo de apreensão}

Como já dissemos, nos termos do art. 655-A do Código de Processo Civil, o sistema BACEN-JUD é hoje a ferramenta disponibilizada pelo Banco Central do Brasil para operacionalizar a penhora de "aplicação em instituição financeira". 
O sistema prevê para tal tipo de penhora exatamente o mesmo procedimento aplicável à penhora de dinheiro em conta corrente.

Em verdade, a ordem de bloqueio expedida pelo Juiz via sistema, a não ser que o Juiz indique uma conta ou aplicação financeira específica, visa a atingir indistintamente dinheiro em conta ou ativos financeiros detidos pelo executado em instituições financeiras do qual seja cliente.

Tanto para dinheiro como para ativos financeiros, as regras do sistema BACEN-JUD são as mesmas; primeiro bloqueia-se o valor constante da ordem judicial, tornando-o indisponível para o Executado, e depois, por uma outra ordem judicial, determina-se sua transferência a uma conta judicial.

Ocorre que o ativo financeiro não é dinheiro. Por maior que seja sua liquidez, a conversão financeira do ativo financeiro depende de uma ordem de resgate dada pelo seu titular à instituição financeira, dentro das regras contratadas, para que o ativo seja liquidado e o dinheiro fique disponível, momento em que os juros sobre a aplicação deixam de incidir.

Apesar disto, segundo o regulamento do sistema Bacen-Jud, bloqueado o ativo e recebida a ordem de transferência do valor financeiro, a instituição financeira procederá à liquidação do ativo, sem se aguardar os "prazos dos contratos da aplicação financeira e o 'aniversário' das contas de poupança”. ${ }^{240}$

Nos casos em que as regras do investimento não permitirem o resgate antecipado por seu titular, está fora de dúvida não poder o Juiz determinar ao Banco que antecipe o cumprimento de sua obrigação, liquidando a aplicação. Tal seria o mesmo que determinar ao devedor de nota promissória emitida em favor do executado que antecipasse o cumprimento da obrigação, depositando em juízo a quantia devida, para que a penhora não incidisse sobre a nota promissória, mas sobre o dinheiro. Se o investimento possibilitar o

\footnotetext{
${ }^{240}$ Trata-se do art. 10, parágrafo $4^{\circ}$., do regulamento do sistema BACEN-JUD.
} 
resgate antecipado, ainda que se vislumbre no Juiz penhorante o poder de determinação da liquidação do ativo, como efeito decorrente da perda pelo executado de seus poderes de dispor e de gozar o bem, ${ }^{241}$ deve-se analisar a característica específica do ativo financeiro e as peculiaridades do caso concreto para evitar-se extrapolação indevida do ato de penhora, bem como oneração excessiva do executado.

Isto porque usualmente a remuneração do ativo financeiro é superior à remuneração da conta judicial. Pegue-se um CDB ou uma cota de fundo de investimento em renda fixa e certamente se obterá uma remuneração mais vantajosa do que aquela proporcionada pela conta judicial. Além disso, há ativos com prazo certo de vencimento cuja liquidação antecipada implica na perda da remuneração ajustada, sem se falar no impacto tributário que uma medida deste tipo pode causar, criando ônus e penalizações indevidas ao executado. $^{242}$

Para a penhora do ativo financeiro, cabe ao Juiz utilizar o sistema BACEN-JUD para bloquear o ativo. Caso o ativo tenha prazo de vencimento determinado, deve-se aguardar o prazo de vencimento para se ordenar a transferência do montante resultante para a conta judicial, momento em que a penhora passa a incidir sobre o dinheiro.

Trata-se de procedimento que respeita a integridade do bem penhorado, além de ser vantajoso tanto ao exeqüente como ao executado, já que o ativo financeiro continuará a se valorizar, nos termos do contrato, até o momento processual próprio de determinação pelo Juiz de sua liquidação definitiva e posterior transferência do montante final ao exeqüente e satisfação da execução. Se por qualquer motivo a penhora vier a ser desconstituída, o Juiz simplesmente ordena o desbloqueio do ativo financeiro em favor do executado.

\footnotetext{
${ }^{241}$ Na Doutrina Portuguesa, segundo Fernando Amâncio Ferreira, citando Remédio Marques na nota de rodapé 521, "os depósitos a prazo podem ser mobilizados antecipadamente pelo agente de execução, em substituição do executado, se tal possibilidade se encontrar prevista no contrato de abertura de conta, embora tal procedimento envolva perda de juros ou de outras contrapartidas". (cf. Curso de processo de execução, p. 258).

${ }^{242} \mathrm{O}$ art. 10, parágrafo $7^{\circ}$, do Regulamento do sistema determina que "os tributos decorrentes do cumprimento da ordem de transferência serão suportados pelo réu/executado. Na insuficiência de recursos disponíveis, o valor dos tributos será deduzido da quantia a ser transferida. As instituições financeiras não poderão deduzir tarifas bancárias do valor a ser transferido".
} 
Esta análise, evidentemente, pode variar a depender das circunstâncias do caso concreto, especialmente pela modalidade do ativo financeiro bloqueado. No caso de bloqueio de conta poupança, pela usual equivalência de sua remuneração com aquela paga pela conta judicial, a transferência para uma conta judicial funcionaria como uma ordem do Juiz de migração do ativo financeiro bloqueado para outro da mesma espécie. Caso se trate de uma execução fiscal de tributos federais a transferência para a conta judicial pode ser a melhor solução, uma vez que tais depósitos são corrigidos pela variação da SELIC, ${ }^{243}$ o mesmo fator de correção dos tributos, evitando-se assim discrepâncias futuras.

A análise da penhora de conta-poupança, de certificado de depósito bancário e de cota de fundo de investimento pode ajudar na compreensão do problema.

A conta-poupança é espécie de depósito remunerado pela instituição financeira, conforme taxa de juros pré-estabelecida, "a prazo fixo". Mensalmente, na data de "aniversário", o titular auferirá rendimento. Se o resgate do investimento ocorrer antes do prazo ocorre perda da remuneração daquele mês. ${ }^{244}$

Com grau de liquidez altíssimo, de quase-moeda, e considerando terem as contas judiciais normalmente remuneração equivalente à poupança e nos casos de débitos tributários terem remuneração ainda superior, pela SELIC, não vemos óbice à atuação do Juiz, na penhora de poupança, de primeiro bloquear o ativo via sistema BACEN-JUD, e depois determinar a transferência do numerário a outro ativo do mesmo tipo, a conta judicial. Nesse caso, o Juiz determina a migração do ativo administrado por um Banco para ativo equivalente administrado por Banco da confiança do Juízo. De toda forma, é recomendável ao Juiz aguardar a próxima data de "aniversário" do investimento para determinar a transferência.

\footnotetext{
${ }^{243}$ Conforme Lei n. 9703/98 e Decreto n. 2850/98.

${ }^{244} \mathrm{Na}$ lição de Fábio Ulhoa Coelho "as cadernetas de poupança são produtos oferecidos pelos bancos que, sob o ponto de vista contratual, representam depósito bancário a prazo fixo. A definição do prazo mínimo para resgate pode ser condição da remuneração, como nas Cadernetas de Poupança, ou do próprio negócio. Assim, no primeiro caso, o depositante que pretender a restituição dos recursos antes do prazo perde a remuneração; no segundo, o depositante sequer pode solicitá-la antes do prazo fixado". (cf. Manual de direito comercial, p. 449/450).
} 
Seria ainda melhor alterar o sistema BACEN-JUD, de modo que as instituições financeiras só pudessem fazer transferência judicial do numerário após a data de "aniversário" do investimento.

O certificado de depósito bancário (CDB) é regulado no ordenamento jurídico brasileiro pelo art. 30 da Lei n. 4728/65, além de uma série de normas circulares do Banco Central do Brasil. Trata-se de modalidade de investimento que pode ter diversos tipos de ajustes, com pagamento de amortizações periódicas, pagamento em parcela única, taxas prefixadas, taxas flutuantes, previsão de resgate antecipado, etc. ${ }^{245}$ No essencial, "trata-se de título cambiariforme (promessa de pagamento literal e autônoma) emitido em série, conforme modelo oficial, que incorpora os direitos correspondentes a um contrato de depósito bancário a prazo fixo". ${ }^{246}$ É título de crédito resultante de depósito a prazo fixo feito em instituição financeira. Hoje, as instituições financeiras emitem o CDB na forma escritural, e usualmente o custodiam na CETIP - Câmara de Custódia e Liquidação, ${ }^{247}$ entidade de mercado de balcão organizado. Intermediado por instituição financeira, o CDB pode ser livremente negociado por seu beneficiário, na CETIP, a terceiros.

O CDB é então um título de crédito escritural emitido por uma instituição financeira em benefício de seu cliente, cabendo à CETIP a custódia daquele título.

Sobre a penhora do CDB, há uma disposição específica no art. $30, \S$ terceiro, da Lei n. 4728/65, pela qual "emitido pelo Banco o certificado de depósito bancário, o crédito contra o Banco emissor, pelo principal e pelos juros, não poderá ser objeto de penhora, arresto, seqüestro, busca ou apreensão, ou qualquer outro embaraço que impeça o

\footnotetext{
245 Conforme informações constantes do Caderno sobre regras de legislação-levantamento dos ativos registrados na CETIP, relatório produzido pela CETIP e disponível em seu site: http://www.cetip.com.br.

246 cf. Sergio Carlos Covello (Contratos Bancários, p. 85).

${ }^{247}$ Sobre a atuação da CETIP, entidade fundada pelos Bancos, mas com atuação deles independente: "Ela atua principalmente como uma empresa de custódia e liquidação financeira, caracterizando-se como um mercado de balcão organizado para registro e negociação de títulos e valores mobiliários de renda fixa. A CETIP presta o serviço de processar e registrar, por meio de sistemas informatizados, o registro, a transferência e a liquidação financeira de títulos e valores mobiliários emitidos principalmente por instituições financeiras autorizadas a funcionar pelo Banco Central do Brasil. Note-se que tanto o SELIC quanto o CETIP só registram operações com títulos emitidos escrituralmente, ou seja, que não dispõem dos atributos clássicos da cartularidade, pois existem apenas sob a forma de registros eletrônicos ( os títulos físicos, quando emitidos em papel - o que é muito raro -, são materialmente custodiados por bancos autorizados)." (cf. Moeda, juros e instituições Financeiras, p. 207).
} 
pagamento da importância depositada e dos seus juros, mas o certificado de depósito poderá ser penhorado por obrigação do seu titular".

Ocorre que por ser documento escritural e intangível, como a maioria dos títulos de crédito em circulação na economia atual, a apreensão física do documento não é mais possível. Em razão disso, a apreensão do CDB só pode se dar pela intimação do agente custodiante, para que bloqueie a negociação do título a terceiros, bem como a intimação ao Banco para que não torne disponível ao executado a quantia consignada no título, o que está dentro das funcionalidades do sistema BACEN-JUD, e não constitui embaraço ao pagamento pelo Banco da quantia consignada no título na data de seu vencimento, a qual, contudo, ficará indisponível ao executado.

A intimação à CETIP, ou outra entidade custodiante, cumpre a finalidade do "caput" do art. 672 do Código de Processo Civil de impedir a negociação pelo executado do título escritural com terceiros. A ordem de indisponibilidade a ser cumprida pelo Banco atende às determinações do artigo 655-A do Código de Processo Civil e do artigo 671, inciso I, do Código de Processo Civil.

Após, o Juiz deve formalizar o auto de penhora, nomeando a CETIP como depositária do título escritural.

Ocorrendo o vencimento do título penhorado, o Banco faz a liquidação do título em conta do executado, numerário que permanecerá indisponível, nos termos do art. $10, \S 2^{\circ}$., do regulamento do Sistema BACEN-JUD, e neste momento o Juiz ordena a transferência do numerário à conta judicial, passando a penhora a incidir sobre o dinheiro.

Por último, o fundo de investimento. O investidor interessado em aplicar em um fundo de investimento deve comprar cotas representativas, usualmente escriturais, de seu patrimônio. A cota de fundo de investimento, nos termos da definição da Instrução CVM n. 409/04, corresponde à fração ideal de seu patrimônio. Isto quer dizer que as 
cotas detidas pelo cotista constituem representação proporcional do patrimônio detido pelo fundo, sendo certo que a rentabilidade das cotas deverá refletir a rentabilidade dos ativos financeiros componentes do patrimônio do fundo. Tais ativos podem ser de diversas naturezas, títulos do governo, ações, títulos privados, etc.,. Cabe ao administrador, normalmente uma instituição financeira, zelar pelo patrimônio do fundo e administrá-lo conforme as diretrizes de seu regulamento e prospecto.

Os fundos de investimento se organizam de diversas formas e vários fatores interferem na análise das características e atributos do fundo: pode se destinar a clientes institucionais ou ao mercado em geral, pode ser um fundo preponderantemente de ativos de baixo risco, pode ser um fundo que investe preponderantemente em ações, pode ser um fundo de gestão terceirizada, pode ser um fundo aberto ou um fundo fechado, etc.. ${ }^{248}$

Cada uma dessas variáveis pode interferir na análise da penhora de cotas de fundo de investimento. Considerando isto, restringiremos nossa análise à penhora de cota de fundo de investimento aberto, cujas cotas podem ser resgatadas a qualquer momento pelo investidor, mas as cotas não podem ser negociadas pelos cotistas para terceiros em Bolsa de Valores ou mercado de balcão. Este é o tipo de fundo usualmente oferecido pelos bancos a seus clientes como uma "aplicação financeira".

O procedimento é o padrão da penhora de ativos financeiros. Emitida pelo sistema BACEN-JUD a ordem judicial de bloqueio de bens do executado a instituição financeira-administradora do fundo de investimento, receptora da ordem, deve tornar indisponível para o executado as cotas de fundo de investimento do qual ele seja titular, impedindo a partir daquele momento seu resgate.

Após, o Juiz deve formalizar o auto de penhora, nomeando o administrador do fundo como depositário das cotas.

\footnotetext{
${ }^{248}$ As informações sobre o funcionamento dos fundos de investimentos foram baseadas nas obras de Eizirik, Gaal, Parente, et al. (Mercado de capitais - regime jurídico, p. 76-96) e de Ricardo de Santos Freitas (Natureza jurídica dos fundos de investimento, p. 93-109).
} 
Por fim, cabe concluir que se as circunstâncias do caso levarem à necessidade de liquidação antecipada do ativo financeiro o Juiz deve observar o rito do artigo 670 do Código de Processo Civil, com exceção das hipóteses em que o ativo financeiro bloqueado tenha remuneração igual ou menor daquela paga pela conta judicial. Nos demais casos, a liquidação antecipada só pode ocorrer em caso de risco de deterioração ou depreciação do bem (inciso I) ou manifesta vantagem (inciso II), com a oitiva prévia das partes, nos termos do que determina o parágrafo único do referido dispositivo legal.

\subsubsection{Efeitos}

Os ativos financeiros são, em regra, bens móveis e incorpóreos. Tomando-se como referência os bens analisados no item precedente, a conta-poupança se constitui em um "crédito" do executado em face da instituição financeira; o CDB da mesma forma se constitui em direito de crédito representado por título escritural, passível de custódia, e a cota do fundo de investimento é direito representativo de fração ideal em patrimônio constituído sob forma de condomínio. ${ }^{249}$

Por se constituírem em bens incorpóreos, de fácil e rápida movimentação, a apreensão ocorre por determinação judicial de indisponibilidade do ativo financeiro de titularidade do executado. Por assumirem, em regra, forma escritural, os ativos financeiros são passíveis de depósito (guarda e custódia) na própria instituição financeira ou em instituição custodiante do bem.

O executado perde os poderes de dispor e de gozar o bem.

\footnotetext{
${ }^{249}$ Op. cit. (Mercado de Capitais - Regime Jurídico, p. 78).
} 


\subsection{Penhora de títulos e valores mobiliários com cotação em mercado}

\subsubsection{Os valores mobiliários}

Segundo os especialistas na matéria, não é tarefa fácil conceituar valor mobiliário. Eizirik, Gaal, Parente, et al, partem do conceito de security do direito norteamericano para abordar a matéria no direito brasileiro. Segundo referidos Autores, "no direito norte-americano, constituem securities não somente os títulos tradicionalmente emitidos por uma sociedade anômima (como ações e debêntures), mas também qualquer 'contrato de investimento', considerando-se, como tal, via de regra, aquele correspondente a um investimento em dinheiro em um empreendimento comum, cujos lucros dependam, essencialmente, dos esforços de terceiros." ${ }^{250} \mathrm{Na}$ lei brasileira atual, em linha com a concepção de security do direito norte-americano, são considerados valores mobiliários os títulos expressamente previstos no art. $2^{\circ}$. da Lei n. 6.385/1976, quais sejam, (a) as ações, debêntures e bônus de subscrição; (b) os cupons, direitos, recibos de subscrição e certificados de desdobramentos relativos aos valores mobiliários referidos no item "a" anterior; (c) os certificados de depósito de valores mobiliários; (d) as cédulas de debêntures; (e) as cotas de fundos de investimento em valores mobiliários ou de clubes de investimentos em quaisquer ativos; (f) as notas comerciais; (g) os contratos futuros, de opções e outros derivativos, cujos ativos subjacentes sejam valores mobiliários, (h) outros contratos derivativos, independentemente dos ativos subjacentes, e também, (i) "quando ofertados publicamente, quaisquer outros títulos ou contratos de investimento coletivo, que gerem direito de participação, de parceria ou de remuneração, inclusive resultante de prestação de serviços, cujos rendimentos advêm do esforço do empreendedor ou de terceiros". ${ }^{251}$ Cabe registrar que a Lei n. 6.385/76, no art. $2^{\circ}$., $\S 1^{\circ}$., exclui do regime jurídico do mercado de valores mobiliários (a) os títulos da dívida pública federal, estadual ou municipal, e (b) os títulos cambiais de responsabilidade de instituição financeira, exceto as debêntures.

\footnotetext{
${ }^{250}$ op.cit., p. 32-33.

${ }^{251}$ Trata-se da redação do art. $2^{\circ}$., da Lei n. 6.385/76, inciso IX.
} 
Eizirik, Gaal, Parente, et al., procuram listar as características típicas dos valores mobiliários. Resumindo, (a) não possuem um valor intrínseco; o valor do ativo depende totalmente de fatores externos a ele, da economia, do mercado, do empreendimento, etc.; (b) são emitidos e ofertados publicamente a investidores que, em regra, podem negociá-los no mercado secundário; (c) os valores mobiliários têm características díspares entre si por atribuírem diferentes direitos e se destinarem a diferentes finalidades e (d) corporificam investimentos de risco, cujo retorno está atrelado ao sucesso do empreendimento, o que os difere dos instrumentos de concessão de crédito, "nos quais o detentor do título assume apenas o risco de crédito do devedor". 252

No art. 655 do Código de Processo Civil, o tratamento dos valores mobiliários é assistemático. $\mathrm{O}$ inciso $\mathrm{X}$ arrola os "títulos e valores mobiliários com cotação em mercado" como o penúltimo bem na ordem dos bens preferencialmente penhoráveis. O inciso VI trata das "ações", espécie de valor mobiliário. O inciso I trata da "aplicação em instituição financeira" que pode se constituir em valor mobiliário, tal como a cota de fundo de investimento.

A harmonização possível na ordenação de tais estipulações legais do artigo 655 é a seguinte: (a) o valor mobiliário se insere no inciso I nos casos em que for ofertado ao mercado, custodiado e administrado por instituição financeira; é o caso da cota de fundo de investimento aberto sobre a qual tratamos no capítulo 4.3.; (b) as "ações", cotadas ou não em mercado, estão na classe de preferência do inciso IV, (c) os valores mobiliários com cotação em mercado, excluindo-se as ações, devem ser classificados na classe de preferência do inciso X e (d) os demais valores mobiliários devem ser classificados no inciso XI como "outros direitos".

Faltou mais rigor ao legislador no estabelecimento do rol de preferências do art. 655 do Código de Processo Civil. Atendendo ao critério de bens com significação econômica de mais fácil liquidação em dinheiro, deveria o Legislador ter definido

252 op. cit., p. 23-24. 
os "títulos e valores mobiliários com cotação em mercado", o que já incluiria as ações, como o segundo bem na ordem de preferência para penhora, atrás apenas do dinheiro e da "aplicação em instituição financeira". No atual estágio de desenvolvimento da economia brasileira e de seu mercado de capitais, é incompreensível a opção feita pelo legislador.

Neste capítulo, trataremos especificamente dos valores mobiliários com cotação em mercado.

Sob o aspecto da interpretação da lei processual, o mais importante é identificar o que faz de um valor mobiliário um bem "com cotação em mercado", tal como disposto no artigo 655, inciso X, do Código de Processo Civil.

Os parâmetros para tal análise estão na Instrução CVM n. 461/2007. Esta instrução "disciplina o funcionamento dos mercados regulamentados de valores mobiliários". Dentre tais mercados regulamentados, há os mercados organizados de bolsa e de balcão e os mercados não organizados de balcão.

Nos termos da referida instrução, o mercado organizado, de bolsa ou de balcão, propicia "o espaço físico ou o sistema eletrônico, destinado à negociação ou ao registro de operações com valores mobiliários por um conjunto determinado de pessoas autorizadas a operar, que atuam por conta própria ou de terceiros" (art. $3^{\circ}$, caput). Os negócios com valores mobiliários realizados fora deste espaço físico ou sistema eletrônico, centralizado e passível de registro, consideram-se realizados em mercado de balcão não organizado.

Conforme Eizirik, Gaal, Parente, et al., "as bolsas e entidades de mercado de balcão organizado exercem esse papel de facilitar as negociações no mercado secundário, pois têm a função primordial de organizar, manter e fiscalizar um local ou sistema adequado e seguro para a realização de operações de compra e venda de valores mobiliários, dotando-os permanentemente, de todos os meios necessários à pronta e eficiente realização e visibilidade das operações". ${ }^{253}$ Ainda segundo referidos Autores, há por sua vez três diferenças

\footnotetext{
253 op. cit, p. 194.
} 
básicas entre o mercado de bolsa e o mercado de balcão organizado, quais sejam, neste último ao contrário das Bolsas (a) é possível a realização de operações sem a participação direta de intermediários integrantes do sistema de distribuição de valores mobiliários, (b) não obrigatoriedade de divulgação contínua das informações sobre os negócios realizados e (c) na possibilidade de registro de negócios bilaterais, "sem base em parâmetros de formação pública de preços". ${ }^{254}$

Dadas as características específicas de seu sistema de negociação, as Bolsas são capazes de garantir a formação pública de preços de todos os papéis em circulação no seu recinto, os quais são informados a todos os participantes daquele mercado em tempo real à realização dos negócios. Os mercados de balcão, a depender do papel, são capazes de fornecer a cotação de mercado de um dado título, mas não é sempre que tal é possível.

Portanto, pode-se dizer que os "títulos e valores mobiliários com cotação em mercado" são os valores mobiliários cujas negociações, seja em Bolsa de Valores, seja em mercado de balcão organizado, resultem em um preço ou uma cotação de mercado de aferição imediata.

Isto não quer dizer que valores mobiliários cuja cotação de mercado não seja imediatamente aferível em sistema organizado de negociação, não tenham significação econômica. Tudo dependerá dos atributos específicos de cada bem e de sua avaliação econômica para se verificar a conveniência e a eficácia da realização da penhora. Caso sejam títulos idôneos e com boa liquidez, não há dúvida de que sua penhora é preferível a bens de menor liquidez. Ainda que os valores mobiliários sem cotação em mercado devam ser por Lei classificados como "outros direitos" (CPC, art. 655, XI), o último bem na ordem legal de preferência, pode o Juiz, a depender das circunstâncias concretas, determinar a penhora destes bens ao invés de outros menos líquidos, embora, em tese, preferíveis pela classificação legal, pois, como já vimos, a ordem do art. 655 do Código de Processo Civil admite interpretação flexível.

\footnotetext{
${ }^{254}$ op.cit, p. 239.
} 


\subsubsection{Modo de apreensão}

Como não seria possível dentro do escopo desta dissertação tratar do modo de apreensão e das específicas características de cada um dos valores mobiliários com cotação em mercado, os quais se constituem sob regimes jurídicos variados, tomaremos como referência de nossa análise a ação de emissão de sociedade anônima aberta. Da ação de emissão de sociedade anônima fechada, sem circulação no mercado, trataremos no item 4.7 deste trabalho.

A ação de emissão de companhia aberta é instrumento representativo de fração negociável do capital social da companhia, que confere ao seu titular todos os direitos e obrigações do acionista. ${ }^{255}$ As ações podem ser emitidas pela companhia em pelo menos duas espécies distintas, as "ordinárias" e as "preferenciais", diferenciadas conforme o conjunto de direitos conferidos a seu titular. A "ação ordinária" confere a seu titular todos os direitos inerentes ao status de sócio, especialmente o direito a voto; a ação preferencial garante a seu titular certas vantagens em relação à ação ordinária como, por exemplo, a prioridade na distribuição de dividendos, mas usualmente não conferem ao acionista o direito de voto. ${ }^{256}$

Além das ações, as sociedades anônimas podem emitir outros valores mobiliários, dentre os quais, as debêntures são as mais conhecidas. Trata-se de títulos de crédito ofertados pela companhia em mercado que "designa o direito de crédito de seu titular contra a companhia emissora, em razão de um empréstimo por ela contraído". ${ }^{257}$ Como em um empréstimo, as debêntures garantem a seu titular o recebimento de uma remuneração sobre o capital investido, mas podem ser concebidas com outros arranjos, como participação nos lucros da companhia, ou a possibilidade de conversibilidade dos títulos em ações. ${ }^{258}$

\footnotetext{
255 cf. Modesto Carvalhosa (Comentário à Lei das Sociedades Anônimas, v. 1, p. 87).

256 cf. Eizirik, Gaal, Parente, et al. (Mercado de Capitais - Regime Jurídico, p. 57).

257 id., ibidem, p. 66.

${ }^{258}$ id., ibidem, p. 66-74.
} 
As ações são negociáveis em Bolsa de Valores. As debêntures são usualmente títulos negociáveis em mercado de balcão. Há outros valores mobiliários que não são de emissão de sociedades anônimas, mas que são negociáveis em mercados organizados de Bolsa de Valores ou de balcão. Exemplos de tais espécies de valores mobiliários são os contratos de derivativos ou determinadas espécies de cotas de fundo de investimento.

Como regra geral, dada a característica inerente ao valor mobiliário de ser passível de negociação em mercado, e sua natureza, quase sempre, de ser bem incorpóreo e escritural, é normalmente por meio de ordem judicial de indisponibilidade, com fundamento no rito-base dos artigos 671 e 672 do Código de Processo Civil, que se dá a afetação do valor mobiliário ao juízo da execução, como veremos a seguir ao analisarmos a penhora de ações.

As ações há muito tempo deixaram de ser representadas por documentos corpóreos ou certificados. As ações negociadas em Bolsa de Valores são títulos ou instrumentos meramente escriturais. Sua existência, bem como a titularidade do acionista, é comprovada pelo registro eletrônico em nome do acionista em uma instituição financeira depositária, independente da companhia emissora das ações (Lei 6.404/76, art. 35, caput).

No âmbito da BM\&FBOVESPA, ${ }^{259}$ Bolsa na qual as ações de companhias abertas são negociadas no Brasil, a negociação em Bolsa depende de serem as ações escriturais custodiadas em um sistema de custódia e liquidação próprio para realização de transações em mercado. Hoje, este sistema é operado pela Companhia Brasileira de Liquidação e Custódia (CBLC). ${ }^{260}$

O acionista, por intermédio de uma corretora de valores mobiliários autorizada a operar em Bolsa, transfere a custódia e a propriedade fiduciária das suas ações

\footnotetext{
${ }^{259}$ Para este tópico, foram importantes as ponderações feitas pelo Dr. Luiz Eduardo Martins Ferreira, ex-diretor jurídico da Bovespa, em conversa que tivemos a respeito do funcionamento do mercado de Bolsa e dos problemas atinentes à penhora neste âmbito.

${ }^{260}$ Sobre o assunto, ver relatório da Comissão de Valores Mobiliários denominado Os serviços de custódia e de ações escriturais, disponível no endereço etrônico http://www.cvm.gov.br/port/protinv/caderno2.asp.
} 
(Lei n. 6.404/76, art. 41) à CBLC. Estas ações são identificadas em contas mantidas em nome do acionista na CBLC para operacionalizar as transferências para outros participantes do mercado, que também são identificados por contas abertas na CBLC. As transações entre os participantes do mercado, sempre por intermediação das corretoras de valores, são então realizadas por este sistema de contas correntes. Segundo Eizirik, Gaal, Parente, et al., “... em linhas gerais, no dia de liquidação da operação, o título é retirado da conta mantida junto à CBLC pelo vendedor e incluído na conta mantida pelo comprador. Ao mesmo tempo, o valor relativo ao preço pago por este título é debitado da conta do comprador e creditado na conta do vendedor. Este procedimento de troca dos títulos pelo valor pago é realizado automaticamente pela CBLC, sem interferência dos participantes do negócio". ${ }^{261}$

A CBLC evidentemente não tem o poder de dispor das ações, mas a obrigação de devolvê-las ao acionista na mesma qualidade e quantidade no momento em que solicitado. A CBLC pode ainda exercer determinados direitos em nome do acionista, como, por exemplo, receber dividendos e outros proventos, os quais são posteriormente repassados ao acionista. ${ }^{262}$

A penhora de ações escriturais passíveis de negociação em Bolsa de Valores deve se analisar a partir de duas situações distintas.

Na primeira, as ações escriturais não estão custodiadas na CBLC. Deve então o Juiz, primeiramente, determinar à instituição depositária das ações escriturais que bloqueie qualquer tipo de negociação com as ações escriturais pertencentes ao executado, de modo a evitar qualquer ato fraudulento do Executado de se desfazer de sua posição em ações. Após o bloqueio, o Juiz deverá determinar a lavratura do auto ou termo de penhora das ações, nomeando a própria instituição depositária das ações escriturais como depositária da penhora, devendo em seguida determinar a averbação da penhora “...nos livros da instituição

\footnotetext{
261 cf. Mercado de Capitais - Regime Jurídico, p. 213.

${ }^{262}$ Sobre custódia de ações fungíveis ver José Edwaldo Tavares Borba (Direito Societário, p. 263/265).
} 
financeira" depositária "que os anotará no extrato da conta de depósito fornecido ao acionista" (Lei 6.404/74, art. 40, caput). ${ }^{263}$

Se as ações escriturais estiverem custodiadas na CBLC para negociação em mercado, a penhora também dependerá de medida prévia à formalização do auto de penhora, consistente em uma ordem judicial à CBLC, como custodiante e proprietária fiduciária das ações escriturais em nome do executado, para que bloqueie a negociação das ações com terceiros, indisponibilizando sua negociação. Após, o Juiz deve determinar a lavratura do auto de penhora, nomeando a própria CBLC como depositária das ações. Feito isto, deve-se determinar a averbação da penhora nos livros da instituição depositária das ações escriturais, conforme explicado acima.

Em razão da volatilidade inerente ao mercado acionário, sempre a depender do caso concreto, pode-se entender por bem proceder à alienação antecipada das ações penhoradas, mas para tanto devem se observar necessariamente os requisitos do art. 670 do Código de Processo Civil. Tal alienação deverá se dar por corretora de valores mobiliários autorizada a operar no mercado de Bolsa, nos termos do art. 704 do Código de Processo Civil.

\subsubsection{Efeitos}

Os valores mobiliários com negociação em mercado são, em regra, bens móveis e incorpóreos.

Por se constituírem em bens incorpóreos, de fácil e rápida movimentação, passíveis de negociação em mercado organizado, será por determinação judicial de indisponibilidade do ativo financeiro de titularidade do executado que se dá sua apreensão judicial. Trata-se, em regra, da única maneira de afetar o valor mobiliário ao juízo da execução, impossibilitando que o bem continue a circular em mercado ou neste seja

\footnotetext{
${ }^{263}$ Conforme ensina Modesto Carvalhosa, “...deve ser averbado qualquer ato judicial que impeça a negociação das ações nominativas registradas e escriturais, como a penhora e o seqüestro, e, da mesma forma, as cláusulas de inalienabilidade temporária ou vitalícia". cf. Modesto Carvalhosa (Comentários à lei das sociedades anônimas, v. 1, p. 284).
} 
liquidado. Por assumirem forma escritural, os valores mobiliários são passíveis de depósito (guarda e custódia).

No caso específico das ações, embora o acionista fique impedido de negociar suas ações, pode se discutir se os frutos, como os dividendos ou outros proventos, são abrangidos pela penhora. Isto porque da apreensão das ações não decorre automaticamente a apreensão de seus dividendos, os quais são pagos em função do desempenho da companhia e não do desempenho do papel em si. Trata-se de situação diferente da poupança, cujos juros só podem ser pagos a partir de um resgate parcial do investimento; ou do CDB cujos juros usualmente estão atrelados ao vencimento do título; ou mesmo da cota de fundo de investimento cujo pagamento da remuneração também depende de ordem de resgate ao menos parcial do investimento. Assim, entendemos que não é efeito automático do ato de apreensão das ações, haver restrições ao aproveitamento pelo acionista dos frutos. Caberá requerimento específico neste sentido pelo exeqüente para que os frutos também possam ser objeto de penhora. Quanto aos direitos não patrimoniais, como os de votar, continuam a serem exercidos normalmente pelo acionista. ${ }^{264}$

Assim, no caso dos valores mobiliários com cotação em mercado, deverá se verificar as características de cada bem específico para se avaliar o impacto que a penhora terá sobre o exercício dos poderes de gozar o bem pelo executado.

\footnotetext{
${ }^{264}$ Neste ponto, pode-se fazer uma analogia com os efeitos do penhor sobre ações. Sobre isto, nos diz Modesto Carvalhosa: “Em princípio, o penhora sobre a ação não transfere ao credor pignoratício o direito de voto, nem o de receber dividendos e demais vantagens patrimoniais ou pessoais decorrentes da qualidade de sócio. Presumese que tais prerrogativas serão exercidas pelo devedor, titular da ação empenhada. [...]" (Comentários à Lei de Sociedades Anônimas, vol 1, p. 279).
} 


\subsection{Penhora dos títulos da dívida pública com cotação em mercado}

\subsubsection{Os títulos da dívida pública}

Os "títulos da dívida pública" são títulos pelos quais a União, Estados, Distrito Federal e Municípios captam recursos financeiros no âmbito interno ou externo para financiar suas atividades, mediante autorização legislativa do Senado Federal (CF, art. 52, inciso VII).

A Lei Federal n. 10.179/2001 dispõe sobre a emissão de títulos da União Federal, a finalidade das emissões, as formas de emissão, etc. Em síntese, a União Federal emite os títulos para financiar o déficit orçamentário, refinanciar a dívida pública e para realizar operações específicas, definidas em Lei. As emissões são feitas sob a forma de oferta pública para instituições financeiras (leilões), oferta pública para pessoas físicas ("tesouro direto") e emissões diretas, em situações específicas. As emissões são feitas pelo Tesouro Nacional, órgão responsável pela execução da política fiscal. O Banco Central do Brasil faz por sua vez operações com títulos emitidos pelo Tesouro Nacional no mercado secundário para fins de execução da política monetária da União. ${ }^{265}$

Estados, Distrito Federal e Município têm maiores limitações à emissão de títulos da dívida pública, sendo mais relevante a atuação da União Federal nesta seara, até pela natureza de suas funções institucionais relacionadas ao funcionamento da economia do país.

Os títulos públicos são hoje emitidos sob a forma escritural e suas operações são realizadas em sistema centralizado de liquidação e custódia (Lei $\mathrm{n}$. 10.179/2001, art. $5^{\circ}$.). Os títulos de emissão do Tesouro Nacional são negociados por meio de leilões a instituições financeiras no âmbito do Sistema Especial de Liquidação e Custódia

\footnotetext{
${ }^{265}$ Tratam-se de informações constantes na página na internet do Tesouro Nacional sobre operações da dívida pública no mercado nacional, de 15/01/09, no endereço eletrônio www.stn.fazenda.gov.br/divida_publica/op_mercado_nacional.asp.
} 
(SELIC), gerido pelo Banco Central do Brasil em parceria com a Associação Nacional das Instituições de Mercado Aberto - ANDIMA. ${ }^{266}$ O SELIC é responsável também pela custódia dos títulos. Nos casos em que os títulos públicos federais são destinados a pessoas físicas (“Tesouro Direto"), a liquidação e custódia das operações é feita no âmbito da CBLC. ${ }^{267}$ Os títulos públicos de emissão de Estados e Municípios podem também ser custodiados e negociados em sistema de balcão organizado, tal como a Câmara de Custódia e Liquidação CETIP. $^{268}$

Os títulos da dívida pública "com cotação em mercado" do artigo 655, inciso IX, do Código de Processo Civil, são aqueles de emissão das entidades da Federação cuja negociação em sistema organizado de negociação resulte em um preço ou uma cotação de mercado de aferição imediata. Embora do dispositivo legal não haja referência a títulos de emissão do Município, não vislumbramos qualquer razão para não incluir na classe preferencial do referido dispositivo legal também os títulos cotados em mercado de responsabilidade dos Municípios. Não há, tampouco, lógica na determinação legal de colocar os títulos públicos cotados em mercado no nono lugar na ordem de preferência para penhora. Deveriam estar, dada a elevada liquidez de tal espécie de bem, junto com os "titulos e valores mobiliários com cotação em mercado", logo abaixo do dinheiro e da "aplicação em instituição financeira”. Esta é aliás a lógica seguida pela Lei da Execução Fiscal (Lei n. 6.830/80), ao colocar os títulos da dívida pública e os valores mobiliários cotados em mercado em segundo lugar na ordem dos bens preferencialmente penhoráveis, abaixo apenas do "dinheiro".

No mais, cabe enfatizar, que títulos públicos idôneos e com boa liquidez, ainda que não tiverem cotação em mercado, podem ser preferíveis para penhora do que outros bens de menor liquidez constantes do rol do art. 655 do Código de Processo Civil. Tudo dependerá dos atributos específicos de cada título e de sua avaliação econômica para se verificar a conveniência e efetividade de realização da penhora sobre tais títulos, ainda que

\footnotetext{
${ }^{266}$ Conforme informações constantes na página da internet do Banco Central do Brasil no endereço eletrônico http://www.bcb.gov.br/SPBSELIC.

${ }^{267}$ Trata-se de informações constantes na página na internet do Tesouro Nacional sobre operações da dívida pública no mercado nacional no endereço eletrônico http://www.stn.fazenda.gov.br.

268 Conforme informações constantes do "Cadernos de Legislação" da CETIP, atualizado em 02/02/2002, disponível em sua página na internet, http://www.cetip.com.br.
} 
devam ser classificados na classe de "outros direitos" do art. 655, inciso XI, do Código de Processo Civil.

\subsubsection{Modo de apreensão}

O "título da dívida pública com cotação em mercado" é título que espelha um "crédito" em favor do beneficiário do título em face da entidade governamental emissora. Por ser um título escritural a apreensão física do título não é possível. A titularidade do título pelo seu beneficiário-credor é comprovada pelos registros existentes em seu nome nos sistemas informatizados da entidade custodiante do título.

Em razão disso, a apreensão judicial deste "crédito" só pode se dar por ordem judicial de indisponibilidade do título a ser cumprida pela entidade custodiante, pois esta é a única maneira do Juiz conservar o bem e afetá-lo ao Juízo da execução, impedindo que o Executado venha a negociar o título com terceiros (CPC, art. art. 671, II) ou, caso seja possível pelas regras aplicáveis à emissão, proceda ao resgate antecipado do título junto à entidade emissora e devedora (CPC, art. 671, I).

Pois bem, no caso de título federal negociado no âmbito da SELIC, ao Banco Central do Brasil, deve ser destinada a ordem judicial de indisponibilidade do título; no caso do sistema "Tesouro Direto", caberá à CBLC como custodiante dos títulos federais dar cumprimento à ordem e no caso de títulos estaduais e municipais negociados e custodiados no âmbito da CETIP caberá a esta dar cumprimento à ordem de indisponibilidade do título pelo seu beneficiário.

Feito bloqueio do título, nos mesmos moldes da penhora de ativos financeiros e valores mobiliários com cotação em mercado, caberá ao Juiz determinar a lavratura do auto de penhora com nomeação da entidade custodiante do título como depositária. 


\subsubsection{Efeitos}

Os títulos da dívida pública são, atualmente, emitidos na modalidade escritural, constituindo-se em bens móveis e incorpóreos.

Por se constituírem em bens incorpóreos, representativos de "crédito", de fácil e rápida movimentação, a apreensão ocorre por determinação judicial de indisponibilidade do título pelo executado. $\mathrm{Na}$ forma escritural, os ativos financeiros são passíveis de depósito (guarda e custódia) na própria instituição custodiante do título.

Títulos públicos emitidos no passado, que se corporifiquem em documentos, são passíveis de penhora por meio de apreensão física do documento (CPC, art. 672, caput).

O executado perde os poderes de dispor e de gozar o bem.

\subsection{Penhora de créditos}

\subsubsection{O crédito}

O "crédito" é instituto do Direito das Obrigações e deve ser entendido como a "prestação", suscetível de estimação econômica, passível de pagamento pelo devedor ao credor, em função de obrigação contraída pelo primeiro. ${ }^{269}$

Caso a prestação seja de pagar dinheiro, o "crédito" pode se formalizar, desde que preenchidos os requisitos legais, como título de crédito, instrumento destinado à "circulação dos direitos de crédito", cujas características são a "literalidade", só vale o que está escrito, "autonomia", a obrigação assumida por alguém no título não se vincula

${ }^{269}$ cf. Washington de Barros Monteiro. (cf. Curso de Direito Civil, $4^{o}$.Vol, $1^{a}$. Parte, p. 3-11 e 17-22). 
a qualquer outra obrigação, e "abstração", a obrigação consignada no título independe da obrigação que lhe deu causa. ${ }^{270}$

Os direitos de crédito de natureza obrigacional são reputados para efeitos legais bens móveis, nos termos do art. 83 do Código Civil, inciso III do Código Civil, inserindo-se, portanto, na ordem de preferência legal para a penhora no inciso III do art. 655 do Código de Processo Civil. Os demais direitos com conteúdo patrimonial, não incidindo sobre nenhum dos bens mencionados nos incisos I a X do Código de Processo Civil, ficam em último na preferência legal para penhora (inciso XI).

\subsubsection{Modo de apreensão}

No capítulo 3.4.2.1. já discorremos sobre o procedimento de penhora de "crédito", pois este é o regime-base para a penhora de outros bens imateriais, tais como as já analisadas penhoras de dinheiro em instituição bancária, "aplicação em instituição financeira", valores mobiliários, títulos da dívida pública e outros bens incorpóreos.

Neste tópico, nos resta apreciar a importante questão atinente às atitudes que o terceiro (debitor debitoris) pode tomar em relação à penhora.

Caso o debitor debitoris pague a dívida em Juízo, não há nenhuma dúvida. Ele se exonera da obrigação (CPC, art. 672, p. $2^{\circ}$ ) e a penhora passa a incidir sobre o dinheiro depositado em instituição financeira (CPC, art. 666, I). Caso o debitor debitoris, confesse a dívida ele será havido como depositário da importância pertinente ao "crédito" e só se exonerará de sua obrigação mediante o depósito em Juízo (CPC, art. 672, p. $1^{\circ}$.). O silêncio do debitor debitoris, entende a doutrina majoritária, implica na presunção de existência do "crédito" e na normal continuidade da execução até sua expropriação. ${ }^{271}$ A negativa fraudulenta do debitor debitoris obviamente será considerada em "fraude à execução" e

\footnotetext{
270 cf. Fran Martins (Títulos de Crédito, $1^{\circ}$. vol., p. 9-15).

271 cf. Araken de Assis (Manual da execução, p. 643) como também Bruno Garcia Redondo e Mário Vitor Suarez Lojo (Penhora, p. 194)
} 
completamente ineficaz (CPC, art. 672, p. $3^{\circ}$.), mas o Código de Processo Civil é praticamente omisso na definição do procedimento a ser seguido para se apurar se a negativa do debitor debitoris é fundada ou não.

Araken de Assis sugere, a partir da parca disposição do art. 672, § $4^{\mathrm{o}}$., do Código de Processo Civil, que se instaure incidente processual, provocado por qualquer das partes ou mesmo o debitor debitoris, e com ampla garantia de defesa e produção de todos os meios de prova admissíveis, especialmente o depoimento do executado e do debitor debitoris, e eventual prova pericial, para se apurar a existência ou não do "crédito". Diz ainda que esta decisão será interlocutória e que caberá ainda embargos de terceiro pelo debitor debitoris, nos termos do art. 1046, caput, do Código de Processo Civil. ${ }^{272}$ Pois bem, a partir desses comentários de Araken de Assis e das lições de Pontes de Miranda, ${ }^{273}$ nos parece que sendo negativa ou positiva a decisão do incidente, sobre a existência ou não do "crédito", esta só terá o alcance de permitir ou não o prosseguimento da execução e expropriação do "crédito", o qual ainda poderá ser discutido nas vias de conhecimento, seja pelo debitor debitoris para obter desconstituição do "crédito", seja pelo executado para declarar sua existência, a depender da solução do incidente de verificação do "crédito" na ação de execução.

Por fim, para fechar este capítulo, cabe dizer que se o "crédito" a ser penhorado em Juízo estiver sendo objeto de cobrança em ação judicial a penhora se faz necessariamente no rosto dos autos do processo, nos termos do art. 674 do Código de Processo Civil.

\subsubsection{Efeitos}

Conforme já tivemos oportunidade de discutir no capítulo 3.4.2.1., a Doutrina majoritária entende que a penhora de "crédito" não implica na perda pelo executado do poder de dispor, mas apenas na ineficácia relativa do eventual ato de disposição. Conforme

\footnotetext{
272 cf. Araken de Assis (Manual da execução, p. 644/645).

273 cf. Comentários ao Código de Processo Civil, tomo XIII, p. 251/259.
} 
dissemos, na nossa visão, isto só é assim porque o Juiz não tem meios à sua disposição, na penhora do "crédito" puro, de impedir que o executado aliene seu direito a terceiros, pois as intimações do art. 671, incisos I e II, do Código de Processo Civil objetivam a indisponibilidade do bem, o que, no caso do "crédito", significa também a perda do exercício dos poderes de gozo pelo executado.

Nesse contexto, caso por algum motivo o executado transfira o seu "crédito" a terceiros ou o debitor debitoris ao invés de fazer o pagamento em Juízo o faça para o executado, este ato de disposição do crédito será ineficaz em relação ao processo, motivo pelo qual o debitor debitoris continuará obrigado a fazer o depósito do montante equivalente ao "crédito" em Juízo.

Em qualquer caso, a penhora de "crédito" se considera aperfeiçoada, inclusive para os efeitos do direito de preferência do art. 612 do Código de Processo Civil, a partir do momento que o debitor debitoris é intimado a não pagar o credorexecutado, nos termos art. 671, inciso I, do Código de Processo Civil. ${ }^{274} \mathrm{O}$ auto de penhora só se faz necessário no caso de apreensão física de títulos de crédito pelo Oficial de Justiça, os quais deverão ser obrigatoriamente depositados em instituição bancária (CPC, art. 666, I).

\subsection{Penhora de ações e cotas de sociedades empresárias}

\subsubsection{As ações e as cotas das sociedades empresárias}

A sociedade empresária é aquela que desenvolve atividade economicamente organizada para produção e circulação de bens e serviços. São denominadas "simples" as demais sociedades (CC, art. 982). ${ }^{275} 276$

\footnotetext{
274 cf. Araken de Assis (Manual da execução, p. 642).

275 cf. Priscila M.P. Corrêa da Fonseca e Raquel Sztajn (Código Civil Comentado, v. XI, p. 89).

${ }^{276}$ Segundo José Edwaldo Tavares Borba a sociedade simples regulada pelo Código Civil de 2002 se apresenta como uma reformulação da antiga "sociedade civil". (Direito Societário, p. 85).
} 
A sociedade empresária deve se organizar obrigatoriamente sobre um dos seguintes tipos: "sociedade em nome coletivo", "sociedade em comandita simples", "sociedade limitada", "sociedade anônima" e "sociedade em comandita por ações" (CC, art. 982). O instrumento representativo da fração ideal do capital social da "sociedade anônima" e da "sociedade em comandita por ações" são as "ações". Nas demais sociedades empresárias os direitos sobre fração ideal do capital social são denominadas cotas sociais. Portanto, a tais “ações" e "cotas" se refere o art. 655, inciso VI, do Código de Processo Civil, embora não haja nenhum impedimento à penhora de cotas das sociedades "simples" cuja classificação na ordem preferencial de penhora deve ser feita na classe dos "outros direitos" (CPC, art. 655, $\mathrm{XI})$.

$\mathrm{Na}$ prática, as sociedades empresariais normalmente se organizam sob a forma de "sociedade limitada" ou "sociedade anônima". Por isso, nossa análise não abrangerá os outros tipos legais de sociedades empresárias.

A "sociedade anônima" clássica foi concebida para ser uma sociedade fundamentalmente de capitais, na qual o mais importante para os sócios é a aglutinação de capitais, pouco importando a pessoa dos demais sócios. ${ }^{277}$ Por isso, as ações, títulos representativos da participação do acionista no capital social, deveriam ser livremente transmissíveis para quaisquer pessoas. Com a evolução deste tipo societário, explica Modesto Carvalhosa, este princípio foi relativizado para acomodar determinadas situações fáticas em que a organização de empresa como sociedade anônima é desejável, mas por outro lado "a qualidade do acionista tenha certa importância". ${ }^{278}$ É o que ocorre na Lei Brasileira que contempla as sociedades anônimas "fechadas", cujo estatuto pode criar determinadas restrições à transmissibilidade das "ações" a terceiros (Lei n. 6.404/76, art. 36), as quais também não são passíveis de negociação no mercado de valores e mobiliários (Lei n. 6.404/76, art. $4^{\circ}$, caput). No outro pólo, estão as "sociedades anônimas abertas" que procuram

\footnotetext{
277 cf. Modesto Carvalhosa (Comentários ao Código Civil, v. 13, p. 35).

278 cf. Modesto Carvalhosa (Comentários à Lei das Sociedades Anônimas, v. 1, p. 262).
} 
"recursos de capital próprio (ações) ou de terceiros (debêntures) junto ao público, oferecendo a qualquer pessoa desconhecida ações e debêntures de sua emissão". ${ }^{279}$

A "sociedade limitada" por sua vez sempre se caracterizou por ter atributos tanto de sociedade de capital, especialmente pela limitação da responsabilidade de seus sócios, como de sociedade de pessoas, especialmente pela possibilidade de se restringir a livre cessão dos direitos sobre cotas representativas de fração ideal de seu capital social a terceiros. $^{280}$

Nesse sentido, a "sociedade limitada" se aproxima da "sociedade anônima fechada", na medida em que o ingresso de terceiros na sociedade é passível de restrições e também porque não há negociação em mercado dos bens ou direitos representativos de fração ideal de seu capital social.

Disto resulta que, embora os regimes jurídicos de tais sociedades sejam distintos, sob o ponto de vista econômico a liquidez tanto de ações de sociedades fechadas, como das cotas sociais de sociedades limitadas, fica, em regra, prejudicada pela ausência de negociação de tais bens em mercado, ao contrário do que ocorre com as ações de sociedades anônimas aberta cotadas ou negociadas em Bolsa de Valores.

Há também certas peculiaridades importantes no modo de apreensão de títulos negociados em mercado, motivo pelo qual preferimos tratar da penhora das ações negociadas em mercado no capítulo dedicado aos "títulos e valores mobiliários com cotação em mercado". Neste capítulo, trataremos do modo de apreensão das cotas sociais de limitadas e das ações de companhia fechada, as quais passamos brevemente a definir.

Já tivemos oportunidade de mencionar que a "ação" é um valor mobiliário caracterizado por ser instrumento de participação no capital social de uma

\footnotetext{
279 cf. Modesto Carvalhosa (Comentários à Lei das Sociedades Anônimas, v. 1, p. 31).

280 cf. Modesto Carvalhosa (Comentários ao Código Civil, v. 13, p. 36/37).
} 
sociedade anônima, o qual confere a seu titular todos os direitos e obrigações pertinentes à sua condição de acionista.

A cota social da limitada por sua vez é "o conjunto de direitos, poderes, deveres e obrigações que decorrem do ser membro da sociedade, do status socii". ${ }^{281}$ Modesto Carvalhosa por sua vez vislumbra a cota social como direito sob duas perspectivas, uma patrimonial, "entendida como crédito relativo à percepção de lucros da sociedade e na eventual partilha da massa falida", e outra pessoal, "entendida como uma série de direitos inerentes à qualidade de sócio (status socii)". ${ }^{282}$

Sob esta perspectiva pessoal da cota social, ou seja, pela sua atribuição de direitos intuitu personae em relação aos demais sócios, a Doutrina e a jurisprudência muito discutiu a própria legalidade da penhora das cotas sociais de limitada, especialmente nos casos em que o contrato social vedasse a cessão pelo sócio dos direitos pertinentes à cota a terceiros, o que impediria sua adjudicação pelo exeqüente ou a alienação da cota em hasta pública.

Hoje, contudo, parece não haver mais margem à discussão sobre a possibilidade de penhora das cotas sociais, em razão das disposições permissivas expressas do art. 655, inciso VI, do Código de Processo Civil, e do art. 1026 do Código Civil. O fato é que a jurisprudência e a doutrina já vinham se inclinando há algum tempo e majoritariamente pela possibilidade de penhora das cotas sociais de limitada. Vale pôr foco sobre as conclusões havidas, pois tal nos será útil na análise dos efeitos que a penhora de cotas tem sobre o status socii.

Segundo Carlos Henrique Abrão:

“[...] A posição de cotista não se adquire pela simples penhora do quinhão social, porquanto, o status socii, compreende um conjunto complexo de direitos e obrigações de ordem econômica e pessoal.

\footnotetext{
${ }^{281}$ cf. Priscila M.P. Corrêa da Fonseca e Raquel Sztajn (Código Civil Comentado, v. XI, p. 434).

282 cf. Modesto Carvalhosa (Comentários ao Código Civil, v. 13, p. 68).
} 
Entendemos que se a cota for adquirida por terceiro, não querendo a sociedade o seu ingresso, deve-se liquidá-la, reduzindo o capital social, caso se necessite. [...]"283

É esta também a posição da jurisprudência dominante, valendo citar o acórdão do Superior Tribunal de Justiça relatado pelo Ministro Sálvio de Figueiredo Teixeira (RESP n. 30.854-2):

\begin{abstract}
"A penhorabilidade das cotas, porque não vedada em lei, é de ser reconhecida. Os efeitos de sua excussão, no entanto, hão de ser determinados em atenção aos princípios societários, considerandose haver, ou não, no contrato proibição à livre alienação das mesmas. Daí, na esteira do magistério de Carlos Henrique Abrão, entender que seja facultada à sociedade, na qualidade de terceira interessada, remir a execução sub-rogando-se nos direitos do credor, ou, ainda, remir o bem (CPC, art. 787) ou conceder-se à sociedade e aos demais sócios a preferência na aquisição das cotas, e tanto por tanto, aplicando-se os arts. 1117. 1118 e 1119, CPC, ou, ainda que sejam apurados os haveres do arrematante. Garante-se, desta forma, que possa a sociedade obstar a entrada em seu meio de pessoa indesejável. Não havendo restrição no ato constitutivo, nada impede que a cota seja arrematada com inclusão de todos os direitos a ela concernentes, inclusive o status de sócio". ${ }^{284}$
\end{abstract}

Verifica-se, então, ser plenamente possível a penhora de cotas sociais de limitada, a qual de maneira nenhuma afetará o exercício dos direitos pessoais inerentes ao exercício do status socii pelo executado. No momento da excussão judicial das cotas sociais se abre a questão pertinente à possibilidade de cessão a terceiros. Se isto for possível pelo contrato social da limitada, nada impede que o terceiro-adquirente da cota social venha a exercer seus direitos em sua plenitude, inclusive os de natureza pessoal do sócio. Se a cessão das cotas a terceiros não for autorizada pelo contrato social, cabe ao terceiro-adquirente requerer judicialmente a liquidação da cota social para que o valor patrimonial a ela correspondente seja vertido em dinheiro, nos termos do que determina o parágrafo único do art. 1026 do Código Civil.

283 cf. A Penhora de Cotas de Sociedade de Responsabilidade Limitada (p. 72).

${ }^{284}$ Trata-se de precedente citado por Murilo Zanetti Leal cuja referência completa é a seguinte: RESP 30.854-2SP, rel. Min. Sálvio de Figueiredo Teixeira, j. 8.3.1994, DJU 18.04.1994, RT 712/268-280. (cf. A Transferência Involuntária de Quotas nas Sociedades Limitadas, p. 74/75). 
Para finalizar este tópico, cabe evidenciar que o art. 1026, caput, do Código Civil se antepõe em evidente conflito à disposição do art. 655 do Código de Processo Civil. Isto porque o dispositivo da Lei Civil autoriza a penhora de cotas sociais apenas na “insuficiência de outros bens do devedor". Já o dispositivo da Lei Processual coloca as cotas sociais como o sexto bem na ordem de preferência para penhora, acima de quatro outros tipos de bem. Não é um conflito de fácil resolução. À primeira vista, conclui-se pela preponderância da Lei Processual, pela sua especialidade na matéria de execução e pela posterioridade do dispositivo processual (Lei n. 11.232/2006) em relação ao dispositivo do Código Civil. Por outro lado, é possível vislumbrar certo embaraço à sociedade que tem cotas representativas de seu capital social penhoradas, especialmente no momento da excussão destas cotas. Caberá ao Juiz analisar as peculiaridades do caso concreto e, se for o caso, sabido que o rol de preferência do art. 655 do Código de Processo Civil não é absoluto, preferir outros bens às cotas sociais, caso se vislumbre maior liquidez na transformação em dinheiro. Certamente este seria o caso, por exemplo, de um título de valor mobiliário ou de um título da dívida pública com cotação em mercado.

\subsubsection{Modo de Apreensão}

A cota social é bem móvel (CC, art. 83 , III $)^{285}$ ou direito incorpóreo. A sociedade limitada adquire personalidade jurídica a partir do registro de seu contrato social no Registro Público de Empresas Mercantis, a cargo da Junta Comercial (CC, art. 985 e 1150).

Para a penhora de cota social deverá o Juiz determinar a lavratura de auto de penhora, sendo despicienda a nomeação de depositário, em razão da natureza do bem que não é passível de depósito. Feito isto, o Juiz deve determinar a averbação da penhora nos registros da sociedade perante a Junta Comercial. Será esta providência que terá o condão de dar efeito erga omnes ao ato de da penhora, garantindo que eventuais atos de cessão de direitos pertinentes à cota serão completamente ineficazes perante o juízo da execução.

\footnotetext{
285 cf. José Edwaldo Tavares Borba (Direito Societário, p. 44).
} 
Já a ação de sociedade anônima fechada se constitui em instrumento de participação no capital da companhia, cuja propriedade é comprovada pela inscrição do nome do acionista no livro de "Registro de Ações Nominativas" da companhia. Para apreensão de tal bem, deve o Juiz determinar a lavratura do auto de penhora, sendo neste caso despicienda a nomeação de um depositário para ações cuja existência é impassível de corporificação física, tampouco de escrituração por um terceiro alheio à companhia. Após, nos termos do art. 40, inciso I, da Lei n. 6.404/76, deve-se averbar a penhora em referido livro societário.

Caso as ações da companhia fechada assumam forma escritural, quer dizer, sejam mantidas em contas de depósito em instituição financeira depositária, nos moldes do art. 34 da Lei n. 6404/76, a penhora segue o modelo já traçado no item 4.4. em que tratamos da penhora de ações escriturais de companhia aberta com negociação em mercado. Lavra-se o auto de penhora, nomeando-se a instituição depositária como depositária da penhora, e averba-se a constrição nos livros da instituição financeira depositária.

\subsubsection{Efeitos}

Tanto as cotas sociais como as ações de companhias fechadas são bens móveis e incorpóreos.

Apesar disto, duas características fazem com que sua apreensão não dependa de indisponibilidade dos bens para uma segura afetação ao Juízo da execução: (a) não se tratam de bens destinados a circularem em mercado e (b) a penhora é passível de averbação pública, sendo oponível a terceiros.

A averbação do ato de penhora, com efeito de fé pública, na Junta Comercial, no caso da limitada, e nos livros da companhia ou da instituição depositária de ação escritural, no caso das ações de companhia fechada, é providência essencial para que as 
cotas sociais e as ações de companhias fechadas sejam seguramente afetadas ao Juízo da execução, pois nenhum terceiro poderá alegar desconhecimento sobre a existência da penhora.

Não há perda do poder de disposição, mas há ineficácia relativa de quaisquer atos de disposição. Os poderes políticos inerentes à condição de sócio/acionista não são alterados por força de penhora. Quanto aos poderes de gozo, sua limitação dependerá de penhora específica sobre os frutos decorrentes da titularidade pelo executado das cotas sociais/ações.

\subsection{Penhora de imóvel}

\subsubsection{O imóvel}

$\mathrm{O}$ art. 79 do Código Civil define como bens imóveis "o solo e tudo quanto se lhe incorporar natural ou artificialmente". O direito à propriedade imóvel se adquire por usucapião e acessão (aquisição originária), bem como por transmissibilidade inter vivos, com transcrição do título aquisitivo no Cartório de Imóveis ou causa mortis (aquisição derivada), sendo certo em qualquer caso que o direito de propriedade se evidencia pelo registro no Cartório de Imóveis. ${ }^{286}$ Para todos os efeitos, se considera propriedade imóvel as partes ou unidades autônomas de edificações constituídas em Condomínio Edilício, suscetíveis de utilização independente (CC, art. 1331).

O Legislador estende ainda o mesmo regime legal dos bens imóveis aos "direitos reais sobre imóveis e as ações que os asseguram", bem como o "direito à sucessão aberta” (CC, art. 80).

O rol de direitos reais sobre imóveis é bastante vasto, não se restringindo ao direito de propriedade imóvel. Disto resulta que alguns direitos reais sobre

\footnotetext{
${ }^{286}$ cf. Maria Helena Diniz (Curso de Direito Civil Brasileiro, p. 103).
} 
imóveis, embora não haja uma regulação específica em nosso Código de Processo Civil, por suas características específicas, podem implicar na adoção de algumas providências de apreensão inerentes à penhora de imóvel, tal como o registro em alguns casos, e outras aplicáveis à penhora de direitos do art. 671 do Código de Processo Civil. É o que ocorre, por exemplo, ao "direito do promitente comprador do imóvel" (CC, art. 1225, VII), cuja penhora exige necessariamente a intimação ao promitente vendedor do imóvel. ${ }^{287}$

Neste tópico restringiremos a nossa análise à penhora do direito de propriedade imóvel, o qual pode corresponder à integralidade do bem imóvel, como também à sua parte ideal ou quinhão.

\subsubsection{Modo de Apreensão}

Como já tivemos oportunidade de expor, a impossibilidade de remoção do bem imóvel pelo executado, bem como a possibilidade de se dar ciência sobre a existência da penhora via Cartório de Imóveis a terceiros que ficam inequivocamente informados da não produção de efeitos de qualquer ato de alienação do bem perante o Juízo da execução, fazem com que a apreensão ficta seja o método mais eficaz para a penhora de bem imóvel.

Nesse sentido, garantida a função da penhora de afetar o bem à futura expropriação judicial, em benefício do exeqüente, em regra, não há motivos que justifiquem o desapossamento do executado pela penhora, podendo ele próprio figurar como depositário do bem. Neste caso, não há porque se fazer a execução pelo modo mais gravoso ao Executado se a função da penhora é adequadamente cumprida sem a necessidade do desapossamento (CPC, art. 620).

\footnotetext{
${ }^{287}$ No Direito Português à penhora de "direito ou expectativa real de aquisição do executado" [...] "aplicam-se então as disposições relativas à penhora de direito de crédito, com as necessárias adaptações (art. 860-A-1). A penhora é feita por notificação à contraparte (promitente vendedor, pessoa sujeita à preferência, vendedor reservatório ou comprador sob condição resolutiva), a qual pode impugnar a existência do direito penhorado, invocar o direito a qualquer prestação de que a aquisição dependa, reconhecer o direito, fazer sobre ele qualquer outra declaração relevante ou nada declarar, tendo-se neste caso o direito como reconhecido, nos mesmos termos em que se tem por reconhecido o direito de crédito". (cf. José Lebre de Freitas, A acção executiva, p. 254).
} 
Por outro lado, fixada a premissa de que a função da penhora do imóvel é plenamente atingida com a apreensão ficta, deve-se considerar o benefício extra autos da apreensão ficta não desafetar imediatamente o imóvel de sua destinação econômica e social, seja moradia do executado, seja a locação a um terceiro, seja seu emprego em uma atividade empresarial. Ainda que pela natureza da execução forçada seja remota a possibilidade de desconstituição da penhora pelos meios de impugnação à execução, caso ocorra tal desconstituição os danos colaterais de uma penhora indevida ao executado e também à sociedade são bastante minimizados.

É evidente que não há nenhum impedimento legal, a depender das circunstâncias do caso concreto, de o Juiz determinar a penhora do imóvel via apreensão real, no caso, por exemplo, do Executado por impossibilidade de meios de manutenção do bem se recusar a exercer o encargo de depositário ou se houver fundadas razões que indiquem a possibilidade de deterioração e desvalorização do bem imóvel, caso o executado permaneça como depositário do bem. Trata-se toda de forma de exceções a serem verificadas pelo Juiz, em confronto com a escolha preferencial do Legislador pela modalidade ficta de apreensão.

Nos termos do art. 659, $\S 4^{\circ}$. e $5^{\circ}$., do Código de Processo Civil a penhora de imóvel se dá pela apresentação pelo exeqüente da certidão de matrícula do bem extraída do Cartório de Imóveis e, com base nesta, pela lavratura do termo de penhora em cartório, ainda que o bem se localize em outra Comarca. Após, o executado será intimado da penhora, pessoalmente ou via advogado constituído nos autos, e por este ato constituído depositário do bem.

Embora a Lei repute válida a intimação do executado via advogado constituído e por este ato considere configurada a assunção pelo executado ao encargo de depositário, a pena de prisão por depósito infiel só pode ser aplicada se houver assunção expressa do executado ao encargo de depositário, nos termos da jurisprudência pacífica do Superior Tribunal de Justiça já mencionada. Nessa linha, caso se queira garantir a aplicação desta penalidade, é recomendável que o exeqüente opte por proceder à intimação pessoal do executado. 
Fora isso, lavrado o termo de penhora o exeqüente deve retirar certidão judicial do inteiro teor do ato e averbá-la no Cartório de Imóveis respectivo para dar "presunção absoluta de conhecimento por terceiros".

A averbação não é requisito da penhora, pois esta se considera perfeita e acabada com a lavratura do termo. Todavia, é de fundamental importância a realização da averbação para que a penhora surta o efeito de tornar automaticamente ineficaz perante o Juízo da execução qualquer ato de alienação ou oneração do bem pelo executado a terceiros. Sem tal providência, a penhora de imóvel fica com sua eficácia sensivelmente limitada, na medida em que eventual ato de alienação do bem penhorado a terceiros só poderá ser reputado ineficaz se comprovado pelo exeqüente a insolvência do executado (CPC, art. 593, II), bem como os demais requisitos configuradores da fraude à execução, conforme interpretação da jurisprudência sobre tal instituto. ${ }^{288}$

Este problema não existirá caso o exequente tenha se utilizado da prerrogativa do novo art. 615-A do Código de Processo Civil, introduzido pela Lei n. 11.382/2006, e já ter tido o cuidado de averbar no Cartório de Imóveis a informação sobre a distribuição da ação de execução. ${ }^{289}$ Agindo desta forma, independentemente do ato de penhora e de sua posterior averbação, nos termos do parágrafo terceiro do referido dispositivo legal, "presume-se em fraude à execução a alienação ou oneração de bens efetuada após a averbação".

Outras formalidades complementares ao ato de penhora do imóvel são aquelas determinadas no artigo 655, parágrafos primeiros e segundo do Código de

\footnotetext{
${ }^{288}$ Conforme ensina Paulo Henrique dos Santos Lucon "a penhora, como ato público e solene de afetação patrimonial, não torna o bem indisponível, mas apenas ineficazes, relativamente ao exeqüente, atos de disposição praticados pelo executado que desrespeitem a constrição judicial. A afetação executiva segue o bem e a expropriação ocorrerá ainda que esse já não mais pertença ao executado. Todavia, como visto, o terceiro adquirente de boa-fé pode desconstituir a penhora pela via dos embargos de terceiro. Tal possibilidade somente é obstada pelo registro da penhora, que tinha como tem ainda, o escopo de dar eficácia erga omnes ao ato constritivo nas alienações do bem penhorado". (cf. "Fraude de execução, responsabilidade processual civil e registro da penhora” in $R P$ 98/161).

${ }^{289}$ Entendemos que esta prerrogativa seja extensível ao regime do cumprimento de sentença de obrigação de pagar.
} 
Processo Civil. No caso de execução, com garantia hipotecária, a penhora recairá preferencialmente sobre o bem hipotecado e caso a hipoteca tenha sido oferecida por terceiro garantidor este deverá também ser intimado da penhora. No caso de penhora de bem imóvel de executado casado, o seu cônjuge também deverá ser intimado da penhora.

Por fim, se o cônjuge não tiver responsabilidade sobre a dívida em execução, e sendo o bem imóvel indivisível, a penhora incide sobre o todo e a meação do cônjuge recairá sobre o produto da alienação do bem (CPC, art. 655-B).

\subsubsection{Efeitos}

No caso da penhora de imóvel, por ocorrer mediante apreensão ficta, conforme já tivemos oportunidade de expor no capítulo 3.5. deste trabalho, o Executado continua a manter a posse sobre o bem, mas na condição jurídica de depositário, o que o faz investido do dever legal de conservar e guardar o bem para o Juízo da execução até o momento da expropriação. Em regra, esta nova condição jurídica do executado não o impede de usar o bem, ou seja, de dar ao imóvel a mesma destinação social e econômica que vinha lhe sendo dada até o momento da penhora. Logicamente, está o executado impedido de dar ao imóvel qualquer destinação ao imóvel que o faça perecer ou diminuir o seu valor econômico. Os poderes de gozar o imóvel ficam limitados. A moradia pelo executado não é obstada. Como já dissemos no capítulo 3.5.2., a doutrina majoritária entende que os frutos gerados pela destinação econômica do imóvel, tais como a renda de locação, devem ser destinados ao Juízo da execução, independentemente de consignação expressa no auto de penhora, ressalvado nosso entendimento em contrário. Entende também a doutrina que, a depender das circunstâncias do caso concreto, o Juiz pode definir que os frutos sejam vertidos total ou parcialmente ao executado para suportar as despesas de manutenção do bem e/ou serem imputados como remuneração ao executado pelo exercício do encargo de depositário. Pode ainda o Juiz, após a avaliação do bem, limitar a extensão da penhora, afastando a incidência sobre os frutos, caso reste inequívoco que o valor do bem principal é suficiente para satisfazer a execução e seus consectários (CPC, art. 685, I). 
Por outro lado, nada impede que ao invés de recair sobre o bem principal, a penhora incida apenas sobre os seus frutos ou outros acessórios por aquele gerados, sendo certo que penhora deste tipo não mais seguirá o rito da penhora de imóvel, mas do tipo condizente à natureza do bem que se pretende penhorar. ${ }^{290}$

\subsection{Penhora de percentual de faturamento}

\subsubsection{O faturamento}

O termo "faturamento", de conotação não só jurídica, mas também contábil e econômica, é ora usado para se referir ao conjunto de faturas emitidas pelo empresário em decorrência do exercício de sua atividade empresarial; ora para designar o conjunto de faturas de vendas a crédito; ora para designar o resultado financeiro decorrente do recebimento de tais faturas; ora como o resultado financeiro decorrente de quaisquer receitas auferidas pelo empresário, seja por força do exercício de sua atividade empresarial típica, seja pelo resultado de operações de outra natureza, tais como ganhos obtidos por aplicação financeira. Enfim, trata-se de termo utilizado para descrever fenômenos correlatos, mas não necessariamente coincidentes.

Não é, assim, tarefa simples definir tal termo, mas como o faturamento de empresa é base de cálculo de contribuições e tributos federais, a busca de uma conceituação jurídica precisa do faturamento de empresa encontrou campo fértil no direito tributário. A Lei Complementar n. 70, instituidora da COFINS, define o faturamento mensal como "a receita bruta das vendas de mercadorias, de mercadorias e serviços e de serviço de qualquer natureza". Trata-se de conceito que se afina à origem do fenômeno comercial de

\footnotetext{
${ }^{290}$ Conforme anota Araken de Assis "nada impede a penhora em separado dos frutos, das pertenças, dos rendimentos, dos produtos, das plantações e das acessões, desde que não sejam partes essenciais, cuja constrição individual diminua ou destrua o valor da coisa principal. A extensão concreta da penhora dependerá do constante no respectivo auto (art. 665, II), salvo no caso do art. 34 da Lei 10.931/2004. Tanto o executado, quanto o credor, conforme o caso, podem nomear a coisa principal e seus acessórios, em conjunto ou isoladamente". (cf. Manual da execução, p. 599).
} 
faturar, ou seja, de emitir fatura, consistente em uma "[...] nota do vendedor, descrevendo a mercadoria, discriminando a sua qualidade e quantidade, fixando-lhe o preço, [...] o documento que positiva contrato de compra e venda mercantil ou prestação de serviços". ${ }^{291}$

Pois bem, em meio a intensas discussões judiciais sobre a constitucionalidade da Lei Ordinária n. 9718/98, a qual pretendia estender a base de cálculo da COFINS a quaisquer receitas auferidas pelas empresas, por meio de uma tentativa de ampliação do conceito de faturamento da Lei Complementar n. 70, o Supremo Tribunal Federal parece ter firmado posição no sentido de afirmar que "faturamento" não serve para designar quaisquer receitas auferidas pela empresa, mas apenas aquelas resultantes de sua atividade empresarial típica de vender mercadorias ou prestar serviços. Isto em linha com o art. 195, inciso I, alínea "b", da Constituição Federal, na redação dada pela Emenda Constitucional n. 20 de 1998, pelo qual a contribuição social poderia incidir sobre a "receita ou faturamento". De acordo com o voto do Ministro Marco Aurélio, relator do Recurso Extraordinário n. 346.084: “a disjuntiva 'ou' bem revela que não se tem a confusão entre o gênero 'receita' e a espécie 'faturamento"'. 292

Firmou-se, assim, conceito de faturamento adstrito a suas origens no Direito Comercial, nos termos já fixados na Lei Complementar n. 70 como a receita bruta advinda da venda de mercadorias ou serviços pela empresa, ou seja, a receita obtida com o exercício da atividade empresarial para a qual a empresa foi constituída.

A questão é saber se este mesmo conceito deve ser utilizado para qualificar juridicamente o bem "faturamento de empresa", objeto do art. 655, inciso VII, do Código de Processo Civil.

Não temos dúvida que sim, mas nada impede ao Juiz determinar que a penhora incida sobre outras receitas geradas pela empresa-executada, pois como já

\footnotetext{
${ }^{291}$ Esta é definição de "fatura" por Amador Paes de Almeida que ainda complementa com a definição de Carvalho de Mendonça: "fatura é escrito unilateral do vendedor e acompanha as mercadorias, objeto do contrato, a serem entregues ou expedidas".

${ }^{292}$ Trata-se de recurso extraordinário julgado pelo Supremo Tribunal Federal em 9 de novembro de 2005. A íntegra, com 212 páginas, está disponível na página da internet do STF, endereço eletrônico http://www.stf.jus.br.
} 
dissemos outras vezes no curso deste trabalho, o rol do art. 655 do Código de Processo Civil não se destina a arrolar todos os bens circulantes na economia que sejam passíveis de penhora. Impera aqui a regra do art. 591 do Código de Processo Civil, pela qual todos os bens presentes e futuros do Executado são passíveis de penhora. A exceção a este dispositivo está no art. 649 do Código de Processo Civil, e outras disposições legais esparsas, que trazem o rol dos bens impenhoráveis.

Sendo assim, o Juiz pode determinar a penhora do faturamento da empresa-executada como também de outras receitas por ela geradas, não decorrentes da emissão de faturas de venda de mercadorias ou prestação de serviços, enfim, não necessariamente decorrentes do exercício de sua atividade empresarial-fim. O importante nesta modalidade de penhora é reconhecer-se sua destinação a apreender percentual de renda, ou seja, do fluxo de valores recebidos pela empresa em determinado período de tempo. ${ }^{293}$ Não se trata de apreender um bem estático, um imóvel ou dinheiro depositado em determinado Banco, ou mesmo de um crédito detido pelo executado em face de um devedor específico, mas de parte de um fluxo financeiro recebido pela empresa-executada em um determinado período de tempo.

$\mathrm{O}$ art. 655 do Código de Processo Civil coloca o "percentual de faturamento de empresa devedora" como o sétimo bem preferencialmente penhorável, acima de pedras e metais precioso, títulos da dívida pública e valores mobiliários com cotação em mercado. Não consideramos tal classificação adequada, primeiro porque, como já vimos, havendo títulos mobiliários com cotação de mercado, sua penhora é largamente preferível, dada a liquidez de tais ativos. E segundo porque a classificação legal desconsiderou remansosa jurisprudência do Superior Tribunal de Justiça que só admite a penhora de faturamento em situações excepcionais, nas hipóteses em que não há outros bens suficientes a satisfazer o exequente. ${ }^{294}$ Nesse sentido, a penhora de faturamento, por mais bem conduzida que seja pelo

\footnotetext{
${ }^{293}$ Como anota Oliver Blanchard a renda é um fluxo expressa por unidade de tempo: renda semanal, mensal ou anual. (Macroeconomia, p. 74).

${ }^{294}$ Conforme excerto da ementa do acórdão que julgou o RESP 982.915/RJ, de relatoria do Ministro José Delgado: “[...] Na verdade, a jurisprudência mais atualizada desta Casa vem se firmando no sentido de restringir a penhora sobre o faturamento da empresa, podendo, no entanto, esta ser efetivada, unicamente, quando observados, impreterivelmente, os seguintes procedimentos essenciais, sob pena de frustrar a pretensão
} 
Juiz e o administrador, é gravosa ao exercício da atividade empresarial pela empresaexecutada, na medida em que se constitui em interferência judicial perene na destinação ou aplicação pela empresa-executada de seus recursos financeiros. Por isso, em aplicação ao art. 620 do Código de Processo Civil, havendo outros bens comprovadamente suficientes à satisfação da execução, a penhora de tais bens deve ser preferida. Mesmo porque, as dificuldades inerentes à realização das penhoras de faturamento e de empresa não as tornam especialmente mais eficazes do que outras modalidades de penhora.

Não havendo outros bens passíveis de penhora, a penhora de faturamento é alternativa existente à empresa-executada, até mesmo para se evitar caminhos mais drásticos, como seria a decretação da falência, por ausência de pagamento, depósito ou nomeação de bens à penhora em execução por quantia certa (Lei n. 11.101/05, art. 94, inciso II).

\subsubsection{Modo de apreensão}

Como vimos, a penhora de faturamento é um tipo muito especial de penhora pois ela não incide sobre um bem específico componente do patrimônio da empresaexecutada, mas sobre sua renda, sobre o fluxo de seus recebimentos periódicos. Por isso, o procedimento de apreensão judicial de percentual do faturamento de empresa tem peculiaridades muito próprias.

Primeiramente, deve-se apurar o faturamento da empresaexecutada, definindo-se claramente se a periodicidade de apuração será mensal, semanal ou

constritiva: - a verificação de que, no caso concreto, a medida é inevitável, de caráter excepcional; - a inexistência de outros bens a serem penhorados ou, de alguma forma, frustrada a tentativa de haver o valor devido na execução; - o esgotamento de todos os esforços na localização de bens, direitos ou valores, livres e desembaraçados, que possam garantir a execução, ou sejam os indicados de difícil alienação; - a observância às disposições contidas nos arts. 677 e 678 do CPC (necessidade de ser nomeado administrador, com a devida apresentação da forma de administração e esquema de pagamento); - "na penhora de percentual do faturamento da empresa executada, será nomeado depositário, com a atribuição de submeter à aprovação judicial a forma de efetivação da constrição, bem como de prestar contas mensalmente, entregando ao exeqüente as quantias recebidas, a fim de serem imputadas no pagamento da dívida" ( $\$ 3^{\circ}$ do art. 655-A do CPC, incluído pela Lei ${ }^{\circ}$ 11.382/2006); - fixação de percentual que não inviabilize a atividade econômica da empresa.[...]”. (DJU, 3/3/2008, disponível na íntegra no endereço eletrônico http://www.stj.gov.br). 
diária. O art. 655-A, $\S 3^{\circ}$., do Código de Processo Civil, não define expressamente, mas parece sugerir que esta modalidade de penhora deva incidir sobre o faturamento mensal ao pontuar que a prestação de contas deve ocorrer mensalmente. Em regra, entendemos ser o mais apropriado, pois é usual a toda empresa medir ou apurar seu faturamento ao menos mensalmente. Para apuração do faturamento mensal da empresa-executada pelo Juízo da execução, será necessária a nomeação pelo Juiz de um depositário, sem o que este tipo de penhora se torna completamente insubsistente, pois cabe ao depositário tomar as providências práticas e concretas para que a penhora funcione.

Mais precisamente deverá o depositário da penhora, nos termos do art. 655-A, $\S 3^{\circ}$., do Código de Processo Civil, (a) submeter à aprovação judicial a forma de efetivação da constrição, (b) prestar contas mensalmente e (c) entregar ao exeqüente as quantias recebidas, a fim de serem imputadas no pagamento da dívida.

Nitidamente, suas funções vão além daquelas exercidas pelo depositário, o qual, na sua concepção clássica, tem a responsabilidade de guardar e conservar o bem penhorado até o momento da expropriação. Na penhora de faturamento, não há apreensão física de bem e posterior depósito em mãos do depositário, tampouco simples guarda de bem de terceiro, mas há a outorga de determinados poderes pelo Juiz ao depositário para que este tome todas as providências cabíveis para retirar do faturamento ou da renda auferida periodicamente pela empresa-executada um montante financeiro à ordem do Juízo da execução, segundo critérios previamente definidos. Este é o encargo judicial com o qual o depositário se compromete, motivo pelo qual muito mais próprio seria designá-lo como um administrador.

Aliás, a penhora do faturamento da empresa-executada é modalidade de constrição derivada da penhora do estabelecimento comercial, mas limitada ao componente econômico da renda do estabelecimento, ou seja, incidente não sobre todo o estabelecimento comercial, mas sobre parte do fluxo de receita que o estabelecimento se destina a gerar ou, procurando dar uma qualificação jurídica à renda, sobre parte do dinheiro resultante do exercício da atividade empresarial em determinado período de tempo. Trata-se, 
em verdade, do direito à renda do art. 675 do Código de Processo Civil cujo produto não pode ser vertido simploriamente ao Juízo da execução, mas deve ser administrado conforme critérios pré-definidos, apurado mensalmente, descontado os valores necessários à manutenção do estabelecimento e, após, vertido o remanescente ao Juízo da execução.

Nesse sentido, apesar do objeto deste tipo de penhora ser parte da renda da empresa-executada, o modo de apreensão desta renda passa por medidas de administração. Tudo dependerá do plano de constrição judicial submetido e aprovado pelo Juiz, o que poderá implicar atos de efetiva administração da empresa pelo administrador judicial até atos de mera fiscalização do cumprimento do plano por parte da empresa executada. $^{295}$

Em qualquer caso, a começar pela elaboração do plano de constrição judicial, a tarefa do administrador judicial é complexa e a ordem judicial da penhora de faturamento só é passível de ser cumprida se a empresa-executada fornecer ao administrador todos as informações e elementos necessários para que a apreensão judicial possa ser concretizada. Como bem pontua Carlos Henrique Abrão a indicação do administrador "não representa 'tout court', interferência na vida societária, nem tampouco uma tentativa de devassa fiscal ou do sigilo bancário, uma vez que sem ter acesso aos dados da atividade produtiva, não se precisará o montante a ser depositado e muito menos a viabilidade da permanência desta ordem". ${ }^{296}$ Qualquer postura que obste o exercício pelo administrador de seu encargo poderá ser qualificada como ato atentatório à dignidade da justiça. De outro lado, cabe ao Juiz e a seu administrador, com a colaboração dos advogados das partes, zelar para que eventuais dados da empresa cobertos por sigilo legal não sejam disponibilizados para terceiros alheios ao processo, prática já usual nos cartórios, por exemplo, ao se manejar informações sigilosas fornecidas pela Receita Federal.

\footnotetext{
${ }^{295}$ Araken de Assis entende que o administrador da penhora de empresa, "poderá se investir [...] nos órgãos de direção, empregando o título - quotas ou ações, p. ex. - abrangido na constrição - tudo de acordo com a aprovação do Juiz. [...] Do contrário, corre-se o risco de inexistir 'faturamento' disponível para solver a dívida". (cf. Araken de Assis, Manual da execução, p. 654). Segundo o mesmo autor, todavia, a "forma" de execução da penhora poderá variar, indo do "simples recebimento de quantias previamente ajustadas do gestor da empresa à intervenção nos negócios”. (cf. Araken de Assis, Manual da Execução, p. 656).

296 cf. "A excepcionalidade da penhora" in Revista Dialética de Direito Tributário n. 32/24.
} 
Ademais, nada impede que o administrador judicial seja representante da empresa-executada, o que dependerá da anuência do exeqüente (CPC, art. $666, \S 1^{\circ}$.) e logicamente também da concordância expressa do representante da empresaexecutada, pois há entendimento que reputa pertinente a prisão do administrador por depósito infiel, o que “ [...] pode se manifestar durante a obrigação de efetuar o depósito, pela manipulação dos dados de balanço, pelo esvaziamento patrimonial, transferência da sede do negócio [...]", ${ }^{297}$ embora a jurisprudência do Superior Tribunal de Justiça caminhe para um entendimento mais restritivo à possibilidade de prisão do administrador/depositário. ${ }^{298}$

Dito isso, cabe agora tratarmos da forma de realização da penhora de faturamento. Ainda antes de ter sido a penhora do faturamento positivada em nosso Código de Processo Civil pela Lei n. 11.382/2006 o Superior Tribunal de Justiça firmou o entendimento de que a penhora de faturamento além de ser medida excepcional, só poderia ser feita pela nomeação de administrador que deveria apresentar formas de administração e pagamento, nos moldes do art. 678, parágrafo único, e art. 719, caput, do Código de Processo Civil, de modo a não inviabilizar a continuidade da atividade econômica pela empresaexecutada. ${ }^{299} \mathrm{O}$ art. 655-A, $\S 3^{\circ}$., do Código de Processo Civil não detalha o procedimento, mas fundamentalmente manteve o posicionamento firmado pelo Superior Tribunal de Justiça e deixa claro que o administrador deve submeter “à aprovação judicial a forma de efetivação da constrição".

Isto quer dizer que a penhora de faturamento deve ser precedida de uma providência prévia fundamental para sua eficácia, que é a apresentação pelo

\footnotetext{
297 cf. Carlos Henrique Abrão ("Depositário Judicial da Penhora de Faturamento" in Revista Dialética de Direito Tributário n. 59/10). Em sentido oposto, Araken de Assis entende que cabe a prisão do depositárioadministrador, no limite "do depósito da importância em relação à qual, efetivamente, aceitou o encargo, não podendo ser penalizado com a prisão civil vinculada a outros bens ou importância cujo depósito não assumiu perante o juízo" (Manual da execução, p. 654/655).

${ }^{298}$ Ver neste sentido o seguinte acórdão da lavra do Ministro Carlos Alberto Menezes Direito, no RHC 15201/RJ: “[...] Na hipótese de penhora de rendas da pessoa jurídica, a ausência de nomeação de administrador, por si só, não libera do encargo de depositário judicial aquele que o aceitou junto ao Poder Judiciário, devendo convenientemente cumpri-lo, zelando pelo bem objeto da constrição. 2. A responsabilidade do depositário judicial está limitada à guarda ou, no caso, ao depósito da importância em relação a qual, efetivamente, aceitou o encargo, não podendo ser penalizado com a prisão civil vinculada a outros bens ou importâncias cujo depósito não assumiu perante o juízo. [...]" (DJU, 2/2/2004; íntegra no http://www.stj.gov.br). É também o entendimento de Araken de Assis (Manual da execução, p. 654-655).

299 cf. Humberto Theodoro Júnior (Processo de execução e cumprimento de sentença, p. 283).
} 
administrador de um plano de realização prática da constrição de percentual do faturamento da empresa-executada, o qual deve atender dois objetivos, (a) afetar ou apreender, em determinado período de tempo, dinheiro resultante do faturamento da empresa ao Juízo da execução, de maneira a propiciar a futura satisfação do exeqüente, e (b) fazê-lo sem inviabilizar o exercício pela empresa- executada de sua atividade empresarial.

Caberá assim ao administrador primeiro conhecer a realidade da empresa, de seu negócio, apurar seu faturamento médio, suas perspectivas, apurar outras eventuais fontes de receita, enfim, fazer um diagnóstico da realidade econômica e financeira da empresa executada e com base nisto sugerir ao Juiz a melhor forma de realização da constrição, inclusive, sugerindo o percentual de incidência da penhora e precisando sua base de incidência. As variáveis são inúmeras, podendo a penhora incidir apenas sobre o faturamento, sobre o faturamento e outras receitas, sobre o faturamento descontado o custo das mercadorias vendidas, sobre o lucro, etc.. O percentual será maior ou menor a depender da base de incidência da penhora, se será considerado o valor bruto, com impostos, se outras receitas serão incluídas, se há condição de ser fixado percentual apenas sobre o lucro (situação mais desejável), etc.. Enfim, caberá ao administrador fazer sugestão de plano de constrição que melhor se afine à realidade da empresa e ao objetivo final de afetar dinheiro à execução. Nesse sentido, fez bem o legislador em não ter fixado percentuais ao tratar da penhora de faturamento, o que dependerá de cada situação concreta. Aliás, ronda na jurisprudência sobre a matéria um cabalístico percentual de $30 \%$ do faturamento, como limite à penhora de faturamento. Não se verifica, contudo, nenhuma base concreta e objetiva para fixação deste percentual.

A elaboração do plano de constrição pelo administrador trata-se de uma fase análoga a uma perícia judicial, sem, logicamente, os rigores deste ato processual. Por isso, é recomendável que a apresentação do plano de constrição ao Juiz fosse feita por profissional habilitado à matéria econômica ou contábil de confiança do Juízo. Cabe às partes a oportunidade de se manifestar sobre o plano apresentado e, se entenderem pertinente, nomear assistente técnico para acompanhar os trabalhos do administrador. Não há impedimento legal à apresentação do plano pelo representante da empresa-executada, se 
nomeado para a função, embora a imparcialidade da análise naturalmente possa ficar comprometida. Nada impede também que, por razões de custo, seja nomeado perito para a definição do plano a ser posteriormente executado pelo representante da empresa-executada na condição de administrador da penhora. ${ }^{300}$ De uma forma ou de outra, caberá ao Juiz a palavra final sobre os critérios a serem seguidos na realização da constrição judicial, com base nas informações constantes do plano de constrição, momento em que o Juiz determinará a lavratura do auto de penhora, com a precisa delimitação de seu objeto e nomeação do depositário/administrador.

Superada esta fase, caberá ao administrador da penhora tomar as providências necessárias para que a empresa-executada cumpra fielmente o plano traçado depositando em Juízo as quantias apuradas mês a mês. O parágrafo $3^{\circ}$. do art. 655 -A do Código de Processo Civil diz que caberá ao administrador entregar ao exeqüente as quantias recebidas. É evidente que tal só poderá ocorrer no momento que não houver qualquer óbice processual à satisfação do exeqüente; do contrário, os valores devem ser depositados em Juízo. A dúvida, contudo, se refere ao grau de ingerência que teria o administrador na condução dos negócios da empresa-executada, inclusive na determinação da transferência de determinado montante à ordem do Juízo da execução. O dispositivo legal não é claro na definição do alcance do poder do administrador da penhora. Segundo Humberto Theodoro Junior "o depositário exercerá uma intervenção parcial na gestão da empresa, durante o cumprimento do esquema judicial de pagamento. Tomará providências para recolher as importâncias deduzidas do caixa da empresa, ou descontadas da conta bancária de cobrança das duplicatas. Poderá, até mesmo, encarregar-se da cobrança dos títulos correspondentes ao percentual do faturamento penhorado. $\mathrm{O}$ esquema de pagamento poderá explicitar, caso a caso, a forma adequada de apropriação das parcelas estabelecidas". ${ }^{301}$ No nosso entender, como já dissemos, os poderes conferidos pelo Juiz ao administrador da penhora dependerá do que constar do plano de constrição, podendo ir da efetiva gestão da empresa, atividade intermediária relacionada ao

\footnotetext{
${ }^{300}$ Definido o plano de administração, pode haver situações em execuções de menor valor em que seja mais vantajoso, e mais viável economicamente, que o encargo de fazer o depósito do quantum mensal em juízo fique com o representante da empresa-executada, sob pena de o salário mensal do administrador judicial onerar excessivamente as partes. (Ver neste sentido interessante acórdão do extinto $1^{\circ}$. TACSP, RT 825/258, de 12 de novembro de 2003, cujo Relator foi o Juiz Cerqueira Leite).

301 cf. Humberto Theodoro Júnior (op. cit., p. 284).
} 
recebimento do percentual de faturamento objeto de penhora ou fiscalização da atuação dos administradores da empresa-executada no cumprimento do plano de constrição. Neste último caso, caberia ao administrador da penhora fiscalizar o cumprimento do plano de constrição pela empresa-executada, mediante o acesso a todas as informações necessárias para tanto, até porque terá ele de prestar contas mensais em Juízo, e solicitar ao representante-legal da empresa a tomada de eventuais providências para execução do plano. Caso se verifique resistências injustificadas ou atos de fraude à execução, caberá imediatamente ao administrador comunicar tais fatos ao Juiz da execução que além da aplicação das penalidades cabíveis ao executado poderá tomar outras providências, como a ampliação dos poderes de do administrador judicial no âmbito da empresa, bloqueio de quantias depositadas em contas bancárias, intimação de clientes da empresa a fazer pagamentos diretamente em Juízo, enfim, de todas as medidas constritivas disponíveis para fazer valer o plano de constrição do faturamento.

\subsubsection{Efeitos}

A penhora de faturamento impõe determinadas limitações à condução pela empresa-executada de sua atividade empresarial. Feita a penhora de faturamento, a administração da empresa-executada terá de observar o plano judicial e depositar parte de sua receita em Juízo. Trata-se de inequívoca limitação aos poderes de gozo que a empresa-executada tem sobre o seu estabelecimento empresarial.

A penhora de faturamento não implica na perda de poderes de disposição pela empresa-executada, mas qualquer ato que implique no comprometimento do montante destinado ao Juízo da execução, por força da penhora, será ineficaz perante o Juízo da execução. 


\subsection{Penhora de empresa e do estabelecimento empresarial}

\subsubsection{A empresa e o estabelecimento empresarial}

$\mathrm{O}$ art. 966 do Código Civil ao definir empresário nos remete ao conceito de empresa como "atividade econômica organizada para a produção ou circulação de bens ou de serviços". O estabelecimento por sua vez é definido pelo art. 1142 do referido diploma legal como "todo complexo de bens organizado, para exercício da empresa".

A empresa é então atividade que se vale do estabelecimento para se realizar, o qual compreende bens de diversas naturezas, corpóreos e incorpóreos, vinculados a uma destinação econômica única. ${ }^{302}$

Sendo assim, embora se tenha disseminado o termo "penhora de empresa" para designar o procedimento específico de penhora previsto no art. 677 e 678 do Código de Processo Civil, seria mais próprio designar tal procedimento como "penhora de estabelecimento empresarial", já que é este o objeto da penhora e não a atividade de empresa. É sobre esta universalidade de bens sobre a qual incide a penhora de estabelecimento. ${ }^{303}$

Evidentemente, sem um método de apreensão específico, não seria possível apreender judicialmente este conjunto de bens ligados entre si por uma única destinação. Nesse sentido, não é possível apreender o estabelecimento e depositá-lo em mãos de alguém para mera guarda. $\mathrm{O}$ estabelecimento para sua conservação e guarda exige ser administrado, tanto para conservar todos os bens componentes do estabelecimento, como também para manter tais bens destinados ao exercício da atividade econômica sobre a qual

\footnotetext{
302 cf. Priscila M.P. Corrêa da Fonseca e Raquel Sztajn (Código Civil Comentado, v. XI, p. 787). E também conforme Modesto Carvalhosa que entende abrangido no conceito de estabelecimento também "os serviços do empresário ou de seus empregados, reunidos por aquele com o propósito de exercer determinada atividade empresarial". (cf. Comentários ao Código Civil v. 13, p. 619).

${ }^{303}$ Priscila M.P. Corrêa da Fonseca e Raquel Sztajn expõem as divergências doutrinárias sobre a mais adequada qualificação do estabelecimento empresarial, se universalidade de fato ou de direito (Código Civil Comentado, v. XI, p. 783). Segundo Araken de Assis, trata-se de universalidade de direito (Manual da execução, p. 652).
} 
aqueles incidem. Como já ensinava José Frederico Marques à luz do Código de Processo Civil de 1939, "dupla é assim a finalidade da lei, nos preceitos citados: evitar que se fragmente ‘aquela reunião de coisas agrupadas em torno de uma finalidade comum' e ainda impedir que se paralise a empresa", devendo para tanto o administrador judicial tomar "o lugar do proprietário" e fazer "às vezes deste". 304

Trata-se de medida de gravosidade evidente, pois os donos e administradores da empresa e do seu respectivo estabelecimento são alijados da sua administração para que administrador nomeado pelo Juiz os assuma. Constitui-se em procedimento de intervenção judicial na empresa, em muito equiparável ao procedimento de falência da empresa, o qual também pressupõe "o afastamento do devedor de suas atividades", de modo à "preservar e otimizar a utilização produtiva dos bens, ativos e recursos produtivos, inclusive os intangíveis da empresa”.

Não se trata de uma penhora de fácil realização, pois suas conseqüências são imprevisíveis, já que o administrador judicial não conhece a fundo a empresa, não há controle sobre a reação de clientes e fornecedores da empresa à medida de tal gravidade, a conjuntura da economia pode afetar decisivamente o sucesso da penhora, etc.. Além disso, o Juiz não terá à sua disposição os instrumentos de que é dotado o processo de falência para realizar uma intervenção judicial eficaz.

Por isso, certamente trata-se de penhora excepcionalíssima, passível de realização apenas na ausência de outros bens penhoráveis e, ainda assim, caso o Juiz e as partes envolvidas no processo vislumbrem na realização deste procedimento utilidade à satisfação do crédito. Do contrário, se a empresa-executada tiver outros débitos e se verifique uma situação de insolvência, seria sem dúvida preferível pelos meios legais cabíveis a decretação da falência da empresa-executada, o âmbito institucional próprio para resolver débitos de empresa com patrimônio e capacidade empresarial insuficientes para solver suas obrigações, com a preservação o máximo possível da unidade empresarial produtiva no interesse não só de um credor, mas de toda a sociedade.

\footnotetext{
${ }^{304}$ Instituições de direito processual civil, vol. V, p. 213.
} 


\subsubsection{Modo de apreensão}

A apreensão judicial do estabelecimento se dá, como vimos acima, pela nomeação de administrador judicial que é investido do encargo de gerir a empresa em nome do Juízo, conservando sua atividade econômica incólume até o momento de se fazer a expropriação judicial do estabelecimento.

A penhora do estabelecimento empresarial é precedida pela apresentação de forma ou plano de administração pelo administrador da penhora, o qual poderá ser ajustado de comum acordo entre as partes e submetido à aprovação judicial. Aprovado o plano de administração pelo Juiz, deve-se lavrar o auto de penhora com a precisa delimitação do objeto da penhora e com assunção expressa do encargo pelo administrador. Nada impede, por outro lado, que este seja representante da própria empresa-executada, desde que concorde o exeqüente. Por não haver propriamente depósito pelo administrador, parte considerável da doutrina entende não ser cabível a ação de depósito contra o administrador, mas apenas a ação de prestação de contas. ${ }^{305}$

Caso o estabelecimento seja de titularidade de empresa concessionária ou autorizada a prestar serviço público, estabelece o art. 678, caput, do Código de Processo Civil, que a penhora poderá se fazer sobre renda, sobre determinados bens ou sobre todo o patrimônio, nomeando, como administrador, de preferência um dos seus diretores. Nos casos de tais empresas, ainda, incidindo sobre renda ou alguns bens, a satisfação do exeqüente não se pode dar por expropriação, mas apenas pela técnica do usufruto prevista no art. 716 em diante do Código de Processo Civil. ${ }^{306}$ Caso a penhora incida sobre todo o patrimônio ou todo o estabelecimento, destinado à prestação do serviço público, antes da adjudicação ou arrematação do estabelecimento, o poder público concedente da autorização ou da concessão deverá ser ouvido.

\footnotetext{
${ }^{305}$ Neste sentido Humberto Theodoro Junior (Processo de Execução e Cumprimento da Sentença, p. 290) e Pontes de Miranda (Comentários ao Código de Processo Civil, tomo XIII, p. 328).

${ }^{306} \mathrm{cf}$. Araken de Assis (Manual da Execução, p. 656).
} 


\subsubsection{Efeitos}

A penhora de estabelecimento acarreta a perda dos poderes de gozo pelo executado de seu estabelecimento empresarial. Não há perda do poder de disposição do estabelecimento, mas qualquer ato de disposição será considerado ineficaz perante o Juízo da execução. 


\section{CONCLUSÃO}

Concluímos, com a esperança de que ao menos consigamos contribuir com o debate sobre o tema proposto.

1. A jurisdição tem escopos a cumprir, de natureza jurídica, social, política, educacional e econômica. Para tanto, as sentenças e títulos executivos extrajudiciais de obrigações de pagar quantia devem ser atuados concretamente na realidade. $\mathrm{O}$ credor ou exeqüente deve ser satisfeito, recebendo a quantia consignada no título, seja para reparar um dano, para saldar um crédito, para fazer valer um dever legal, etc., enfim, a ele deve ser dado tutela jurisdicional plena.

2. Disto dependerá o funcionamento adequado da execução forçada, a técnica processual ou o sistema concebido pelo Legislador para atuar na realidade o comando abstrato contido na sentença ou no título executivo. Por este sistema, o Estado-Juiz por meio de seu poder coercitivo pratica atos de invasão da esfera patrimonial do devedor ou executado para, independentemente de sua vontade, expropriar bens componentes de seu patrimônio em benefício do credor.

3. O bom desempenho do sistema de execução forçada não interessa apenas às partes envolvidas no litígio, mas também à toda sociedade, pois, será a atuação do direito material na realidade concreta que dará aos membros da sociedade, indivíduos, empresas e governantes, os incentivos corretos para observar a Lei e os contratos.

4. A execução forçada, como instituição composta por órgãos jurisdicionais e leis, tem repercussões sensíveis na atividade econômica do país, na medida em que seu funcionamento interfere nos custos de transação dos agentes econômicos. Quanto melhor for seu funcionamento, propiciando a recomposição patrimonial dos credores de forma ágil e consistente, menores serão os custos de transação, o que contribui com o aumento de negócios entre os agentes econômicos, traz mais eficiência à economia e maior desenvolvimento econômico ao país. 
5. Nesse sentido, cada vez mais juristas e economistas se conscientizam de que a atuação jurisdicional impacta a atividade econômica. As recentes reformas processuais, com o objetivo de tornar a execução forçada mais célere e efetiva, são permeadas por esta constatação.

6. Ainda não se pode dizer que tais reformas processuais já produziram todos os resultados almejados, embora signifiquem inegável avanço. Ao lado de alterações legislativas, não se pode negar que mudanças mais significativas devam passar por um melhor aparelhamento do Poder Judiciário e por mudanças culturais na forma de atuação de Juízes, advogados e partes nos processos de execução. O manejo da técnica processual não deve se afastar de sua finalidade de servir de instrumento de atuação do direito material. É longo o processo de maturação até que possamos considerar nosso sistema de execução forçada, célere, justo e eficiente.

7. A penhora é instituto processual critico para o bom funcionamento da execução forçada. Trata-se do primeiro ato propriamente executivo da execução forçada e tem a função de apreender bens do executado que sejam suficientes à satisfação do crédito do exeqüente, afetando-os ao Juízo da execução.

8. A penhora pode incidir sobre quaisquer bens do executado, com exceção daqueles declarados por Lei impenhoráveis. A penhora deve (a) ser determinada e controlada pelo Juiz, com o apoio se necessário do Oficial de Justiça, (b) incidir sobre bens em valor suficiente à satisfação do crédito e neste limite deve ser feita e (c) implicar na apreensão e, nos casos cabíveis, depósito dos bens, mediante formalização de um auto de penhora.

9. Não cabe ao legislador definir previamente todos os bens passíveis de penhora. O rol do artigo 655 do Código de Processo Civil é meramente exemplificativo. Não havendo definição prévia pelo Legislador de procedimento específico para a realização da penhora de determinado bem, pode a apreensão ser efetuada por método que melhor se adapte às características do bem. 
10. A penhora depende para sua concretização da tomada de uma série de providências práticas de apreensão e afetação do bem ao juízo da execução. Trata-se de ato que incide sobre a realidade concreta e com suas vicissitudes se confronta. $\mathrm{O}$ método ou a forma de apreensão deve ser adaptado às características do objeto que se pretende apreender. A análise histórica do instituto evidencia como as formas de apreensão de bens foram se diversificando e se sofisticando à medida que a realidade econômica e social também se tornava mais complexa.

11. As providências de apreensão do bem de titularidade do executado se destinam a afetá-lo juridicamente aos fins da execução, retirando do executado o exercício de plenos poderes sobre o bem. Trata-se de retirar do executado o poder de dispor eficazmente do bem em prejuízo do juízo da execução.

12. A penhora de bens corpóreos se dá pela apreensão física e depósito em mão de depositário responsável por sua guarda e conservação. A apreensão será ficta no caso do bem não ser retirado do poder do executado, o qual figurará como depositário da penhora. A apreensão será real nos casos em que o bem for retirado do poder do executado, cabendo a terceiro exercer o encargo de depositário.

13. A penhora de bens incorpóreos se dá por ordens judiciais ao executado e a terceiros para que sejam praticados atos que propiciem a afetação do bem ao juízo da execução e sua conservação até o momento da expropriação. O sistema-base para a penhora de bens incorpóreos vem estabelecido nos artigos 671 a 676 do Código de Processo Civil, que trata da penhora de "créditos e outros direitos patrimoniais". A penhora de empresa e estabelecimento empresarial, do art. 677 a 678 do Código de Processo Civil, também é modalidade de penhora de bem incorpóreo, de regime particular, por envolver administração de universalidade.

14. As providências previstas no artigo 671 do Código de Processo Civil que objetivam tornar indisponível o direito de crédito do executado são consistentes com 
a natureza do bem que se pretende apreender. Contudo, como no caso de penhora de "crédito", o Juiz não tem meios de garantir a observância da ordem de indisponibilidade, eventual ato de disposição do "crédito" será considerado ineficaz perante o juízo da execução.

15. É cabível, para segura afetação do bem ao juízo da execução, a ordem judicial de indisponibilidade do direito sobre o bem incorpóreo, de alto grau de liquidez e que seja passível de fácil e rápida circulação na economia. É o caso, por exemplo, do dinheiro depositado em conta corrente bancária e da "aplicação em instituição financeira".

16. $\mathrm{O}$ ato de penhora acarreta efeitos processuais e materiais. Os efeitos processuais, ocorrentes em quaisquer penhoras são os seguintes: (a) há uma individualização do bem passível de responsabilidade executiva; (b) há a constituição de uma garantia do juízo da execução a ser conservada até a futura expropriação; (c) há a constituição de um direito de preferência em favor do exeqüente e (d) desencadeia-se a técnica expropriativa.

17. Os efeitos materiais vão variar conforme for o método de apreensão e a natureza do bem. Qualquer ato de eventual disposição de bem penhorado é ineficaz perante o juízo da execução.

18. Quanto aos demais efeitos materiais decorrentes da penhora de bens corpóreos: (a) na apreensão real, há perda da posse direta e dos poderes de uso e gozo pelo executado, e (b) na apreensão ficta, não há perda da posse direta, há limitação ao poder de uso e, de acordo com o entendimento da doutrina majoritária, há perda dos poderes de gozo. No nosso entendimento, não é sempre que o executado perde os poderes de gozo sobre o bem penhorado. Na apreensão ficta e na apreensão de bens incorpóreos, a perda dos poderes de gozo dependerá do método de apreensão do bem principal abranger logicamente a apreensão dos frutos ou, se não for este o caso, de haver expressa penhora sobre os frutos.

19. Na penhora de bens corpóreos, deve haver lavratura de auto de penhora, depósito e avaliação do bem. Na penhora de bens incorpóreos, não há necessidade de 
lavratura do auto de penhora de "crédito". Há bens incorpóreos, especialmente os bens escriturais, que são passíveis de guarda e custódia por terceiros, o que caracteriza o depósito judicial. Para estes bens deve ser lavrado auto de penhora, depósito e avaliação, com indicação do nome da instituição depositária do bem. Para outros bens incorpóreos, impassíveis de depósito, basta a lavratura do auto de penhora e avaliação.

20. O regime dos atos atentatórios à dignidade da Justiça dos artigos 600 e 601 do Código de Processo Civil tem caráter coercitivo e pode contribuir com a consecução pelo executado dos chamados deveres instrumentais da execução.

21. Entendemos que a prisão do depositário infiel é passível de ser decretada sempre que o depositário, que tenha assumido expressamente o seu encargo, aja dolosamente no sentido de não restituir o bem depositado ao juízo da execução.

22. A ordem de preferência do art. 655 do Código de Processo Civil não é absoluta, podendo o Juiz preferir a penhora sobre bens mais líquidos a outros bens, ainda que estes tenham, em tese, preferência na ordem legal. Na ordem legal de preferência, títulos da dívida pública com cotação em mercados e títulos e valores mobiliários com cotação em mercado deveriam ser colocados em segundo lugar, logo após o "dinheiro" e a "aplicação em instituição financeira". Pela sua excepcionalidade, a penhora de percentual de faturamento de empresa deveria ser colocado em último lugar na ordem legal de preferência. A penhora de percentual de faturamento de empresa devedora, de todo modo, conforme reiterada jurisprudência de Superior Tribunal de Justiça, só pode ocorrer caso não existam outros bens suficientes passíveis de penhora. $\mathrm{O}$ mesmo raciocínio deve ser feito em relação à penhora de estabelecimento empresarial e à cota social de sociedade limitada, pelo embaraço que tais espécies de penhora podem acarretar à continuidade da atividade empresarial.

23. A penhora de dinheiro depositado em conta bancária, de “aplicação em instituição financeira”, de valores mobiliários com cotação em mercado e títulos da dívida pública com cotação em mercado, se faz por ordem de indisponibilidade dos bens; em razão da alta liquidez de tais bens e facilidade de circulação em mercado. 
24. A penhora de "crédito" se faz por notificações ao executado e ao devedor do executado (debitor debitoris) com o fito de impedir a disponibilidade e circulação do "crédito".

25. As cotas de sociedades limitadas e as ações de companhia fechada por não serem passíveis de negociação em mercado organizado e por serem, em regra, ativos menos líquidos prescindem de ordem de indisponibilidade para serem apreendidos. Trata-se, contudo, de penhora passível de averbação/registro para dar-se conhecimento do ato de penhora a terceiros.

26. A penhora de imóvel se dá por apreensão ficta, por termo nos autos, sendo fundamental para que o ato de penhora tenha eficácia erga omnes o registro no Cartório de Imóveis.

27. A penhora de faturamento de empresa e do estabelecimento empresarial se dá por regime de administração, conduzido por administrador judicial, mediante prévia aprovação pelo Juiz de plano de constrição judicial.

28. Por fim, de lege ferenda, sugere-se a alteração do Código de Processo Civil para contemplar rito de penhora de bens imateriais e incorpóreos, adaptado à realidade econômica e social atual, em substituição ao defasado rito da penhora de "créditos e outros direitos patrimoniais". 


\section{REFERÊNCIAS BIBLIOGRÁFICAS}

ABRÃO, Carlos Henrique. "Depositário judicial na penhora do faturamento". In: Revista Dialética de Direito Tributário 59/07.

Tributário 59/06. . "A excepcionalidade da penhora". In: Revista Dialética de Direito Tributário 32/21. . "Penhora de títulos públicos". In Revista Dialética de Direito Tributário 40/07.

. Penhora de Cotas de Sociedade de Responsabilidade Limitada. $2^{\text {a }}$. edição. São Paulo: Revista dos Tribunais, 1991.

ABRÃO, Nelson. Direito Bancário. 11ª . ed. São Paulo: Saraiva, 2008.

ALMEIDA, Cândido Mendes de. Código Philippino. Rio de Janeiro: 1870, Typ. do Instituto Philomatico.

. Auxiliar jurídico - appendice à décima quarta edição do Código Philippino vols. I e II. Rio de Janeiro: Typ. do Instituto Philomatico, 1870. Edição "fac-simile" da Fundação Calouste Gulbenkian.

ALMEIDA, Amador Paes de. Teoria e prática dos títulos de crédito. $27^{\mathrm{a}}$ ed. São Paulo: Saraiva, 2008.

ALVES, Jones Figueiredo; DELGADO, Mario Luiz. Novo Código Civil confrontado. $3^{\mathrm{a}}$ ed. São Paulo: Método, 2003.

AZEVEDO, Álvaro Villaça. Prisão civil por dívida. São Paulo: Revista dos Tribunais, 1993.

ALVIM, Arruda. "A Natureza jurídica da impugnação na Lei 11.232/2005 - A impugnação do devedor instaura uma ação incidental proporcionando o exercício do contraditório pelo credor; exige decisão, que ficará revestida pela autoridade de coisa julgada". In: WAMBIER, Teresa Arruda Alvim (Coord.). Aspectos polêmicos da nova execução-3. São Paulo: Revista dos Tribunais, 2006.

ARZUA, Guido. Posse - o direito e o processo. São Paulo: Revista dos Tribunais, 1960.

ASSIS, Araken de. Manual da execução. 11 a . Edição. São Paulo: Revista dos Tribunais, 2007. . Cumprimento da sentença. Rio de Janeiro: Forense, 2006.

AITH, Márcio. "O impacto do Judiciário nas atividades das instituições financeiras". In: PINHEIRO, Armando Castelar. (Org.). Judiciário e Economia no Brasil. São Paulo: Sumaré, 2000.

AZEVEDO, Luiz Carlos. Introdução à história do direito. São Paulo: Revista dos Tribunais, 2005.

. Da penhora. Osasco: FIEO: Resenha Tributária, 1994. 
AZEVEDO, Luiz Carlos e CRUZ E TUCCI, José Rogério. Lições de história do processo civil romano. São Paulo: Revista dos Tribunais, 1996.

BAPTISTA DA SILVA, Ovídio A. A ação de imissão na posse. $3^{\mathrm{a}}$. ed. São Paulo: Revista dos Tribunais, 2001. 2007. Jurisdição e execução na tradição romano-canônica. $3^{\mathrm{a}}$. ed. Rio de Janeiro: Forense,

BAUMOHL, Denise Inês Kram. A Nova Execução Civil - A Desestruturação do Processo de Execução. São Paulo: Atlas, 2006.

BEDAQUE, José Roberto dos Santos. Efetividade do processo e técnica processual. São Paulo: Malheiros, 2006.

. Direito e processo. $3^{\text {a }}$. ed. São Paulo: Malheiros, 2003.

. "Algumas considerações sobre o cumprimento da sentença condenatória". Revista do Advogado, $n^{\circ}$ 85. Associação dos Advogados de São Paulo. São Paulo: 2006.

"Nulidade processual e instrumentalidade do processo". In: Revista de Processo, 60/31. São Paulo: Revista dos Tribunais.

BITTAR, Eduardo C.B. Metodologia da pesquisa jurídica. 6 ${ }^{\text {a }}$.ed. São Paulo: Saraiva, 2007.

BLANCHARD, Olivier. Macroeconomia: teoria política e econômica. Tradução de Ricardo Inojosa. Rio de Janeiro: Campus, 1999.

BONE, Roberto G. The economics of civil procedure. Nova York: Thomson West, 2003.

BONSIGNORI, Ângelo. L'esecuzione forzata. $3^{\mathrm{a}}$. ed.. Torino: G. Giappichelli Editore, 1996.

BORBA, José Edwaldo Tavares. Direito societário. 11ª ed. Rio de Janeiro: Renovar, 2008.

BRASIL, Francisco de Paula Eugênio Jardim de Souza. Títulos de crédito: o novo Código Civil - questões relativas aos títulos eletrônicos e do agronegócio. $1^{\mathrm{a}}$ ed. Rio de Janeiro: Forense, 2006.

BUENO, Cassio Scarpinella. A nova etapa da reforma do Código de Processo Civil. v. 1. São Paulo: Saraiva, 2006.

BULGARELLI, Waldirio. Direito comercial. 10a ed. São Paulo: Atlas, 1993. . Contratos mercantis - direito comercial IV. $1^{\text {a }}$ ed. São Paulo: Atlas, 1979.

CAPPELlETTI, Mauro. Processo, Ideologias e Sociedade, volume I. Trad. Elicio de Cresci Sobrinho. Porto Alegre: Sergio Antonio Fabris Editor, 2008.

CAPPELLETTI, Mauro e GARTH, Bryant. Acesso à Justiça. Trad. Ellen Gracie Northfleet. Porto Alegre: Sergio Antonio Fabris Editor, 1988.

CAHALI, Yussef Said. Fraude contra credores. 3a. ed. São Paulo: Revista dos Tribunais, 2002. 
CARMONA, Carlos Alberto. "Novidades sobre a execução civil: observações sobre a Lei 11.232/2005". In BOTTINI, Pierpaolo e RENAULT, Sergio. A Nova Execução de Títulos Judiciais: Comentários à Lei 11.232/2005 (Coord.). São Paulo: Saraiva, 2006.

CARNEIRO, Athos Gusmão. Cumprimento da Sentença Civil. Rio de Janeiro: Forense, 2007.

CARvalhoSA, Modesto. Comentários ao Código Civil - volume 13. $2^{\mathrm{a}}$ ed. São Paulo: Saraiva, 2005.

. Comentários à lei das sociedades anônimas, v. 1. São Paulo: Saraiva, 1997.

CARVALHOSA, Modesto e EIZIRIK, Nelson. A nova lei das S/A. São Paulo: Saraiva, 2002.

CASTRO, Artur Anselmo de. Direito processual civil declaratório, vol III. Coimbra: Almedina, 1982.

CHIOVENDA, Giuseppe. Instituições de Direito Processual Civil. $2^{\mathrm{a}}$ ed.. São Paulo: Ed. Bookseller, 2000.

CINTRA, Antônio Carlos de Araújo; GRINOVER, Ada Pelegrini e DINAMARCO, Cândido Rangel. Teoria Geral do Processo. 20ª ed. São Paulo: Malheiros, 2001.

CLERMONT, Kevin M. Principles of civil procedure. Thomsom West, 2005.

COASE, Ronald. "The Problem of Social Cost". In: Jornal of Law and Economics, n. 3, 1960.

COELHO, Fábio Ulhoa. Manual de direito comercial - direito de empresa. $20^{\mathrm{a}}$ ed. São Paulo: Saraiva, 2008.

. Curso de direito civil - volume 4. São Paulo: Saraiva, 2006.

."Penhorabilidade de cotas sociais". In: Revista de Direito Mercantil 82/95.

COOTER, Robert e ULEN, Thomas. Law and Economics. Pearson Education, 2004.

COSTA, Mário Julio de Almeida. História do Direito Português. Coimbra: Livraria Almedina, $3^{\text {a }}$. Edição, 1996.

COUTURE, Eduardo. Fundamentos do direito processual civil. Tradução de Rubens Gomes de Souza. São Paulo: Saraiva, 1946.

COVELlO, Sergio Carlos. Contratos bancários. $4^{\mathrm{a}}$ ed. São Paulo: Universitária de Direito, 2001. O sigilo bancário. São Paulo: Ed. LEUD 2.001.

CRUZ E TUCCI, José Rogério. "Garantia da prestação jurisdicional sem dilações indevidas como corolário do devido processo legal”. In: Revista de Processo 66. São Paulo: Revista dos Tribunais. 
DAKOLIAS, Maria. "World performance around the world: a comparative perspective". In: World Bank technical paper, n. 430. World Bank, 1999.

DE SANTO, Victor. Procesos de Ejecución. Buenos Aires: Editorial Universidad, 2003.

DIAS, Eduardo Rocha. "Penhora de faturamento e princípio da proporcionalidade". In Revista Dialética de Direito Tributário: 38/41.

DINAMARCO, Cândido Rangel. Instituições de direito processual civil. v. IV. São Paulo: Malheiros, 2004. . "Tutela Jurisdicional". In: Fundamentos do processo civil moderno, tomo II. $5^{\mathrm{a}}$. ed.. São Paulo: Malheiros, 2002. . Instituições de direito processual, v. II. São Paulo: Malheiros, 2001.

— A instrumentalidade do processo. $8^{\text {a }}$. ed. São Paulo: Malheiros, 1996. Execução Civil. $4^{\mathrm{a}}$. ed. São Paulo: Ed. Malheiros, 1993.

DINIZ, Maria Helena. Curso de direito civil brasileiro $-4^{o}$. volume. $10^{\mathrm{a}}$. ed. São Paulo: Saraiva, 1995. . Curso de direito civil brasileiro - $3^{o}$ volume. $8^{a}$ ed. São Paulo: Saraiva, 1993.

DJANKOV, Simenon; LA PORTA, Rafael; LOPEZ-DE-SILANES, Florenzio et. al. SHLEIFER, A. 2002. Courts: the lex mundi project. National Bureau of Economic Research (NBER), Cambrigde, Abril de 2002, www.nber.org/papers/w8890.

ECO, Umberto. Como se faz uma tese. Tradução Brasileira. Editora Perspectiva, 19a . edição.

EIZIRIK, Nelson; GAAL, Ariadna B.; PARENTE, Flávia; HENRIQUES, Marcus de Freitas. Mercado de capitais - regime jurídico. $2^{\mathrm{a}}$ ed. Rio de Janeiro: Renovar, 2008.

FACHADA, Pedro; FIGUEIREDO, Luiz Fernando e LUNDBERG, Eduardo. "Sistema Judicial e Mercado de Crédito no Brasil". In: Notas Técnicas do Banco Central do Brasil, n. 35. Banco Central do Brasil, maio de 2003: http://www.bcb.gov.Br/pecNotasTecnicas/Port/2003nt35sistemajudicialmercadocredbrasilp.pd f.

FALCÓN, Enrique M. Juicio Ejecutivo. Tomo I, volumes A e B. Buenos Aires: RubinzalCulzione Editores.

FARIA, Antônio Bento de. Código Commercial Brasileiro Anotado. $2^{\text {a }}$. ed. Rio de Janeiro: Editor Jacintho Ribeiro dos Santos, 1912.

FERNANDES, Odmir; CHIMENTI, Ricardo Cunha e ABRÃO, Carlos Henrique, et ali. Lei de execução fiscal comentada e anotada: lei 6.80, de 22.09.1980, doutrina, prática, jurisprudência. $4^{\text {a }}$ ed. São Paulo: Revista dos Tribunais, 2002.

FERRAZ JR., Tercio Sampaio. Introdução ao estudo do direito - técnica, decisão, dominação. São Paulo: Atlas, 1988. 
FERREIRA, Fernando Amâncio. Curso de processo de execução. 9a ed. Coimbra: Almedina, 2006.

FONSECA, Priscila M. P. Corrêa da e SZTAJN, Raquel. Código civil comentado - volume XI. São Paulo: Atlas, 2008.

FREITAS, José Lebre de. A acção executiva. 4 ${ }^{\mathrm{a}}$. ed. Coimbra Editora, 2004.

FREITAS, Ricardo de Santos. Natureza jurídica dos fundos de investimento. São Paulo: Quartier Latin, 2006.

FRIEDENTHAL, Jack H.; KANE, Mary Kay e MILLER, Arthur R. Civil Procedure. 4a. ed., Thomson West.

GOLDSCHMIDT, Guilherme. A penhora on line do direito processual brasileiro. Porto Alegre: Livraria do Advogado, 2008.

GRAU, Eros Roberto. O direito posto e o direito pressuposto. São Paulo: Malheiros, 1996.

GRINOVER, Ada Pellegrini. "Cumprimento da Sentença". In: BRUSCHI, Gilberto Gomes (coord.). Execução Civil e cumprimento da sentença. São Paulo: Método, 2006.

"Deformalização do Processo e Deformalização das Controvérsias". Revista de Processo, 46/60. São Paulo: Revista dos Tribunais.

GUIMARÃES, Leonardo. "Questões controvertidas no processo de execução". In: Revista de Direito Mercantil 122/65.

HOUAISS, Antônio e VILLAR, Mauro de Salles. Dicionário Houaiss da Língua Portuguesa. Rio de Janeiro: Objetiva: 2001.

LEAL, Murilo Zanetti. A transferência involuntária de quotas nas sociedades limitadas. São Paulo: Revista dos Tribunais, 2002.

LIEBMAN, Enrico Tullio. Processo de execução. 4a . ed. São Paulo: Saraiva, 1980.

LUCON, Paulo Henrique dos Santos. "Títulos Executivos e multa de 10\%" in Execução Civil: Estudos em Homenagem ao Professor Humberto Theodoro Júnior, coord. Ernane Fidélis dos Santos e o.. São Paulo: Ed. Revista dos Tribunais.

. "Fraude de execução, responsabilidade processual civil e registro da Penhora". In: Revista de Processo, 98/161. Ed. Revista dos Tribunais.

MARQUES, José Frederico. Instituições de direito processual civil, vol. V. Rio de Janeiro: Forense, 1960.

MARMITT, Arnaldo. A Penhora - Doutrina e Jurisprudência. Aide, 1992. 
MARTINS, Fran. Títulos de crédito, I. 10ª ed. Rio de Janeiro: Forense, 1995.

. Contratos e obrigações comerciais. 13 $3^{\mathrm{a}} \mathrm{ed}$. Rio de Janeiro: Forense, 1995.

MESQUITA, José Ignácio Botelho de. "Metamorfose dos embargos". In: Revista do Advogado, $\mathrm{n}^{\circ}$ 85. Associação dos Advogados de São Paulo. São Paulo: 2006.

. Da ação civil. São Paulo, 1973.

MERCURO, Nicholas e MEDEMA, Steven G. Economics and Law: from Posner to postmodernism. Princenton: Princenton University, 1997.

NEVES, Celso. Comentários ao Código de Processo Civil, vol VII: arts. 646 a 795. 2a ${ }^{\mathrm{a}}$ Ed.: Rio de Janeiro: Forense, 1977.

MEZZAROBA, Orides e MONTEIRO, Cláudia Servilha. Manual de Metodologia da Pesquisa no Direito. $3^{\text {a }}$.ed. São Paulo: Saraiva, 2006.

MIRANDA, Pontes de. Comentários ao Código de Processo Civil, Tomo XIII. $2^{\mathrm{a}}$. ed. Revista Forense, 1961.

História e prática do arresto ou embargo. Campinas: Bookseller, 1999.

MONTEIRO, Washington de Barros. Curso de direito civil $-4^{o}$ Volume. $27^{\mathrm{a}}$ ed. São Paulo: Saraiva, 1994.

. Curso de direito civil - $5^{\circ}$ Volume. $20^{\mathrm{a}}$ ed. São Paulo: Saraiva, 1985.

MOREIRA, José Carlos Barbosa. O novo processo civil brasileiro. $25^{\text {a }}$. ed. Rio de Janeiro: Ed.Forense, 2007.

. "Dois cientistas políticos, três economistas e a justiça brasileira". In: Temas de direito processual: nona série. São Paulo: Saraiva, 2007.

. "O futuro da Justiça: alguns mitos". In: Temas de direito processual: oitava série. São Paulo: Saraiva, 2004.

. "Por um processo socialmente efetivo". In: Temas de direito processual: oitava série. São Paulo: Saraiva, 2004.

"Notas sobre alguns aspectos do processo (civil e penal) nos países anglosaxônicos”. In: Temas de direito processual: sétima série. São Paulo: Saraiva, 2001.

"A influência do direito processual civil alemão em Portugal e no Brasil". In: Temas de direito processual: quinta série. São Paulo: Saraiva, 1994.

. "Notas sobre o problema da efetividade do processo". In: Temas de direito processual: terceira série. São Paulo: Saraiva, 1984.

MOREIRA, Alberto Camiña. "Ato atentatório à dignidade da justiça. Não nomeação de bens à penhora”. In: SHIMURA, Sergio e WAMBIER, Teresa Arruda Alvim. Processo de Execução, v.2. São Paulo: Revista dos Tribunais, 2001.

MUSCARI, Marco Antônio Botto. Efetividade da Execução por Quantia Certa contra Devedor Solvente. Tese de Doutoramento. Orientador Prof. Luiz Carlos de Azevedo USP, 2003. 
NEGRÃO, Theotonio. Código de Processo Civil e Legislação Processual em Vigor. $39^{\mathrm{a}}$ ed.. São Paulo: Saraiva, 2007.

NORTH, Douglass C. Institutions, Institutional Change and Economic Performance. Cambridge University Press, 1990.

OLIVEIRA, Carlos Alberto Alvaro de. Do Formalismo no Processo Civil. 2a . Ed.. São Paulo: Ed. Saraiva, 2003.

OLIVEIRA, Marcos Cavalcante de. Moeda, juros e instituições financeiras. $2^{\mathrm{a}}$ ed. Rio Janeiro: Forense, 2009.

PATRÍCIO, José Simões. Regime jurídico do euro. Coimbra: Coimbra Editora, 1998.

PINHEIRO, Armando Castelar. "Magistrados, Judiciário e Economia no Brasil". In: ZYLBERSZTAJN, Décio e SZTAJN, Raquel (Org.). Direito \& Economia - Análise Econômica do Direito e das Organizações. Rio de Janeiro: Elsevier, 2005.

"O Componente Judicial dos Spreads Bancários" in Relatório Banco Central, Economia Bancária e Crédito: avaliação de quatro anos do projeto Juros e Spread Bancário, p. 34-44. Banco Central do Brasil, 2003: www.bcb.gov.br/ftp/releconomia_bancaria_credito.pdf.

“Impacto sobre o crescimento: uma análise conceitual”. In: PINHEIRO, Armando

Castelar. (Org). Judiciário e Economia no Brasil. São Paulo: Sumaré. 2000.

"O Judiciário e a economia: evidência empírica para o caso brasileiro". In:

PINHEIRO, Armando Castelar. (Org.). Judiciário e Economia no Brasil. São Paulo: Sumaré, 2000.

PINHEIRO, Armando Castelar e SADDI, Jairo. Direito, Economia e Mercados. Rio de Janeiro: Elsevier. 2005.

PIRES, José Paulo Leal Ferreira. Títulos de crédito: letra de câmbio, nota promissória, cheque, duplicata, títulos da dívida pública e exceção de pré-executividade. $2^{\mathrm{a}}$ ed. São Paulo: Malheiros, 2001.

REDONDO, Bruno Garcia; LOJO, Mário Vitor Suarez. Penhora: exposição sistemática do procedimento, de acordo com as Leis 11.232/2005 e 11.382/2006, bens passíveis de penhora, impenhorabilidade absoluta, relativa e o bem de residência. São Paulo: Método, 2007.

RIBEIRO, Ivan. Robin Hood versus King John. Como os Juizes locais decidem casos no Brasil?. SSRN, 13 de setembro de 2006: http://ssrn.com/abstract961425.

ROLLO, Arthur Luis Mendonça. "Fiel depositário dos bens, deveres, conseqüências e possibilidade de prisão civil". In: BRUSCHI, Gilberto Gomes (coord.). Execução Civil e cumprimento da sentença. São Paulo: Método, 2006.

SADDI, Jairo. Crédito e Judiciário no Brasil: uma análise de direito \& economia. São Paulo: Quartier Latin, 2007. 
SALLES, Carlos Alberto de. Execução judicial em matéria ambiental. São Paulo: Revista dos Tribunais, 1998.

SHIRLEY, Mary M. “Institutions and Development”. In: MÉNARD, C. e SHIRLEY, Mary M (eds). Handbook of New Institutional Economics. Springer, 2005.

STIGLER, George. "Law or Economics?", Journal of Law and Economics, vol XXXV:455468, 1992.

SZTAJN, Raquel; ZYLBERSZTAJN, Décio e MUELLER, Bernardo. "Economia dos direitos de propriedade". In: ZYLBERSZTAJN, Décio e SZTAJN, Raquel e. (Org.). Direito \& Economia - Análise Econômica do Direito e das Organizações. Rio de Janeiro: Elsevier, 2005.

TALAMINI, Eduardo. “Ainda sobre a prisão como 'execução indireta': a criminalização da desobediência a ordens judiciais". In.: SHIMURA, Sergio e WAMBIER, Teresa Arruda Alvim. Processo de Execução, v.2. São Paulo: Revista dos Tribunais, 2001.

TAVARES, J. Edvaldo. Legislação processual remissiva. Livraria Freitas Bastos, 1960.

THEODORO JÚNIOR, Humberto. Processo de execução e cumprimento da sentença. $25^{\mathrm{a}}$. ed. São Paulo: LEUD, 2.008. . As novas reformas do Código de Processo Civil. Rio de Janeiro: Forense, 2006. . "As nulidades no Código de Processo Civil" in Revista de Processo, 30/38. São Paulo: Revista dos Tribunais.

TURCZYN, Sidnei. O sistema financeiro nacional e a regulação bancária. São Paulo: Revista dos Tribunais, 2005.

VERÇOZA, Haroldo Malheiros Duclerc. "Penhora de dinheiro em banco". Revista de Direito Mercantil 114/170.

. "O conceito de reservas bancárias e as características do mútuo e do depósito bancários". In Revista de Direito Mercantil 110/207.

VILAR, Willard de Castro. "Penhora das cotas de sociedade de responsabilidade limitada". In Revista de Direito Mercantil 25/31.

WALD, Arnoldo. Direito Civil: contratos em espécie, vol. 3. 18 a .ed. São Paulo: Saraiva, 2009.

WAMBIER, Luis Rodrigues, WAMBIER, Teresa Arruda Alvim e MEDINA, José Miguel Garcia. Breves Comentários à Nova Sistemática Processual Civil 2. São Paulo: Revista dos Tribunais, 2006.

WATANABE, Kazuo. Da Cognição no Processo Civil. $3^{\mathrm{a}}$. ed, São Paulo: DPJ Editora, 2005. 
. “Acesso à Justiça e Sociedade Moderna". In: GRINOVER, Ada Pellegrini; DINAMARCO, Cândido Rangel e WATANABE, Kazuo (Coord). Participação e processo, São Paulo: Revista dos Tribunais, 1998.

WILLIAMSON, Oliver. "Por quê Direito, Economia e Organizações". In: ZYLBERSZTAJN, Décio e SZTAJN, Raquel (Org.). Direito \& Economia - Análise Econômica do Direito e das Organizações. Rio de Janeiro: Elsevier, 2005.

YARSHELL, Flávio Luiz. Tutela jurisdicional. 2a . ed., São Paulo: DPJ Editora, 2006. "Alguns apontamentos sobre a chamada penhora on line - Parte II", Periódico Carta Forense, 2005.

. "Alguns apontamentos sobre a chamada penhora on line - Parte I", Periódico Carta Forense, 2005.

. "Tutela mandamental nas obrigações de pagamento de quantia". In: Revista da Procuradoria Geral do Estado de São Paulo, n. especial, p. 269-79, 2003.

. "A execução e a efetividade do processo em relação à Fazenda", p. 212-222 In: SUNDFELD, Carlos Ari e BUENO, Cássio Scarpinella (Coord). Direito Processual Público: a fazenda pública em juízo. São Paulo: Malheiros, 2003. . "Efetividade do processo de execução e remédios com efeito suspensivo". p. 381-392

In: SHIMURA, Sergio e WAMBIER, Teresa Arruda Alvim (Coord). Processo de execução. São Paulo: Revista dos Tribunais, 2001.

. Tutela jurisdicional específica nas obrigações de declaração de vontade. São Paulo: Ed. Malheiros, 1993

YARSHELL, Flávio Luiz e BONÍCIO, Marcelo José Magalhães. Execução civil: novos perfis. São Paulo: RCS Editora, 2006.

ZYLBERSZTAJN, Décio e SZTAJN, Raquel. "Análise Econômica do Direito e das Organizações”. In: ZYLBERSZTAJN, Décio e SZTAJN, Raquel (Org.). Direito \& Economia - Análise Econômica do Direito e das Organizações. Rio de Janeiro: Elsevier, 2005. 


\section{OUTRAS REFERÊNCIAS}

Caderno sobre regras de legislação-levantamento dos ativos registrados na CETIP. CETIP: http://www.cetip.com.br, última atualização em 02/05/2002.

Caderno: Os serviços de custódia $e$ de ações escriturais. CVM: http://www.cvm.gov.br/port/protinv/caderno2.asp.

Relatório de Economia Bancária e Crédito, 2007. Banco Central do Brasil: http://www.bcb.gov.br/PEC/Depep/Spread/relatorio_economia_bancaria_credito2007.pd f. 